\title{
Ground-Water Resources in Southern Oahu, Hawaii
}

By F. N. VISHER and J. F. MINK

GEOLOGICAL SURVEY WATER-SUPPLY PAPER 1778

Prepared in cooperation with the State of Hawaii, Department of Land and Natural Resources, Division of Water and Land Development

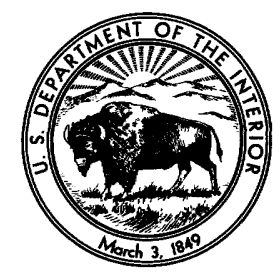




\section{UNITED STATES DEPARTMENT OF THE INTERIOR}

STEWART L. UDALL, Secretary

\section{GEOLOGIGAL SURVEY}

Thomas B. Nolan, Director 


\section{CONTENTS}

Abstract--.-

Introduction .....

Purpose and scope.

Location and extent of area.

Previous investigations.

Personnel and acknowledgments

Geography _............. 5

Surface features and drainage.

Climate ............... 6

Airmass circulation

Rainfall

Development. .

Geology

Geologic history

Shield volcanoes...

Sedimentation

Character of the water-bearing rocks

. Lavas_._.

Dikes

Pyroclastic rocks _.

Soils

Ground water....... 17

Modes of occurrence. 18

High-level ground water.

Basal ground water.

The fresh-water lens. 19

Transition between fresh and salt water...... 20

Development of fresh water.... 29

Basal ground water in southern Oahu

Extent and character of the basal aquifer._. 31

Source of water

Movement of the basal water. 34

Discharge . . .

Pearl Harbor springs_...

Description of major springs

Kalauao Springs

Waiau Springs

Waimano Springs

Waiawa Springs.

Waikele Springs. 41

Wells $\ldots . . . .62$

Aquifer properties

Water-level fluctuations and changes in storage 44 
Basal ground water in southern Oahu-Continued Page

Transition zone. .

Evolution of the transition zone

Effects of pumping . .

Transition zone at the Pearl Harbor springs . ...

Behavior of the transition zone in response to changes in the position of the lens . . 62

Utilization of basal water

Quantity of water available....... 70

Methods of development . .

Artificial recharge of floodwater........ 72

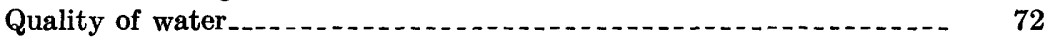

Sources of dissolved solids . . . . .

Expression of analyses . . . .

Quality in relation to use of water .

Geochemical cycle

Rainfall .

Sea water.......... 85

Effect of terrestrial environment on rainwater.

Composition of uncontaminated water.

Expression of composition .

Stream water.

Dike water . . . .

Basal water in the Koolau Volcanic Series........... 91

Perched water in the Honolulu Volcanic Series....... 92

Solution from the terrestrial environment._._._.

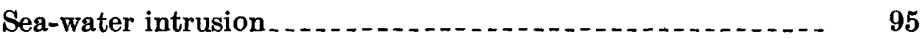

Composition of intruded water and its effect in the zone of mixture

Variation in content of elements of low concentration _._ $\quad 107$

Effect of irrigation water on the chemistry of basal ground water -

Contamination from fertilizers

Contamination from reaction in the soil profile........

Changes in basal water

Caprock water

Temperature of the water

Temperature of atmosphere and rainfall

Temperature of recharge water.....

Temperature of the basal aquifer . .

Temperature of intruded saline water.

Summary ... _..._.

References..... 128

Index . 131 


\section{ILLUSTRATIONS}

Plate 1. Map of southern Oahu showing streams, springs, wells, shafts, and tunnels . . . . . . In pocket

FigURE 1-2. Maps of Oahu showing:

1. Area of study and geomorphic provinces....... 4

2. Distribution of rainfall_._.

3-5. Graphs showing:

3. Distribution of rainfall along Kipapa Ridge_._._. 8

4. Logarithmic distribution of rainfall along Kipapa Ridge........ 9

5. Rainfall in central and southern Oahu ........ 10

6. Map of the Pearl Harbor area showing depth of the base of the caprock

7-10. Diagrams showing:

7. Pattern of movement through a fresh-water lens.

8. Effect of pumping on the transition zone........

9. Half the cross section of an idealized elongate island in three different hydraulic conditions........

10. The short-term effect of recharge on the shape of the fresh-water lens.

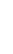
9 0

11. Map of southern Oahu showing ground-water areas, distribution of the caprock, and distribution of irrigated land.

12. Section of the caprock in the Waiau Springs area

13-16. Graphs showing:

13. Relationship of head at well 193 to flow from Pearl Harbor springs . . . . . . . . . . . . . . . . .

14. Head at well $193,1919-57$, and pumpage from Pearl Harbor area, 1901-57.

15. Head at well 193 and rainfall in the Koolau Range.

16. Change in chloride content of water with depth in test hole T-67.

17-19. Graphs showing draft at:

17. Oahu Sugar Co. pumps 6 and 6-B and the Navy Waiawa shaft, head at well 190 , and chloride content at pumps 6 and 6-B. . . . .

18. Ewa shaft, head at Ewa pump 1, and chloride content of water at Ewa pumps 1, 3, 4, 7, and

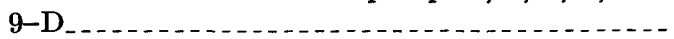

19. Honolulu Plantation Co. pumps 4-E and 4-H, the Navy Halawa shaft, the Board of Water Supply Halawa shaft, and the Honolulu Plantation Co. Aiea shaft............

20-21. Graphs showing:

20. Decrease in chloride content of water in well 7-F at the Honolulu Board of Water Supply Kaimuki pump.

21. Chloride content and head at well 153 for the years 1924-58. 
22. Map showing the approximate change in position of the 200- and 1,000-ppm isochlors between 1910 and 1950 .-

23. Diagram showing generalized pattern of discharge at springs in the Pearl Harbor area

24-26. Maps showing distribution of the chloride content of ground water in the:

24. Kalauao Springs area

25. Waimano Springs area

26. Waiawa Springs area

27. Graph showing the relation between chloride content of water at Waiawa Springs and head at well 201

28-29. Graphs showing the relation between chloride content of water and head at:

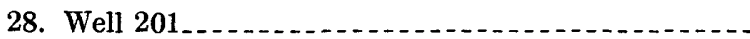

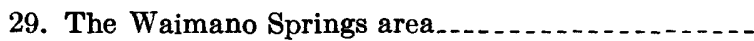

30-32. Diagrams showing:

30. Generalized flow lines in a Ghyben-Herzberg lens.--

31. The expansion of the Ghyben-Herzberg lens during high recharge.......

32. The contraction of the Ghyben-Herzberg lens during reduced recharge....................

33. Diagram classifying water on basis of sodium and salinity hazards . . . . .

34. Curves showing relation between hardness and chloride

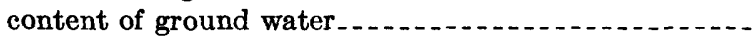

35. Diagram showing the relation between chloride content of rainwater and amount of rainfall

36. Diagram comparing the chemical compositions of sea water and ground water, stream water, and rainwater.-

37-40. Graphs comparing ion content, as indicated, in well water in area 2 with that in diluted sea water:

37. Calcium . . . 98

38. Magnesium

39. Total major cations _.

40. Sulfate _.

41-43. Graphs comparing ion content, as indicated, in well water in area 6 with that in diluted sea water:

41. Calcium ........ 102

42. Magnesium 103

43. Major cations. . . .

44. Graph showing concentrations of nitrate, sulfate, and silica in water from various sources in southern Oahu ... 


\section{TABLES}

Table 1. Flow of Pearl Harbor springs . .

Page

2. Comparison of quality of water from shaft 14 and well 88 with drinking water standards

3. Comparison of salinity and sodium hazard with cation content and specific conductance of ground water and sea water.

4. Average composition of rainfall at localities on Hawaii and Oahu

5. The composition of sea water

6. Representative chemical analyses of basaltic rocks and soils derived from basalt

7. Comparison of the mode, median, and mean of chemical constituents of water in dike compartments in the Koolau Range.

8. Chemical composition of uncontaminated natural water - -

9. Calculated quantities of chemical constituents dissolved from basalt of the Koolau Volcanic Series in water from various sources and relative mobility of the most abundant constituents

10. Comparison of major cation and sulfate concentrations of saline water intruded into the basaltic aquifer with those of sea water.

11. Comparison of dissolved constituents in water from test hole $\mathrm{T}-67$ with those in sea water. . .

12. Representative concentrations of silica, bicarbonate, sulfate, and nitrate in water from various sources . . ....

13. Comparison of $\mathrm{pH}$ and concentrations of carbon dioxide, bicarbonate, and chloride in caprock water, basalt aquifer water, and sea water.

14. Comparison of concentrations of constituents that vary with chloride content in water in the caprock and the basalt aquifer and in sea water.

15. Soil temperatures at various depths in the Kipapa Stream basin

16. Average ground-water temperatures in tunnels in the Koolau Range.

17. Temperatures of ground water from wells and shafts in the Honolulu area

18. Temperatures of water flowing from the Pearl Harbor springs

19. Temperature and chloride concentration of water at various depths below sea level in test hole $\mathbf{T}-67 \ldots \ldots$ 


\title{
GROUND-WATER RESOURGES IN SOUTHERN OAHU, HAWAII
}

\author{
By F. N. Visher and J. F. Mink
}

\begin{abstract}
\end{abstract}
Southern Oahu is underlain by an extensive basal aquifer that contains large supplies of fresh water floating in the sea water that saturates the rocks below sea level. Since the late 1800 's development and use of the water have supported the growth of large urban, industrial, and military activities and the widespread planting and irrigation of sugarcane in southern Oahu.

The water-bearing rock consists mostly of thin-bedded lava flows having generally high permeability. Recharge to the ground water is from rainfall on the Koolau Range. A caprock consisting mostly of sedimentary deposits overlies much of the southern coast of the island. Because it is less permeable than the water-bearing lava flows, the caprock retards the seaward flow of ground water and causes the levels of fresh basal water to stand higher than if the caprock were absent. Owing to the small difference between the specific gravity of the fresh water and the sea water in which it floats, the fresh water forms a lens that displaces sea water a distance below sea level about 40 times the height of the fresh water above sea level.

Under steady-state conditions of constant recharge and discharge, the dynamics of a fresh-water lens produces a sharp interface between the fresh and salt water. Under natural conditions, however, the sharpness is destroyed by mixing accompanying the movement of the interface caused by fluctuations in recharge and discharge and by forces such as tides acting on the water. As a result of the mixing, the salt water grades upward into fresh water through a transition zone that under some conditions may extend to the surface of the lens. The water in the transition zone is in a sense a part of the fresh-water lens, and like the fresh water, the saline water in the zone moves toward points of discharge at the shore. Saline water discharging from the transition zone is replaced by sea water moving into the rock from the ocean.

Pumping from wells in a fresh-water lens intercepts water that formerly moved to the shore and causes a thinning of the lens. If the rate of withdrawal is constant, only the part of the transition zone seaward of the well will thicken, but if pumping is intermittent the resultant thickening and thinning of the lens will increase the rate of mixing and cause the transition zone to thicken throughout the area affected by the well.

The water-bearing lava flows in southern Oahu form a virtually continuous aquifer that is divided into compartments or areas by thick and relatively impermeable fill in ancient valleys cut deep below present sea level into the lava rock. The heights of the basal-water levels above sea level, or heads, vary from compartment to compartment; the heads are highest in central Honolulu and decrease progressively eastward and westward. In the late 1880's the highest basal heads in southern Oahu were about 42 feet in central Honolulu and 32-35 feet in the Pearl Harbor area. 
Pumpage from wells in the Pearl Harbor area increased from less than $20 \mathrm{mgd}$ (million gallons per day) in 1901 to $165 \mathrm{mgd}$ in 1912 . Since about 1919 the pumpage has averaged about $160 \mathrm{mgd}$. The lowering of head and shrinking of the lens resulting from this heavy withdrawal were accompanied by an inland movement and a thickening of the transition zone; eventually saline water moved into many wells drilled near the shore or to depths near or in the transition zone. Since the 1930's several shafts or basal tunnels having large pump capacity have been constructed for irrigation, municipal, and military use; however, the development of these large capacity sources has not resulted in a sustained overall increase in pumpage.

Since the beginning of development in the Pearl Harbor area, most of the water pumped from wells has been used to irrigate sugarcane fields. The water has been augmented by water pumped from large springs on the shore of Pearl Harbor and by water transported from windward Oahu in the Waiahole Ditch system, which was constructed in 1913. A large part of the water applied to irrigated fields moves to the basal-water table by deep seepage. During the long period of irrigation, the replenishment of the aquifer by return irrigation water has become important in the basal ground-water system.

Continued heavy draft for several decades in the Pearl Harbor area without large changes in the size and shape of the fresh-water lens is an indication that the pumpage during the long period has not exceeded the sustained yield of the system.

The additional water available in the Pearl Harbor area is the water flowing into the harbor from springs and wells along the shore of the harbor. The lowest flow of recent years from the springs and wells occurred in 1953 and 1954, when the base flow was about $44 \mathrm{mgd}$.

The additional water might be developed by pumping from wells inland from the springs and reducing the flow into the harbor by lowering the basal head. However, a lowering of the head now, as in the past, would decrease the thickness of the lens and tend to increase the salinity of the water at some wells. The most direct approach to development of the additional water would be to collect the flow before it enters the harbor and to pump it to places of use.

Additional water may be available for development in the Honolulu area. The amount can be determined best by gradually increasing the pumpage and observing the effects on the water levels and the salinity of the water.

The sources of dissolved constituents in the basal ground water are the sea, the atmosphere, the mantle and the rock through which the water moves, and the fertilizer salts applied to cultivated fields.

Rainfall on the island contains a minimum of about $14 \mathrm{ppm}$ (parts per million) of dissolved solids. As the water moves through the soil and rock, the concentration increases and when it reaches the basal-water table, the water contains as much as about $200 \mathrm{ppm}$ of dissolved solids.

Recharge entering the basal aquifer by deep seepage from irrigated and fertilized flelds may add substantially to the concentration of dissolved material in the basal water. Some irrigation water pumped from wells extending into the transition zone has concentrations of more than $1,000 \mathrm{ppm}$. Fertilizers applied to the fields and to irrigation water add to the dissolved solids. Increases in sulfate and nitrate content are especially marked in parts of the aquifer recharged from irrigated fields, where the concentrations sometimes amount to 8-9 times those in basal water uncontaminated by return irrigation water.

Sea water intruded into the basalt aquifer differs chemically from the water in the open ocean. The chloride content is not affected as the sea water moves 
from the ocean into the rock, but the content of calcium, magnesium, sodium, potassium, and sulfate changes appreciably. The change in the cations is attributed to ion exchange occurring as the sea water moves inland through sediments on the ocean bottom. The exchange results in an increase in the calcium and magnesium content of the water and a decrease in sodium and potassium. A decrease in sulfate content is attributed to the reducing action by organic matter and anaerobic bacteria on the sulfate in the sea water as it moves through the bottom sediments into the rock.

\section{INTRODUCTION}

\section{PURPOSE AND SCOPE}

The work discussed in this report was begun in July 1956, and was done in cooperation with the Hawaii Division of Hydrography, Department of Public Lands (now Division of Water and Land Development, Department of Land and Natural Resources), using funds contributed to the division by the Hawaii Economic Planning and Coordination Authority and by the City and County of Honolulu. Its purpose was to investigate the basal groundwater supply in southern Oahu, determine the geologic and hydrologic conditions that control the quality and availability of the water, and obtain information on the amount of additional water that can be developed in the area. The study is a part of a series of comprehensive investigations of the water resources of the island of Oahu made by the U.S. Geological Survey in its cooperative program in Hawaii.

The report describes the character and extent of the basal aquifer, the relation of fresh to salt water in the aquifer, and the effects of pumping on the quality of the basal supply through 1958. It gives estimates of the quantity of additional water that can be developed, describes methods of development, and discusses the chemical quality of the water.

\section{LOCATION AND EXTENT OF AREA}

Southern Oahu is defined in this report as the part of the island of Oahu lying southwest of the crest of the Koolau Range, east of the summit of the Waianae Range, and south of the summit of the Schofield plateau (fig. 1). The area contains about 220 square miles, including about 10 square miles of the water surface of Pearl Harbor, and encompasses more than one third of the island.

\section{PREVIOUS INVESTIGATIONS}

The earliest systematic study of the water resources of Oahu was started by the U.S. Geological Survey in 1909, when it established a stream-gaging program in cooperation with the Territory of Hawaii. A study of high-level ground water in the Honolulu area was made 


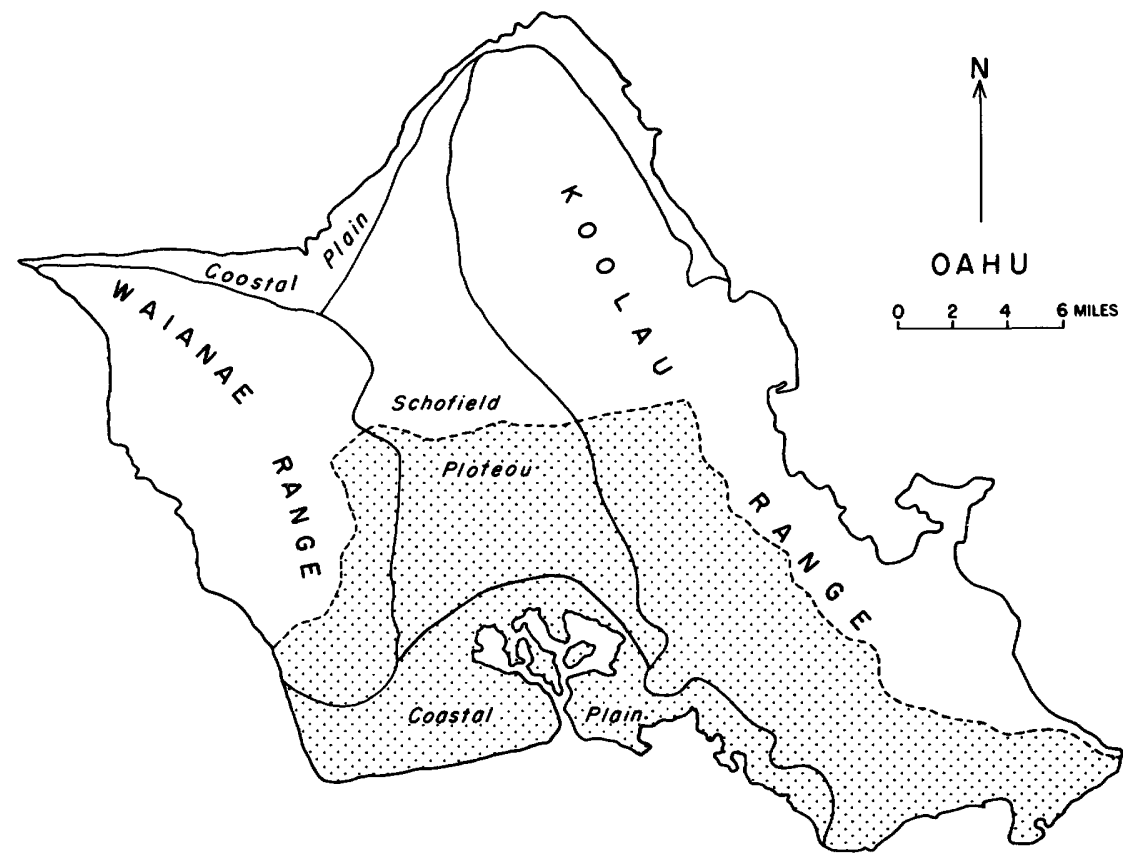

Frgurn 1.-Map of Oahu showing area of study and geomorphic provinces.

by H. S. Palmer in 1921, which he followed with a study and a report (Palmer, 1927) on the artesian water system in the Honolulu area. In 1930, H. T. Stearns and K. N. Vaksvik, of the U.S. Geological Survey, undertook the systematic geologic mapping of Oahu and the compilation and interpretation of hydrologic data in cooperation with the Territory of Hawaii. This work resulted in reports discussing the whole island (Stearns and Vaksvik, 1935, 1938; Stearns, 1939). A few years later a supplement to the reports was prepared by $H$. T. Stearns and G. A. Macdonald (1940). The Honolulu Board of Water Supply, recognizing the necessity of a dependable water supply for the growing city of Honolulu, sponsored intensive investigations in the Honolulu area by C. K. Wentworth starting in 1934 (Wentworth, 1951).

Preliminary findings in the present investigation were presented in a report by Visher and Mink (1960), which concluded that as of 1958 salt-water encroachment was not active in the area and that about $50 \mathrm{mgd}$ (million gallons per day) could be developed. These conclusions are unchanged in the present report.

\section{PERSONNEL AND ACKNOWLEDGMENTS}

This investigation was assisted by J. G. Ferris, hydraulic engineer, who visited the project in the early part of the work, by H. E. Thomas, 
and G. F. Worts, Jr., geologists, who reviewed various phases of the study on several occasions, and by H. H. Cooper, Jr., hydraulic engineer, who gave valuable advice in studies of salt-water encroachment during several visits to the project. Chemical analyses of several samples of water were made under the supervision of J. H. Feth. Streamflow records were collected under the supervision of $\mathrm{H}$. S. Leak, district engineer of the Surface Water Branch. Rose M. Maruoka, physical science aid, assisted in compilation of records and in many of the computations. Sam Wong, hydraulic engineer, of the Hawaii Division of Hydrography, assisted in the fieldwork and in the collection of records.

Parts of the report dealing with quantitative aspects of the basal ground water are the work of Mr. Visher. Sections on the geology and the chemistry and temperature of the water were prepared by Mr. Mink.

The writers are indebted to the Board of Water Supply of the City and County of Honolulu, the Suburban Water System of the City and County of Honolulu, the Public Works Office of the Fourteenth Naval District, the Hawaiian Electric Co., the Oahu Sugar Co., and the Ewa Plantation Co. for the wholehearted cooperation and assist. ance they provided during the investigation.

\section{GEOGRAPHY}

\section{SURFACE FEATURES AND DRAINAGE}

The part of Oahu discussed in the study may be divided into four geomorphic provinces (fig. 1) : (1) the Koolau Range, (2) the Waianae Range, (3) the Schofield plateau, and (4) the coastal plain.

The Waianae and Koolau Ranges are two large shield volcanoes. The Waianae Range was built by lavas from the Waianae volcano, the older of the two. Later, the outpouring of lavas from the Koolau volcano built the Koolau Range and the Schofield plateau. The coastal plain, which was built after the cessation of major volcanic activity, is underlain by terrestrial and marine sedimentary deposits and by lava flows and pyroclastic deposits of late volcanic activity.

About 25 streams, which have drainage areas ranging from less than 1 square mile to about 45 square miles, drain southern Oahu (pl. 1). Their courses follow the original consequent radial drainage pattern that formed on the flow slopes of the Koolau and Waianae volcanic domes. In the Honolulu area, the streams are 3-6 miles long, and most flow in flat-bottomed alluviated valleys bounded by steep walls 1,000-1,500 feet high. Streams flowing into Pearl Harbor are longer and less direct. The longest is Waikakalaua Stream-Waikele Stream, which follows an arcuate path for about 14 miles from its head in the 
Koolau Range across the Schofield plateau to Pearl Harbor. Only two streams, both intermittent, flow into Pearl Harbor from the Waianae Range.

In the Honolulu area the Palolo, Manoa, Pauoa, Nuuanu, and Kalihi Streams are fed by high-level springs flowing from dike compartments and perched aquifers and are perennial. The streams flowing into Pearl Harbor receive little or no water from high-level aquifers, but the larger ones are perennial in their upper reaches because of runoff from persistent rainfall on the highlands throughout the year. Several streams are perennial in reaches at altitudes below about 20 feet as a result of spring discharge from the artesian part of the basal ground-water body. In the intermediate parts of these streams, most of the runoff from rainfall, except flood flow, is lost by infiltration through the stream bed.

\section{CLIMATE}

Oahu, which lies a little south of the Tropic of Cancer and within the belt of northeast trade winds, has a mild and equitable climate throughout the year. The mean annual temperature near sea level in the city of Honolulu is $75.2^{\circ} \mathrm{F}$. The lowest temperature ever recorded there is $57^{\circ} \mathrm{F}$ and the highest, $90^{\circ} \mathrm{F}$. The average daily range in Honolulu is $9.1^{\circ} \mathrm{F}$. January and February, the coldest months, average $72.0^{\circ} \mathrm{F}$, and August, the warmest, averages $78.5^{\circ} \mathrm{F}$. The decrease in temperature with altitude is about $3^{\circ} \mathrm{F}$ per thousand feet.

The mean maximum relative humidity in Honolulu is 76 percent and the mean minimum is 59 percent. The maximum occurs just before sunrise; the minimum, shortly after noon. The mean wind speed is $11.6 \mathrm{mph}$, and the prevailing wind direction is east-northeast, the direction of the trade winds.

\section{AIRMASS CIRCULATtoN}

In general, two patterns of airmass circulation affect the weather of the Hawaiian Islands. The dominant is the anticyclonic pattern that produces the trade winds. Less frequent is a cyclonic pattern, which often results in southerly winds and the sultry, humid conditions commonly called kona weather. The anticyclonic pattern is caused by a fairly stable high-pressure region north of the islands. The pattern becomes cyclonic when the stable high-pressure cell breaks down and is replaced temporarily by intruding low-pressure airmasses, which are generally accompanied by frontal activity. Sometimes elements of both cyclonic and anticyclonic flow are mixed. According to Yeh and others (1951, p. 36), the anticyclonic pattern is dominant 66.6 percent of the time; the cyclonic pattern, 22.3 percent; and mixed situations, 11.1 percent. The anticyclonic, or trade- 
wind, pattern occurs throughout the year, but it is about half as frequent in winter as it is in summer. The cyclonic pattern may occur at any time of the year, but it is much more common during the winter.

\section{RAINFALR}

The areal variation in annual rainfall on Oahu is very great. As little as 20 inches falls on the extreme leeward coast, and as much as 300 inches falls in the central Koolau Range(fig. 2). These differences in rainfall are remarkable because they occur within a distance of only about 15 miles. In general rainfall decreases progressively from the mountains toward the sea.

Rainfall on the island may result from either anticyclonic or cyclonic flow patterns. Anticyclonic circulation causes orographic rainfall as the warm moist air of the trade winds is cooled rapidly as it rises along the steep windward slopes of the mountains. The trade winds blow from the northeast, approximately perpendicular to the trend of the Koolau Range. Where the mountains are less than about 5,000 feet above sea level, as is true of the Koolau Range, the airmass passes over the summit, and the rainfall reaches a maximum on the leeward side of the crest. In the central part of the Koolau Range, this maximum is about half a mile southwest of the crest. Farther to the south-

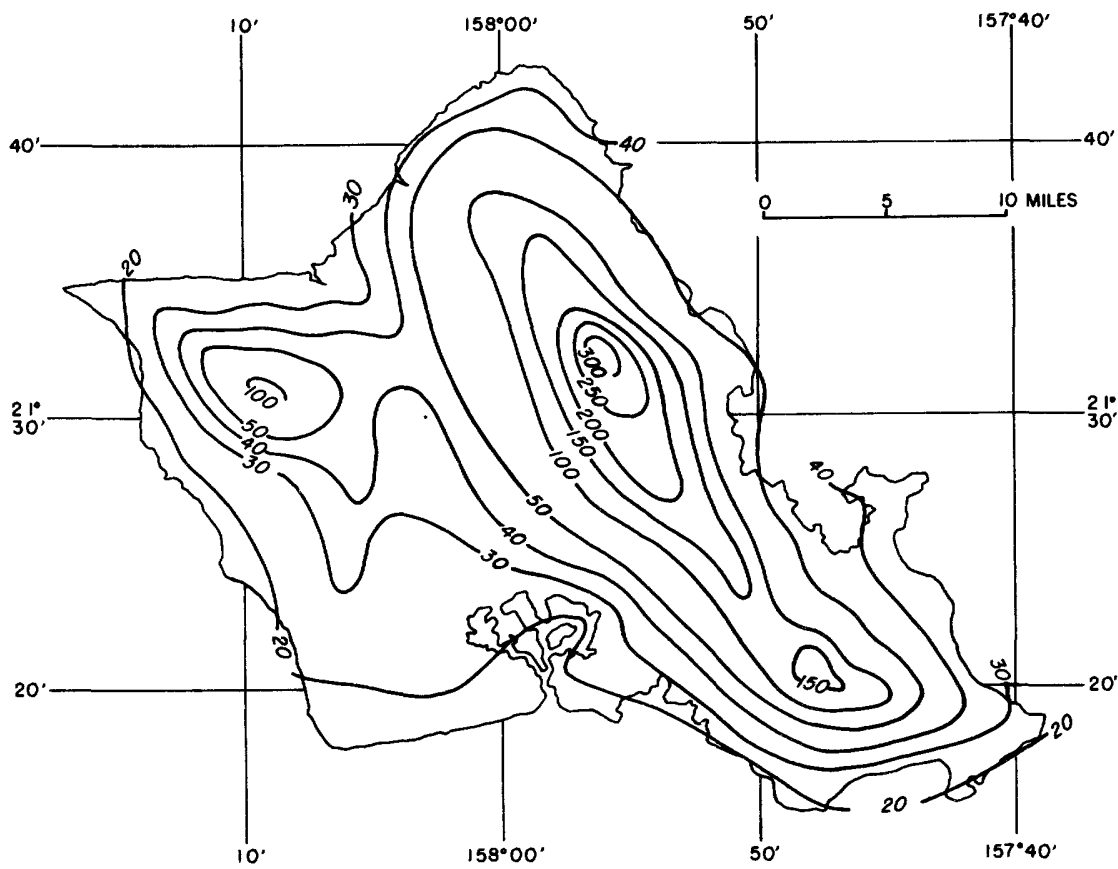

Figdre 2.-Map of Oahu showing distribution of rainfall. Isohyetal lines, showing precipitation in inches, by U.S. Weather Bureau. 


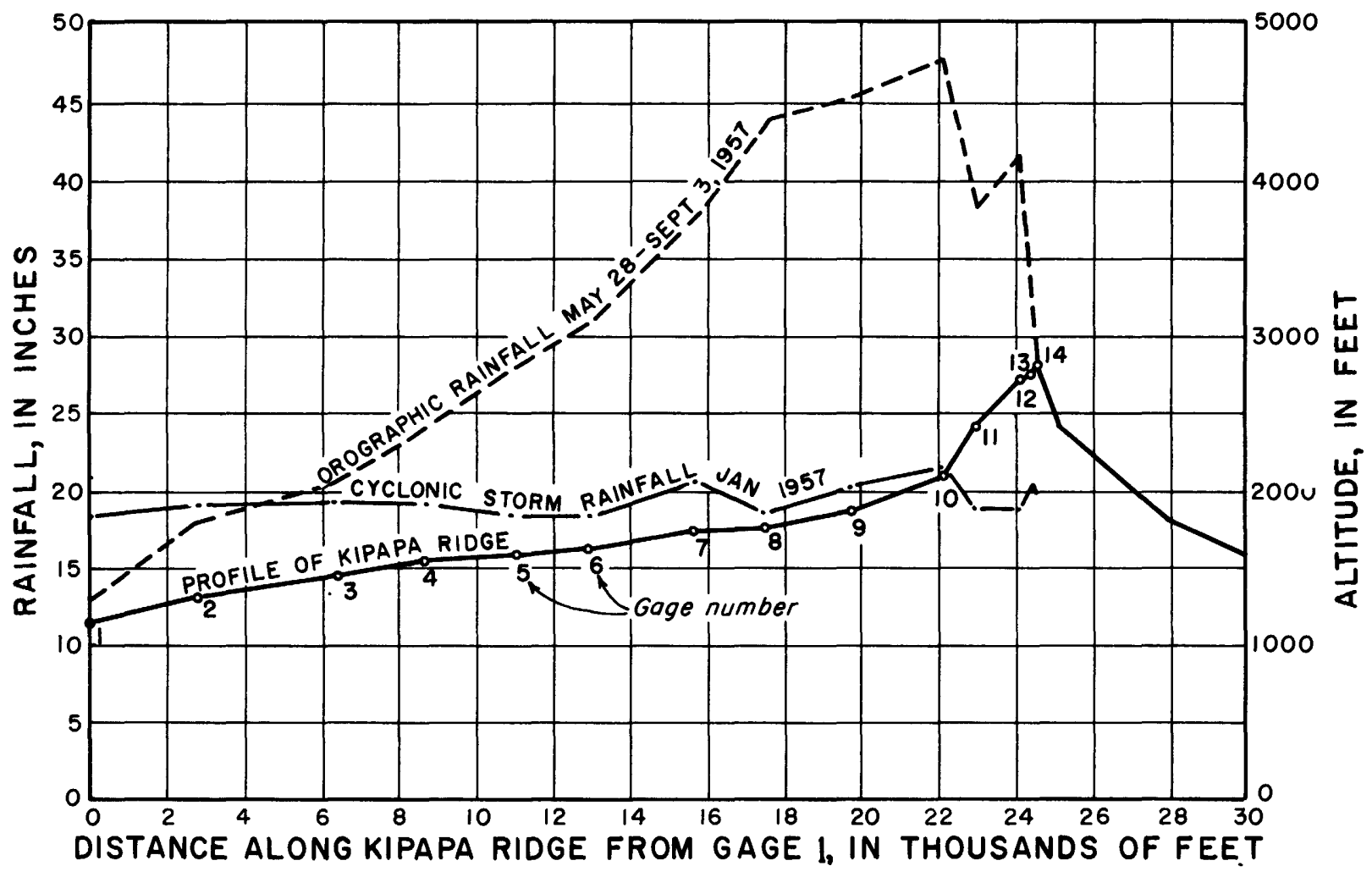

Figurm 3.-Graphs showing profle of Kipapa Ridge and comparing distribution of orographic and cyclonic rainfall along the ridge. 
west the rainfall decreases according to a geometric regression with the distance (Mink, 1960).

The pattern of distribution of orographic rainfall in the central Koolau Range is illustrated and compared with cyclonic rainfall distribution in figure 3. The rainfall records were collected monthly during 1957 from a series of 14 gages distributed over a distance of 24,500 feet along the ridge on the south side of Kipapa Gulch and on a line about normal to the trend of the crest of the range. Gage 1 is at an altitude of 1,100 feet, and gage 14 is at an altitude of 2,785 feet. The geometric spacing of the orographic isohyets, based on the same data, is illustrated by the logarithm of the ratio of rainfall at each gage to that at gage 8 (fig. 4). The amount of orographic rainfall on the leeward coastal area is small in comparison with the quantity falling on the high part of the Koolau Range. The trade-wind air has been robbed of much of its moisture by the Koolau Range before it reaches the slopes of the Waianae Range. Rainfall in the Waianae Range is therefore considerably less than that in the Koolau Range.

Cyclonic circulation, in contrast to trade-wind flow, provides a rather uniform rainfall distribution in the central Koolau Range (figs. 3 and 4) and throughout the island. Most of the rainfall in the drier regions comes from cyclonic storms, and the greater part of mountain rainfall comes from the trade winds. Because the cyclonic flow pattern is most common during the winter, the dry leeward areas have

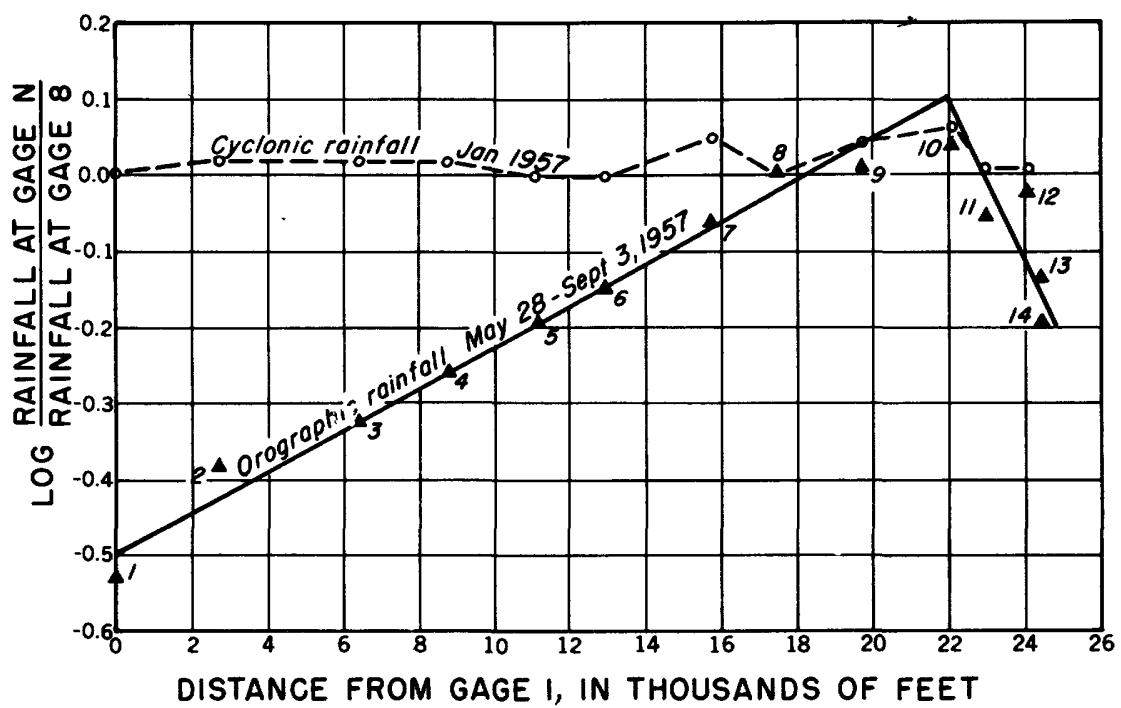

FIGURE 4.-Graph illustrating logarithmic distribution of orographic rainfall and uniform distribution of cyclonic rainfall along Kipapa Ridge.

$709-9700-64-2$ 


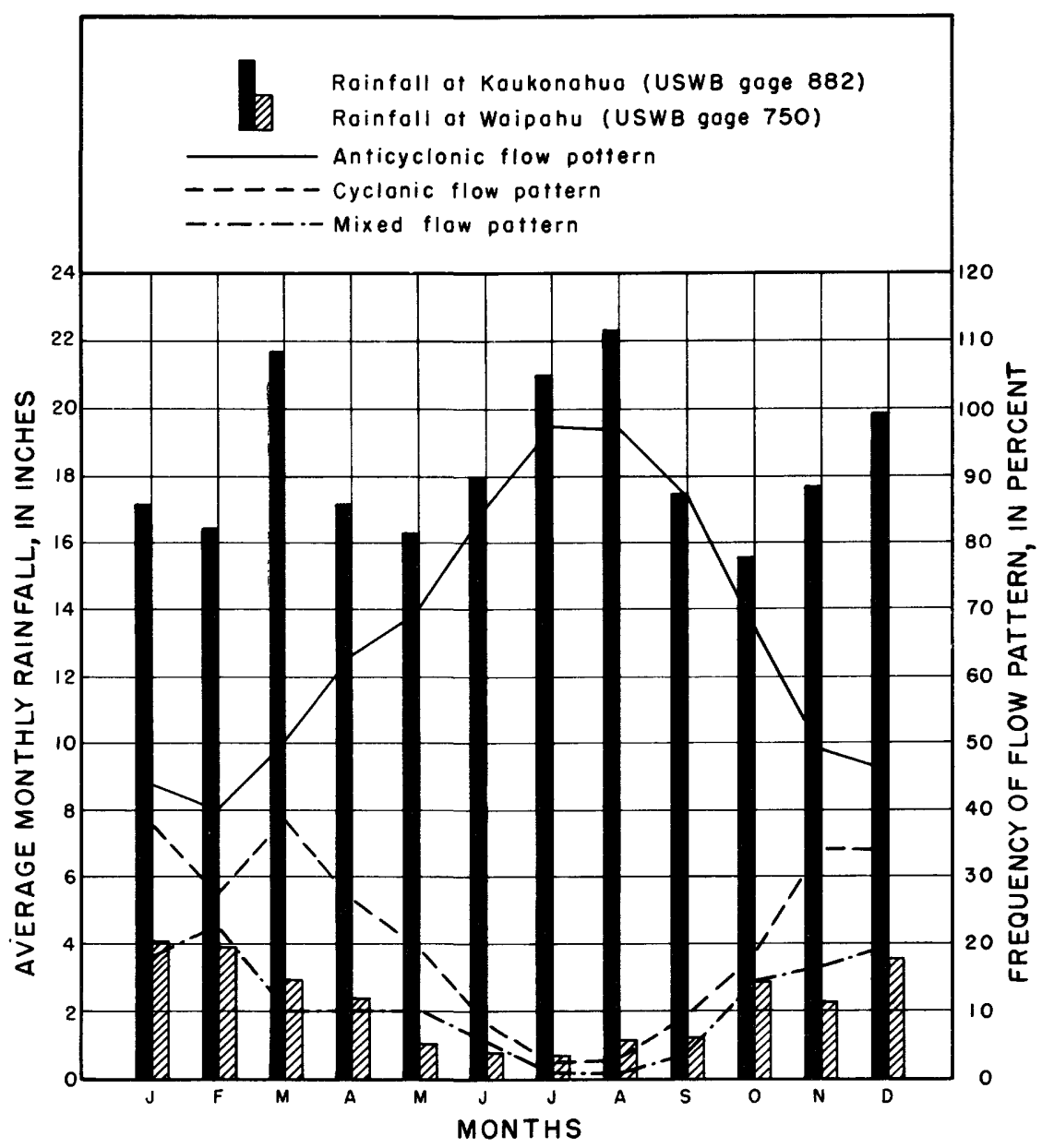

Figure 5.-Graphs showing rainfall in central and southern Oahu and the frequency of occurrence of anticyclonic, cyclonic, and mixed air-flow patterns.

relatively wet winters and dry summers. In contrast, the Koolau Range and the higher parts of the Waianae Range receive heavy rainfall the year around. This difference is shown in figure 5 by means of graphs of the average monthly rainfall at a station in central Oahu near the coast and at a station in the central Koolau Range, 10 miles away.

The coastal station (USWB 750) at Waipahu is 60 feet above sea level and less than half a mile from the shore of Pearl Harbor. The mountain station (USWB 882) on Kaukonahua Stream is 1,200 feet above sea level and 2 miles southwest of the crest of the Koolau Range. The Waipahu station has an average yearly rainfall of 27 inches; at 
Kaukonahua the yearly average is 220 inches. The average monthly frequencies of anticyclonic, cyclonic, and mixed flow patterns, as given by Yeh and others $(1951$, p. 36$)$ are also plotted on figure 5 . The graphs show that most of the rainfall near the leeward coast occurs in the early and late parts of the year and that rainfall in the central Koolau Range is more uniformly distributed through the year; in 2 of the 3 highest months, July and August, rainfall occurs during the time of greatest anticyclonic activity.

\section{DEVELOPMENT}

Oahu is the center of commerce, shipping, industry, and government in Hawaii. Most of these activities are concentrated in southern Oahu, which is the site also of large military installations, sugarcane and pineapple plantations, and extensive facilities for tourists. Most commercial and service activities are in Honolulu. Industrial development occurs adjacent to Honolulu Harbor and on lowlands west of Pearl Harbor. Military installations are found in the Pearl Harbor area and on the Schofield plateau. Sugarcane and pineapple plantations lie on gentle slopes and lowlands around Pearl Harbor. The tourist industry is concentrated at Waikiki in Honolulu.

In 1960 , the population of southern Oahu was nearly 400,000 , or almost four-fifths of the population of the whole island and roughly two thirds of the total population of Hawaii.

Most of the water used in southern Oahu is for the irrigation of sugarcane fields. The irrigation supplies come largely from wells operated by the plantations; some irrigation water is imported from the northeast, or windward, side of the island. Municipal and industrial supplies also are pumped mostly from wells; much of the water is provided by the Honolulu Board of Water Supply. Wells are the source of water used at military installations.

\section{GEOLOGY}

The discussion of the geologic history and the description of the rocks of southern Oahu are based largely on the work of Stearns and Vaksvik (1935), Stearns and Macdonald (1940), Wentworth (1926, 1951), Palmer (1927), and Wentworth and Winchell (1947). In the present study geologic field studies were limited to the examination of small areas of special interest.

\section{GEOLOGIC HISTORY}

The Hawaiian archipelago consists of the emerged peaks of an immense volcanic ridge trending northwestward in the central Pacific Ocean over a distance of about 1,600 miles from the island of Hawaii to Kure Island. The large and habitable islands, from Niihau to 
Hawaii, extend over a distance of 380 miles on the southeastern end of the ridge. The northern part of the ridge began to form probably in early Tertiary time and the southern part somewhat later in the Tertiary along a fracture in the earth's crust that was caused possibly by tensional stresses above a zone of divergence between two thermal convective cells in the viscous subcrust (Dietz and Menard, 1953, p. 110). Basaltic magma erupted from this fracture and built the ridge in the form of shield volcanoes, many of which grew to considerable heights above sea level. The extrusion of such immense quantities of lava eventually caused isostatic adjustment and downbowing of the crust in the vicinity of the ridge. The presence of a depressed area along the base of the ridge and of a great gentle arch northwest of this trough is evidence of isostatic regional compensation (Dietz and Menard, 1953, p. 110; Hamilton, 1957, p. 1022-1026).

\section{SHIELD VOLCANOFS}

The shield volcanoes that formed the ridge were broad gently sloping ellipsoidal domes, each of which covered an extensive area. They were built generally of thin basaltic lava flows. The original surfaces of the domes had slopes of 3-10 degrees.

The remnants of two of the shield volcanoes form the island of Oahu. The western part of the island is the eroded Waianae volcano, which was the first to emerge above sea level; the eastern part consists of the eroded dome of the Koolau volcano. Both volcanoes grew rapidly, but the Waianae dome, because of its earlier emergence, was deeply eroded before the Koolau dome reached its maximum height. Probably neither dome reached a height greater than 5,000 feet above the present sea level.

The Koolau dome trends northwestward for about 35 miles; the Waianae dome trends northward over a distance of about 20 miles and has a marked convexity towards the east. The building of the Waianae dome was not continuous, as is shown by an erosional angular uneonformity between its earlier and later flows. No erosional breaks appear in the building of the Koolau dome, but Palmer (1955) pointed out evidence of unconformities in lavas on the southwestern slope of the dome. Piling up of lavas from the Koolau dome against the eroded lower slopes of the Waianae dome produced the broad gently sloping feature called the Schofield plateau. Eruptive centers postulated by Palmer (1955) may also have contributed to the height and shape of the Schofield plateau.

\section{SEDIMENTATION}

A long period of quiescence, marked by deep erosion of the domes and deposition of sediments in the lowlands, followed the outpouring 
of lavas that built the Waianae and Koolau domes. The deposition of sediments around the southern edges of the domes helped to build a flat coastal plain. Changes in sea level, caused by isostatic adjustment and the building and melting of the great glaciers in colder regions during Pleistocene time, greatly influenced the construction of this coastal plain. Great valleys were carved during low stands of the sea and then were filled with sediments as the sea level rose. The changes in sea level, which ranged from about 1,000 feet above to at least 1,200 feet below present sea level, were often accompanied by the growth of coral reefs and marine sedimentation. Today the fossil coral reefs and marine and terrestrial alluvial sediments constitute the bulk of the coastal-plain deposits. The sediments form a relatively impermeable caprock over the highly permeable lavas of the original domes.

\section{CHARACTER OF THE WATER-BEARING ROCKS}

Lava flows make up the bulk of Oahu, and they form the most important aquifers. Pyroclastic rocks occur in the southeast end of the Koolau Range and on the most southerly slope of the Waianae Range, but they are not important aquifers. Sediments underlying the coastal plain and the lower parts of valleys have comparatively small areas, but they are of great hydrologic significance because of the control they exert over the movement of ground water.

\section{LAVAS}

The lavas in southern Oahu issued mostly from the Waianae and Koolau volcanoes, and only a comparatively small quantity erupted from the vents of the Honolulu Volcanic Series. The lavas from the Koolau volcano have the greatest areal extent, and they are the largest and most important aquifers. Lavas from the Waianae volcano also are important aquifers, but the lavas of the Honolulu Volcanic Series are so limited in extent and volume that they contain only relatively small amounts of water.

In the Koolau dome and in the lower member of the Waianae dome, the layers, or flows, are generally not more than 10 feet thick. The flows of the middle and upper members of the Waianae dome are somewhat thicker but are not greatly different from the lower flows in their water-bearing properties. Depending on their physical state and the environment in which they cooled, the flows solidified into either pahoehoe or aa lava. Pahoehoe flows commonly grade into aa flows.

The permeability of unweathered flow rock that makes up the aquifers of Oahu is generally high. The principal flow structures con- 
tributing to the high permeability are clinker layers associated with aa, lava tubes in pahoehoe, irregular openings within and between the surface of flows, and contraction joints that formed on solidification of the lavas. Vesicles, which make up a large part of the total volume of rock, contribute greatly to the porosity, but they seldom are interconnected and have little effect on the permeability. Clinker beds, lava tubes, and interflow openings generally lie roughly parallel to flow surfaces, which normally have dips less than 10 degrees. Contraction joints have a generally vertical orientation. Therefore, the horizontal component of permeability of lava flows probably exceeds the vertical. However, permeability in both directions is so great and so subject to local deviations that any difference between them would be difficult to assess.

Weathering of the basaltic rock causes a decrease in the sizes of the openings in the lava flows and a reduction in permeability to less than that of the fresh rock. The loss in permeability commonly extends to depths of 50-75 feet below the surface. The effects of weathering reach greater depths adjacent to and under valleys.

\section{DIKES}

In and near the rift zones of the Koolau and Waianae volcanoes, many dikes cut the layered flow rock. In places the dikes are so closely spaced that they almost completely displace the lava flows of the country rock. In others they are widely spaced and form compartments enclosing large masses of permeable lava. The dikes are generally nearly vertical, and they are dense and have very low permeability. Because of their low permeability, the dikes impound ground water in many of the compartments that they enclose in the central parts of the Koolau and Waianae Ranges and possibly under the Schofield plateau in central Oahu.

\section{PYROCLASTIC ROCKS}

Pyroclastic materials on Oahu consist of cinder, ash, and tuff. Cinder consists of glassy vesicular fragments that are coarser than sand and as much as an inch in diameter. (Wentworth and Macdonald, 1953, p. 74.) Volcanic ash is generally composed of detritus ranging from dust to particles as much as $4 \mathrm{~mm}$. in diameter. The detritus consists of vesicular glass that in many places contains crystals of olivine, magnetite, and lesser amounts of related minerals. The term "tuff" in Hawaii ordinarily applies to the consolidated mottled brown and lavender palagonitized beds of pyroclastic debris found in southeastern Oahu (Wentworth and Macdonald, 1953, p. 57). The tuff occurs as indurated layers of palagonitized fragments of variable grain size. 
Unconsolidated and unweathered cinder is the most pervious of the pyroclastic materials. Its permeability is so great that it absorbs most of the rain falling on it. Cinder deposits in Oahu are too small to act as aquifers, but where they occur, such as in the Tantalus area of Honolulu, an unusually large proportion of the rainfall infiltrates through them. Volcanic ash is variable in permeability. Where it is weathered its permeability is very low, but where fresh it may be highly permeable. Weathered lenses of ash as much as about 8 inches in thickness occur sporadically within the masses of lava of the Koolau and Waianae domes, but they have no appreciable hydrologic effect because of their small extent. The tuffs of southeastern Oahu are among the most impervious rocks on the island. They never act as aquifers, but over small areas they are perching members. Where tuffs occur in the coastal-plain deposits, they make up a part of the upper section of the caprock.

\section{SEDIMENTARY DEPOSITS}

The coastal plain that borders southern Oahu is underlain largely by terrestrial and marine sedimentary deposits, which form a wedge that retards the seaward movement of fresh ground water from the basaltic aquifer. This wedge is locally called the caprock. The deposits in the caprock have differing degrees of permeability, but the overall effect is one of relatively low permeability in contrast to the fresh basaltic aquifer. The depth to the base of the caprock is shown in figure 6.

In its most comprehensive definition, the caprock includes terrestrial alluvium, marine sediments, calcareous reef deposits, pyroclastic rocks of the Honolulu Volcanic Series, and weathered basalt. The alluvium, marine sediments, and reef deposits make up the greatest volume of the wedge. The weathered basalt forms a continuous thin layer at the base, and the pyroclastics form thin discontinuous layers near the top. Near the inner shore of Pearl Harbor, the caprock consists only of alluvial sediments overlying weathered basalt. Reef deposits and other marine sediments interfingered with alluvium make up the part of the wedge under the ocean shore. Around Pearl Harbor, pyroclastic deposits are restricted to the southern and eastern sectors of the harbor area. The caprock in Honolulu is similar to that around Pearl Harbor, but in Honolulu pyroclastic rocks are more widespread in the upper part of the section.

'The term "caprock" is used in southern Oahu to include a section of sedimentary deposits and volcanic rock that act as a barrier to the seaward flow of ground water from the permeable basaltic aquifer. The permeability of components of the caprock vary widely from that of the almost impervious compacted old alluvium to that of the com- 


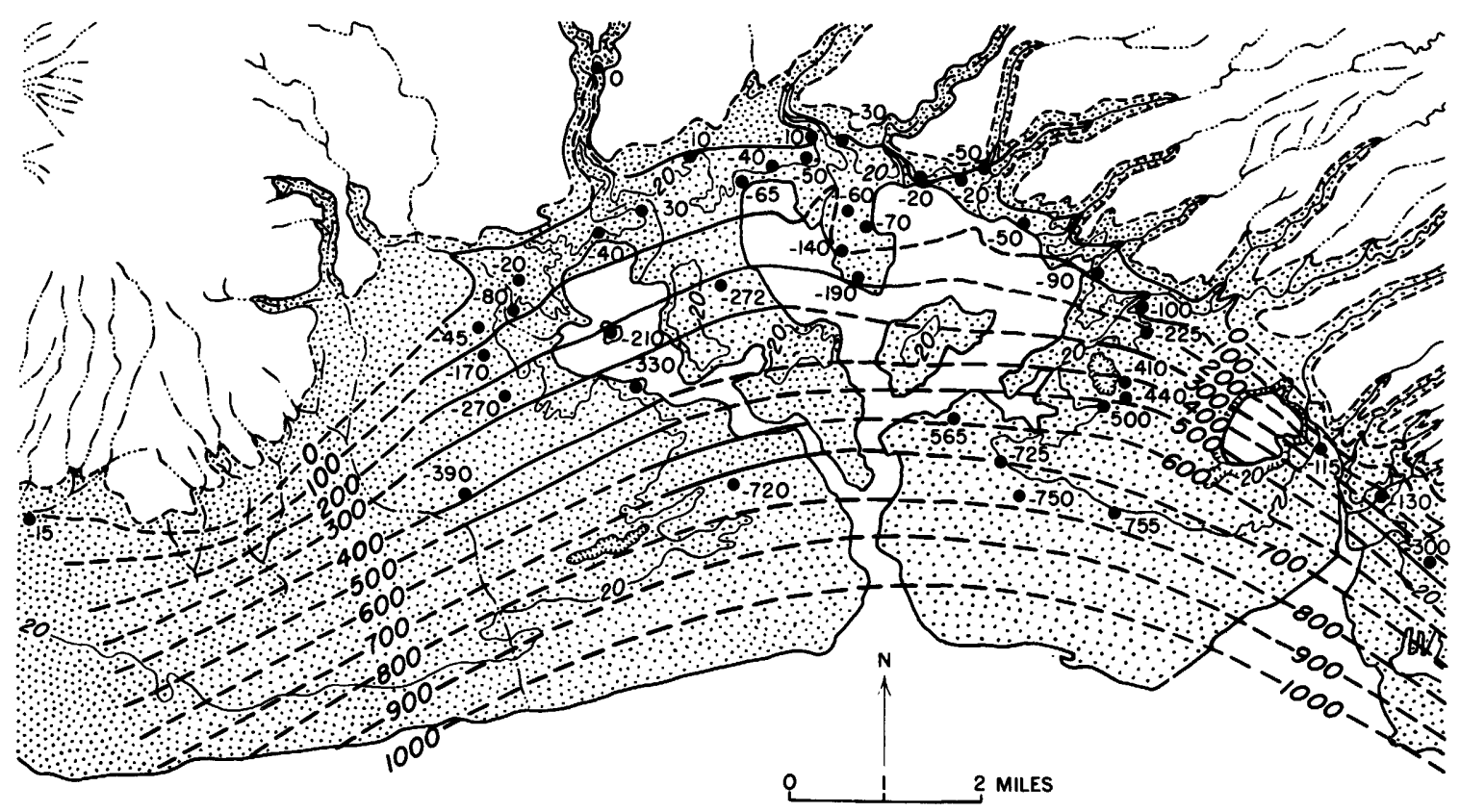

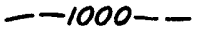

Structure contour

Drawn on the base of the caprock. Doshed where approximate Contaur interval 100 feet; dafum is mean sea level
$-750$

Well and depth of base of caprock, in feet below seo level

Figure 6.-Map of the Pearl Harbor area. Contour lines show the depth of the base of the caprock below sea level as indicated by well logs. 
monly cavernous reef rock. The overall effect, however, is one of low permeability.

The caprock contains large quantites of water, ranging in salinity from fresh to sea water. Near Ewa, sufficient fresh water for irrigation occurs in cavernous reef rock. The fresh water in the caprock comes from several sources, including rainfall on the caprock, return flow from irrigated fields lying on the caprock, springs flowing from the basaltic aquifer at the edge of the coastal plain, and water leaking into the caprock from the underlying artesian part of the basaltic aquifer. Compared to that of the basalt aquifer, however, the capacity of the caprock to store and transmit water is small. Except in the Ewa region, where return irrigation flow provides the large quantities of recharge, the caprock probably does not contain large developable supplies of fresh water.

\section{SOILS}

The upper slopes of the Koolau and Waianae Ranges are underlain by lithosols that have a loose porous structure and a high capacity to absorb water. On the lower slopes and in parts of the lowland of southern Oahu, the soils are mainly latosols having a friable open structure that allows quick downward percolation of water. The lithosols and latosols have developed mostly on lava flows and on upland deposits of terrestrial alluvium. On most of the alluvium in the lowlands, the soils are gray hydromorphic soils and dark magnesium clays. The soils are close textured and plastic and have low permeability.

The areas of large ground-water recharge-the rainy mountains and the upland irrigated sugar fields-are underlain largely by lithosols and latosols. The ability of these soils to absorb and transmit water readily permits a large part of the rainfall and irrigation water to move down to the water table.

\section{GROUND WATER}

Rainfall is the source of all fresh water in Oahu. A part of the rainfall runs off directly to the sea in streams, a part escapes into the atmosphere by evaporation and transpiration, and a part moves downward through the soil and rocks to the zone of saturation and becomes ground water. The ground water moves slowly through the rocks and eventually reaches points of discharge at springs and seeps in stream valleys and along the shore. 


\section{MODES OF OCCURRENCE}

\section{FIGH-LEVEL GROUND WATER}

A large part of the ground-water recharge in Oahu occurs in the mountains, which are an area of high rainfall. Much of this recharge is in areas where the lava flows are cut by many dikes, and the ground water in these areas, termed "high-level ground water," is impounded above sea level and separated from sea water by the relatively impermeable dikes (Stearns and Vaksvik, 1935, p. 370). Compartments formed by the dikes are commonly saturated to levels hundreds of feet above sea level, and the natural discharge from the compartments is largely at springs feeding mountain streams. The greatest discharge of high-level water is in windward Oahu on the northeast side of the Koolau Range, where valleys are cut deep into the dike complex. Fewer high-level springs flow from dike compartments in leeward valleys, of which only those in the Honolulu area are cut deep into the Koolau dome.

A shaft dug in 1936 near Wahiawa on the Schofield plateau penetrated high-level water standing about 275 feet above sea level in lavas of the Koolau Volcanic Series (Stearns and Macdonald, 1940, p. 20). The water underlies an area of several square miles (Swartz, 1940) and is impounded by dikes or other structural features, which are concealed by lava flows forming the Schofield plateau. The natural discharge from this high-level reservoir is underground and is concealed by the lava flows overlying the impounding structural features. Presumably a part of the discharge moves southward into the basal aquifer of the Pearl Harbor area.

Some high-level water is perched by beds of ash, soil, and alluvium intercalated in lava flows and pyroclastic deposits (Stearns and Vaksvik, 1935, p. 381-386). The beds are scarce in the lavas of the Koolau and Waianae Volcanic Series in southern Oahu, where perched water bodies in these lavas are small and supply only a few seeps and springs. Perching beds are more common in the scattered areas of lava and pyroclastic rock of the Honolulu Volcanic Series, and perched water flows at several springs from rock of this series in the Honolulu area.

High-level ground water is developed by means of many tunnels in Oahu. The greatest development is in the valleys of windward Oahu, where tunnels driven into dike compartments in the Koolau Range supply a large part of the municipal water used in the windward area. Large amounts are developed also in the Waiahole Ditch tunnel system, which diverts water from windward Oahu to sugarcane fields in the Pearl Harbor area. Most of the high-level development in southern Oahu is in the Honolulu area, where several tunnels supply water 
to the municipal system. Several wells pump water from the highlevel reservoir underlying the Schofield plateau.

\section{BASAL GROUND WATER}

The main water table in much of southern Oahu and a large part of the rest of the island stands near sea level. This is the basal water table, which ranges in altitude from a few feet to a few tens of feet, depending on the recharge, the permeability of the aquifer, and the presence of coastal deposits that are less permeable than the aquifer and that retard the seaward flow of the water. Because of recharge from rainfall, the upper part of the basal water body is commonly fresh; the fresh water forms a lens that floats in heavier sea water, which saturates the rock to unknown depths below sea level.

\section{THE FRESH-WATER LENS}

The fresher part of the basal ground water floating on sea water forms a lens-shaped body commonly called a Ghyben-Herzberg lens, or the Herzberg lens, after W. Badon Ghyben (1889) and Alexander Herzberg (1901), who described the occurrence of fresh water floating in and displacing sea water in permeable rocks in the coastal area of the Netherlands and in islands of the North Sea. This type of occurrence of fresh water in Hawaii was recognized many years ago by Andrews ${ }^{1}$ and by others (Palmer, 1957), but it was first appreciated fully in Hawaii by Palmer (1927) in his study of the geology of the Honolulu artesian system. Subsequent studies by Wentworth (1947, 1948, 1951), Stearns and Vaksvik (1935), Stearns and Macdonald (1942), and Cox (1954) have added much to the understanding of the occurrence of basal ground water in Hawaii and the hydrologic and geologic factors that promote and control a fresh-water lens in volcanic islands.

Under the assumptions of static conditions which were implicit in the early descriptions of the behavior of the Ghyben-Herzberg lens, the formula $Z=\frac{h_{f}}{\rho_{s}-\rho_{f}}$ defines the location of the bottom of the freshwater lens floating in sea water. In this equation, $Z$ is the distance to which the fresh water extends below sea level; $h_{f}$ is the height of the free fresh-water surface above sea level; $\rho_{s}$ is the specific gravity of sea water; and $\rho_{f}$ is the specific gravity of the fresh water. When the commonly used values of 1.025 for the specific gravity of sea water and 1 for the specific gravity of fresh water are placed in the equa-

\footnotetext{
${ }^{1}$ Andrews, C. B., 1909, The structure of the southeastern portion of the Island of Oahu : Unpublished manuscript thesis on file with Rose Polytechnic Institute, Terre Haute, Ind.
} 
tion, the value of $Z$ becomes $40 h_{f}$; that is, the depth of the base of the fresh water below sea level is 40 times the height of the water table above sea level. Actually, departures from the 40 to 1 ratio are common because of variations in temperatures and salinity that affect the densities of the fresh and sea water.

The expression for a static balance between fresh and sea waters takes into consideration the difference in the specific gravities of the two waters, which is a principal factor in the thickness and behavior of a fresh-water lens. The lens is, however, a dynamic system through which fresh water moves from an area of recharge to points or zones of discharge, and the energy involved in this movement affects the shape of the lens and the depth of the fresh water. Theoretical aspects of the depth and shape of a dynamic lens were discussed by Hubbert (1940) in his treatise on the motion of ground water. In the practical matter of water supplies in the fresh-water lens, the most important factors are the rate of recharge of fresh water, the permeability of the rocks that contain the water and control i.ts movement, and the effects of mixing of the fresh water with the sea water in which the lens floats.

Fresh water enters the lens by intermittent recharge from rainfall and moves through it to the sea where continuous, but fluctuating, discharge occurs at springs and seeps in a narrow zone at the shore (fig. 7). In an aquifer of a given uniform permeability, the thickness of the lens varies with the amount of water moving through it; that is, the thickness increases as the rate of recharge increases. Where a fixed rate of recharge occurs, the lens is thinner in an aquifer having high permeability than in one having low permeability.

The thickness of a lens may be affected also by relatively impermeable deposits that overlie the aquifer above and below sea level and separate it from the sea water. These deposits form a caprock on the aquifer that retards the escape of water from the lens and causes the thickness of fresh water to be greater than it would be if the deposits were absent. The magnitude of the effect can range from the minor local thickening caused by sandy beach deposits having permeabilities only a little less than the underlying lava flows to the formation of a very thick lens as the result of the presence of a caprock of extensive coastal deposits of impervious alluvium.

\section{TRANSITION BETWEEN FRESH AND SALT WATER}

Under steady-state conditions the dynamics of a fresh-water lens produce a rather sharp interface between the fresh and salt water (Hubbert, 1940). The sharpness of the interface, however, is destroyed when the interface moves with respect to the porous medium 


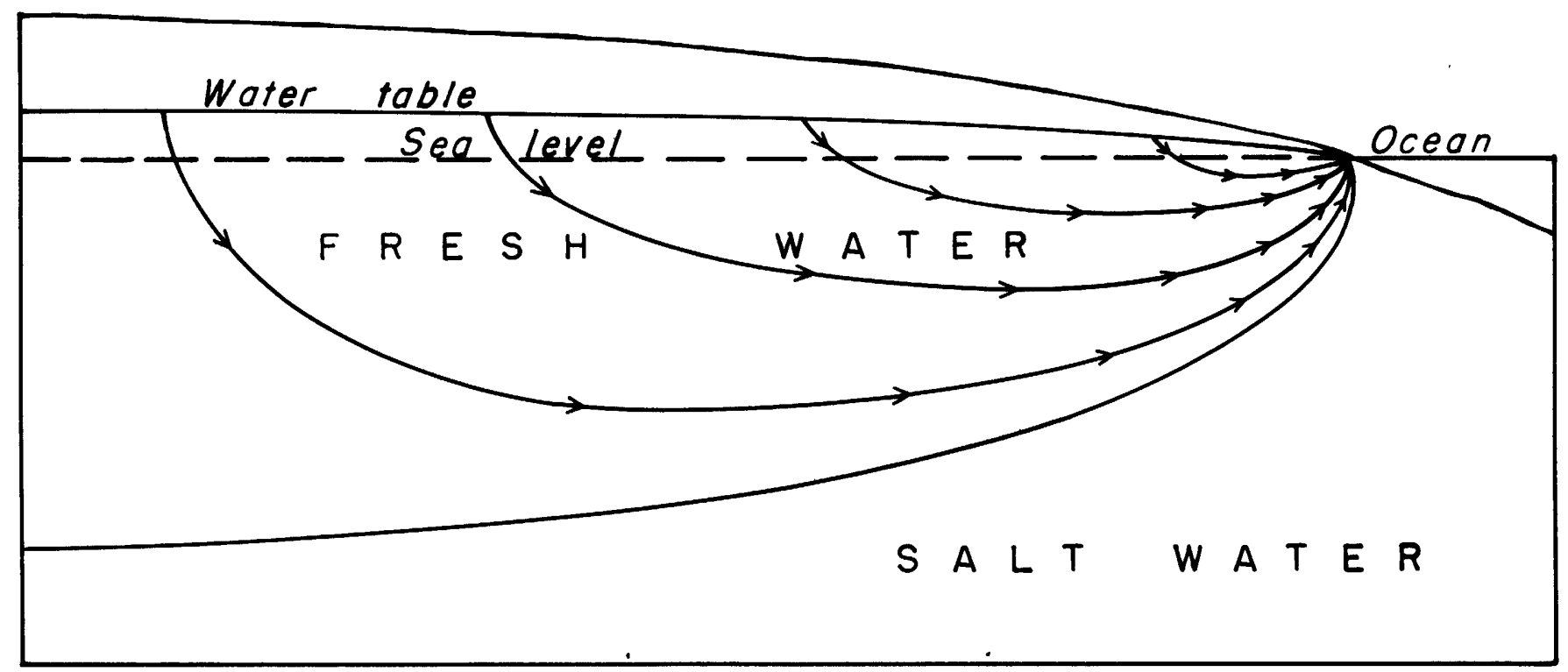

FIGURE 7.-Diagram showing the theoretical pattern of movement through a fresh-water lens fioating in sea water. The cross section shown is half of a hypothetical island receiving continuous rainfall distributed over the island. The height of the water table above sea level is greatly exaggerated. 
containing the fluids. The amount of mixing is proportional to the rate of movement of the interface. Under natural conditions the interface is constantly in motion because of the action of the tides and seasonal changes in the thickness of the lens caused by fluctuations in recharge. If the lens is small and the rock is highly permeable or if the tidal period is long, the entire lens rises and falls with the sea. Otherwise, the effect of the tide proceeds inland as a wave that diminishes in height as the distance from the coast becomes greater. Because of the tidal and seasonal movement, the path relative to the rock of a water particle passing through the lens is subject to many ups and downs.

As a result of mixing the salt water grades upward into fresh water through a transition zone that in some places extends to the surface of the lens. The water in the transition zone is in a sense a part of the fresh-water lens because it moves toward points of discharge at the shore; however, owing to its greater specific gravity the rate of movement is not as great as that of the fresh water. The thickness of the transition zone is determined by two factors: the rate at which mixing is taking place, and the rate at which the transition zone water is discharged at the shoreline. A change in either factor will result in a change in the thickness of the transition zone.

The most variable factor under natural conditions is likely to be the rate of movement of water in the transition zone toward the points of discharge. The rate is determined by seasonal and long-term variations in the rate of recharge to the fresh-water lens. A decrease in recharge reduces the amount of water moving through the lens and causes the direction of movement of water in the transition zone to change from lateral to vertically upward owing to shrinkage of the lens. This change then causes a reduction of the rate of discharge of water from the transition zone. An increase in recharge increases the amount of water moving through the lens and the rate at which transition zone water is discharged at the edge of the lens.

The mixing process causes salt water to be combined with fresh water; the mixture is subsequently discharged at the shore, and the salt water that is so combined and discharged is replaced by sea water moving in from the ocean. Under the gradient causing the sea water to move from the ocean floor to the transition zone, a lower head exists in the salt water under the island than in the open sea (Cooper, 1959).

Where sediments on the ocean bottom retard the flow of sea water into or out of the rock, the ebb and flow of water into and from the rock due to tidal action may be reduced, thereby reducing tidal mixing of salt and fresh water. Even where no exchange of water occurs, however, the alternate increase and decrease of the load on the seafloor sediments caused by the tides will prodnce some tidal fluctuation. 
Artificial discharge from the lens, such as heavy pumping from a well that amounts to a/considerable part of the total supply, causes marked changes in the system. The well intercepts water that formerly moved to the shore. The reduction in the amount of water moving to the shore in turn results in a reduction in gradient and thinning of the lens between the well and the shore. The lens also becomes thinner inland from the well but, as there is no change here in the amount of water passing through the lens, the gradient becomes steeper inland from the well to compensate for the loss in thickness. If the rate of withdrawal is constant, the transition zone can be expected to become thicker toward the coast, where velocities are reduced, and to become thinner inland, where velocities are increased. If pumping is intermittent, however, the resultant alternate thickening and thinning of the lens will increase the rate of mixing and cause the transition zone to thicken throughout the area influenced by the well. (See fig. 8.)

The interception of fresh water by a well reduces the amount of fresh wa,ter available in the part of the aquifer between the well and the shore and may cause increases in salinity of water pumped or flowing from other wells or springs in that area. If the mixing caused by intermittent pumping causes a decrease in salinity of the water below the bottom of the original transition zone, as well as an increase in salinity of water above, the result may be a thinning of the truly fresh part of the lens without a decrease in head.

The upper and lower surfaces of the fresh-water lens are ellipsoidal in form. According to the Ghyben-Herzberg principle, the lower surface extends below sea level to a depth equal to the height of the upper surface above sea level multiplied by the ratio of the density of fresh water to the difference between the densities of the fresh and the salt water. The fresh water is in constant motion toward the sea, and under steady-state conditions the foregoing expression for the depth of fresh water below sea level applies to conditions indicated by the upper and lower ends of an equipotential line rather than by a vertical line (Hubbert, 1940). The pattern of flow in a fresh-water body under a steady-state condition is shown in figure $9 \mathrm{~A}$.

Hubbert (1940, p. 925) pointed out that the upward movement of fresh water near the shore causes a greater thickness than the static ratio would indicate; however, in the central part of the island, downward movement of the water results in a thickness that is less than the static ratio would indicate in that area.

These relationships are complicated, however, by the fact that this dynamic system is seldom or never in a steady-state condition but is constantly changing in response both to seasonal changes in the rate of recharge of fresh water and to tidal fluctuations in the sea. 

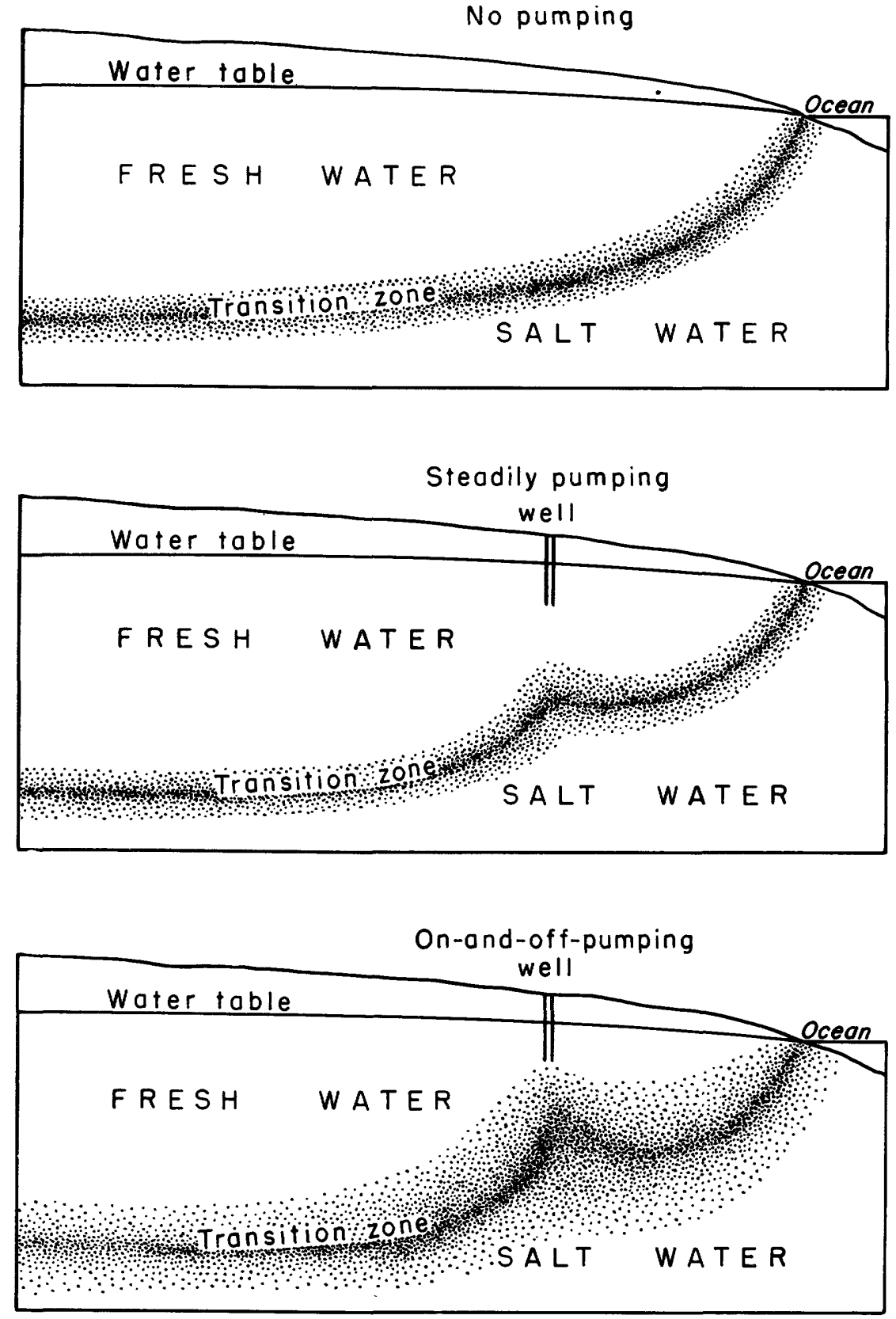

Figuro 8.-Schematic diagram showing effect of pumping on the thickness of the transition zone. 


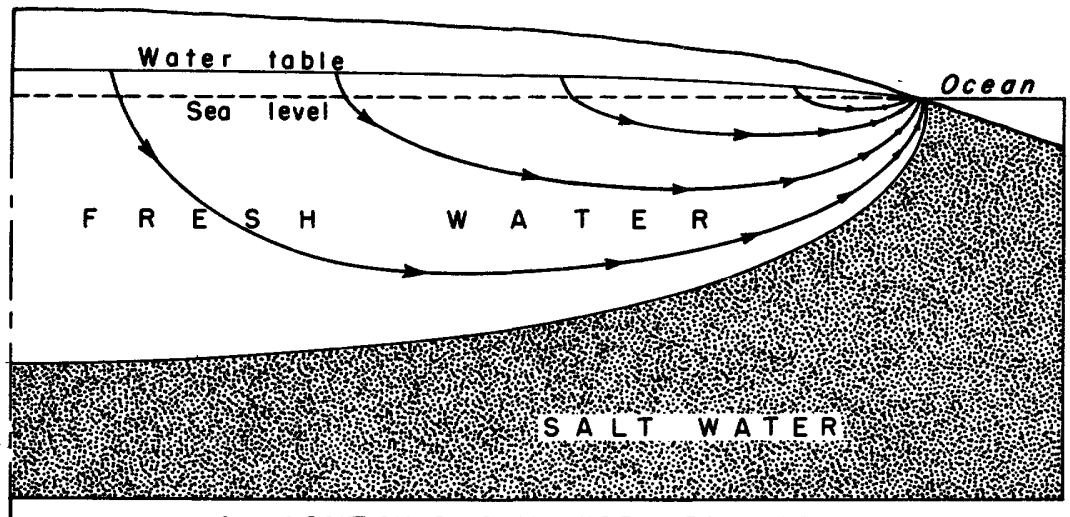

\section{A CONTINUOUS UNIFORM RECHARGE}
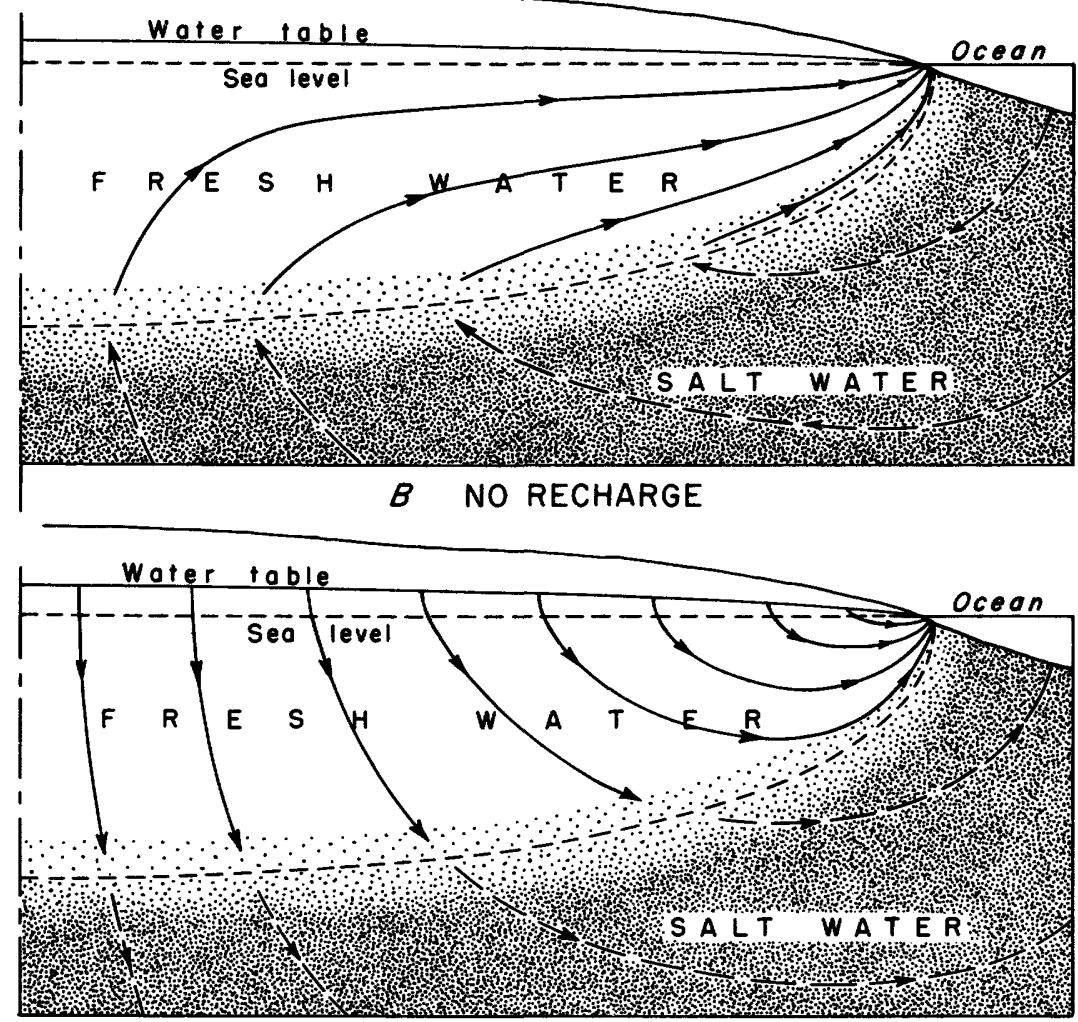

\section{INCREASING RECHARGE}

Figure 9.-Diagram showing half the cross section of an idealized elongate island in three different hydraulic conditions. $A$, Flow pattern for a steady-state condition of continuous recharge of fresh water. $B, A$ decaying lens not being recharged. $C, A$ thickening lens being recharged at an increasing rate. The dashed lines near the bottom of the fresh water represent the new position of the displaced interface. The arrows in $B$ and $C$ show the displacement of individual water partleles in both the fresh and salt water. The interface is continually shifting, and therefore neither the fresh nor the walt water crosses the interface. The height of the water table above sea level is exaggerated. 
The effect of changes in the rate of recharge on the height and depth of the fresh-water body relative to sea level is great. Under conditions of no recharge of fresh water, the fresh-water lens will decay as shown in figure $9 B$. As the lens decays, every unit decline in head, or height of the fresh water above sea level, is accompanied by about a fortyfold upward movement of the interface between the fresh and the salt water. Most of the water in a decaying lens, therefore, moves from storage toward the sea in the lower part of the lens, and the movement of fresh-water flow originates there instead of at the top of the lens, as in the steady-state condition shown in figure $9 \mathrm{~A}$. The upward component of movement that was present only at the edge of the lens now extends throughout almost the entire lens, and sea water moves into the island to replace the fresh water discharged during the thinning of the lens. (See fig. 9B.) Flow paths thus start at the floor of the sea, move in to displace the upward-moving interface, and then move outward to the sea again.

The potential gradient in this new flow system shown in figure $9 B$ modifies the shape of the lens and the positions of the surfaces relative to sea level. First, the upward component of movement throughout the lens causes a flattening of the upper surface of the lens and an increase in the thickness below sea level relative to that above. Added to this, however, is the greater effect in the same direction resulting from the lowering in potential under the lens that causes the sea water to move into the rocks of the island. This effect is especially pronounced if there are poorly permeable sediments on the floor of the sea. The lowering of potential in the sea water under the lens is reflected in a like lowering of the upper surface of the lens. Thus, potential losses in the sea water between the floor of the ocean and the bottom of the fresh-water lens may be the principal cause of the lowering of the upper surface of the lens during periods of no recharge.

Conversely, an increase in the rate of recharge will cause a thickening of the fresh-water lens and a seaward displacement of the salt water as shown in figure $9 C$. In addition to the circulation of salt water produced by thickening and thinning of the fresh-water lens, sea water must also continually move into the island to provide the salt-water component in the transition zone that is discharged with the fresh water at the margins of the island (Cooper, 1959).

Because of these factors, the height of the upper surface of the fresh-water body relative to mean sea level has, in itself, little practical value in determining the magnitude of changes in the thickness of the fresh-water body.

Abrupt changes in the hydraulic system such as increases in recharge from unusually heavy rainfall or major changes in the rate of artificial 
discharge of fresh water cause distortion of the lower surface of the fresh-water body. The amount and duration of these distortions depend largely on the rate that sea water can enter or leave the rocks of the island.

In figure 10 the solid lines show the position of the upper and lower surfaces of a stable fresh-water lens, and the dashed lines show the same lens after an abrupt increase in the rate of recharge to the central part of the fresh-water body, shown on the left side of the diagram. Recharge water added to the upper surface of the fresh-water body, shown in the left half of the diagram, increases the pressure on the lower surface and tends to displace it downward. This downward displacement causes an upward displacement of both the lower and upper surfaces of the fresh-water lens in the coastal part of the freshwater body. The salt water beneath the lens then has an increased potential relative to the sea that is equal to approximately the mean rise in the upper surface of the fresh water. This potential is gradually dissipated by movement of salt water into the sea, which results in a downward movement of the upper surface toward its original position and a downward movement of the fresh-salt water interface to a position lower than but approximately parallel to its position before the disturbance took place.

Local changes in fresh-water discharge have a similar effect. If, for-example, pumping of a well is stopped in one part of the lens, fresh water will move in to fill the cone of depression created by pumping. The localized increase in pressure on the salt water caused by the filling of this cone displaces the fresh-salt water interface downward in the vicinity of the well and displaces it upward in areas remote from the well. The consequent rise in the upper surface of the fresh water in areas remote from the well occurs much more quickly than if the adjustments took place in the fresh water alone. Aquifer tests in wells in the fresh-water lens tend to yield values for the coefficient of transmissibility that apply to the aquifer as a whole, irrespective of whether it is saturated by fresh or salt water. Values of the coefficient of storage calculated from aquifer test data tend to be higher than real values owing to the combined effects of movement of salt water into or out of the island and of the changes in the volume of saturated material.

The changes in the pattern of circulation and the attendant changes in potential could be measured and detailed through the use of a large number of piezometers in the fresh water and the salt water under the fresh-water lens. A piezometer in the sea water beneath the seaward edge of the lens could, for example, measure losses of potential in the sea water between this point and the floor of the ocean. A sec- 


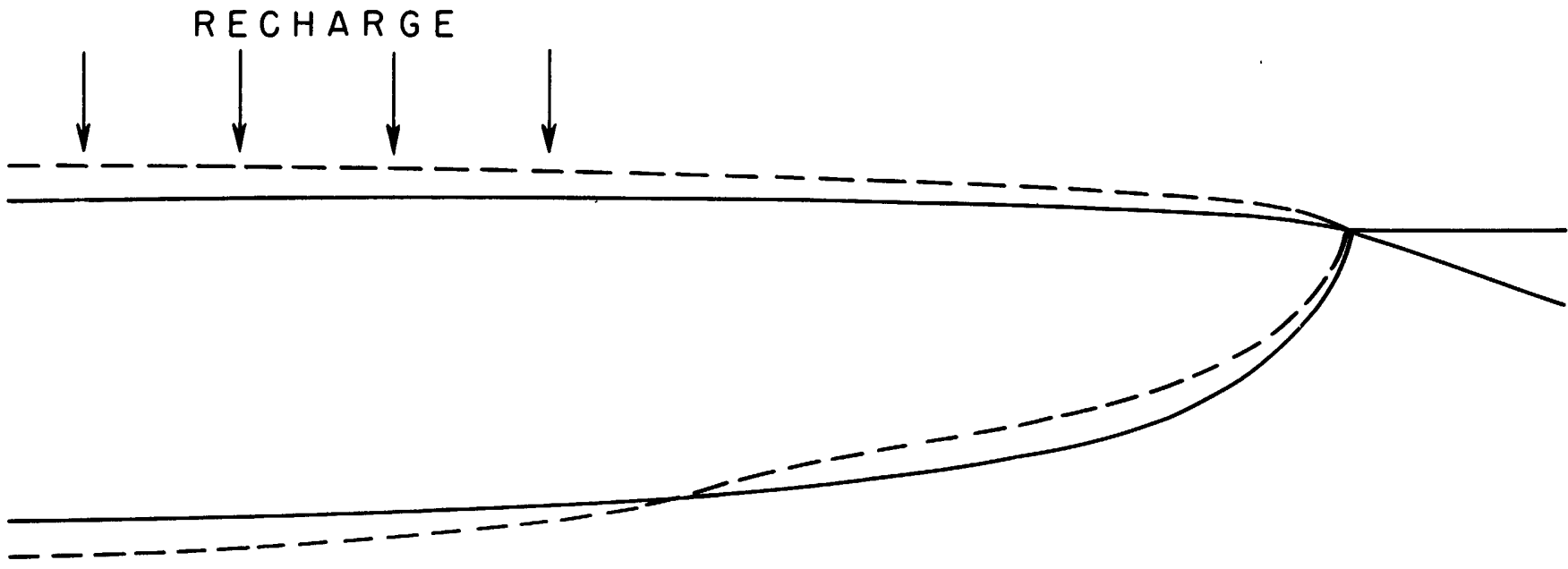


ond piezometer in the sea water farther inland would measure losses of potential in the sea water between the two piezometers, and so on throughout the sea water under the island. Another set of piezometers would provide similar information for the fresh water. If most of the losses of potential in the sea water occur at the floor of the ocean, much use can be made of data from a single salt-water piezometer and observation wells in the fresh water. By using the head measured by a salt-water piezometer as "sea level" and computing the lens thickness from the height of the fresh water above the level in the sea-water piezometer, the position of the fresh-salt water interface could be accurately determined.

The formula for computing the position of the interface below sea level is

$$
Z=h_{s}-\frac{\rho_{f}\left(h_{f}-h_{s}\right)}{\rho_{s}-\rho_{f}},
$$

where

$$
\begin{aligned}
& h_{f}=\text { head in the fresh water, } \\
& h_{s}=\text { head in the sea water, } \\
& \rho_{f}=\text { the density of the fresh water, and } \\
& \rho_{s}=\text { the density of the salt water. }
\end{aligned}
$$

This formula can be shown to be the same as equation 9 in Perlmutter and others $(1959$, p. 433) modified from Hubbert $(1940$, p. 864).

\section{DEVELOPMENT OF FRESH WATER}

In the development of a thick aquifer that can be drawn down safely below the level of points of natural discharge, the arrangement and size of the wells may be determined by economics rather than by hydrology. If for some reason the ground water cannot be drawn down below the level of natural discharge without harm, however, hydrologic considerations will also play a part in the size and location of the wells. In a fresh-water lens the lowering of the ground water below the level of natural discharge will tend to draw salt water into the aquifer. Therefore, an arrangement of wells is desirable that will intercept the fresh water without lowering the ground-water level below sea level.

A well near the seaward edge and in the thinnest part of a freshwater lens is capable of lowering the ground-water level to sea level at a lesser rate of pumping than a well farther inland. It therefore follows that the number of inland wells required to develop all the water in the lens would be less than the number of wells pumping an equal amount of fresh water near the shore. Thus, interception of the ground water moving through the lens to the shore could be through 
one of many possible lines of wells, the number and size of wells depending on the distance of the line from the shore.

In practice, a properly located line of wells should allow the recovery of most of the fresh water moving through the lens. The demand for water is generally seasonal, however, and it would be desirable, if possible, to make use of storage in the lens at times of heavy demand. Wells near the shore offer little opportunity for the use of storage, however, and it is desirable for the wells to be far enough inland to permit seasonal thinning of the lens without excessive increase in salinity in the wells.

The best system possible in most places might be a single line of wells lying between the area of recharge and the coast and far enough inland to permit seasonal changes in thickness of the lens without increases in salinity in the wells. However, a flow of fresh water past the wells toward the shore would continue except possibly during periods of very high demand. It should be possible to recover even this flow by the use of several lines of wells. During periods when water is going into storage, the line of wells nearest the shore could be used. When it became necessary to draw water from storage, pumping would be discontinued on the coastal wells and begun at the next line inland, and so on. This procedure should permit the maximum development of the fresh water in the lens.

The basal tunnel is a useful type of well in some places for developing water in the fresh-water lens. However, such a tunnel does not skim the fresh water only from the top of the lens. It sometimes is assumed that, because the water level in the tunnel is not pumped below sea level, only water above sea level can enter the tunnel. If this were so, water in the transition zone would not be drawn into the tunnel, and an increase in the salt content of water pumped from the tunnel would not occur. The salt content of the water from some tunnels, however, does indeed increase with draft. The tunnels that do not show an increase in salt content are those in lenses so thick that the pumping rate does not cause water from the transition zone to move up to the tunnel.

The effect of development on a thick lens and the quality of water produced from it is dependent on the amount of draft and is not significantly altered by the type of well used. If a well is in permeable rock in the fresh part of a thick lens, how far into the lens the well extends matters little provided it does not enter the transition zone. Thus, a tunnel at or near sea level in a thick lens has little or no hydraulic advantage over drilled wells producing an equal amount from the fresh part of the lens. The choice between drilled wells and tunnels in a thick lens is largely a matter of economics rather than hydraulics. 


\section{BASAL GROUND WATER IN SOUTHERN OAHU}

A well drilled in 1879 at Honouliuli in the arid land west of Pearl Harbor struck artesian water at a depth of about 220 feet. This well, which had a flow of about 60,000 gpd (gallons per day), was the first sucessful development of basal ground water in a drilled well in Oahu. Its success aroused great interest in wells as sources of supply and promoted drilling throughout the island. According to Wentworth $(1951$, p. 48), 104 wells had been drilled in the Pearl Harbor area and 94 in the Honolulu area by 1900 , and eventually more than 450 wells were drilled in southern Oahu. Construction of basal tunnels, or Maui-type wells, began in the middle 1930's (Stearns and Macdonald, 1940 , p. 8-31), and by 1950 about 10 of the tunnels were in operation in the Pearl Harbor and Honolulu areas.

The discovery of artesian water at Honouliuli was the beginning of the exploration and development of the great basal ground-water supply that underlies southern Oahu. This supply stimulated and sustained the planting of large areas of irrigated crops and the development of large urban, industrial, and military activities in the Pearl Harbor and Honolulu areas.

\section{EXTENT AND CHARACTER OF THE BASAL AQUIFER}

The great basal aquifer underlying southern Oahu extends westward from the southeast end of the island beneath the Honolulu and Pearl Harbor areas to the southern end of the Waianae Range. Its northeastern boundary in the Honolulu area is the edge of the dike system concealed in the Koolau Range. In central Oahu the northern boundary is the structural feature that impounds the high-level ground-water body under the Schofield plateau. The western boundary is in the southern part of the Waianae Range. On the southern side, the aquifer is overlain by coastal-plain deposits that form a caprock separating the aquifer from the sea.

Early in the development of the basal water, it was recognized that the water levels in artesian wells drilled into the aquifer in different parts of southern Oahu rose to different levels. These differences were the basis for separating the aquifer into several areas, each characterized by an artesian head higher or lower than that in adjacent areas. Palmer (1927) called these "isopiestic areas" and showed that in the Honolulu area they are separated by relatively impermeable fill extending far below sea level in ancient valleys. The ground-water areas, which have long been identified by numbers, are shown in figure 11. 
The basal aquifer consists of basaltic lava flows that have mostly high permeability. The lavas in the Honolulu area and in most of the Pearl Harbor area are composed of flows of the Koolau Volcanic Series. At the extreme west side of the Pearl Harbor area, the rock consists of basalt of the Waianae Volcanic Series. (See p. 13-15.) The lava flows extend thousands of feet below sea level and are permeable presumably to great depths.

The lava flows form a virtually continuous aquifer in southern Oahu, although the aquifer is divided into compartments, or isopiestic areas. The basal water head is greatest in area 2 in the central part of the Honolulu area (fig. 11) and decreases by steps eastward and westward. The head in each area depends on the amount of recharge, the height of the caprock and its ability to prevent seaward escape of the water, and the depth and character of the deep valley fills separating the areas.

The caprock has a crudely triangular prism shape and lies on the seaward sloping eroded surface of the permeable lavas. Its impounding effect on the basal water in the lavas is greatest in the central Honolulu area, where the basal heads are highest. Water in the part of the aquifer underlying the caprock is under artesian pressure. The water-level gradients in the ground-water areas in Honolulu are very low. In the Pearl Harbor area the water-level gradients are appreciable and can be shown by contour lines (fig. 11, areas 6 and 11).

\section{SOURCE OF WATER}

Rainfall in the Koolau Range is the principal source of the fresh basal ground water in southern Oahu. The Waianae Range, because of low rainfall, is an area of little recharge. Recharge in the rainy highlands is through the mantle of soil and weathered rock and through bedrock exposed or covered by thin permeable alluvium in the channels of streams. A large part of the recharge may enter temporary storage in dike compartments. In the Honolulu area some of the water in the high-level compartments discharges into streams, where a part of it flows into the sea without entering the basal reservoir. The channels of streams flowing into Pearl Harbor lie above the high-level reservoirs, and the mountain recharge enters the basal reservoir without appearing at the surface.

Large amounts of water are applied to fields overlying the basal aquifer in the area. Because of the generally high permeability of the soil, much of the irrigation water moves down past the root zone to the basal-water table. A part of the water applied to the fields is pumped from the basal aquifer and is recycled. The remainder is water imported from windward Oahu through the Waiahole Ditch Tunnel. 


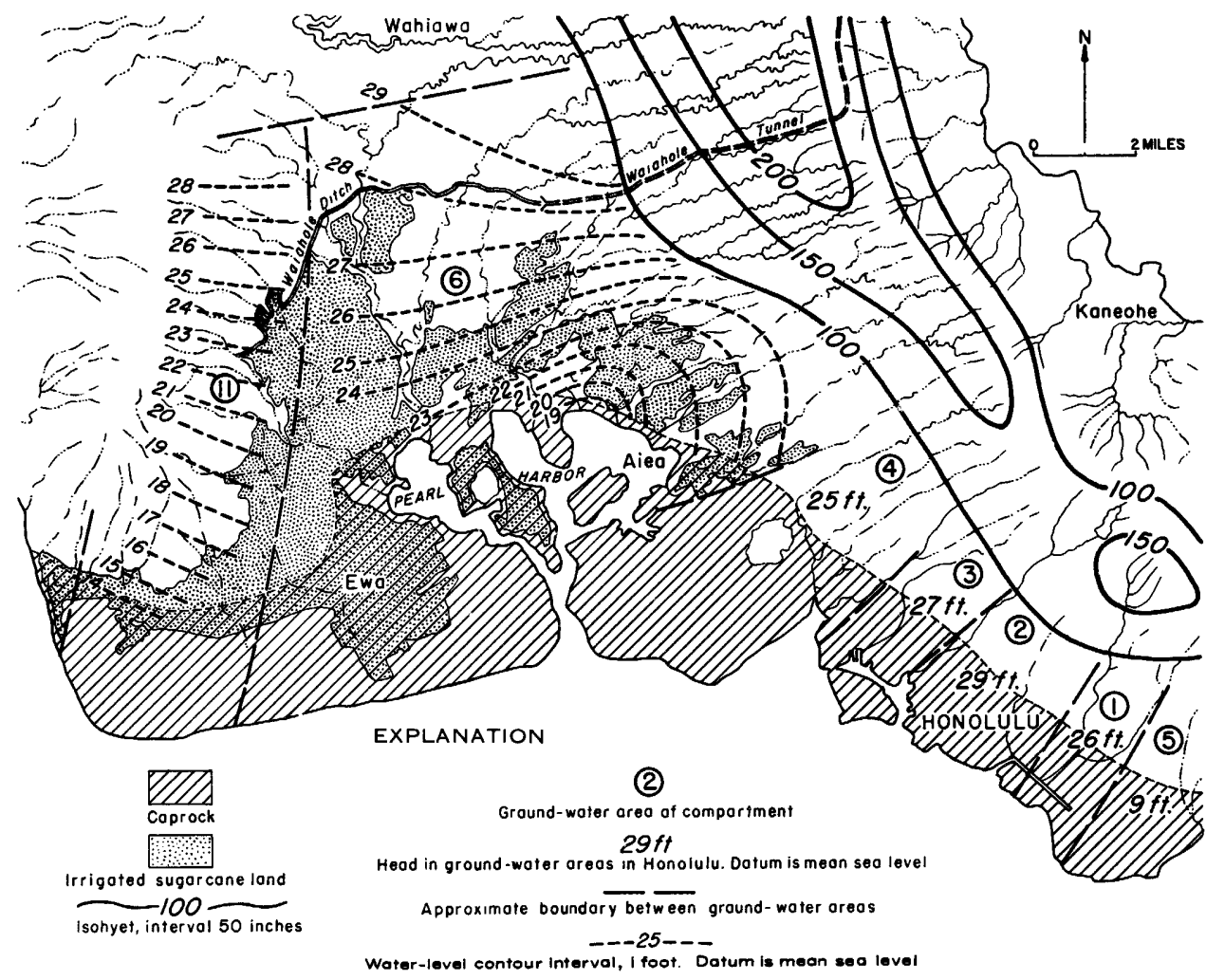

FIGORm 11.-Map of southern Oahu showing ground-water areas, the distribution of caprock, and the distribution of irrigated sugarcane land. The figures for heads in the Honolulu area and for water-level contours in the Pearl Harbor area show conditions on May 31, 1958, after a 4-month period when there was no pumping for irrigation. Ground water moves normal to the contour lines from areas of higher head toward areas of lower head. 
MOVEMENT OF THE BASAL WATER

Ground water moves from areas of recharge to places of discharge. The movement is in response to a difference in potential, or head, between the areas of recharge and the places of discharge. If the permeability of the aquifer is the same in all directions, the movement is at right angles to the lines of equal potential or head. If, however, the permeability is greater in one direction than in others, the movement may not be at right angles to the lines of equal head but may lie at some angle that favors the direction of highest permeability.

The contour lines on the water table shown in figure 11 imply the direction of movement of the ground water in the Pearl Harbor area as of May 31, 1958, at the end of a 4-month period during which sugarcane was not irrigated owing to a strike. The configuration of the water table shown by the contour lines probably approximates that existing under natural conditions before development of ground water in the area. If movement of water were at right angles to the contour lines, water recharging in the area of heavy rainfall on the Koolau Range east of Wahiawa would move along an arcuate path down to springs and wells near Pearl Harbor. The permeability of the aquifer, however, probably is greatest in the direction of dip of the lava flows that form the aquifer, and the dip of the flows probably is about at right angles to the trend of the Koolau Range. The actual path of movement of a particle of water, therefore, may be more nearly at right angles to the trend of the range than at right angles to the contour lines.

During periods of heavy pumpage for irrigation, the distribution of heads is probably considerably different from that shown in figure 11. The recharge from surface irrigation serves to balance some of the pumpage in the central part of the area, and heavy withdrawals in the western part of the area divert the flow to this region.

In addition to moving laterally, ground water also moves vertically. In areas of recharge the ground water also moves downward, and in areas where ground water is being discharged by springs or shallow wells, it moves upward from deep in the aquifer to the points of discharge. Because of these vertical components, the heads at wells drilled in areas of discharge will vary, depending on the depth of the well.

Ground water also moves between the various compartments in the aquifer. The movement may be under, around, or through the barrier.

\section{DISCHARGE}

PEARL HARBOR SPRINGS

Where basal ground water is not confined by a caprock, the normal discharge into the sea is along the shore at or slightly below sea level. 
This flow usually is so diffuse that it cannot be measured. In southern Oahu the seaward flow of the water is blocked by the caprock, and discharge takes place over the top, under the toe, or through openings in the caprock. Only the discharge above sea level at springs flowing over the top of or through openings in the caprock can be readily observed and studied. The only substantial visible discharge of basal ground water is near the shore of Pearl Harbor at springs whose flow probably includes most of the natural discharge of fresh basal water from areas 3, 4, and 6 . The natural discharge from areas 1, 2, 5, and 11 in the Honolulu area is unseen and is probably through the caprock below sea level.

Along the shore of Pearl Harbor over a distance of 5 miles from Aiea Bay on the east side of the harbor westward to the mouth of Waikele Stream, basal ground-water discharges into the harbor along a nearly continuous zone through breaks in the caprock. A similar discharge occurs east of the harbor in the channels of the lower courses of Halawa and Moanalua Streams. Ground water may also have escaped through the caprock on the west side of the harbor in the area between Waikele Stream and Honouliuli Stream before the basal head was lowered by pumping. The present zone of active discharge includes the five major Pearl Harbor springs at Kalauao, Waiau, Waimano, Waiawa, and Waikele. (See pl. 1.) The largest measurable ground-water flow occurs in these areas, but ground water also escapes along the shore in the intervals between the major springs and in the channels of streams that are cut below the basal water level.

The combination of a large water supply and flat fertile coastal land created an interest in the Pearl Harbor springs from the earliest settlement of the island. The early Hawaiians used the springs for cultivating wetland taro, and in some areas they impounded the flow in ponds where they raised fish. After the arrival of European and Oriental peoples, rice became the major crop and remained so for several decades until California-grown rice captured the local market. Today the chief irrigated crop in the spring areas is watercress, but a large amount of spring water is pumped to higher levels for sugarcane irrigation.

The earliest known description of the Pearl Harbor springs is in a report written in 1889 , which dealt with the water supply for irrigation of lands proposed for sugarcane cultivation (Schuyler and Allardt, 1889). The first artesian well was drilled in Oahu 10 years earlier, but not until about a decade later did the extensive well drilling take place that enabled the land to be used for sugarcane. At the time of the Schuyler and Allardt report, the basal head was probably 
about 30 feet. Schuyler and Allardt, impressed by the large volume of water discharging from the springs, wrote:

Our attention was first called to the springs that burst out from the foot of the low bluffs along the margin of the semi-swamp lands of Pearl Harbor, and we cannot here refrain from expressing our surprise and astonishment at their phenomenal volume and extent. They furnish a supply for irrigating some 2,000 acres of rice fields and a large area cultivated to bananas and taro, and in addition such large quantities go to waste, or at most are only used to furnish water power to various rice mills, that strong streams navigable for small hoats, pour continually into the bay.

It is owing to this great supply of fresh water that Pearl Harbor doubtless owes its existence, and the coral insect has been kept from closing its entrance.

The largest and strongest streams come from the bluff at a height of 20 to 25 feet above the tide level, and from this height all the way down to sea level the slopes for miles are like a great sponge-full of water, oozing out in a myriad of little streams. Even in the bay beyond the shore, springs break out so strongly that it is said cattle and horses have been seen to wade out to them, plunge their nose under the salt water and drink from the fresh fountains bubbling up from beneath.

Schuyler and Allardt proposed that the water be collected and pumped to the areas marked for cane growing. Although they did not recognize that the occurrence of fresh water along the coast was the result of fresh water floating on salt water, they did suggest that the springs were overflow from an artesian basin through seams and crevices in a sedimentary caprock. Several decades later Palmer (1927, p. 43) suggested that the Pearl Harbor springs resulted from the escape of ground water from a Ghyben-Herzberg lens where the caprock is relatively low. Stearns and Vaksvik (1935, p. 368) agreed with Palmer but added specifically that the springs represent the escape of artesian water; they pointed out that the discharge varies directly with static level in adjacent artesian wells. Wentworth (1945, Honolulu Board of Water Supply, unpublished data), however, did not consider the springs to be artesian. He called them "side-hill" springs that discharge water from the surface of the free water table through exposed permeable rock. The results of the present investigation show that the springs are artesian.

The zone of springs along Pearl Harbor is restricted to the narrow strip lying between the inland edge of marine sediments in the caprock and about 20 feet above sea level. This zone overlies the artesian portion of the ground-water system.

The rocks in the area of the springs consist of basalt of the Koolau Volcanic Series, weathered basalt at the inland margins of the spring zones, and caprock overlying basalt in the seaward part of the zones. The caprock includes only terrestrial sediments and weathered basalt. Marine sediments and pyroclastic materials are absent in the zones of discharge. 
The main spring discharge occurs at the inland edge of the caprock where the basalt is exposed in a break in slope of the land surface. Water also emerges seaward of the break in slope, through the thin caprock of the coastal plain but in less volume than from the exposed basalt. At the excavation for a new unit of the Hawaiian Electric Co. power plant at Waiau, spring flow came from a zone where a basalt spur at a level below the regional head was stripped of its caprock cover. The largest individual flows come from sections of weathered aa lava, and many seeps come from weathered pahoehoe lava (fig. 12). This manner of discharge is typical of the flow from basalt in the major spring areas.

The terrestrial sediments of the coastal plain near the springs consist of both younger alluvium deposited by coalescing deltas during and subsequent to the Waimanalo stand of the sea and older alluvium that was deposited before the Waimanalo stand. A soillike layer derived in place from basalt is typically found below the older alluvi-

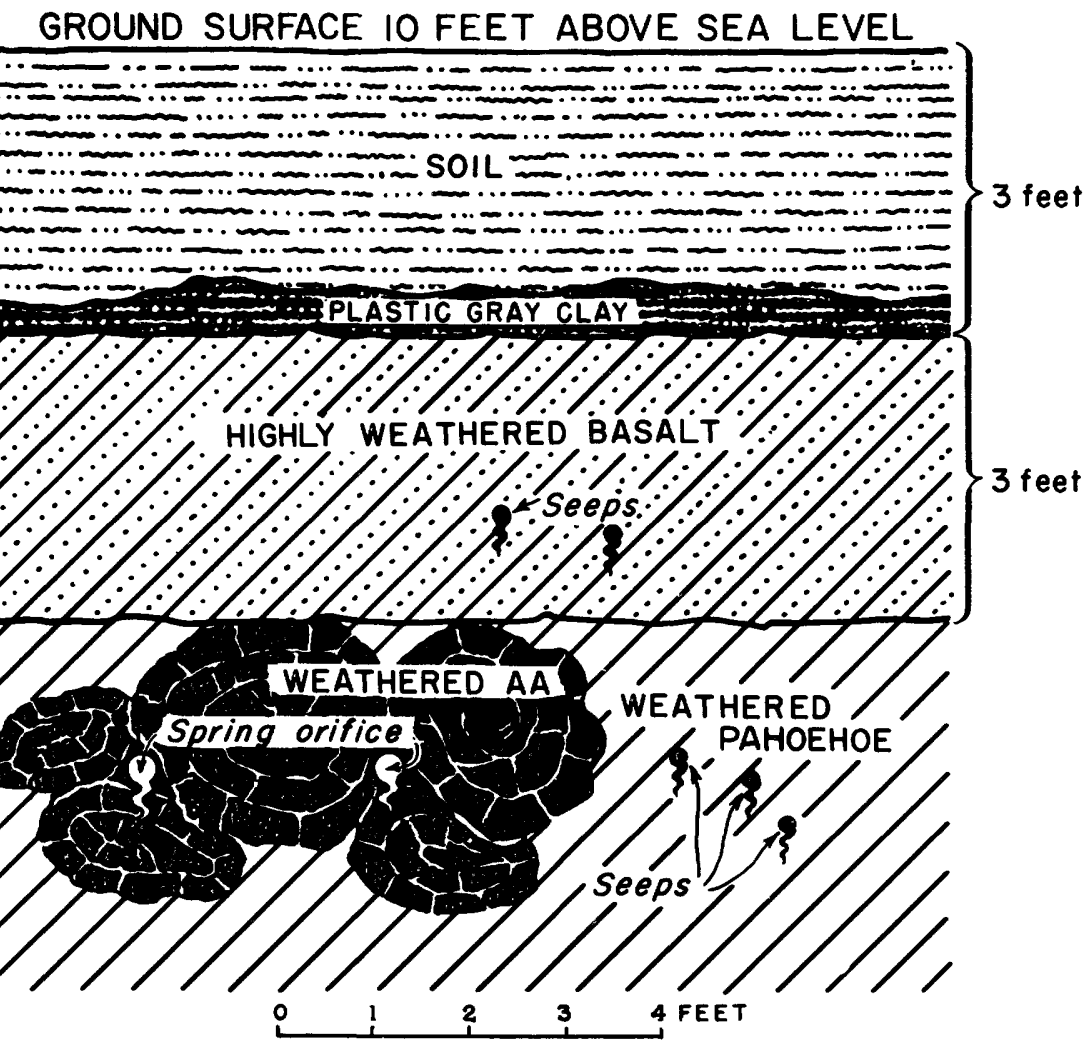

Figure 12.- Section of the caprock in the Waiau springs area showing the nature of the flow of water from the basalt. 
um, and underlying this layer is a section of weathered basalt that grades downward into the fresh basalt of the aquifer. This sequence is shown in the log of test hole $\mathrm{T}-67$, which follows.

Log of test hole T-67

[Alt, $5 \mathrm{ft}$ above sea level]

\begin{tabular}{|c|c|c|}
\hline Description & $\begin{array}{c}\text { Thickness } \\
\text { (feet) }\end{array}$ & Depth (feet) \\
\hline $\begin{array}{l}\text { Younger alluvium: } \\
\text { Upper part: silt and mud, black, grading into coarse } \\
\text { particles of mud and weathered rock; contain shell } \\
\text { fragments. Weathered rock fragments and mud } \\
\text { in lower part. } \\
\text { Older alluvium: } \\
\text { Mud, brown to light-brown, and coarse particles of } \\
\text { thoroughly weathered rock. Individual pebbles of } \\
\text { weathered rock common } \\
\text { Soillike layer of weathered basalt: } \\
\text { Mud, reddish-brown, grading into mud containing } \\
\text { rounded rock fragments. Unweathered rock frag- } \\
\text { ments mixed with weathered fragments in lower } \\
\text { part. } \\
\text { Thoroughly weathered basalt: } \\
\text { Mud, brown, with rock fragments } \\
\text { Intercalated layers of hard and soft rock; solid layer } \\
\text { at } 91 \text { ft. No artesian flow above } 91 \mathrm{ft} \text {. At } 92 \mathrm{ft} \text {, } \\
\text { partial artesian flow and head of } 7 \mathrm{ft} . \\
\text { Partly weathered basalt: } \\
\text { Alternating layers of hard and soft rock. Fresh olivine } \\
\text { grains common. Partial artesian flow } \\
\text { Hard rock. At } 143 \mathrm{ft} \text { full artesian flow and head of } 18 \mathrm{ft} \\
\text { Unweathered basalt: } \\
\text { Lava flows, pahoehoe, aa, and clinker }\end{array}$ & $\begin{array}{r}46 \\
5 \\
1,159\end{array}$ & $\begin{array}{r}92-138 \\
138-143 \\
143-1,302\end{array}$ \\
\hline
\end{tabular}

The average discharge of the Pearl Harbor springs during the period of record has been about $80 \mathrm{mgd}$. Records of flow at most of the springs go back to 1931, except at Waikele Springs, which were not gaged until 1951. Flow records at Waimano Springs are complete to 1937, when construction of a power plant at the springs and the use of much of the water by the plant made measurement of the total flow impossible. The flow at Waiau Springs is also used by the power plant and is included with that of Waimano Springs.

The flow of the springs varies with the head in the aquifer. For the period of record, the flow at each of the springs was plotted against the head at well 193. The plotted data for each fell in an approximately straight line. The resulting curves are shown as solid lines in figure 13. Dashed extentions of the curves are used to estimate the flow at heads for which data are not available. The extensions are only approximate; the upward extension would have a 


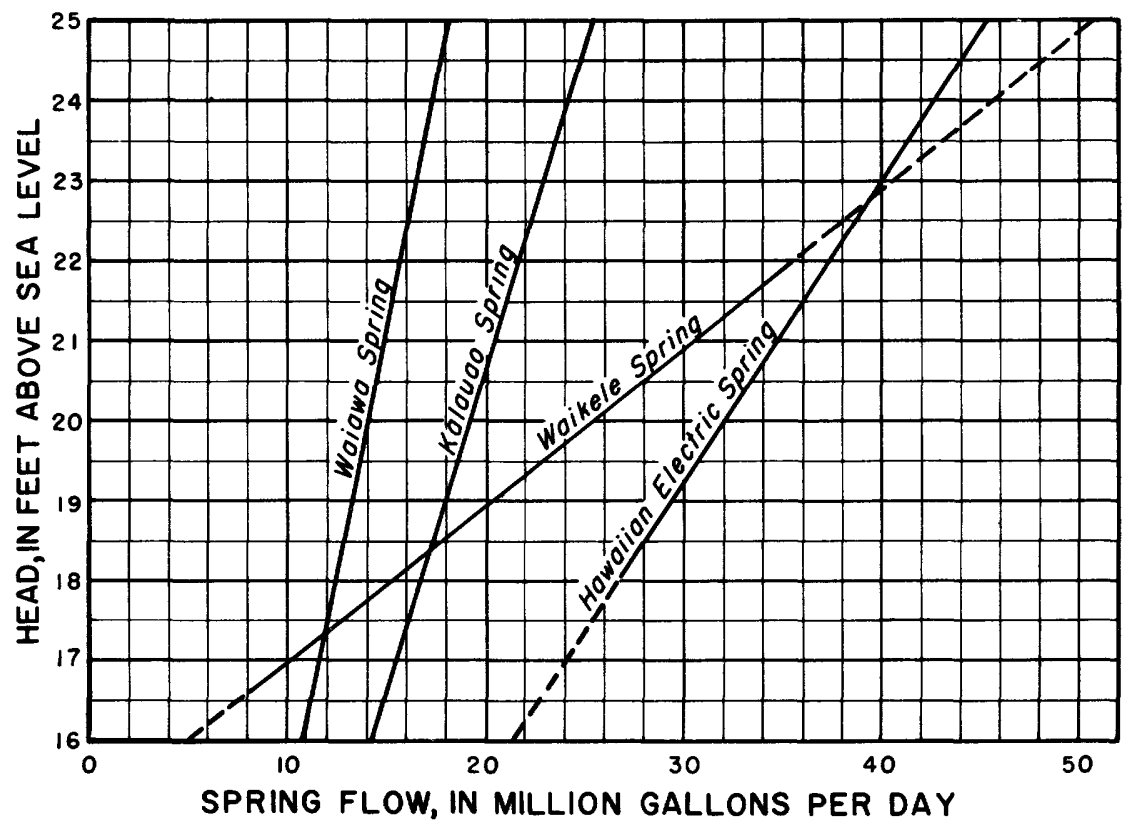

FigURE 13.-Graph showing the relationship of the head at well 193 to the flow from the Pearl Harbor springs.

flatter slope if higher spring orfices started to flow, and the lower extension would become -steeper if spring orifices stopped flowing. On the basis of these curves, the flow of the springs can be estimated for various periods and dates. Table 1 shows several such estimates before diversion and also the minimum flow after diversion in September 1954.

TABLE 1.-Flow of Pearl Harbor springs at various times, in million gallons per day [Based on head-discharge relations shown in fig. 13]

\begin{tabular}{|c|c|c|c|c|}
\hline \multirow[b]{2}{*}{ Spring } & \multicolumn{3}{|c|}{ A verage flow } & \multirow{2}{*}{$\begin{array}{l}\text { Minimum } \\
\text { flow after } \\
\text { diversion by } \\
\text { pumping, Sep- } \\
\text { tember } 1954\end{array}$} \\
\hline & $1953-57$ & $\begin{array}{c}\text { February } \\
1937\end{array}$ & $\underbrace{\text { September }}_{1954}$ & \\
\hline $\begin{array}{l}\text { Kalauao } \\
\text { Waiau-Waimano } \\
\text { Waiawa } \\
\text { Waikele }\end{array}$ & $\begin{array}{l}19 \\
32 \\
14 \\
22\end{array}$ & $\begin{array}{r}25 \\
45 \\
18 \\
151\end{array}$ & $\begin{array}{r}15 \\
122 \\
11 \\
7\end{array}$ & $\begin{array}{r}8 \\
110 \\
7 \\
6\end{array}$ \\
\hline Total & 87 & 139 & 55 & 31 \\
\hline
\end{tabular}

1 Estimate based on extension of curve. May be less than actual flow. 


\section{DESCRIPTION OF MAJOR SPRINGS}

Five major springs discharge along a slightly arcuate line trending westward near the shore at the heads of the lochs of Pearl Harbor (pl. 1).

KALAUAO SPRINGS

Kalauao Springs is located in a crescent shaped alluvial flat about 5 acres in area at the base of a break in the gentle slope of weathered basalt on which sugarcane is grown. Watercress and lesser amounts of lily root and taro are grown in irrigated patches on the flat.

The northern boundary of the Kalauao Springs area is sharp and trends westward along the low bluff in the basalt from which the main discharge occurs. The highest visible orifice during periods of low head is at an altitude of about 15 feet. Southward toward the harbor, the orifices give way to seeps rising through alluvium and to marshy land near the shore. The main spring orifices discharge into ditches that flow into a major channel that leads to the harbor. The distance from the coast to the northernmost orifices is about 1,700 feet; however, most of the discharge takes place at the break in slope and in the cultivated area between Kamehameha Highway and the northern boundary, a distance of about 800 feet. The maximum width of the spring area is about 800 feet.

WAIAU SPRINGS

The Waiau Springs area lies a mile west of the Kalauao Springs. The spring area is divided into two parts by Kamehameha Highway, which forms a dam that impounds flow from springs north of the highway. Two culverts through the highway embankment carry flow from the pond into a cultivated area south of the highway. Most of the spring water rises in the area north of the highway from orifices in basalt exposed in the break in slope and in the pond, which covers about an acre. The highest orifices in the basalt are 11-12 feet above sea level, but seeps are found as high as nearly 17 feet during periods of high head. The discharge from each orifice in basalt above the level of the pond is several thousand gallons per day. However, the flow from the pond to watercress fields south of the highway is several million gallons per day, and much of the water undoubtedly flows from orifices submerged by the pond. All water from Waiau Springs eventually flows into a single channel and is used by the Hawaiian Electric Co. at the Waiau power plant.

\section{WAIMANO SPRINGS}

The Waimano Springs area lies 2,000 feet west of Waiau Springs and is separated from them by a spur on which a power generating plant is located. This spring area includes the sometimes separately 
named Kalauoopu, Lokokukona, and Puukapu Springs, all of which are within the discharge area.

Most of the water from Waimano Springs is diverted to a storage reservoir that serves the Waiau powerplant of the Hawaiian Electric Co. Additional water for the plant is obtained from artesian wells drilled in the spring area and from discharge within the confines of the plant area. After it is used in the plant, the spring and well water flows into Pearl Harbor or is pumped to irrigated sugarcane fields of the Oahu Sugar Co.

The Waimano Springs area is divided in two sections by an old railway embankment. The upper section is roughly a rectangle 800 by 200 feet, with the long axis trending eastward. The lower section is about 1,000 by 300 feet, with the long axis trending northward. All the large orifices are in the upper section at the break in slope where basalt is exposed. Seaward of this break is a cultivated alluvial area in which watercress is the principal crop. The highest orifice is about 14 feet above sea level, and the average altitude of the upper orifices is about 8 feet. In the flat part of the upper section and throughout the lower section, water rises in seeps through the thin alluvial caprock. The seaward half of the lower section is a swamp.

WAIAWA SPRINGS

The Waiawa Springs area is on the west side of the Pearl City Peninsula and 11/4 miles west of the Waimano Springs. The area is low and flat. About 50 acres are inciuded in the area, but the active springs are in an area of about 25 acres. Within the flat alluvial part a variety of water-loving plants, chiefly watercress, is grown, but a large part of the area is swampy. At the northern edge the altitude of the highest known orifice is about 11 feet above sea level, or about 7 feet below the basal-water level. Most of the water flows from orifices in basalt exposed along the northern boundary. A considerable amount also issues through alluvium in the swampy and cultivated part, although the quantity is relatively small at any one point.

\section{WAIKELE SPRINGS}

The Waikele Springs are the westernmost of the active springs along the Pearl Harbor coastal plain. They lie 2 miles west of Waiawa Springs and discharge in the channel and on the flood plain of the Waikele Stream near the town of Waipahu. The principal discharge points of the Waikele Springs are at the base of the break where the slope meets the flat alluviated valley of the stream. The highest known orifice is about 14 feet above sea level. Additional water escapes through the flood plain sediments and in the stream channel. 
WELLS

In the first two decades (1879-1900) of development of ground water in southern Oahu, water was used mainly in the lowlands, where the needs could be supplied by flowing artesian wells drilled through the caprock into the basal aquifer. Beginning about 1900, batteries of deep wells equipped with large-capacity steam-driven suction pumps were installed in the coastal plain and at low altitudes in the bottoms of valleys, and the cultivation and irrigation of sugarcane in the Pearl Harbor area expanded to higher lands. Because of the thickness of the caprock and the depth to which the impermeable zones extend below the valley floors, many of these wells entered permeable rock hundreds of feet below sea level, in the zone of transition between fresh and salt waters. Irrigation water from the deep wells in the Pearl Harbor area is augmented by water pumped from the large springs on the shore of Pearl Harbor and, since 1913, by water transported through the Waiahole Ditch Tunnel (fig. 11) from windward Oahu.

Beginning in the 1930's, several shafts or basal tunnels were constructed to supply water for irrigation and for municipal and military use. From points as high as 300 feet above sea level and as far as 3 miles inland, vertical or inclined shafts were sunk nearly to sea level, and horizontal tunnels were driven as much as 1,200 feet at about sea level. Their construction was expensive even in the 1930's, and a large yield had to be presupposed to justify this initial cost. Several of the shafts are equipped with pumps that discharge 10 to $30 \mathrm{mgd}$. During this period of development, the owners and operators of large wells worked together for management of the ground water reservoir based on scientific studies and technical advice.

Total pumpage in the Pearl Harbor area increased from less than $20 \mathrm{mgd}$ in 1901 to $165 \mathrm{mgd}$ in 1912 , which is close to the average rate of pumping during the 45 subsequent years (fig. 4). The introduction and construction of large-capacity shafts in the past 20 years did not result in a large overall increase in pumpage.

\section{AQUIFER PROPERTIES}

The capacity of an aquifer to transmit water is termed "transmissibility." The coefficient of transmissibility is expressed by the Geological Survey as the number of gallons of water per day at the prevailing water temperature that is transmitted through each mile strip extending the full saturated thickness of the aquifer under a hydraulic gradient of 1 foot per mile. The coefficient of storage is the amount of water produced by a vertical column of the aquifer having a base of 1 square foot when the ground-water level is lowered one foot. Under water-table conditions, it is the water that is yielded 


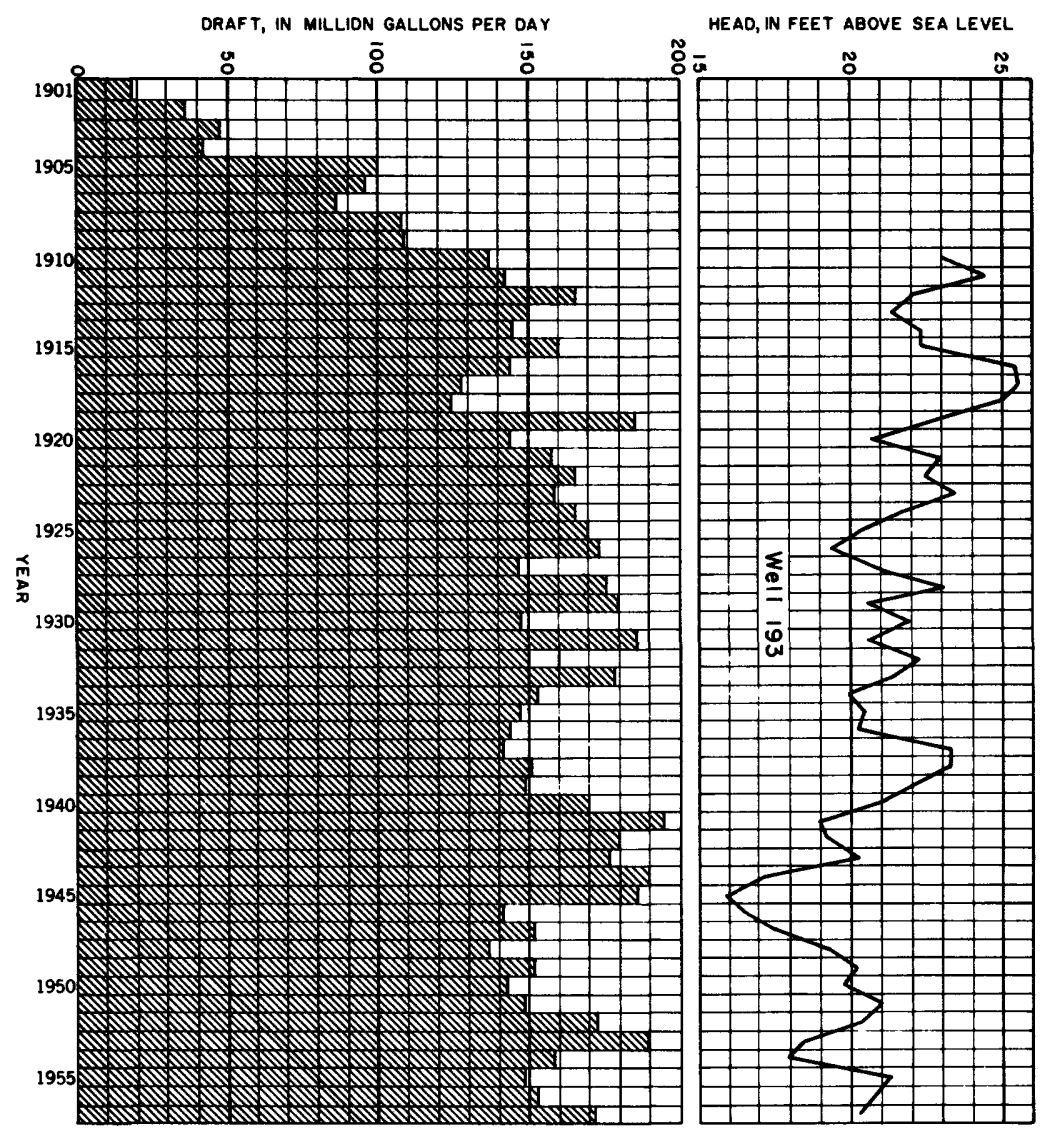

Figore 14.-Graph showing the head at well 193, 1910-57, and average daily pumpage from the Pearl Harbor area (areas 6 and 11), 1901-57. The flow from springs and wells is not included.

by the lowering of the air-water interface. The rise of the salt-fresh water. interface also yields water, but it is not known whether the amount is the same as that yielded by the movement of the air-water interface.

Values of the coefficients of transmissibility and storage of the aquifer in southern Oahu were obtained by an adaptation of the standard aquifer-test procedure using the Theis nonequilibrium formula (Theis, 1935, p. 87-89). This procedure involves the evaluation of the drawdown and (or) recovery of ground-water levels in response to uniform pumping or the cessation of uniform pumping. The data used were the records of recovery of the ground-water level due to the cessation of pumping for sugarcane irrigation at the start of the sugar strike of 1958 and records of the drawdown of the water level when pumping was resumed after the end of the strike. As pump- 
ing at all wells started and also stopped at about the same time, records for the local and regional centers of gravity of pumping were used rather than those for individual wells. Those for observation wells that were 5,000-6,000 feet from a local center of gravity of pumping proved to be the most useful. Attempts to use data for the regional center of gravity of pumping were not successful. The values used in the computations were the average daily water levels taken from recorder charts during the first 7 days after pumping stopped and the first 18 days after pumping resumed. The drawdown data gave more usable results than the recovery data.

The coefficients of transmissibility of the aquifer, as computed at four observation wells, were $4.3 \times 10^{6}, 4.4 \times 10^{6}, 4.4 \times 10^{6}$, and $4.6 \times 10^{6}$ gpd through each strip extending the thickness of the aquifer under unit gradient. The close agreement of the values suggests that the results are valid.

The coefficients of storage for the four wells were $4,4,5$, and 6 . This range of values is expected in this type of evaluation. The values are considered to be reasonable.

\section{WATER-LEVEL FLUCTUATIONS AND CHANGES IN STORAGE}

Ground-water levels rise during periods when recharge exceeds discharge and fall when discharge exceeds recharge. As a result, water levels in Oahu generally rise during the winter and drop during the summer. The annual fluctations in the Pearl Harbor area range from 3 or 4 feet in wells near the north shore of East Loch of Pearl Harbor to 6 or 8 feet in wells west of West Loch.

At the time of the first development of basal water in Honolulu in 1880, the head in area 2 was 42 feet above sea level. The heads in areas 1, 3, and 4 were not recorded at an early date but appear to have been somewhat lower than 42 feet. Subsequent development for domestic, irrigation, and municipal use, coupled with a drought, resulted in the heads being lowered to 18 feet in area 1 and to 23 or 24 feet in areas 2,3 , and 4 by 1926 . The return of normal precipitation and some reduction in draft resulted in a rise of about 5 feet in 5 years. During 1931-58, except for a period of heavy draft during World War II, heads have fluctuated largely in response to rainfall. The alltime record lows for most of the wells in southern Oahu occurred during World War II. These lows included a head of 14.6 feet at well 193 in area 6 in 1945, and a head of 22 feet in area 2 in 1946.

In an investigation of relationships between the potentials in the fresh water and in the sea water underlying the fresh water, test hole T-67 was drilled near the shore and a piezometer was placed in the salt 
water at a depth of about 1,300 feet below sea level. The water at 1,300 feet is slightly less saline and warmer than sea water; it therefore has a specific gravity less than sea water (1.0215 as compared to 1.0255). The salt-water level in the piezometer fluctuated near sea level in a pattern nearly identical to that in the fresh-water levels in wells in the area, which were fluctuating between $181 / 2$ and $211 / 2$ feet. In April 1958 the head at T-67 was 3.05 feet above sea level, and at well 193 it was 21.38 feet. From equation (1), page 29, the theoretical position of the interface between fresh and salt water in feet below sea level was

$$
\begin{aligned}
z & =\frac{0.9980}{1.0215-0.9980}(21.38-3.05)-3.05, \\
& =42.46(21.38-3.05)-3.05, \\
& =775 \text { feet below sea level. }
\end{aligned}
$$

The subsequent record from the test hole has not given conclusive information on the manner in which the lens thickens and thins.

Owing to uncertainties regarding the area of the aquifer, the value of the storage coefficient, and the movement of the bottom of the fresh-water lens, changes in storage cannot be determined with adequate precision. The amount of storage however, is indicated by the effect of pumping on the water levels. The seasonal fluctuation may be as much as a third of the average head, indicating a substantial but apparently safe temporary annual depletion of storage.

Another indication of the magnitude of storage is the length of time required for water levels to adjust fully to long-term changes in rainfall. The time lag is about 9 months in the main aquifer in southern Oahu (fig. 15).

\section{TRANSITION ZONE}

In the Pearl Harbor area of southern Oahu, the transition zone between fresh and salt water is thickest in the relatively sluggish part of the lens, which lies on the seaward side of the main line of springs discharging along the shore of Pearl Harbor. Most of the fresh water discharges at the large springs near the shore and from wells inland from the springs, and the movement of fresh water in the part of the aquifer below the caprock seaward of the springs is relatively small.

During the present investigation, the nature of the transition zone in the part of the lens seaward of the Pearl Harbor springs was explored during the drilling of test hole $\mathrm{T}-67$. The hole was drilled to a depth of 1,300 feet below sea level on the shore near the Kalauao Springs. Samples from various depths were analyzed for chloride content, which is used as the index for measuring sea-water intrusion. 

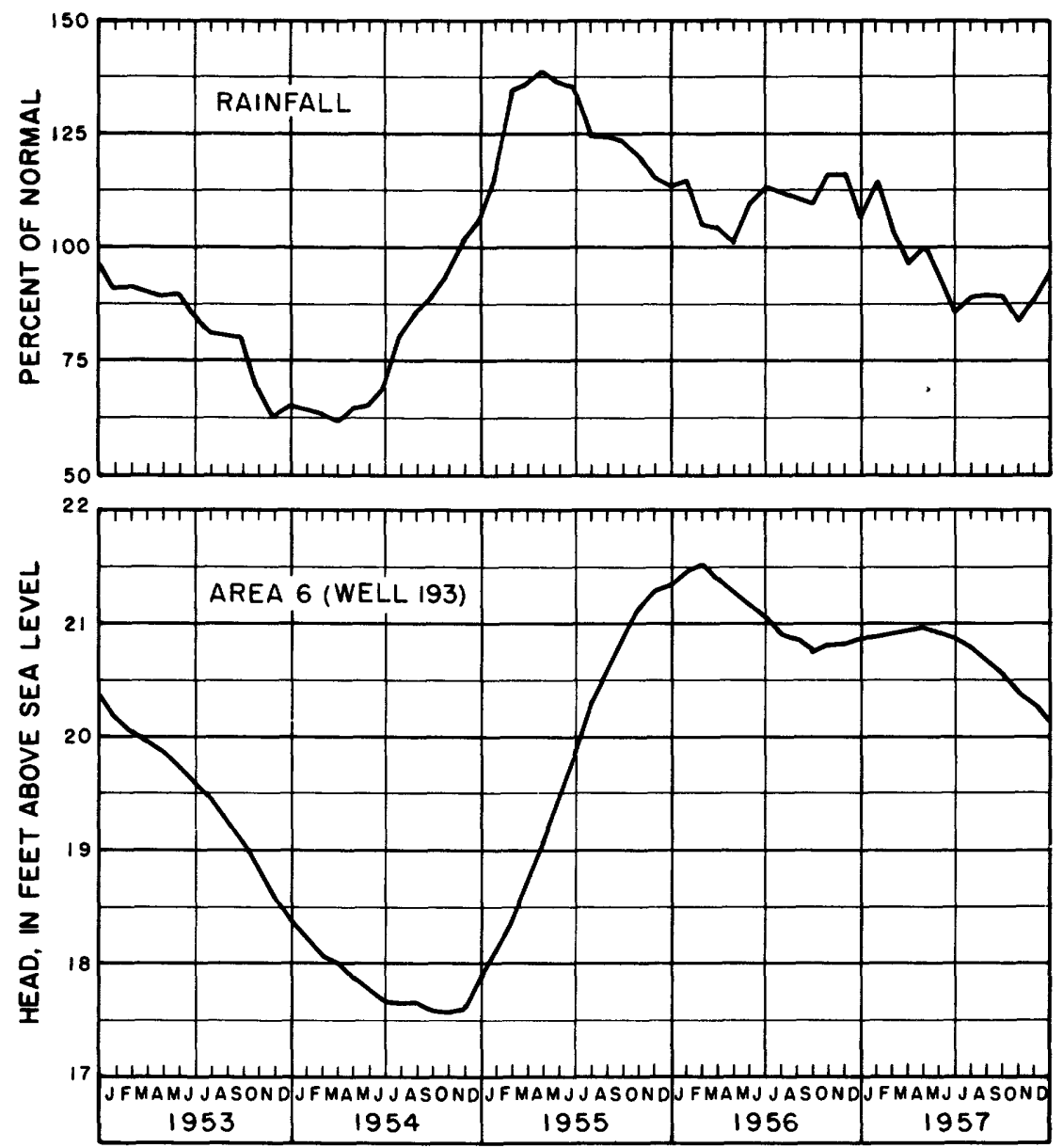

Frgury 15.-Graphs showing the 12-month moving average of the head at well 193 and the 12-month moving average of rainfall, in percentage of normal, at 9 gages in the Koolau Range in the Honolulu area.

The samples were obtained by sealing off the chosen depths and permitting free artesian flow or pumping at about $10 \mathrm{gpm}$ (gallons per minute) at depths where artesian flow failed. Concentration of the chloride content is roughly sigmoidal with depth (fig. 16). In this area the lens consists entirely of transition-zone water, the freshest part having $800 \mathrm{ppm}$ (parts per million) of chloride (about 4 percent sea water).

A similar situation may prevail also near the shore in Honolulu. Well 101, at the edge of the Honolulu harbor in area 2, is 1,141 feet deep. The long-term average head in this area is 28.21 feet. Analyses were made of samples of water from the well during a 5-month period, 


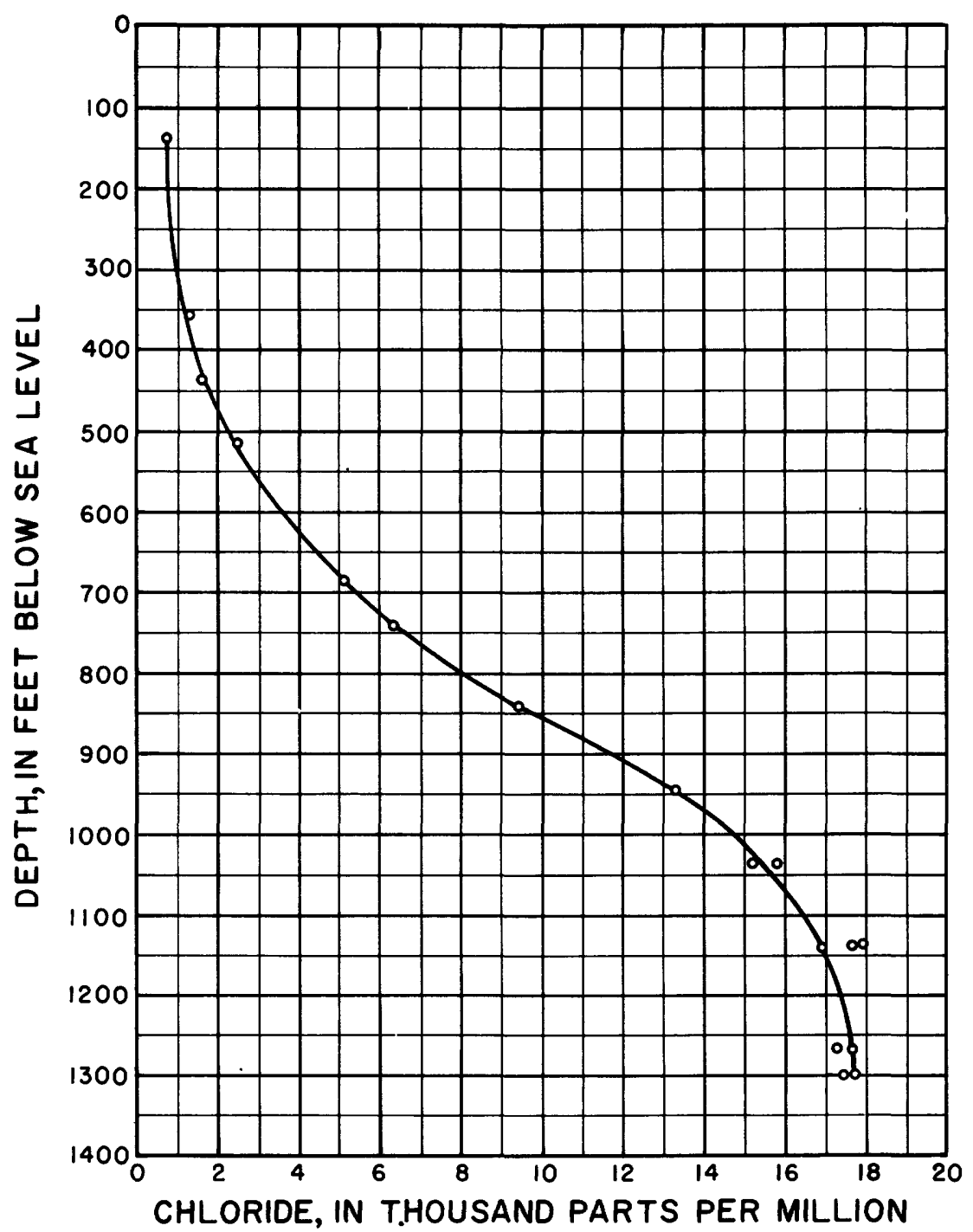

FIGURE 16.-Graph showing change in chloride content of water with depth in test hole T-67.

May to September 1950, by the Honolulu Board of Water Supply. At 1,023 feet below sea level, the average chloride content of 52 samples was $9,070 \mathrm{ppm}$, and at 1,101 feet the average of 10 samples was 9,190 ppm. The depth of 1,100 feet is near the theoretical bottom of the lens (1,128 feet), as computed by use of the Ghyben-Herzberg ratio, and the chloride content approaches half the sea-water chloride concentration. 
In the part of the lens containing large quantities of fresh water, the structure of the transition zone may differ considerably from that of the more sluggish and saline parts. Under steady-state conditions, a sharply defined interface between the fresh and salt water would be possible (Glover, 1959). However, under natural conditions, because of fluctuations in recharge and discharge and the stresses caused by tides and pumping, a transition zone will occur, but the vertical concentration curve will be greatly flattened owing to the large quantities of fresh water flowing in the system. Although the transition zone may be comparatively thin, the point where the salinity is half that of sea water will likely be at a depth equal to about 40 times the head above sea level. The chief effect of the fluctuating but continuous flow of fresh water through the lens would be to distort the limit of concentration, which is shown on the part of the curve that is asymptotic to the concentration of fresh water. The high concentration limit would probably be parallel to the upper limit determined in test hole $\mathbf{T}-67$.

\section{DVOLUTION OF THE TRANSTTION ZONE}

Before the development and pumping of basal ground water began in southern Oahu, the transition zone was generated by contraction and expansion of the lens resulting from fluctuations in recharge and discharge and from movement of the water caused by tides. The effect of tidal motion is greatest at the coast and decreases abruptly inland. In an unconfined lens typical of many small Pacific islands, tidal effects can prevent the formation of a fresh-water core (Wentworth and others, 1955); but in a lens as extensive and as thick as that of southern Oahu, these effects cause relatively little dispersion. This is especially true in Oahu, where the average tidal fluctuation in the ocean is only about 1.88 feet.

Fluctuations in recharge and discharge can lead to substantial movements of water over the entire extent of a lens and to the formation of a widespread transition zone. Periods of drought and of high rainfall are common on Oahu, and their occurrences cause thinning and thickening of the lens. The resulting dispersion is probably restricted to a relatively thin zone, however, because the distance moved by the interface between the salt and fresh water is small in comparison with the total thickness of the lens. Catastrophic thinning of the lens is unknown in historic times. Before the development and pumping of ground water began in southern Oahu, a thin transition zone probably existed in interior parts of the area, mainly as a result of natural fluc- 
tuations in recharge and discharge. At the coast the transition zone was thicker because of the added effects of tidal fluctuations. The advent of ground-water development, however, imposed stresses on the system of considerably greater magnitude than the natural ones; so, the transition zone now is far greater in all dimensions than it was under natural conditions.

The first drilled well in Hawaii to penetrate to an aquifer containing a Ghyben-Herzberg lens was drilled near Ewa in 1879. Its success quickly led to the drilling of many additional wells throughout the part of southern Oahu underlain by artesian water. In Honolulu the first well was completed in 1880 , less than a year after completion of the first well near Ewa. As the development of water progressed, the formation of a thick transition zone was inevitable because of the manner in which the water was withdrawn from the lens. Heavy intermittent pumping from deep wells caused abrupt local displacement of the bottom of the lens and produced upward transfer of saline water and the formation of a wide dispersion front. Later, as heads declined and the deepest wells were abandoned because their water became too saline for economic use, a similar response was generated by shallower wells. Most of the early wells were drilled through the caprock in the artesian areas near the coast; later development also took place mainly near the coast, although some inland wells and shafts were constructed. In the Pearl Harbor area all the present major pumping stations are within 2 miles of the harbor, and in Honolulu all are within $11 / 2$ miles of the coast. The thickness of the transition zone in this band of development is virtually entirely attributable to the effects of pumping. In Honolulu it is less marked than in the Pearl Harbor area because of higher heads and a comparatively smaller quantity of water withdrawn from deep wells.

At the start of development of ground water, the maximum regional heads as reported by contemporary observers were 32 feet in the Ewa district and 43 feet in area 2 of the Honolulu district. Since then, the average heads in both areas have dropped about 15 feet. By 1900 large-scale development had already taken place, and by 1910 a quantity of water approaching the present pumpage was being withdrawn from the aquifer (see fig. 14). Early Hawaiian government records state that wells in Honolulu were discharging $15 \mathrm{mgd}$ in 1889-90, increasing to $25 \mathrm{mgd}$ during the 1890 's and to $33 \mathrm{mgd}$ by 1910 . Only about $26 \mathrm{mgd}$ is now being withdrawn in the Honolulu district in line with conservation measures introduced by the Honolulu Board of Water Supply. An early government report states that by 1900 about 


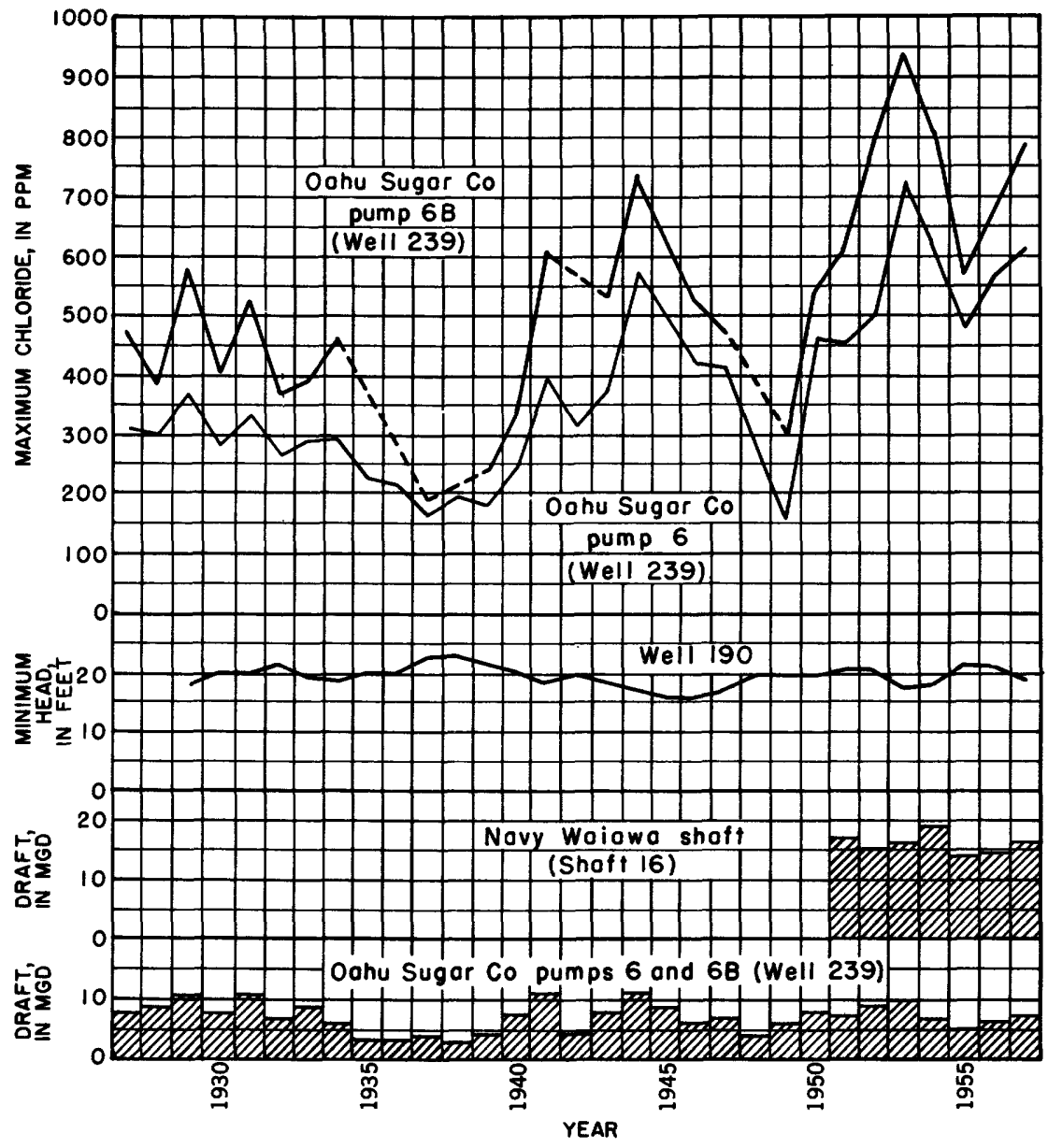

Figure 17.-Graph showing draft at Oahu Sugar Co. pumps 6 and 6-B (well 239) and the Navy Waiawa shaft (shaft 16), the head at well 190, and the chloride content of the water at Oahu Sugar Co. pumps 6 and 6-B. Compare the peak levels of chloride content at pumps 6 and 6-B during years of equal draft before and after installation of the shaft.

$245 \mathrm{mgd}$ was being pumped for sugarcane irrigation on Oahu, of which a large but unspecified part came from the Pearl Harbor area. By 1908 the three plantations in the Pearl Harbor area were operating a total of $16 \boldsymbol{T}$ wells from which $200 \mathrm{mgd}$ was being withdrawn, and 25 miscellaneous wells not operated by the plantations were producing an additional $1 \mathrm{mgd}$. In 1960 the average discharge from wells and shafts in the Pearl Harbor area was about $190 \mathrm{mgd}$. Increase in 
pumpage from the aquifer in southern Oahu to an amount comparable to that of the present took place during a relatively short period of time. Within 25 or 30 years after the first successful well was drilled, water was being pumped at a rate that, in the years since, has not changed significantly.

\section{FEFECTS OF PUMPING}

The effect of increased pumping that followed rapid ground-water development was a deterioration of the quality of water withdrawn from the coastal parts of the aquifer. In many localities seaward of main points of discharge, the transition zone grew until it occupied the entire lens. Early records show that before development began, even those wells nearest the shore produced water having a relatively low chloride content. For example, artesian wells in the Waikiki area of Honolulu contained less than $100 \mathrm{ppm}$ of chloride in 1886; today these wells are sealed because of high salinity, among other things.

In several of the heavily pumped deep irrigation wells in the Pearl Harbor area, the head at adjacent wells decreased, and the chloride content of the water pumped increased with increasing draft. This relation is shown in figure 17 by comparison of records for years of least pumping $(1935-39,1948-49,1955)$ with those for years of greatest pumping (1929, 1931, 1941, 1944, 1953). However, although the pumping from the Oahu Sugar Co. pumps 6 and 6-B (well 239) in 1953 was less than in 1929,1941 , and 1944 , the maximum chloride content was significantly greater. The increase in recent years is attributed to pumping from the Navy's Waiawa shaft (shaft 16), nearly a mile inland from the irrigation well and the only significant modifier of the previous withdrawal pattern.

Soon after heavy pumping began at the new Ewa Plantation Co. shaft (shaft 3) in about 1939, the chloride content began to increase in older pumped wells lying seaward of the shaft (fig. 18). The increase in salinity eventually caused the abandonment of Ewa Plantation Co. pumps 1 (well 268), 2 miles seaward, and 9 (well 273), 3 miles seaward. The net effect of development of the shaft has been no increase in total pumpage from the Ewa Plantation Co. wells but an improvement in the quality of total water supplies by withdrawing from an inland source instead of from deep wells tapping the transition zone near the edge of the fresh-water lens. An improvement in the quality of water from pumps 3 (well 264), 4 (well 264), and 7 (well 263) (fig. 18) is due to the effect of recharge of irrigation water of lower salinity from the shaft. 


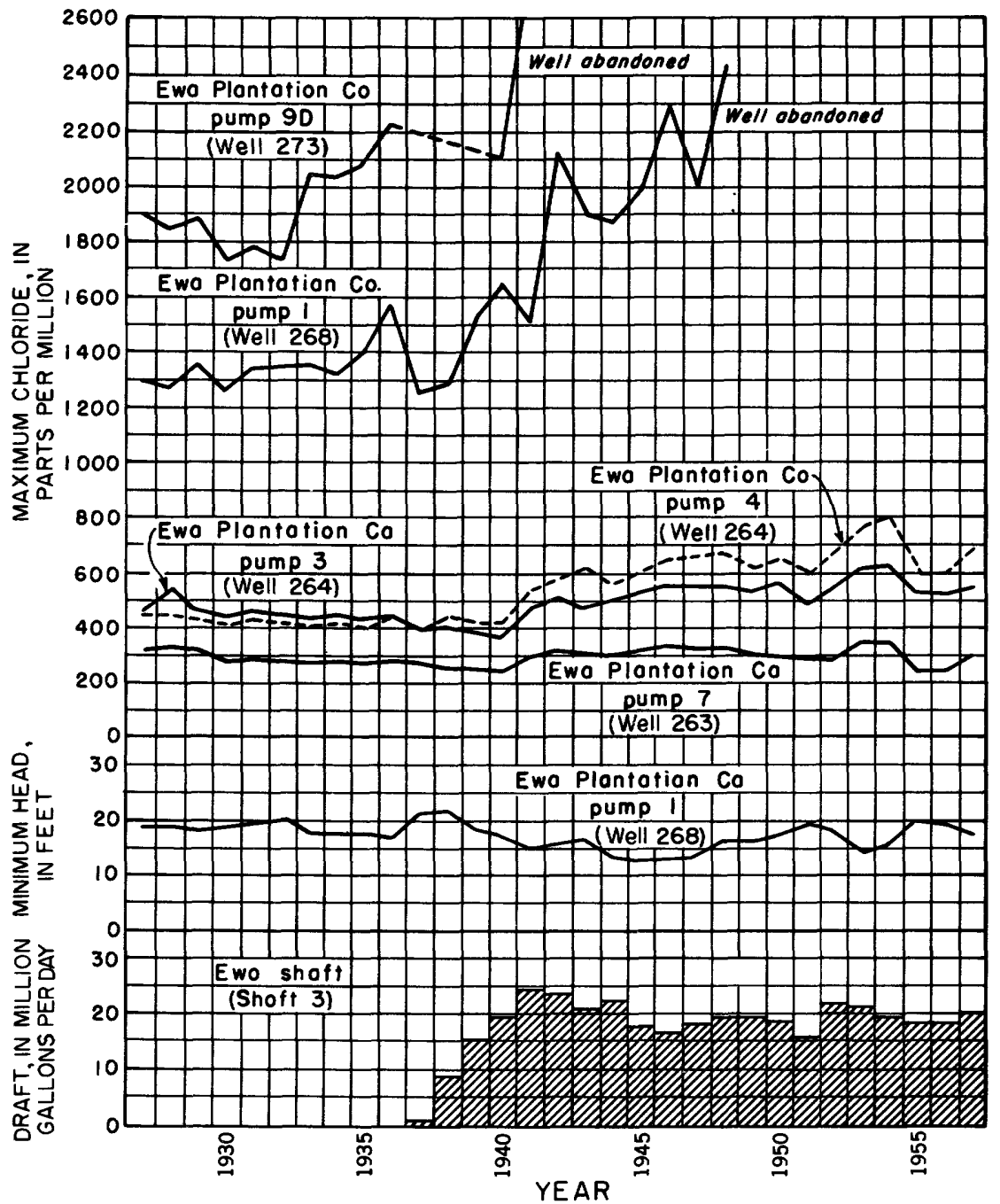

Figure 18.-Graph showing draft at Ewa shaft (shaft 3), head at Ewa Plantation Co. pump 1 (well 268) and chloride content of water at Ewa Plantation Co. pumps 1 (well 268), 3 (well 264), 4 (well 264), 7 (well 263), and 9-D (well 273). The draft at each of the pumps changes little from year to year and is therefore not shown. The combined draft from all sources was higher during the period when both pump 1 and the shaft were operating but returned to former levels when pump 1 was abandoned.

Increased pumpage has caused an increase in salinity at several wells (fig. 19). The Honolulu Plantation Co. pumps 4-E and 4-H (well 197), the Navy Aiea pump (well 187) and well 190, which lie in the eastern part of the Pearl Harbor area, were in operation before 1925. Beginning in 1936, three new wells were installed in the area- 


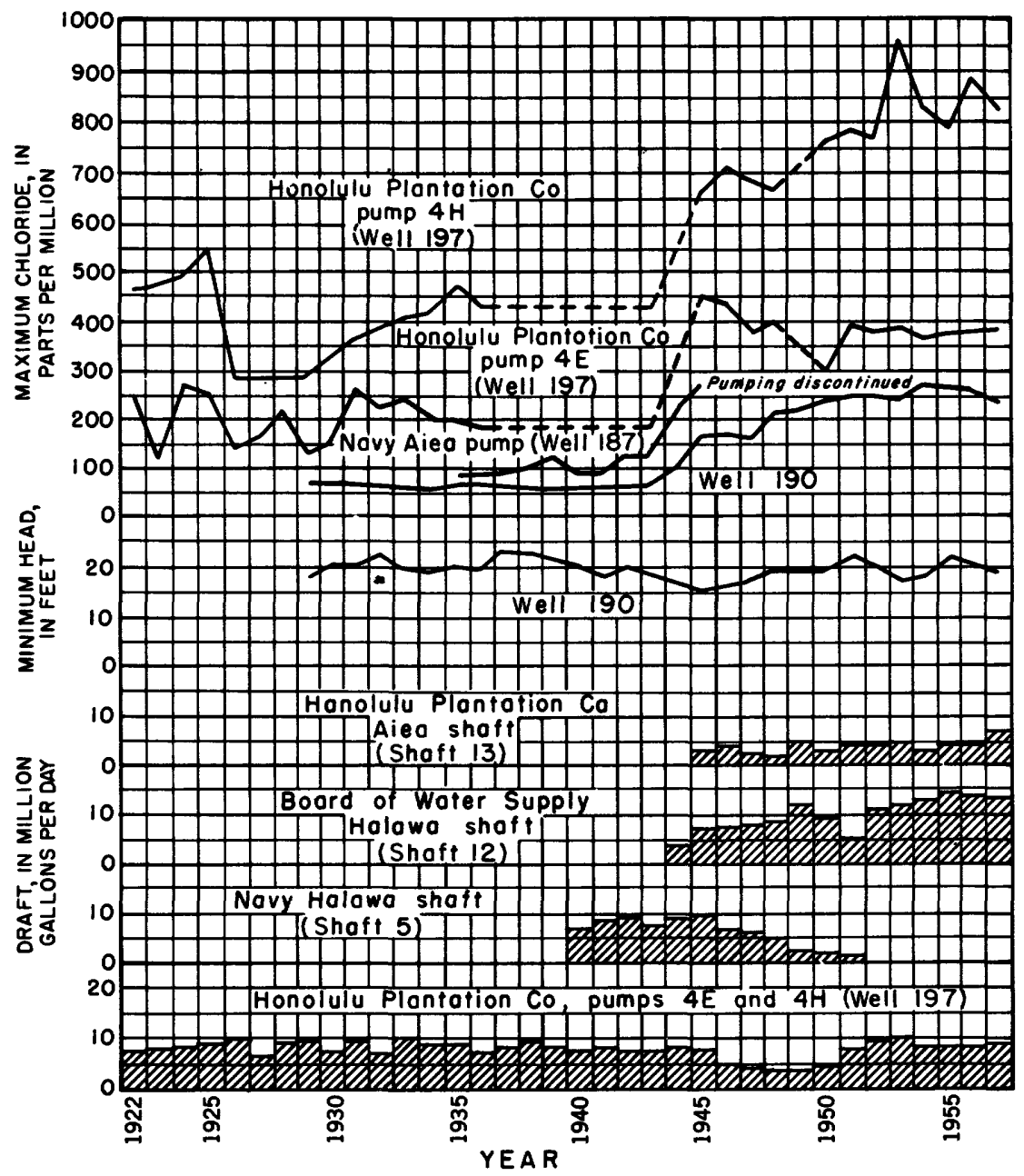

Fradre 19.-Graph showing draft at Honolulu Plantation Co. pumps 4-E and 4-H (well 197), the Navy Halawa shaft (shaft 5), the Board of Water Supply Halawa shaft (shaft 12), and the Honolulu Plantation Co. Aiea shaft (shaft 13); the head at well 190; the chloride content of water at well 190, the Navy Aiea pump (well 187), and the Honolulu Plantation Co. pumps 4-E and 4-H.

the Navy Halawa shaft (shaft 5) in 1937, the Honolulu Board of Water Supply Halawa shaft (shaft 12) in 1944, and the Honolulu Plantation Co. shaft (shaft 13) in 1945. After pumping began in the new wells, the chloride content in the older wells increased, most markedly at Honolulu Plantation 4-E and 4-H, even though the pumpage at 4-E and 4-H was generally less than in earlier years and the head, as indicated at well 190 , showed no progressive change. 
Theoretically, the intermittent operation of large-capacity pumps in a fresh-water lens could cause the rise and fall of the fresh-salt water interface and a thickening of the transition zone in a manner shown schematically in figure 8 . Through the cooperation of the Honolulu Board of Water Supply, the effect of intermittent pumping was studied at the Board's Kaimuki and Kalihi pumping stations. The Kaimuki pump (pl. 1, well 7) had been operated for many years on an off-and-on schedule designed to meet peak demands for water, and the Kalihi shaft (shaft 6) had been pumped continuously at a nearly constant rate.

A change in 1958 from intermittent to continuous operation of the Kaimuki pump was followed by a small but significant drop in the chloride content of the water (fig. 20). Throughout more than 10 years of intermittent operation of the well, the average chloride content had increased gradually but persistently. This rise appears to be unrelated either to the average draft or to the average head in area 1 but instead reflects a decrease in recharge following years of less than average rainfall (a lag of approximately 5 years is indicated). However, the trend was reversed, in that chloride content decreased when the pumping schedule was changed to a steady operation.

To meet peak demands in the municipal system during the test at the Kaimuki pump, the operation at the Board of Water Supply Kalihi shaft (shaft 6) was changed from relatively steady to intermittent pumping. Coincident with the increased on-and-off pumping at the Kalihi shaft, a sharp rise occurred in the chloride content of the water in well 153, which lies seaward of the shaft (fig. 21). The chloride content in well 153 changed little over a period of many years until 1958, when it increased sharply when on-and-off pumping began at Kalihi shaft. The rise is attributed to a thickening of the transition zone caused by the intermittent pumping at the shaft.

Pumping in the Pearl Harbor area has an additional effect on the salinity of the basal water because of the use of irrigation water drawn from wells penetrating into the transition zone. Where this water is applied to sugarcane fields overlying the basal-water table, a large part of it moves down to the water table and adds water of relatively high salinity to the top of the fresh-water lens. This contamination is offset in large measure by natural recharge from high-rainfall areas and by the deep infiltration of fresh irrigation water imported from windward Oahu in the Waiahole Ditch Tunnel. More serious effects on the lens by saline irrigation water could result from a reduction in the fresh-water recharge or a large increase in pumpage from the lens. 

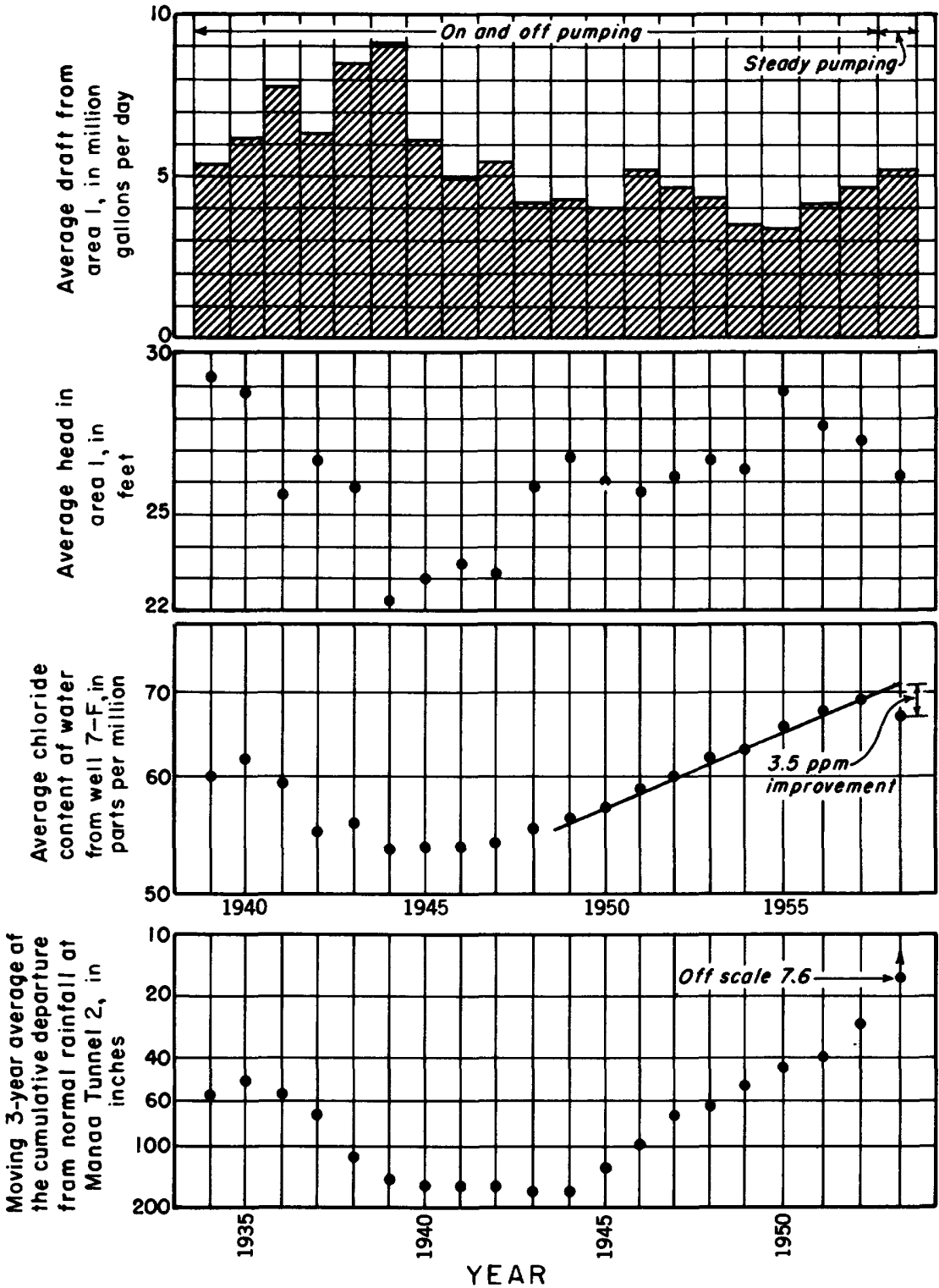

FIGURE 20.-Graph showing decrease in chloride content of water in well 7-F at the Honolulu Board of Water Supply Kaimuki pump after a change from intermittent to continuous pumping. Shown also are the average dally draft and the average head in area 1 in the Honolulu area and the 3-year moving average of the cumulative departure from normal rainfall at Manoa tunnel 2. There appears to be a 5-year lag between the amount of rainfall and an improvement or deterioration in water quality; so, the time scale is shifted in the bottom graph. 


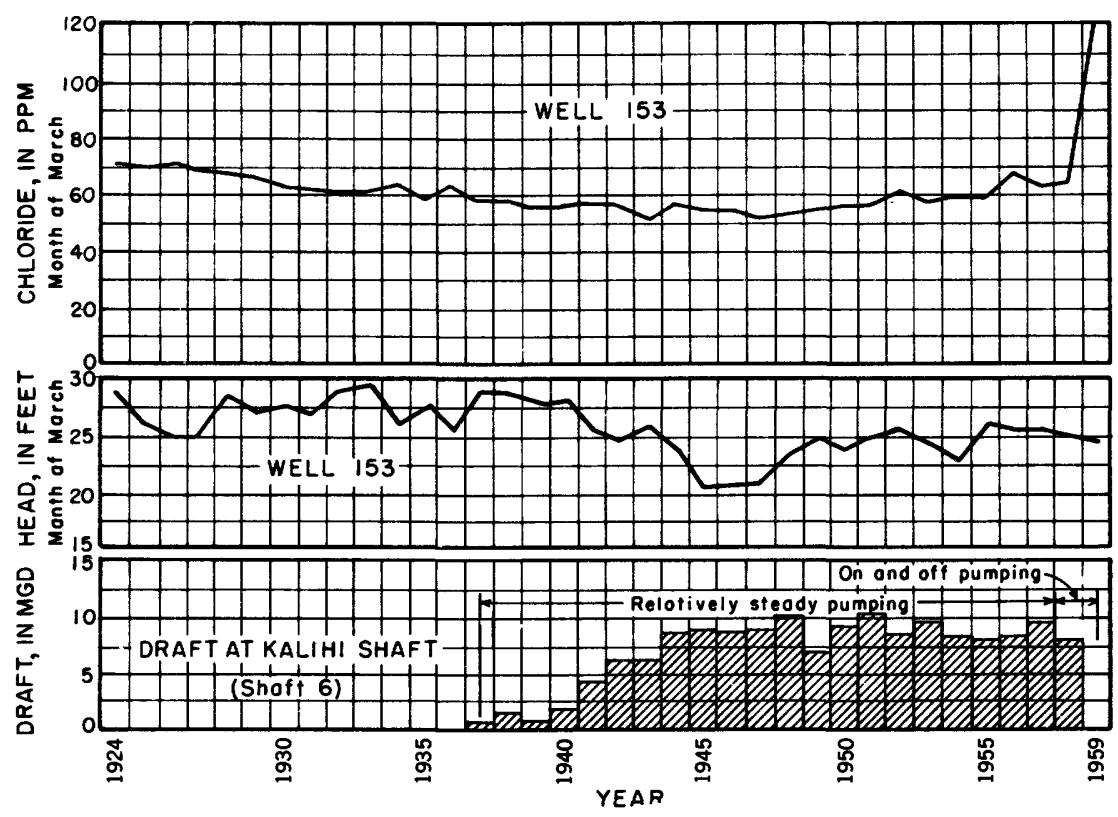

Figdrm 21.-Graph of chloride content and heal at well 153 for the years 1924-58, showing rapid rise in chloride associated with on-and-off operation of the Kalihi shaft (shaft 6 ).

The water from many springs and from most of the old wells in the Pearl Harbor area is now more saline than it was 50 years ago. This increase is shown by the change in position of the $200-\mathrm{ppm}$ and 1,000-ppm isochlors (fig. 22). Although the diagram shows only the change from 1910 to 1950 , most of this change occurred before 1925. The inland movement of the zone of transition shown in figure 22 would involve also an upward movement of saline water into the zone once occupied by fresh water.

In the Ewa area a seaward movement of the 200-ppm isochlor has occurred since 1910. Beginning about 1913, about $30 \mathrm{mgd}$ of water containing less than $15 \mathrm{ppm}$ of chloride has been imported through the Waiahole tunnel system and used for irrigation of sugarcane in the western part of the Pearl Harbor area. Deep seepage of a large part of this water recharges the basal water body and has a freshening effect on the ground water.

\section{TRANSITION ZONE AT THE PEARL HARBOR SPRINGS}

In an unconfined Ghyben-Herzberg lens on which there are no external stresses and in which recharge and discharge are constant, discharge of fresh uncontaminated water takes place along the shore in a narrow zone at the edge of the lens. However, if a transition zone 


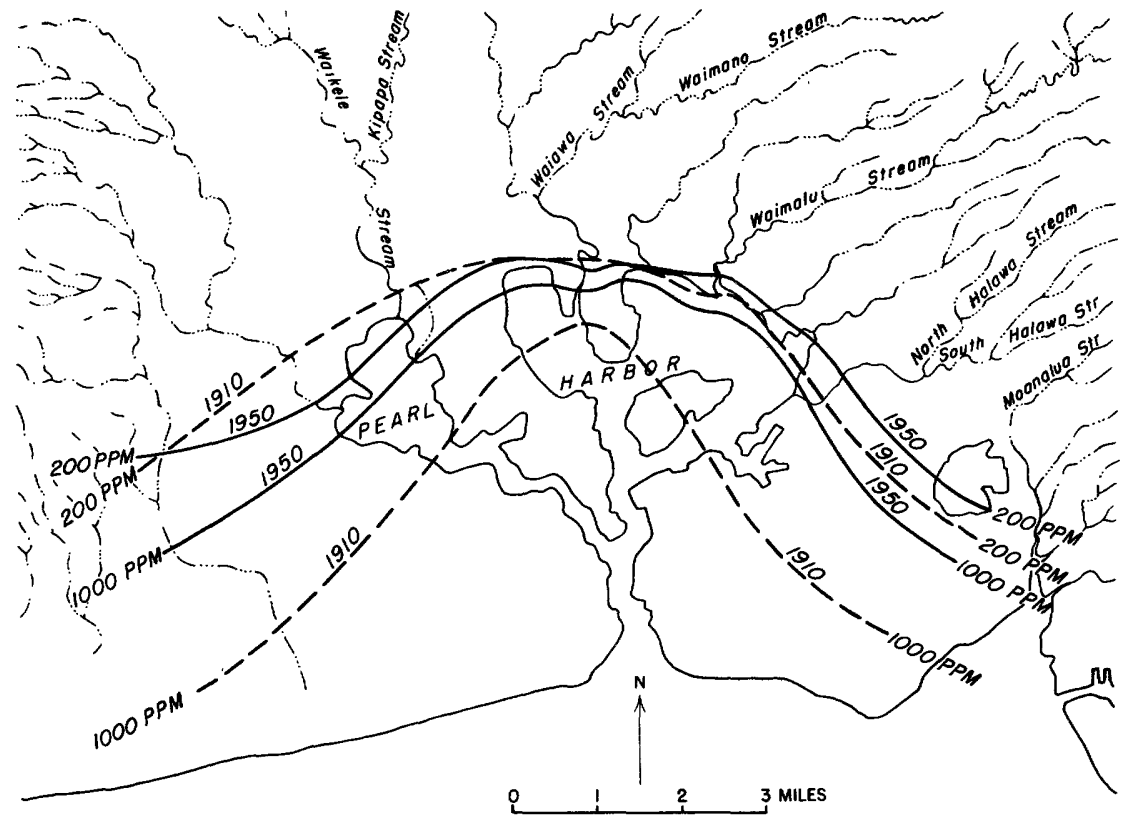

F'IGdRe 22.- Map showing the approximate change in position of the 200- and 1,000-ppm isochlors in the Pearl Harbor area between 1910 and 1950.

exists, the discharge includes some saline water because the flow toward the sea extends through the transition zone. The natural discharge from the confined aquifers of southern Oahu includes water from the transition zone and occurs over a wide zone as leakage into the caprock or as springs welling up through breaks in the caprock. The nature of the caprock prevents the determination of the quality of the water passing into it, but the spring flow is a sensitive indicator of the quality of the water in the upper part of the transition zone because of the considerable width of the zone in which the discharge occurs.

The pattern of flow in a Ghyben-Herzberg lens is such that the freshest flow discharges at the inland edge of the discharge zone and the saline flow discharges toward the seaward edge. In a discharge zone of sufficient width, the entire transition zone would be represented by the water appearing at the surface along a line starting at the inland margin of the spring area. Around the shore of Pearl Harbor, however, discharge at the ground surface includes only water in the upper part of the transition zone; the remainder presumably discharges at submarine springs in the harbor or as leakage into the coralline part of the caprock (fig. 23).

A sampling program at the Pearl Harbor springs during the 3year period of 1957-59 provided evidence of the relationship just 


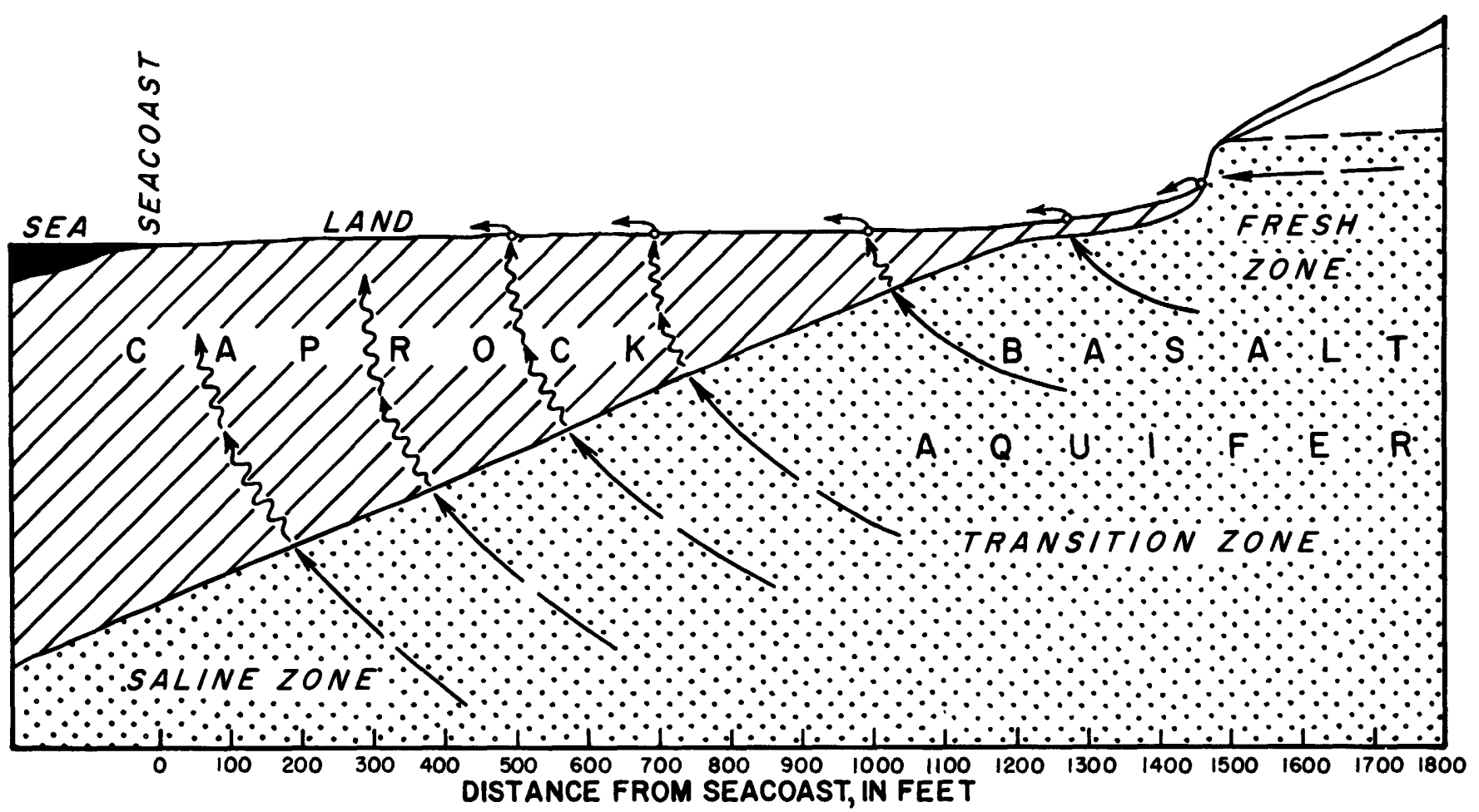

FiguRm 23.-Diagram showing generalized pattern of discharge at springs in the Pearl Harbor area. The discharging water becomes increasingly saline toward the shore, as it is fed by flow originating progressively deeper in the transition zone. 
described. Samples collected at selected points of discharge (orifices) in the spring areas ranged in chloride content from about $90 \mathrm{ppm}$ at the most inland margins to about $3,200 \mathrm{ppm}$ at an orifice close by the shore of the harbor. Tidal fluctuations have no measureable effect on the chloride content of the springs, as the fresh-water lens is very thick and is separated from the ocean by the caprock.

The distribution of chloride at the Kalauao, Waimano and Waiawa Springs during the summer of 1957 is shown in figures 24-26. Isochlors were drawn on the basis of samples from separate spring orifices and shallow artesian wells. The bottoms of the wells are near the top of the aquifer, and the wells are comparable to the spring orifices as indicators of the salinity of the water.

At Kalauao the water is least saline (about $90 \mathrm{ppm}$ of chloride) at the inner margin of the spring area and progressively increases in salinity to about $800 \mathrm{ppm}$ of chloride at the shore over a distance of 1,500 feet. In the discussion of geochemistry and temperature (p. 72), it is shown that the orifices at the most inland margins of spring areas are likely to be affected by return irrigation water, which explains the variation in chloride content between 93 and $140 \mathrm{ppm}$ along the inland margin. The orifice from which water having 93 $\mathrm{ppm}$ of chloride flows is very large in contrast to those from which water having $140 \mathrm{ppm}$ of chloride flows, and it probably discharges more water from depths below those affected by irrigation recharge. A similar relationship is found at other springs also.

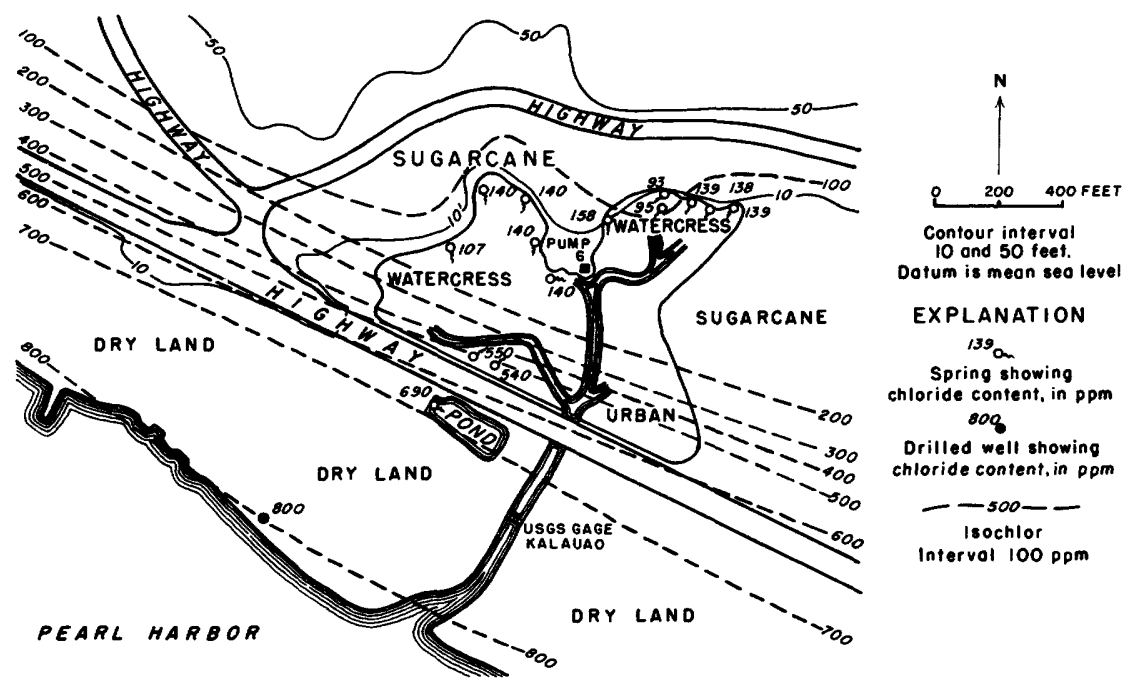

FigdRe 24.-Distribution of chloride content, in parts per million, of ground water in the Kalauao Springs area in August 1957. 


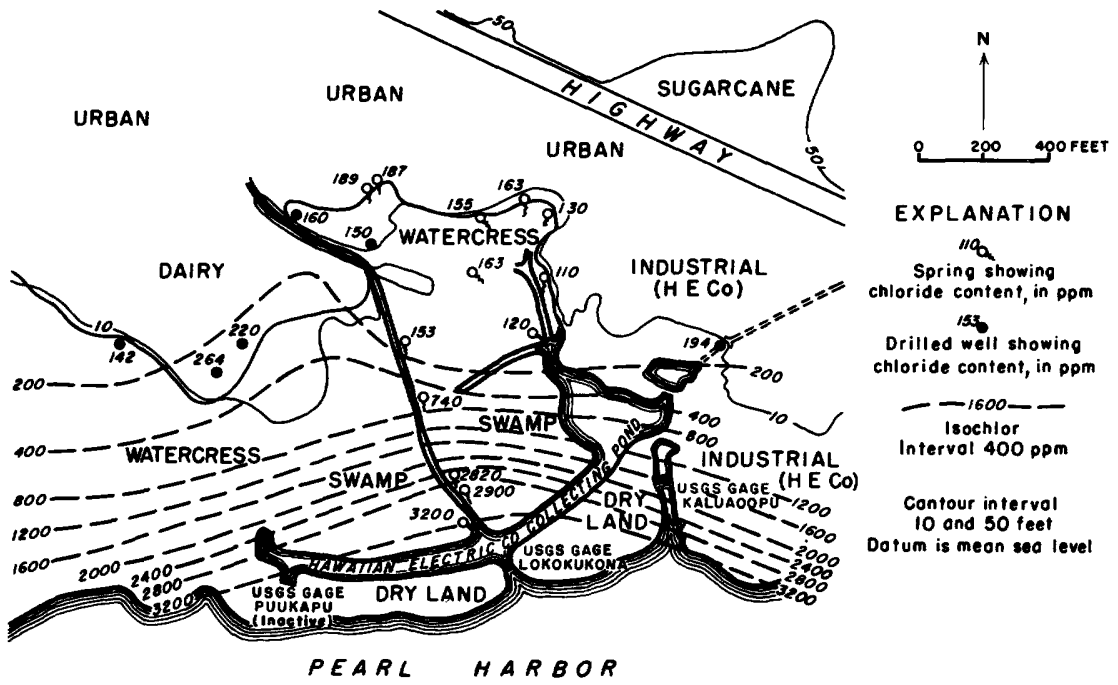

Figdre 25.-Distribution of the chloride content, in parts per million, of ground water in the Waimano Springs area in August 1957.

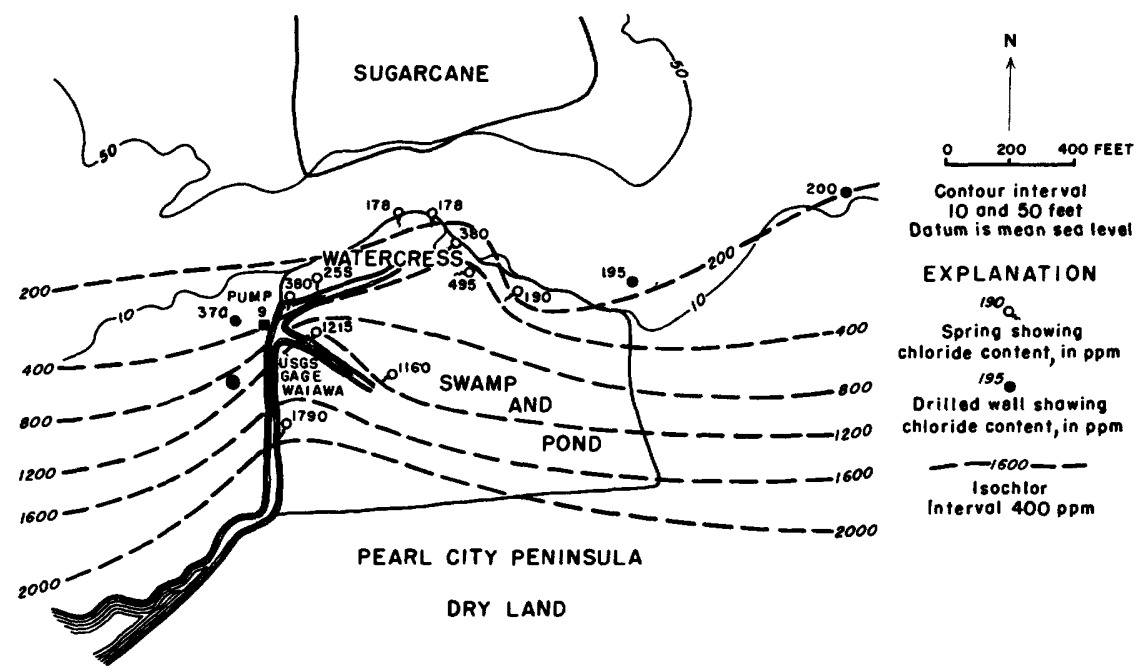

F'igure 26.-Distribution of the chloride content, in parts per million, of ground water in the Waiawa Springs area in August 1957.

In the Waimano Springs area the freshest water contains $110 \mathrm{ppm}$ of chloride. The most saline water contains $3,200 \mathrm{ppm}$ of chloride and comes from the most seaward orifice, 1,200 feet from the inland margin. Here the chloride gradient is much steeper than at Kalauao Springs as a result of the more intensive development of ground water in the vicinity, particularly at the Hawaiian Electric Co. power-generating plant. In addition to using spring water for industrial pur- 
poses, the company also pumps about $10 \mathrm{mgd}$ from a short tunnel in which wells are drilled. If the water discharging from Waiau Springs, which is a short distance up the hydraulic gradient from Waimano Springs, is included, then about $50 \mathrm{mgd}$ discharges from an area about half a mile long in a northerly direction and 1,500 feet wide in a direction parallel with the shore.

At Waiawa Springs (fig. 26) the freshest water at the inland orifices contains somewhat less than $200 \mathrm{ppm}$ of chloride, and the most saline near the coast contains almost $2,000 \mathrm{ppm}$ of chloride. The distance along the gradient between these two points is about 600 feet. As at Waimano, much water discharges within a relatively small area, and, in addition, large pumping stations are located about 2 miles inland up the hydraulic gradient from the springs.

The isochlor maps of the spring areas show a wide variation in quality of the water flowing from the springs, which must be considered in using the springs as sources of water. It is interesting to assess the quality of the composite flow of each spring group where it is measured at gaging stations. The gage at each spring is placed where the collected spring water flows in a single channel. At Kalauao Springs the composite flow past the gaging station includes water discharging in the area lying between approximately the $100-\mathrm{ppm}$ and $700-\mathrm{ppm}$ isochlors. The average chloride content at the gage is 155 ppm, which suggests that only a small amount of the most saline water is mixing with the fresh water and therefore that a large supply of fresh water is available. At Waiau Springs the average chloride content of the composite flow is $180 \mathrm{ppm}$. In this area all the water has low salinity, as none of the orifices discharges water containing more than $250 \mathrm{ppm}$ of chloride.

An accurate evaluation of the average chloride content of the water at Waimano is not possible because no single gaging station measures the total mixed flow of the springs. It is evident from figure 25, however, that much of the area contains water of poor quality, even though the largest flows originate from orifices in which the chloride content is less than $200 \mathrm{ppm}$. At Waiawa the composite flow at the gaging station contains an average of $800 \mathrm{ppm}$ of chloride. The orifices discharging water of least salinity are restricted to the most inland part of the area, and although much good quality water discharges there, great care would have to be taken to prevent its mixture with the saline component. The water of Waikele Springs is uniformly good throughout the determinable spring area. It has a chloride content ranging from 70 to $175 \mathrm{ppm}$. This spring area is not as well defined as the others, and measurement of the discharge is 
complicated by the fact that Waikele Stream is the main collecting channel for the springs. In addition to carrying spring water, the Waikele Stream serves as a wasteway for water from the Oahu Sugar Company mill, and during wet periods it also carries surface runoff.

\section{BEHA VIOR OF THE TRANSITION ZONE IN RESPONSE TO CHANGES IN THE POSITION OF THE LENS}

Although the chloride content of water at a specific orifice in a spring area may vary with time, the relation of the chloride content among all the orifices in a spring area at any particular time is generally the same; that is, the relation between the fresher and more saline water, as shown in figures 24-26, holds true even though the isochlors may change in value. The least variations in chloride concentrations are found at the most inland orifices, where water from the upper part of the lens is discharged. This condition is to be expected, because the uppermost flow is least affected by short-term fluctuations in the position of the transition zone. The chloride concentrations at the more saline orifices, which are fed by flow from deeper in the lens, are considerably more variable because they are quickly affected by the movement of the transition zone in response to stresses imposed on the lens. As this movement is the result of fluctuations in head, the quality of the water from the deeper flow can be correlated with the head.

Where discharge is natural, the relation between chloride concentration and head is a direct one. Natural discharge is best seen at the Pearl Harbor springs, but flowing artesian wells simulate springs; so, spring orifices and flowing wells both have the direct relation. Where wells and shafts are heavily pumped, however, the chloride and head usually show an inverse relationship, because when heads are low and pumping is greatest, water from the transition zone is drawn into the well. This inverse relation is evident at some heavily pumped wells in the Honolulu and Pearl Harbor areas.

A typical direct chloride-head relation may be seen in the Waimano and Waiawa Springs areas, where high-chloride water from the transition zone discharges from orifices and free-flowing artesian wells. Well 201, an artesian well lying between these spring areas and having a large free flow, is especially instructive because of the long period of record available for it and the sensitivity of response of the quality of its water to changes in head. The variation of chloride content at Waiawa Springs and well 201 with head at well 201 over the 3-year period 1957-59 are shown in figures 27 and 28 . The spring orifices used in figure 27 were chosen because they have large flows and are likely to be free of water recharging from irrigated fields. Head readings at well 201 were taken at the time of sampling. The diagram 


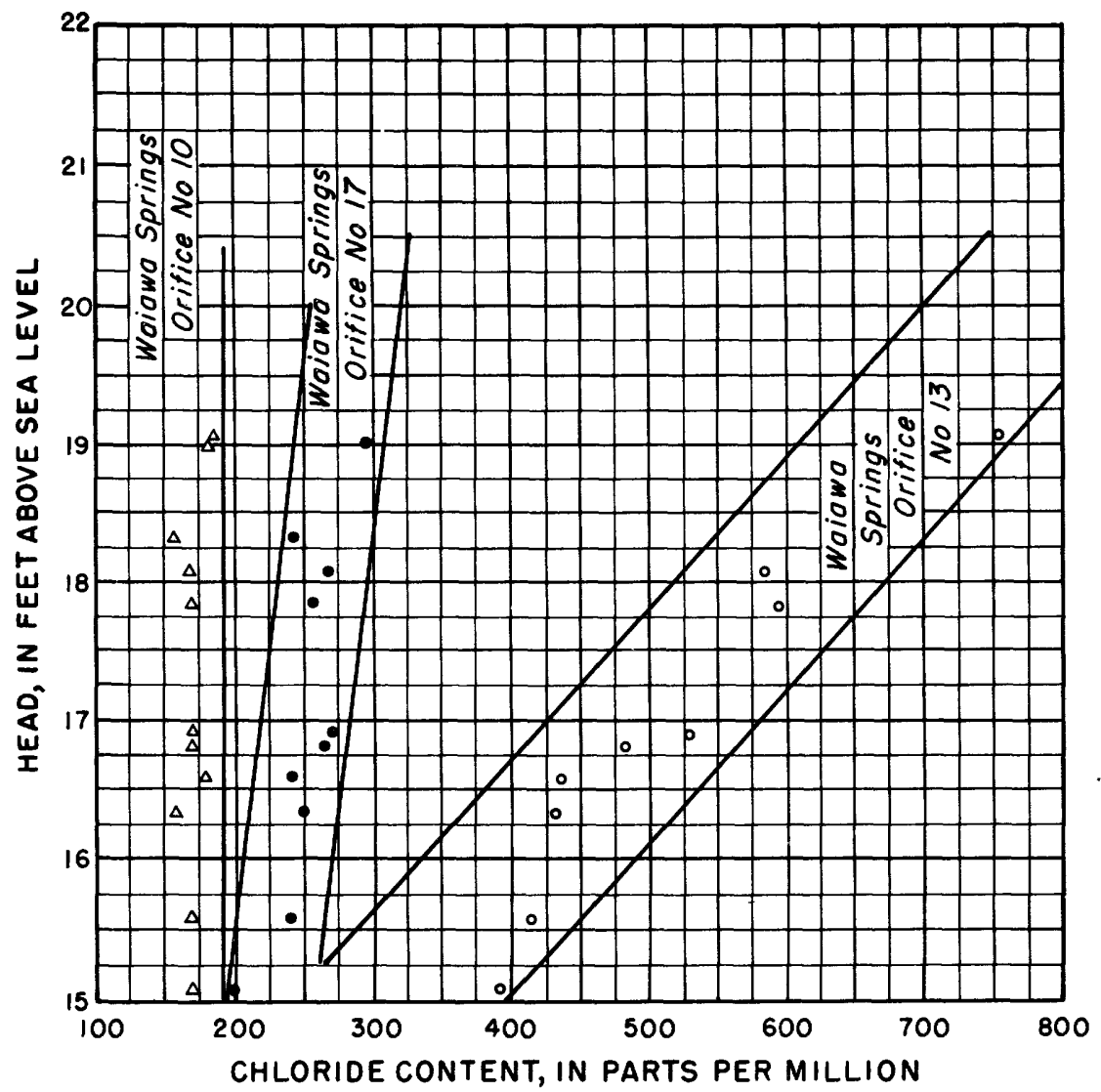

FIGURE 27.-Relation between chloride content of water at Waiawa Springs and head at well 201 during the period 1957-59.

shows that water from the well and from the most saline orifice (No. 13) increases greatly in chloride content with an increase in head and that the chloride content of water from orifice 10, which discharges water from the upper part of the lens, is virtually constant. The chloride at orifice 17, which is seaward of orifice 10 and somewhat more saline, shows a small but definite response to change in head.

A similar relation holds at Waimano Springs. The chloride content at the spring rises roughly $300 \mathrm{ppm}$ per foot of increase in head at well 193 at orifice 27 and $200 \mathrm{ppm}$ per foot at orifice 25 (fig. 29). The freshest water from the inland margin of these springs, which is not shown on the plot, shows no measurable variation with head, as its flow originates in the upper part of the lens and is not influenced by short-term effects. 


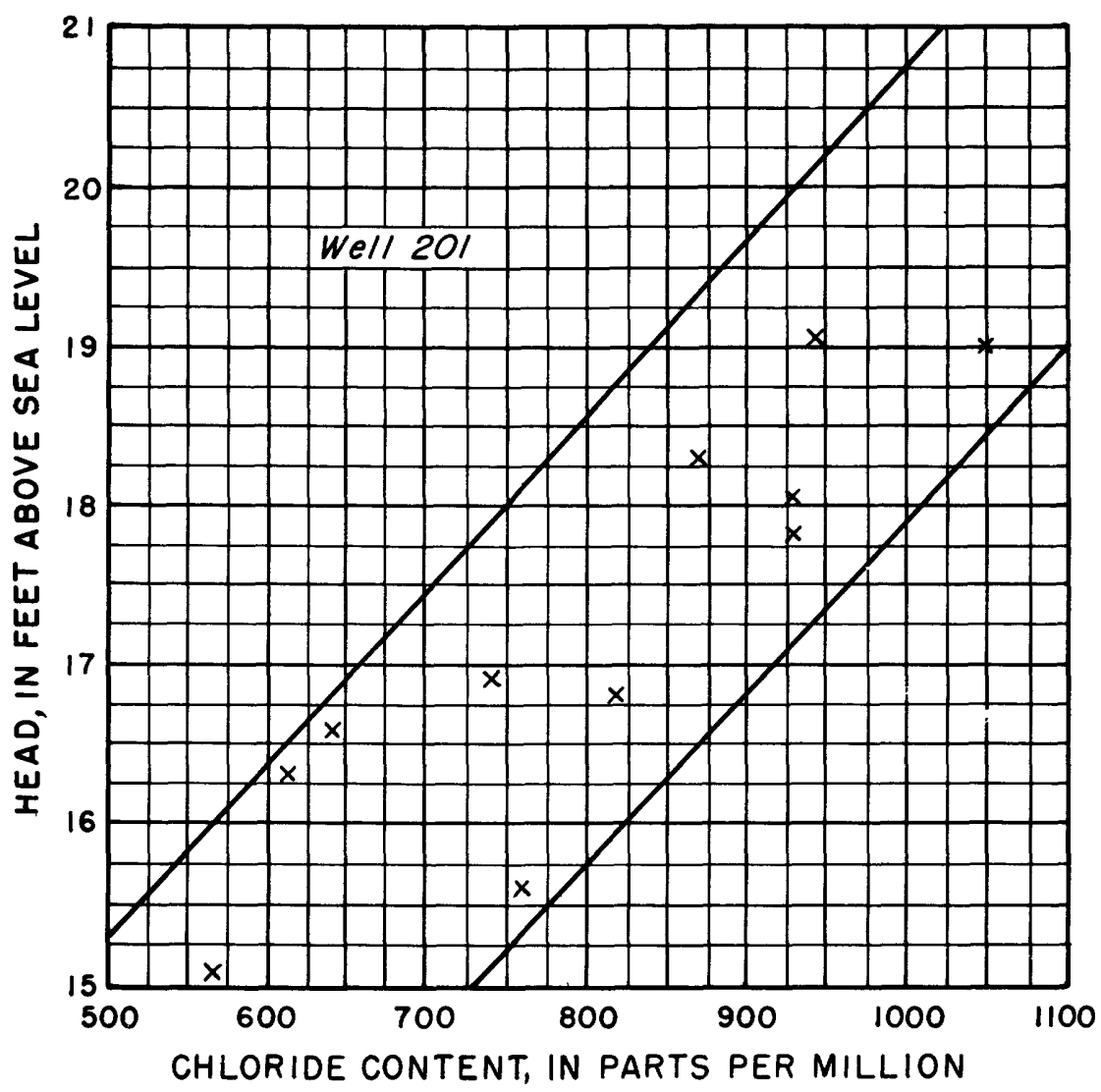

Frgurm 28.- Relation between chloride content of water and head at well 201 during the period 1957-59.

The conclusion that the salinity of water discharging from the transition zone in a particular area is reversible-decreasing during contraction of the lens and increasing during expansion-is applicable only when the fluctuations of the lens occur about a long-term mean position. Thus, seasonal deficiencies in recharge lead to a decrease in chloride content of naturally discharging water, and high recharge produces water having a higher chloride content. The flow pattern from which these changes result are schematically shown in figures $30-32$. Figure 30 illustrates the lens at a time when neither expansion nor contraction is taking place. In figure 31 the lens thickens as a result of high recharge. The bottom of the lens is pushed downward, and a part of the aquifer that had contained saline water then becomes intruded by fresher water. Some of the saline water remaining behind, entrapped in voids and fractures and as surface films on the rocks, mixes with the encroaching fresh water. 


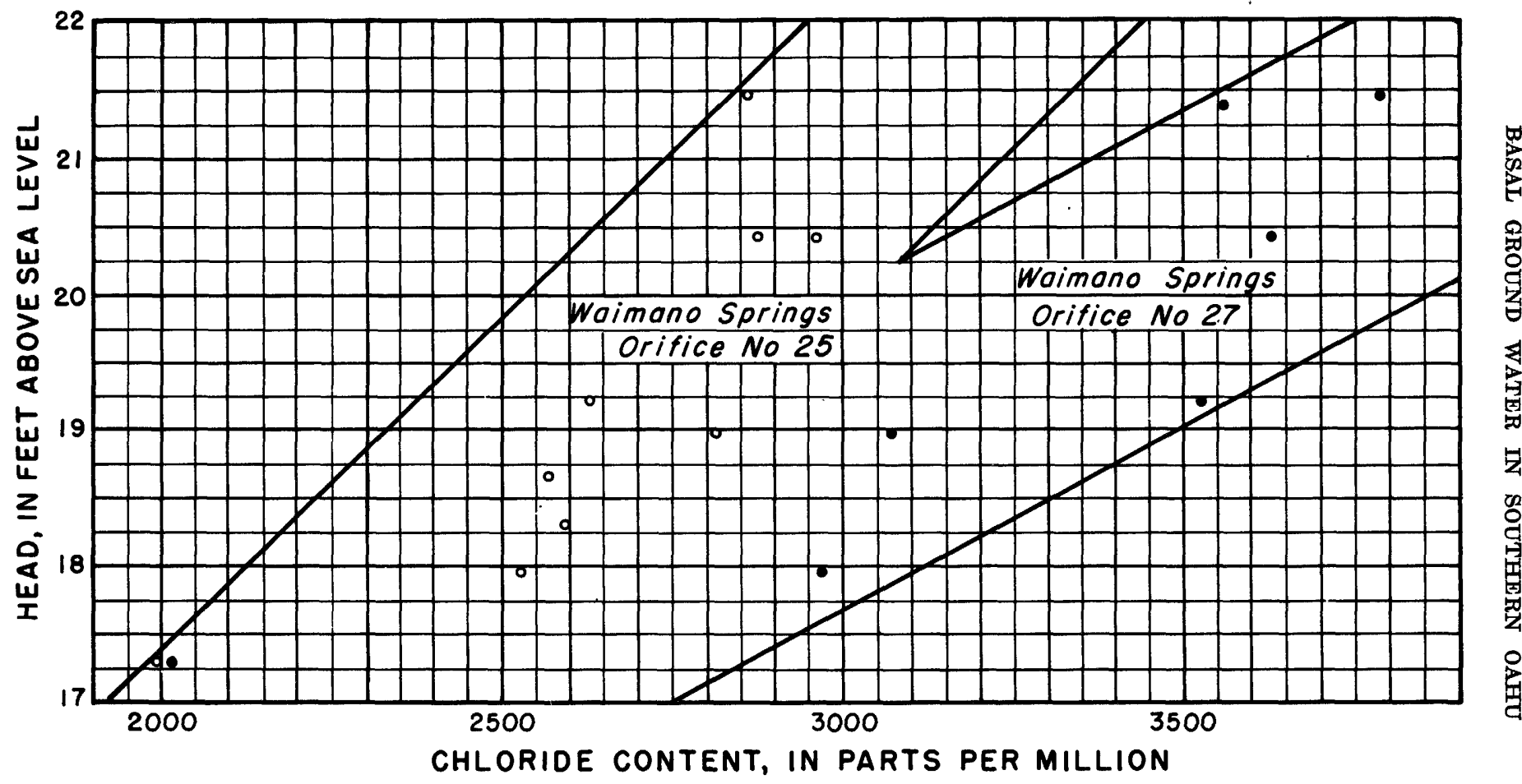

Figurn 29.-Relation between chloride content and head in the Waimano Springs area. 


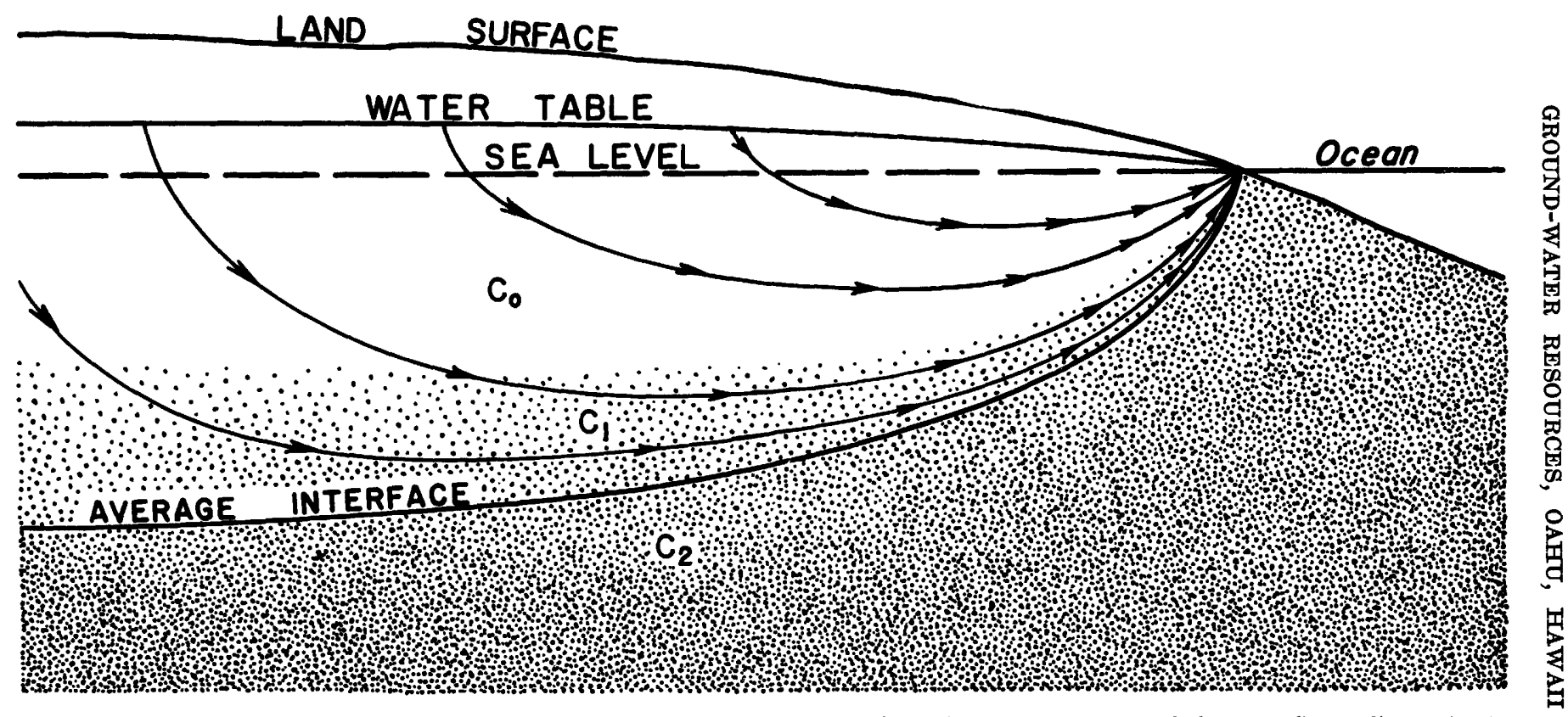

FraURw 30.-Diagram showing generalized flow lines in a Ghyben-Herzberg lens. $C_{0}$ is the fresh-water core of the lens; $C_{1}$ is saline water in the transition zone that is affected by the flow of water through the lens; and $C_{2}$ is saline water lying below the circulation pattern in the lens. 


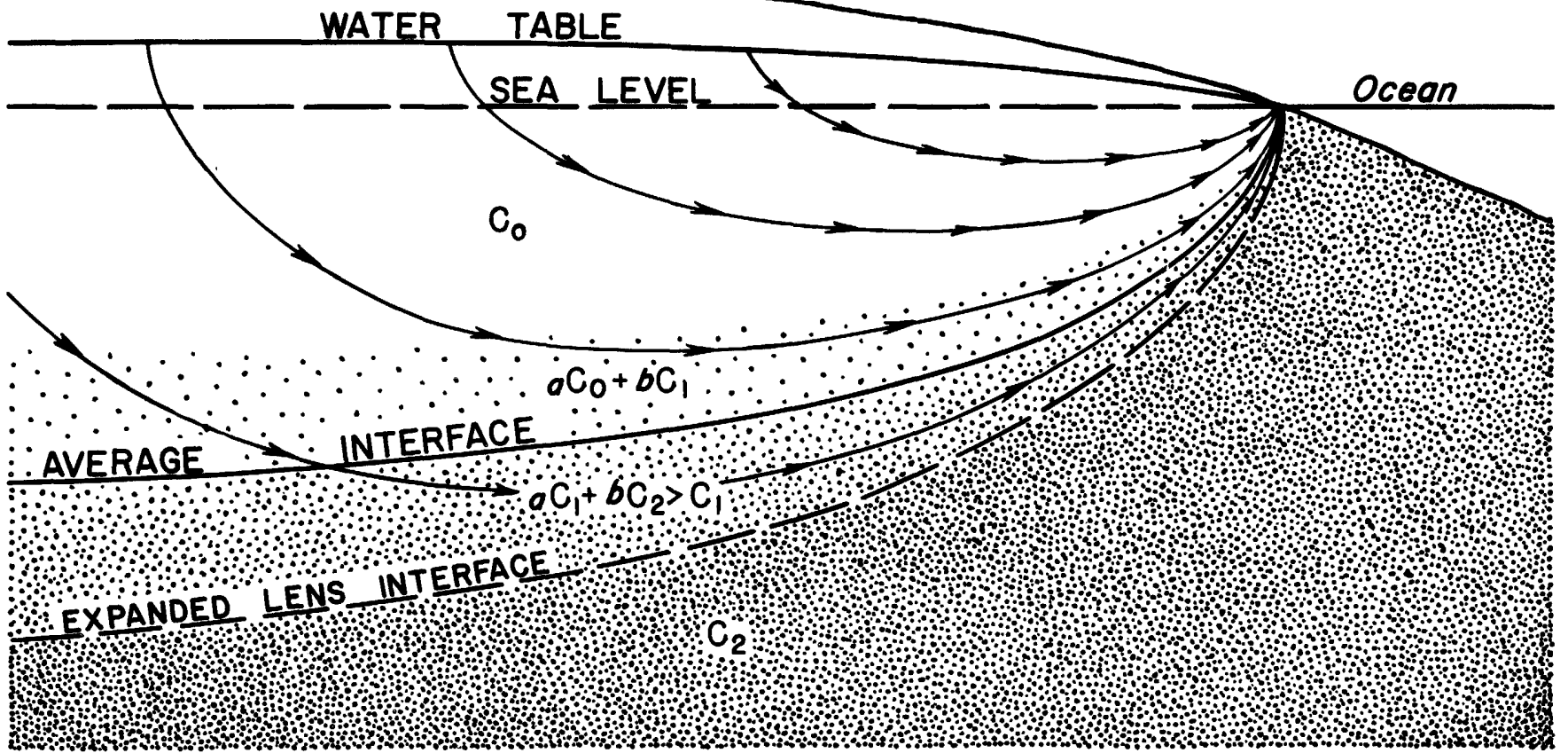

Figure 31.-Diagram showing the expansion of the Ghyben-Herzberg lens during high recharge during which water from the fresh-water core, $C_{0}$, invades the transition zone water of $C_{1}$ in figure 30 , and water from $C_{1}$ invades the more saline water of $C_{2}$. Downward movement of the zone of circulation accompanying the expansion of the lens causes an increase in seaward movement of saline water. 


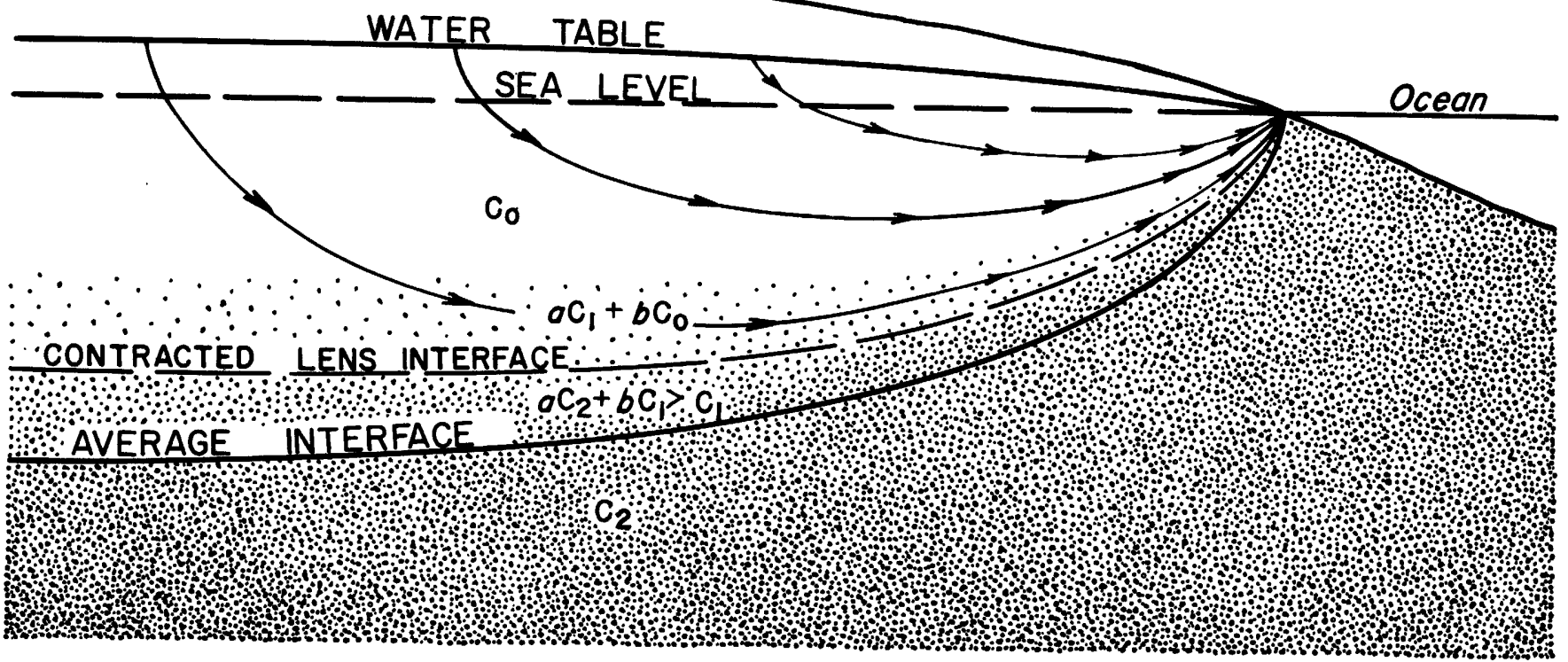

Figorm 32.-Diagram showing the contraction of the Ghyben-Herzberg lens during reduced recharge. Upward movement of the zone of circulation that accompanies the contraction of the lens results in a reduction of saline water moving toward the shore. 
The zone of circulation deepens and the mixture of fresher water and remnant saline water moves toward the shore, thus increasing the chloride content at the orifices which formerly discharged only the fresher water. High recharge over a sufficient time would rinse out the mixture, and the salinity at the orifice would then decrease. During a period of reduced recharge, the lens behaves as shown in figure 32. The lower surface moves upward, and saline water encroaches where fresher water had been previously. Some of the fresher water remains behind to mix with the saline water, but the density within the intruded zone is greater than that during the comparable downward invasion of the fresher water; the flows are therefore compressed, thus driving fresher water to the orifices.

\section{UTIIIZATION OF BASAL WATER}

Since 1919 the pumpage from wells in the Pearl Harbor area has ranged from 140 to $190 \mathrm{mgd}$ and averaged about $160 \mathrm{mgd}$ (fig. 14). The zone of transition moved inland and thickened, and the freshwater lens shrank during this period of heavy withdrawal. The amount of fresh water now stored in the reservoir is appreciably less than before any wells were drilled. But the continued heavy pümping for several decades, resulting in only minor fluctuations in the shape and size of the fresh-water lens, is a strong indication that under the prevailing conditions of development and use the draft does not exceed the sustained yield of the system. On the other hand, the installation of new large-capacity wells has not resulted in an appreciable increase in the overall draft in the area. The basal water system in the Pearl Harbor area, therefore, seems to be virtually in equilibrium.

The average discharge of water of low salinity from the Pearl Harbor springs is about $87 \mathrm{mgd}$. About $13 \mathrm{mgd}$ of this is pumped to sugarcane fields, and the remaining $74 \mathrm{mgd}$ discharges into the sea after flowing through watercress or other wetland crops or through heat exchangers at the Waiau power station of the Hawaiian Electric Co. In addition to the water from the springs, about $15 \mathrm{mgd}$ is discharged by nearshore wells into the harbor through wetland crops, and about $10 \mathrm{mgd}$ is discharged through the power station. Thus the discharge of basal water of good quality by springs and flowing wells averages about $110 \mathrm{mgd}$, and the total from all wells and springs is approximately $270 \mathrm{mgd}$.

However, during periods of maximum demand and pumping for sugarcane irrigation, the flow into the harbor is materially lower. During the summers of 1953 and 1954, for example, when pumping for irrigation from wells and springs averaged $260 \mathrm{mgd}$, the flow from 
the springs into the harbor was $31 \mathrm{mgd}$, the flow from wells at the powerplant was $8 \mathrm{mgd}$, and the flow from wells watering wetland crops was about $5 \mathrm{mgd}-\mathrm{a}$ total of $44 \mathrm{mgd}$ from springs and flowing wells.

Of the total average pumpage of about $160 \mathrm{mgd}$ from basal ground water, about $130 \mathrm{mgd}$ is used for the irrigation of sugarcane in the Pearl Harbor area. In addition, about $13 \mathrm{mgd}$ is pumped from the Pearl Harbor springs, and about $30 \mathrm{mgd}$ of high-level water is diverted from windward Oahu through the Waiahole Ditch for sugarcane irrigation. About one-fourth of the total irrigation water, nearly $180 \mathrm{mgd}$, is used on fields lying on the caprock, but the remainder goes to the higher fields where much of the water in excess of the needs of the sugarcane moves into the basal ground-water reservoir.

Studies in Maui by the Hawaiian Sugar Planters' Association indicate that the consumptive use of water by sugarcane is about the same as the evaporation from a U.S. Weather Bureau class A evaporation pan in the same area. On this basis, the calculated consumptive use of sugarcane in the Pearl Harbor area is about one-third of the water pumped or diverted to the fields. If all the remaining twothirds of the water moves downward to the water table by deep seepage, the average recharge to the basal aquifer (underlying about threefourths of the area irrigated) from water applied to the fields in the Pearl Harbor area amounts to about $90 \mathrm{mgd}$. Surface runoff from the irrigated area is small. The return of irrigation water to the basal water table has been important in the replenishment of the basal system during the long period of heavy pumping in the Pearl Harbor area.

\section{QUANTITY OF WATHR AVATLABLE}

The most striking aspect of the graph of annual pumpage from areas 6 and 11 in the Pearl Harbor area (fig. 14) is the indicated lack of a large change since the middle 1920's. During this period, the pumpage ranged from about 140 to $190 \mathrm{mgd}$ and averaged somewhat more than $160 \mathrm{mgd}$. Apparently, the draft from new wells was offset by reduced draft at other wells, and the addition of new wells throughout this period has not resulted in a sustained increase in draft.

The unused flow of ground water from the Pearl Harbor area is from the Pearl Harbor springs, which over the 18-year period starting in 1940 averaged about $70 \mathrm{mgd}$ (based on head-discharge relationships). The $70 \mathrm{mgd}$ includes spring water that is used only for cooling. If the flow of the springs could be controlled so that water discharges only when it is needed, the whole $70 \mathrm{mgd}$ could be developed. The flow, however, is uncontrolled and is greatest in the winter when the need is least and least in the summer when the need is greatest. 
Because the flow cannot be controlled and because storage of the water is not feasible, development of the unused flow should probably be based on the low flow of the springs. The lowest flow of recent years was during the drought of 1953 and 1954. At this time the base flows of the springs were as follows: Waikele Springs, $6 \mathrm{mgd}$; Waiawa Springs, $7 \mathrm{mgd}$; Waiau-Waimano Springs, $10 \mathrm{mgd}$ (plus $8 \mathrm{mgd}$ from wells); and Kalauao Springs, $8 \mathrm{mgd}$. In addition, the flow to the harbor from wells watering wetland crops in the lowland was about $5 \mathrm{mgd}$.

The ground water in areas 3 and 4 is tributary to that in area 6 and to the Pearl Harbor springs and, therefore, cannot be considered as a separate source for additional development. Areas 1 and 2, however, are separate andi might contain water for additional development. Because the amount of natural discharge from areas 1 and 2 is unknown, the amount of additional water that can be developed in them cannot be estimated. The best way to determine the additional water is by gradually increasing the pumpage and observing the effects on water levels and salinity of the water in the areas. Substantial additional supplies might be available from areas 1 and 2 .

\section{METHODS OF DEVELOPMENT}

Under the conditions of equilibrium all the additional water that is to be had in the Pearl Harbor area is that flowing from the Pearl Harbor Springs and nearshore wells into Pearl Harbor. The water discharging in the swamps below the springs or directly from the aquifer into the harbor probably is too saline for domestic or irrigation use. Development of the additional water must be by pumping directly from the springs or by controlling the flow of the springs by pumping from wells. In the past, pumping from wells has lowered the head sufficiently to reduce the spring flow by an amount equivalent to thwi pumped. This process could be continued until the heads and spring flow drop to very low levels, if it were not for the location of many of the pumping stations. Lowering the head in the future, as in the past, will tend to increase the salinity of these stations. The most direct approach to the development of the additional water is to collect and use it directly from the springs. The fresh spring water would probably require some sanitary treatment for municipal use. It could, however, be used directly for irrigation and might be exchanged for potable water from wells now pumped for irrigation. An exchange, in which recharge from spring water applied to irrigated fields balances water pumped from wells for municipal use, would have little effect on the existing hydrologic regime.

Use of the total fresh-water flow at the Pearl Harbor springs and the use of wells only to meet the demands in excess of spring flow 
would permit a minimum of pumpage from wells in the Pearl Harbor area. At times when the demand exceeds the spring flow and pumpage from wells makes up the difference, the use of wells would take water from storage, lower the heads, and decrease the spring flow. On the other hand, when the demand is low, a reduction in pumpage from wells would result in water entering storage, a rise in heads, and an increase in spring flow. Because of seasonal and other fluctuations in spring discharge, the use of total spring flow in this manner would require flexibility in pumping capacities at both springs and wells. Increased use of spring water on irrigated fields overlying the part of the aquifer inland from the caprock would increase the recharge to the aquifer.

The direct effects of the total use of spring water would be mainly on the aquifer in the Pearl Harbor area (area 6). No leakage from areas 1 and 5 in Honolulu and area 11 west of Pearl Harbor escapes to the sea at the Pearl Harbor springs, and probably little water from area 2 in Honolulu discharges at the springs. The amount of increased pumpage in areas 1-5 and in area 11 will be controlled ultimately by the salinity of the water.

\section{ARTIFICIAL RECHARGE OF FLOODWATER}

Most of the surface runoff in the Pearl Harbor area consists of storm flow that cannot be utilized without storage, but storage is difficult because of the scarcity of water-tight reservoir sites. Leaky detention reservoirs, however, might be a means of recharging the aquifer with floodwater that at present flows into the sea. A large part of the $30 \mathrm{mgd}$ of surface runoff in the Pearl Harbor area could possibly be salvaged in this way, but further study is needed to determine the engineering and economic feasibility of increasing recharge by this method. Diversion of stream water into tunnels has already been considered as a means of recharge in the Honolulu area (Wentworth, 1951, p. 103).

\section{QUALITY OF WATER}

\section{SOURCES OF DISSOLVID SOLTDS}

On Oahu the sources of the dissolved constituents in water are the sea, the atmosphere, the mantle of soil and vegetation, the rocks through which the water passes, fertilizer salts, and sewage. The most important source of dissolved solids is the sea. It underlies and becomes mixed with the fresh water in the principal basal aquifers. It is the source of the salt nuclei in raindrops, and sea spray blown onto the land is dissolved by the descending rain. In regions where 
mixing of sea water with fresh ground water does not occur, such as at the top surface of inland portions of a thick fresh-water lens or in dike compartments, the mantle of soil and vegetation through which water moves contributes an important fraction of the dissolved solids. In these regions, also, the rocks containing the water are an important source of dissolved material. Soluble fertilizer salts are of significance in agricultural areas. The effect of sewage may be important locally, but it is negligible regionally. The atmosphere contributes dissolved gases, most of which react with material at the earth's surface to form ionized constituents.

The chemical composition of natural water is commonly reported in terms of the major dissolved ions and molecules. The principal cations are calcium $\left(\mathrm{Ca}^{+2}\right)$, magnesium $\left(\mathrm{Mg}^{+2}\right)$, sodium $\left(\mathrm{Na}^{+}\right)$and potassium $\left(\mathbf{K}^{+}\right)$; the principal anions are chloride $\left(\mathrm{Cl}^{-}\right)$, sulfate $\left(\mathrm{SO}_{4}{ }^{-2}\right)$, bicarbonate $\left(\mathrm{HCO}_{3}^{-}\right)$, nitrate $\left(\mathrm{NO}_{3}{ }^{-}\right)$, phosphate $\left(\mathrm{PO}_{4}^{-3}\right)$, and fluoride $\left(\mathrm{F}^{-}\right)$. The dissolved but un-ionized silica $\left(\mathrm{SiO}_{2}\right)$ molecule is also included as a principal constituent. Much of the calcium, magnesium, sodium, potassium, and sulfate and practically all the chloride are derived from sea water, but only a negligible fraction of the silica, nitrate, phosphate, and fluoride comes from the ocean. Some bicarbonate also originates in sea water. Soil and rock contribute significant quantities of calcium, magnesium, sodium, and potassium and virtually all the silica, phosphate, and fluoride. Most of the bicarbonate results from reaction of dissolved carbon dioxide with vegetative matter and soil. Nitrate comes from the atmosphere and the leaching of plant residue. In agricultural regions fertilizer salts add small amounts of calcium, potassium, nitrate, and sulfate and possibly very small quantities of phosphate, fluoride, and chloride. The only determinable addition from sewage is nitrate.

\section{EXPRESSION OF ANALYSES}

The dissolved mineral constituents in water are expressed normally in parts per million ( $\mathrm{ppm}$ ). One part per million is a unit weight of a constituent in a million unit weights of water. A common practice in Hawaiian agriculture is to report the salinity of water in terms of grains of sodium chloride $(\mathrm{NaCl})$ per gallon of water. To convert chloride content in parts per million to sodium chloride content in grains per gallon divide parts per million of chloride by the factor 10.39 .

The dissolved constituents may also be expressed in equivalents per million (epm). An equivalent per million is calculated by dividing the concentration in parts per million by the chemical combining weight of the constituent. For convenience in making this conversion, 
the reciprocals of chemical combining weights of the commonly reported ions are given in the following tabulation:

\begin{tabular}{|c|c|c|c|}
\hline Calcium $\left(\begin{array}{c}I 0 n \\
\left(\mathrm{Ca}^{+2}\right)_{-}\end{array}\right.$ & $\begin{array}{l}\text { Factor } \\
0.0499\end{array}$ & $\begin{array}{cc}\text { Ion } \\
\text { Sulfate } & \left(\mathrm{SO}_{4}^{-2}\right)\end{array}$ & $\begin{array}{r}\text { Factor } \\
0.0208\end{array}$ \\
\hline Magnesium $\left(\mathrm{Mg}^{+2}\right)$ & .0822 & Chloride $\left(\mathrm{Cl}^{-}\right)_{-}$ & .0282 \\
\hline Sodium $\left(\mathrm{Na}^{+}\right)$ & .0435 & Fluoride $\left(F^{-}\right)_{--}$ & .0526 \\
\hline Potassium $\left(\mathrm{K}^{+}\right)$ & .0256 & Nitrate $\left(\mathrm{NO}_{3}^{-}\right)_{-}$ & .0161 \\
\hline Bicarbonate $\left(\mathrm{HCO}_{3}^{-}\right)$ & .0164 & & \\
\hline
\end{tabular}

Hardness of water, reported generally as calcium carbonate $\left(\mathrm{CaCO}_{3}\right)$, is calculated from the equivalents of calcium and magnesium. 'The hardness caused by these ions is called carbonate hardness; the hardness in excess of this quantity is called noncarbonate hardness. Unless otherwise specified, only the carbonate hardness is referred to.

The $\mathrm{pH}$ of a solution is a measure of the hydrogen-ion concentration and is an expression of the acidity or alkalinity of water. Water having a $\mathrm{pH}$ value of 7.0 is neither acid nor alkaline. Waters having $\mathrm{pH}$ values progressively lower than 7.0 have increasing acidity, and those having values progressively higher than 7.0 have increasing alkalinity. The pH of most of the waters in Oahu is close to 7.0. The pH of rainwater is characteristically low, generally between 5.0 and 6.0 ; the $\mathrm{pH}$ of stream waters normally falls betwen 7.0 and 7.5 ; and the $\mathrm{pH}$ of ground water falls between 7.0 and 8.0. The $\mathrm{pH}$ of ocean water falls between 7.5 and 8.4 (Sverdrup, and others, 1946, p. 194).

Specific conductance is expressed in micromhos at $25^{\circ} \mathrm{C}$. Specific conductance is a measure of the ability of the water to conduct an electric current. Conductance varies with the concentration and degree of ionization of the different constituents in solution and with the temperature of the water. In this report, because of the dominance of the chloride ion in most samples of water, the specific conductance is generally correlated with the chloride concentration.

\section{QUALITY IN RELATION TO USE OF THE WATER}

Water supplies of southern Oahu are used for domestic, industrial, and agricultural purposes. Domestic supplies are obtained mainly from wells and tunnels, most of which tap basal water in the lava flows of the Koolau Volcanic Series. All water for domestic use distributed by government utilities is safely within the standards of potability recommended by the United States Public Health Service (1962). Table 2 lists the limits established by this agency and compares them with a typical analysis of the most saline water provided by a government utility on Oahu and with a typical analysis of water provided by the Honolulu Board of Water Supply. 
TABLE 2.-Comparison of quality of water, in parts per million, from shaft 14 and well 88 with drinking water standards of the U.S. Public Health Service

[Shaft 14, analysis by U.S. Navy; Barbers Point Naval Air Station supply. Well 88, analysis by Honolulu Board of Water Supply; water supply for part of Honolulu]

\begin{tabular}{|c|c|c|c|}
\hline & U.S.P.H.S. & Shaft 14 & Well 88 \\
\hline \multicolumn{4}{|c|}{ Mandatory limits } \\
\hline $\begin{array}{l}\text { Lead } \\
\text { Fluoride. } \\
\text { Arsenic } \\
\text { Selenium } \\
\text { Hexavalent chromium }\end{array}$ & $\begin{array}{l}0.05 \\
.8 \\
.05 \\
.01 \\
.05\end{array}$ & $\begin{array}{l}<0.02 \\
\sum .1 \\
\sum .02 \\
<.05\end{array}$ & $\begin{array}{r}<0.02 \\
<.05 \\
<.02 \\
<.02 \\
<.02\end{array}$ \\
\hline
\end{tabular}

Recommended limits

\begin{tabular}{|c|c|c|c|}
\hline $\begin{array}{l}\text { Copper } \\
\text { Iron } \\
\text { Chloride. } \\
\text { Sulfate } \\
\text { Nitrate- } \\
\text { Total solids, desirable }\end{array}$ & $\begin{array}{r}1.0 \\
250 \\
250 \\
45 \\
500\end{array}$ & $\begin{array}{l}<0.02 \\
220.07 \\
220 \\
56 \\
9.5 \\
675\end{array}$ & $\begin{array}{l}<0.02 \\
\text { <. } 02 \\
39 \\
5.9 \\
211\end{array}$ \\
\hline
\end{tabular}

In general, the chloride content is used in defining the potability of Hawaiian waters. All or most of the chloride is derived from sea water, and sea water is the principal source of dissolved solids in fresh water. Therefore, the chloride content is used as an index of the chemical quality of the water. The chloride ion does not enter into chemical reactions with other constituents in its environment, nor is it subject to appreciable ion exchange. In sea water it maintains a constant ratio to the other principal constituents in solution, and this same proportionality prevails approximately when the sea water mixes with fresher water.

The greatest utilization of water in southern Oahu is in agriculture, especially for the irrigation of sugarcane. No well-defined limits have been established for the quality of water suitable for irrigation on Oahu, but the consensus is that the major crop, sugarcane, cannot be grown economically if the water contains more than about $1,000 \mathrm{ppm}$ of chloride. Although the quality of irrigation water is conveniently estimated by its chloride content, its useability in terms of both sodium (alkali) hazard and salinity hazard must be considered. The classification of irrigation water as recommended by the U.S. Salinity Laboratory Staff (1954) is based on the specific conductivity in micromhos and the sodium-adsorption ratio of the water. Specific conductance indicates the degree of salinity of the water, which, for water of Oahu, is indicated by the chloride content.

The sodium hazard is evaluated by the sodium-adsorption-ratio (SAR), which indicates the extent to which soil will absorb sodium 
from the water and the rate of adsorption as the water is applied. The SAR is obtained from the following relation suggested by the U.S. Salinity Laboratory Staff $(1954$, p. 72$)$ :

$$
S A R=\frac{N a^{+}}{\sqrt{\frac{C a^{+2}+M g^{+2}}{2}}}
$$

In this formula the ionic concentrations are expressed in equivalents per million. A ratio for potassium adsorption (PAR) can be obtained in a similar way, but the hazard from potassium adsorption is not considered significant for Oahu waters.

The classification of irrigation water as suggested by the U.S. Salinity Laboratory Staff $(1954$, p. 80$)$ is shown in figure 33 . According to this report, the degree of conductivity delineates four categories of salinity hazard. Low-salinity water (C1) can be used for most crops on most soils with little likelihood that soil salinity will occur. Medium-salinity water $(\mathrm{C} 2)$ can be used if a moderate amount of leaching occurs. Plants with moderate salt tolerance can generally be grown without special practices for salinity control. High-salinity water (C3) cannot be used on soils having restricted drainage. Only plants having good salt tolerance can utilize this water. Very high salinity water (C4) is not suitable for irrigation under ordinary conditions but may be used under special circumstances: the soils must be permeable, drainage must be adequate, irrigation water must be applied in excess to provide considerable leaching, and salt-tolerant crops should be selected. The conditions of permeability and drainage necessary for use of $\mathrm{C} 3$ and $\mathrm{C} 4$ waters are largely met by the latosols on which much of the sugarcane on Oahu is grown, and irrigation water is applied in excess for this crop. The principal limiting factor in using high salinity irrigation water on latosols seems to be the degree of salinity tolerance of the sugarcane plant. The hydromorphic soils that cover a sizeable acreage of cane near the coast would be subject to salinity hazard. The practice of excessive application of irrigation water inhibitsthis danger, however.

The SAR delineates four categories of sodium hazard for irrigation water. Low-sodium water (S1) can be used for irrigation on almost all soils with little danger of reaching harmful levels of exchangeable sodium. Medium-sodium water (S2) presents an appreciable sodium hazard in fine-textured soils having high cation exchange capacity, especially under low leaching conditions. High-sodium water (S3) may produce harmful levels of exchangeable sodium in most soils, and the soils would require special management. Very 
BASAL GROUND WATER IN SOUTHERN OAHU

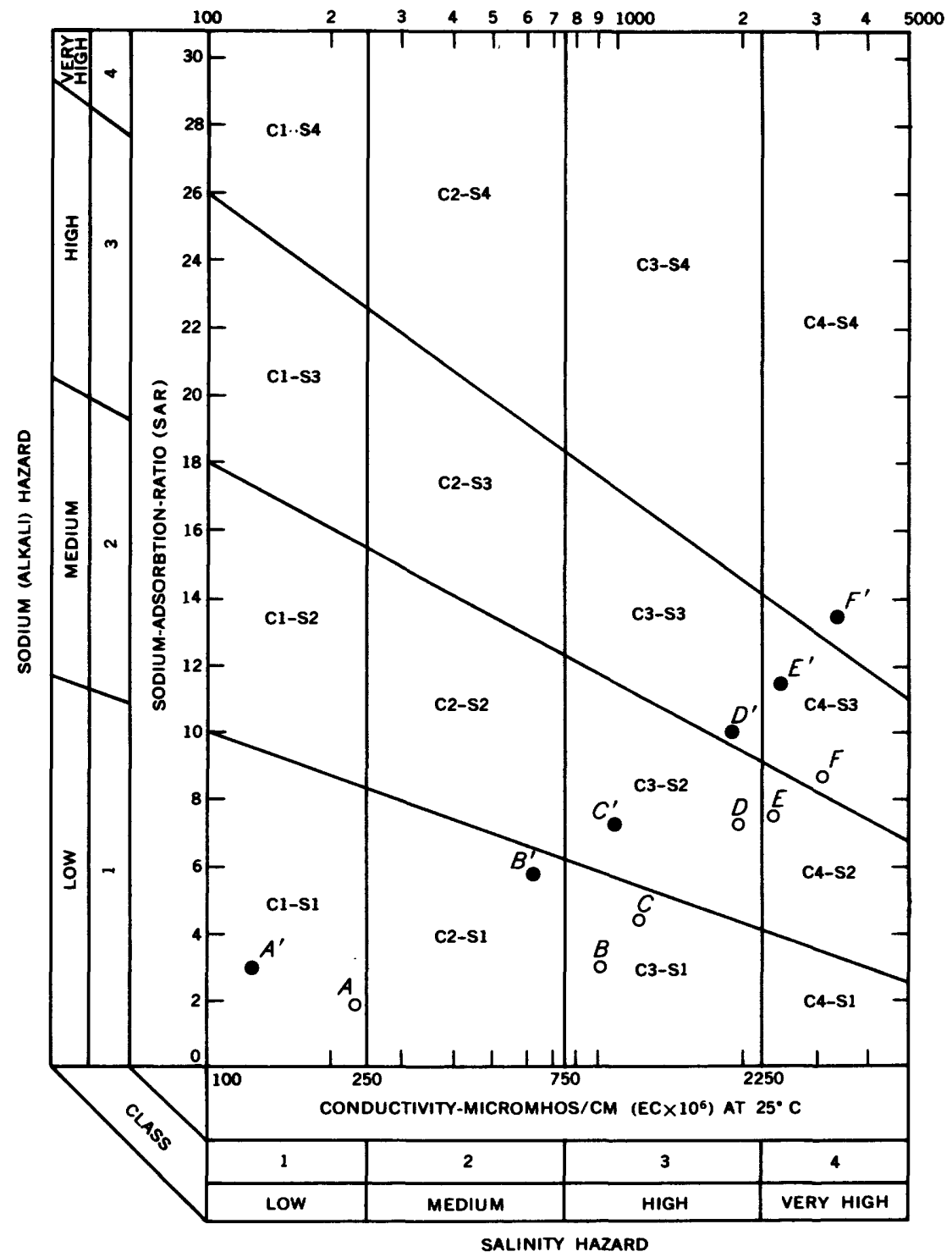

Figure 33.-Diagram classifying water on the basis of sodium (alkali) and salintty hazards. Points $A-F$ (open circles) represent ground water of different chloride content from southern $O a h u$, and points $A^{\prime}-F^{\prime}$ (solid circles) represent sea water diluted to the same chloride contents as the ground water samples.

high sodium water (S4) is generally unsatisfactory for irrigation except at low and perhaps medium salinity.

Because of the good drainage characteristics of the latosols of Oahu and the large amounts of irrigation water applied, the latosols effec- 
tively resist alkalization, even where high sodium waters are applied. The hydromorphic soils on the Ewa Plain and along the coast are susceptible to the sodium hazard of high sodium water because of their poor permeability and relatively high ion-exchange capacity. The water used for irrigation, on Oahu, however, does not ordinarily contain excessive sodium in relation to calcium and magnesium and therefore does not have a high sodium hazard.

Specific-conductance and SAR data for six samples of typical irrigation water in the Pearl Harbor area of Oahu are plotted on figure 33. Data are plotted also for sea water diluted to the same chloride content as the irrigation water samples. Table 3 presents data on the salinity and sodium hazard of these samples. The chloride content of the water is included in the table because it correlates very closely with both the cation content of the water and with the specific conductivity and can therefore be used as an indicator of the salinity and sodium hazard. The high-salinity hazard for the irrigation waters occurs at relatively low chloride values, but the sodium hazard is dangerous only in waters containing about $1,000 \mathrm{ppm}$ of chloride, the extreme upper limit commonly accepted in sugarcane irrigation.

It is interesting to compare on the graph in figure 33 the positions of the irrigation water with those for sea water diluted to the same

TABLE 3.-Comparison of salinity and sodium hazard with cation content and specific conductance of ground water from several sources in southern Oahu and of sea water diluted to the same chloride content

[C1, low salinity; C2, medium salinity; C3, high salinity; C4, very high salinity. S1, low sodium; Ś2, medium sodium; S3, high sodium; S4, very high sodium]

\begin{tabular}{|c|c|c|c|c|c|c|c|c|}
\hline \multirow{2}{*}{ Sample } & \multirow{2}{*}{$\begin{array}{l}\text { Speciflc } \\
\text { conduct- } \\
\text { ance } \\
\text { (micro- } \\
\text { mhos at } \\
25^{\circ} \mathrm{C} \text { ) }\end{array}$} & \multicolumn{2}{|c|}{ Chloride (Cl) } & \multirow{2}{*}{$\begin{array}{c}\text { Calcium } \\
\text { (Ca) } \\
\text { (epm) }\end{array}$} & \multirow{2}{*}{$\begin{array}{l}\text { Magnesium } \\
(\mathbf{M g})(\text { epm) }\end{array}$} & \multirow{2}{*}{$\begin{array}{c}\text { Sodium } \\
\text { (Na) } \\
\text { (epm) }\end{array}$} & \multirow{2}{*}{ SAR } & \multirow{2}{*}{$\begin{array}{l}\text { Salinity- } \\
\text { sodium } \\
\text { hazard }\end{array}$} \\
\hline & & Ppm & Epm & & & & & \\
\hline
\end{tabular}

Ground water

\begin{tabular}{|c|c|c|c|c|c|c|c|c|}
\hline $\begin{array}{l}\mathbf{A} \\
\mathbf{B} \\
\mathbf{C} \\
\mathbf{D} \\
\mathbf{E} \\
\mathbf{F}\end{array}$ & $\begin{array}{r}248 \\
916 \\
1,145 \\
2,000 \\
2,560 \\
\mathbf{3}, \mathbf{3 4 0}\end{array}$ & $\begin{array}{r}38 \\
184 \\
284 \\
559 \\
745 \\
1,000\end{array}$ & $\begin{array}{l}1.072 \\
5.189 \\
8.009 \\
15.76 \\
21.01 \\
28.20\end{array}$ & $\begin{array}{l}0.469 \\
1.450 \\
1.901 \\
2.850 \\
3.290 \\
4.645\end{array}$ & $\begin{array}{l}0.674 \\
2.550 \\
2.302 \\
3,535 \\
5.500 \\
7.650\end{array}$ & $\begin{array}{r}1.075 \\
3.872 \\
6.003 \\
12.27 \\
15.13 \\
20.16\end{array}$ & $\begin{array}{l}1.42 \\
2.70 \\
4.14 \\
6.85 \\
7.21 \\
8.26\end{array}$ & $\begin{array}{l}\text { C1-S1 } \\
\text { C3-S1 } \\
\text { C3-S1 } \\
\text { C3-S2 } \\
\text { C4-S2 } \\
\text { C4-S3 }\end{array}$ \\
\hline
\end{tabular}

Diluted sea water

\begin{tabular}{|c|c|c|c|c|c|c|c|c|}
\hline $\begin{array}{l}\mathbf{A}^{\prime} \\
\mathbf{B}^{\prime} \\
\mathbf{C}^{\prime} \\
\mathbf{D}^{\prime} \\
\mathbf{E}^{\prime} \\
\mathbf{F}^{\prime}\end{array}$ & $\begin{array}{r}127 \\
613 \\
947 \\
1,863 \\
2,483 \\
3,430\end{array}$ & $\begin{array}{r}38 \\
184 \\
284 \\
559 \\
745 \\
1,000\end{array}$ & $\begin{array}{l}1.072 \\
5.189 \\
8.009 \\
15.76 \\
21.01 \\
28.20\end{array}$ & $\begin{array}{r}0.0399 \\
.1946 \\
.2994 \\
.5888 \\
.7834 \\
1.048\end{array}$ & $\begin{array}{l}0.2055 \\
1.011 \\
1.562 \\
3.083 \\
4.110 \\
\text { 5. } 507\end{array}$ & $\begin{array}{r}0.9135 \\
4.437 \\
6.873 \\
13.485 \\
18.009 \\
24.186\end{array}$ & $\begin{array}{r}2.61 \\
5.70 \\
7.11 \\
9.95 \\
11.50 \\
13.35\end{array}$ & $\begin{array}{l}\text { C1-S1 } \\
\text { C2-S1 } \\
\text { C3-S2 } \\
\text { C3-S3 } \\
\text { C4-S3 } \\
\text { C4-S4 }\end{array}$ \\
\hline
\end{tabular}

A. Shaft 12, analyses by Honolulu Board of Water Supply.

B. Shaft 3, analyses by Honolulu Board of Water Supply.

C. Well 249 , analyses from Stearns and Vaksvik $(1938, \mathrm{p}$. 364).

D. Well 248 , analyses from Stearns and Vaksvik (1938, p. 364).

$\mathbf{E}$ aud F. Well 201, analyses by U.S. Geol. Survey. 
chloride content. The diluted sea-water samples present relatively higher sodium hazard and lower salinity hazard. The sodium hazard of sea water diluted to a chloride content of $500 \mathrm{ppm}$ is as great as that for ground water having $1,000 \mathrm{ppm}$ of chloride. This comparison shows that the saline water underlying the fresh-water lens differs in its cation proportions from true sea water, the cation balance favoring lower sodium content. This phenomenon is caused by ion exchange that takes place when the sea water migrates under the island.

Industrial users of the water in southern Oahu draw on municipal systems and on private wells and springs for their supplies. The quality of the water required by industry depends on the process using the water. The characteristic most commonly considered in determining quality is the hardness. Water that has less than $60 \mathrm{ppm}$ of carbonate hardness is usually rated as soft and as suitable for many purposes without further softening. Water having a hardness ranging from 61 to $120 \mathrm{ppm}$ is considered moderately hard, but this degree of hardness does not seriously interfere with the use of water for most purposes other than in high-pressure steam boilers. Water having a hardness ranging from 121 to $180 \mathrm{ppm}$ is considered hard, and laundries and industries profitably soften such supplies. Water having hardness greater than $181 \mathrm{ppm}$ generally requires some softening before being used for most purposes.

The hardness of Hawaiian waters can be correlated with chloride content as the hardness generally increases with chloride content. Figure 34 is a plot of hardness as a function of chloride content for ground water in areas where a wide range of chloride values are available. The relation indicates that hardness is determined mainly by the amount of mixing of sea water with fresh.

The correlation may deviate from a direct linear relation at low chloride concentrations; this deviation indicates little mixing between saline water and fresh. At the low concentrations the hardness contributed by saline water is less than that from the solution of rock. The relationship between hardness and chloride content of sea water at all dilutions is plotted in figure 34 to illustrate the differences between diluted sea water and the ground water. The hardness of the ground water is greater than that of sea water diluted to comparable chloride content because the saline water underlying the lens has a greater calcium and magnesium content than the sea water.

\section{GEOCHEMICAL CYCLE}

\section{RAINFALI}

Rainfall is the source of fresh water in the Hawaiian Islands. On Oahu, which is relatively small in area and where large amounts of 


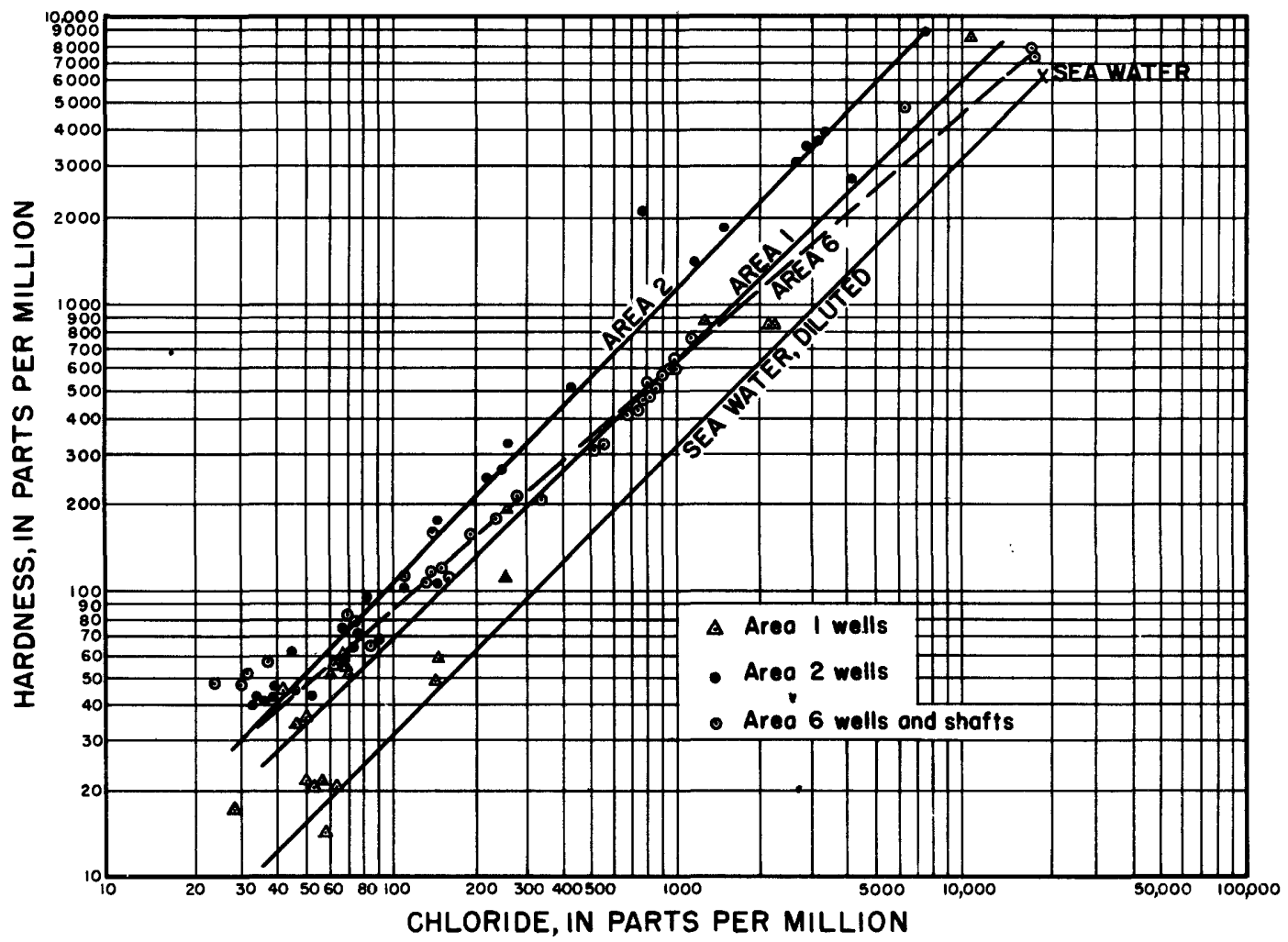

FIGURE 34.-Curves showing relation between hardness and chloride content of ground water in several areas in southern Oahu and of diluted sea water. 
water are developed, the immediate importance of the rainfall is particularly evident. Because of the nearness of high-rainfall areas to the zones of discharge into the sea and the readily conceived relationship between rainfall, runoff, and ground water, an understanding of the chemistry of the water as it moves through the cycle is important to a knowledge of the hydrologic cycle of the island.

The origin of water as rainfall on Oahu is the sea. Water vapor from the sea condenses into drops around sea-salt nuclei originating in the ocean and falls as rain. Thus, the principal source of the dissolved constituents of rainwater on the island is the sea. Other dissolved constituents are derived from the gases of the atmosphere, from industrial contamination, and from dust. The atmospheric contribution consists chiefly of nitrogen-generally as nitrate or ammonium-carbon dioxide, and oxygen. Industrial contaminants are generally insignificant except locally near urbanized areas. Wind-blown dust may be important in agricultural regions.

No complete chemical analyses are known to have been made of rainfall on Oahu. The most dependable chemical analyses of rainwater in the Hawaiian Islands were made of rainwater collected on the island of Hawaii by Eriksson (1957, p. 509-520). However, several chloride analyses have been made of Oahu rainfall in previous investigations (Stearns and Vaksvik, 1935, p. 346; Bryson, L. T., 1951, unpublished data, Honolulu Board of Water Supply), and during the present study chloride contents of rainwater were determined on monthly catches in rain gages in the Kipapa Stream basin during 1957. Eriksson's analyses were made of orographic rain at the sea coast near Hilo and at various altitudes on the windward slope of Mauna Kea.

The rainfall on all the islands of Hawaii has a smiliar origin and falls as the result of similar causes; therefore, its chemical quality at comparable locations is likely to be similar. By relating the chloride data obtained in the high rainfall area of Kipapa Stream on Oahu to those given by Eriksson for the high rainfall area on Mauna Kea, one can estimate the chemical quality of the rainwater in the wet Koolau Mountains of Oahu. Also, the chemical quality of the rainwater on coastal areas of Oahu, which have low rainfall, can be estimated by relating the chloride content to that obtained by Eriksson at a coastal location near Hilo. No data are available on the chloride content of rainfall in the region between the high and low rainfall areas on Oahu, but the salinity is probably gradational between these areas.

Table 4 gives the average composition of rainwater caught in high and low rainfall locations on Oahu and Hawaii. Eriksson's (1957, 
p. 520) samples from high rainfall areas were collected during two 2-day periods on the slopes of Mauna Kea between altitudes of 1,300 and 2,700 feet. His samples had chloride contents ranging from 1.12 to $6.87 \mathrm{ppm}$. The average chloride value shown for the part of the Kipapa Stream basin that is similar to the slopes of Mauna Kea in altitude, distance from the sea, and annual rainfall (100-250 inches) was determined for monthly catches of rain during 1957 . The individual samples ranged from 2.0 to $10.0 \mathrm{ppm}$ in chloride content. The other dissolved constituents, with the exception of nitrate, were calculated by assuming that the ratio of each to chloride was the same as for both Mauna Kea samples.

TABLE 4.-Average composition of rainfall caught at high-and low-rainfall localities on Hawaii and Oahu

[Constituents in parts per million]

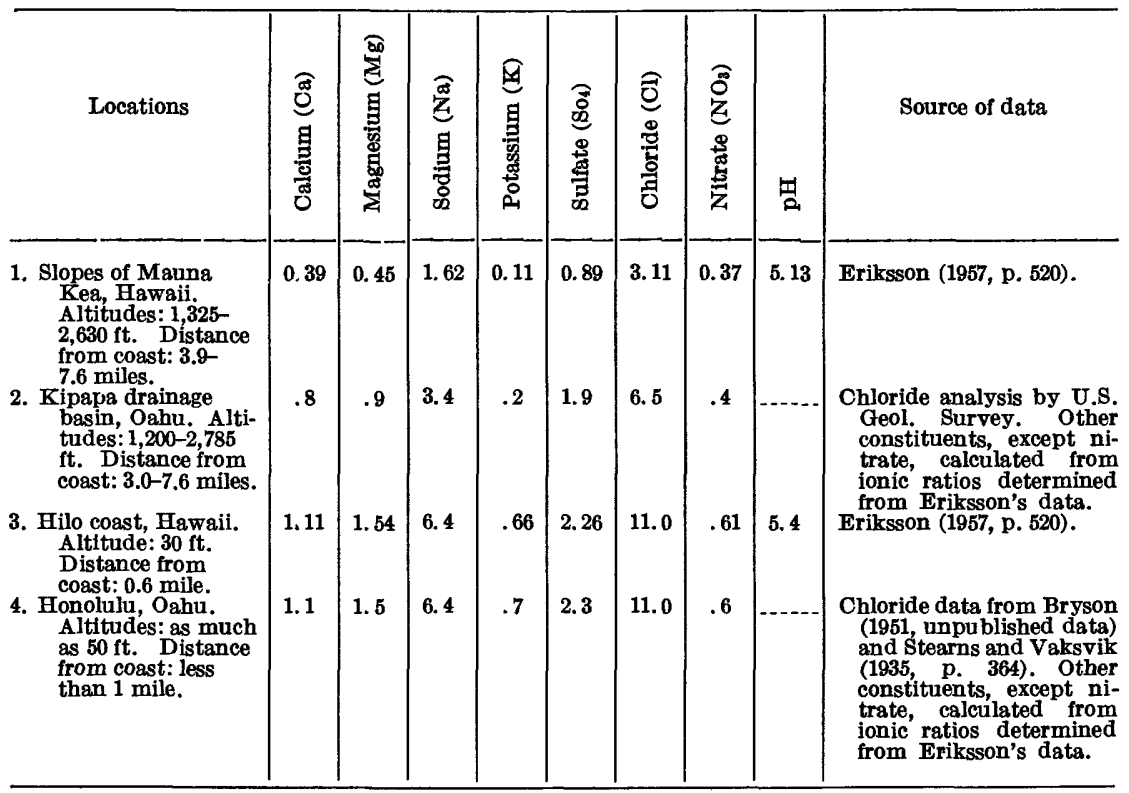

The constant ratio of each constituent to chloride was assumed because sea salt is the principle source of the dissolved solids. The actual ratios in the rainwater, however, do not correspond exactly to those in sea water. By use of chloride as the reference, more calcium, magnesium, sulfate, and potassium are calculated to occur in the rainwater than in sea water. Sodium content is approximately the same as that in sea water diluted to the same chloride content. The ratios are so close for all these dissolved constituents, however, and the 
absolute quantities are so small that the ratios probably can be regarded as constant.

Only a negligible quantity of nitrate could be expected in the seasalt component, and its concentration for comparable rainfall areas is regarded as constant.

On first consideration a 1-month period of accumulation of rainfall in the rain gages in Kipapa Stream basin would seem to give unreliable chloride data because the fallout of salt nuclei would cause greater chloride concentrations in small accumulation of rainfall than in large. However, figure 35 , in which the chloride content of samples collected about once a month is plotted as a function of rainfall in the Kipapa Stream basin, shows that the chloride content does not vary significantly with the amount of rainfall in a region of high ranfall. Data supporting this conclusion are contained in a paper by Woodcock and Blanchard $(1955$, p. 437). They reported that the average chloride content of the moisture in orographic clouds over Hawaii is 4.8 milligrams per liter. This figure is near the average of $6.5 \mathrm{ppm}$ obtained in the Kipapa Stream basin. Thus, most of the chloride in rainwater collected in high rainfall areas is probably contributed by the rain itself.

Table 4 shows also the chemical composition of rainfall in coastal regions. The data suggest the upper limit of the dissolved constituents of rainwater under normal conditions. Eriksson's (1955, p. 520) samples were obtained near Hilo during two 24-hour periods, and the Honolulu samples were obtained from single but different showers.

Only the chloride content was determined for the Honolulu samples, and the other constituents are assumed to have the same ratio to the chloride content as in the Hilo samples. The average of Eriksson's chloride data is identical to that for the Honolulu samples. Chloride contents of Eriksson's individual rain samples ranged from 5.2 to $16.8 \mathrm{ppm}$; the chloride contents of rain at Honolulu ranged from 3.0 to $29.0 \mathrm{ppm}$.

The data in table 4 show that in the principal recharge area of southern Oahu, the wet Koolau Mountains, the rainfall contains a minimum of about $14.5 \mathrm{ppm}$ of dissolved solids, almost half of which is chloride. The principal unreported constituents would include bicarbonate $\left(\mathrm{HCO}_{3}{ }^{-}\right)$and dissolved oxygen and carbon dioxide. No determinations for silica are given, but the silica content is probably insignificant. Near the coast the dissolved-solids content is nearly twice that in the mountainous regions of high ranifall; but recharge at the coast is negligible, and the chemistry of the rainwater here is not important in the interpretive geochemistry of ground and surface waters. The relatively low $\mathrm{pH}$ of the rainwater (5.13-5.4) in both the low and high 


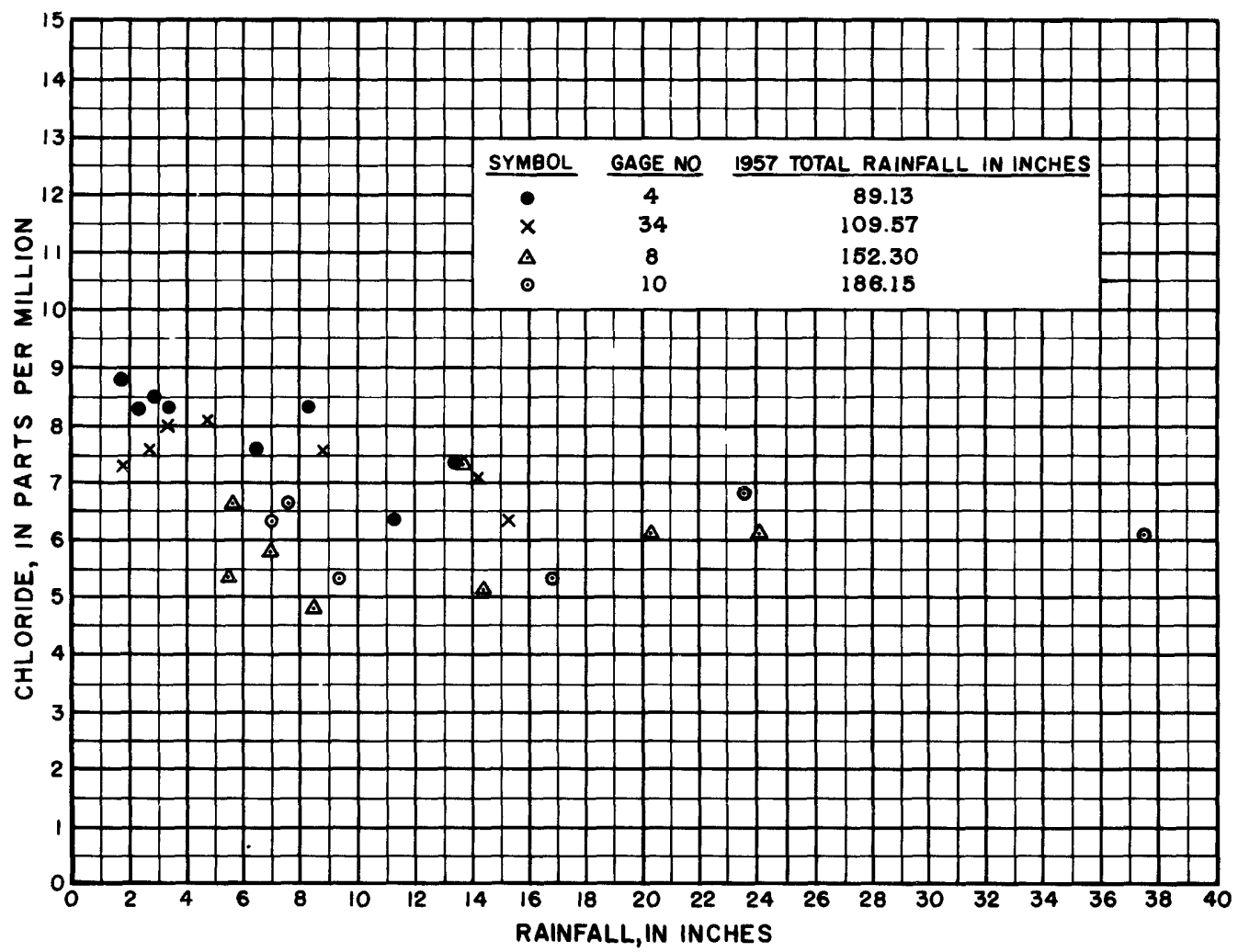

FIGURE 35.- Scatter diagram showing relationship between chloride content of rainwater and amount of rainfall during monthly intervals in 1957. 
rainfall areas is significant because it indicates that the rainwater has a relatively high reactivity, which is important in weathering processes. Between the coast and the wet mountains, the amount of dissolved constituents in the rainfall is probably intermediate between the values given for the two areas.

\section{SEA WATER}

Sea water surrounds Oahu, and it moves into the permeable rocks of the island from all sides. Unless it is restrained by impermeable structures such as dikes, fresh water, in accord with the Ghyben Herzberg principle, forms a lens that floats on the heavier saline water. At the boundary between the fresh and saline water, mixing of the two greatly alters the chemical quality of the fresh water. Mixing is caused principally by mechanical action resulting from tides and from variations in recharge and discharge. The effect of ionic diffusion is relatively minor.

Sea water in the open ocean is strikingly homogeneous in its composition throughout the world. Table 5, taken from Sverdrup, Johnson, and Fleming (1946, p. 173, and 176-177), lists the major constituents of sea water and minor ones that are important in terrestrial

TABLE 5.-The composition of sea water

[After Sverdrup, Johnson, and Fleming, 1946]

\begin{tabular}{|c|c|c|}
\hline \multirow{2}{*}{ Constituent } & \multicolumn{2}{|c|}{ Concentration } \\
\hline & Ppm & Epm \\
\hline \multicolumn{3}{|l|}{ Anions } \\
\hline $\begin{array}{l}\mathrm{Cl} \\
\mathrm{SO}_{4} \\
\mathrm{HCO}_{4} \mathrm{Br}_{3} \\
\mathrm{~F}_{1}\end{array}$ & $\begin{array}{r}18,980 \\
2,649 \\
140 \\
65 \\
1.3 \\
0.05-3.1\end{array}$ & $\begin{array}{r}\text { 535. } 3 \\
\text { 55. } 10 \\
2.296 \\
.8133 \\
.0684 \\
\text { 0. } 008-.0499\end{array}$ \\
\hline \multicolumn{3}{|l|}{ Cations } \\
\hline 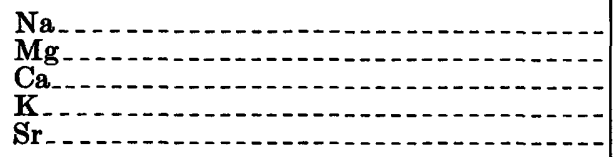 & $\begin{array}{r}10,561 \\
1,272 \\
400 \\
380 \\
13\end{array}$ & $\begin{array}{l}\text { 459. } 4 \\
\text { 104. } 6 \\
\text { 19. } 96 \\
9.728 \\
.2967\end{array}$ \\
\hline
\end{tabular}

Undissociated

\begin{tabular}{l|r|r}
\hline Boric Acid $\left(\mathrm{H}_{3} \mathrm{BO}_{3}\right)$ & 14 & \\
Silica $\left(\mathrm{SiO}_{2}\right)$ & $0.04-8.6$ & \\
\hline
\end{tabular}

1 All nitrogen computed as $\mathrm{NO}$. 
waters. The composition of the saline water on which the fresh water floats is not identical to sea water, however, because of changes that the sea water undergoes as it passes through the ocean bottom and into the rocks of the island. These changes chiefly affect the amounts of dissolved ealcium, magnesium, sodium, potassium, and sulfate in the sea water. The chloride content remains unchanged, as it is virtually inert to chemical and adsorption reactions, and because of its high concentration, it is used as an index in measuring changes that occur in the concentration of other constituents.

EFFECT OF TERRESTRIAL ENVIRONMENT ON RATNWATER

Extensive changes take place in the chemical composition of rainwater after it falls. It first reacts with the layer of vegetation and soil, after which it runs off in streams or percolates underground. The percolating water reacts with its rock environment, promoting the decomposition of the rock and creating a zone of weathering that is commonly about 100 feet thick. This weathered zone, which is poorly defined owing to the decreasing intensity of reaction with depth, is the region of greatest change in the composition of the water. Additional changes in the water may occur in the mass of permeable rock below the weathered zone, but they do not compare in significance with the changes that occur in the overlying mantle.

Most of the surface and ground waters of southern Oahu is on or in the rocks of the Koolau Volcanic Series. Most of the ground water in the rocks of the Waianae Volcanic Series probably moved into them from the basalt of the Koolau Volcanic Series. No perennial streams flow over rocks of the Waianae. The area of highest rainfall and ground-water recharge occurs in the Koolau Range, and more than half the irrigation water is applied to fields overlying the basalt of the Koolau Volcanic Series. East of Pearl Harbor the rocks of the Honolulu Volcanic Series irregularly overlie the Koolau Volcanic Series, but they contain little ground water. Thus, the chemical quality of the ground and surface waters of southern Oahu is dominated by the effects of the rocks of the Koolau Volcanic Series, although locally the effects of the Honolulu and Waianae Volcanic Series may be noticeable.

The most common minerals in the volcanic rocks of southern Oahu are calcic plagioclase, pyroxenes, olivine, magnetite, ilmenite, and small amounts of apatite. Glass is also common. The Honolulu Volcanic Series contains, in addition to the above minerals, the feldspathoids melilite and nephelite. The upper member of the Waianae Volcanic Series contains somewhat less calcic plagioclase than the Koolau and Honolulu Volcanic Series, but the difference is not great enough to alter the weathering of the rock. Rocks containing these 
mineral assemblages are high in calcium, magnesium, iron, aluminum, and combined silica, of which the calcium, magnesium, and silica are very mobile under weathering conditions of heavy rainfall and warm temperature. In addition, the rocks contain appreciable quantities of sodium and potassium, which leach even more readily. Where the annual rainfall exceeds about 60 inches, the rocks undergo relatively rapid laterization, in which they quickly lose the alkalies, alkaline earths, and much of the combined silica, leaving an end product composed mainly of hydrated oxides of iron and aluminum. However, complete laterization is rare, and the residue of weathering generally contains clay minerals in addition to the hydrated oxides. In some areas the proportion of the hydrated aluminum oxide is so high that the soils and weathered zone form low-grade bauxite deposits; in other areas the hydrated iron oxides may dominate.

Where the annual rainfall is less than about 60 inches, the laterization process is retarded; but the order of leaching is similar, and kaolinite-base soils develop. Of these, the low-humic latosol is most widespread in southern Oahu. Table 6 gives chemical analyses of the average basalt of the Koolau Volcanic Series and of two types

TABLE 6.-Representative chemical analyses, in percent, of basaltic rocks of Oahu and of soits derived from basalt

\begin{tabular}{|c|c|c|c|c|c|c|}
\hline Constituent & $\begin{array}{c}1 \\
\text { Basalt }\end{array}$ & \begin{tabular}{c}
$c$ \\
\multicolumn{1}{c}{} \\
Hydrol- \\
humic \\
latasol
\end{tabular} & $\begin{array}{c}3 \\
\text { Lithosol }\end{array}$ & $\begin{array}{c}4 \\
\text { Low- } \\
\text { humic } \\
\text { latasol }\end{array}$ & $\begin{array}{c}5 \\
\text { Basalt }\end{array}$ & $\begin{array}{c}6 \\
\text { Basalt }\end{array}$ \\
\hline 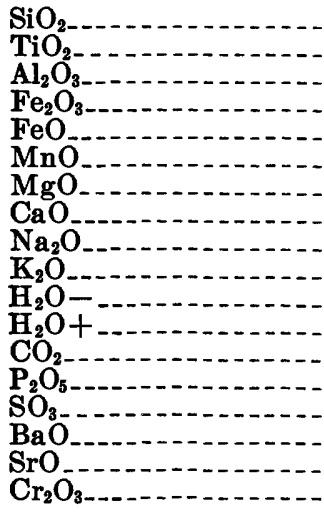 & $\begin{array}{r}50.45 \\
2.33 \\
14.94 \\
3.28 \\
7.55 \\
.08 \\
7.67 \\
9.17 \\
2.84 \\
.35 \\
.23 \\
.79 \\
.27 \\
.07 \\
-0 . \\
.05\end{array}$ & $\begin{array}{r}12.1 \\
6.0 \\
22.6 \\
28.2 \\
11.68 \\
14.92 \\
\end{array}$ & $\begin{array}{l}14.67 \\
26.90 \\
21.60\end{array}$ & $\begin{array}{r}33.87 \\
4.97 \\
24.87 \\
22.39 \\
.26 \\
.48 \\
.64 \\
.16\end{array}$ & $\begin{array}{r}49.18 \\
\text { 3. } 96 \\
\text { 13. } 92 \\
\text { 5. } 58 \\
6.63 \\
.21 \\
\text { 5. } 89 \\
8.54 \\
\text { 3. } 43 \\
.82 \\
1.14 \\
.73 \\
.60 \\
\\
\end{array}$ & $\begin{array}{r}\text { 37. } 12 \\
2.64 \\
11.43 \\
5.74 \\
\text { 8. } 19 \\
.12 \\
12.44 \\
13.50 \\
4.52 \\
1.07 \\
.37 \\
1.28 \\
.07 \\
1.16 \\
.21 \\
.11 \\
0.05 \\
.05\end{array}$ \\
\hline
\end{tabular}

1. Basalt, Koolan Volcanic Series. Average of 10 analyses (Wentworth, 1951, p. 13).

2. Hydrol-humic latasol of Hilo family (Cline, 1955, $\mathrm{p}$. 115).

3. Lithosol in basin of Kipapa Stream (Chinn, E. Y. H., 1936, unpublished data, Hawaii Univ., Honolulu).

4. Low-humic latasol of Lahaina family (Cline, 1955, p. 112).

5. Basalt, Waianae Volcanic Series. A verage of eight analyses. Excludes olivine-rich basalt and trachyte (Stearns and Macdonald, 1940, p. 91)

6. Nepheline basalt, Honolulu Volcanic Series. Average of six analyses (Wentworth. 1951, p. 19, column B).

I From analysis of colloidal fraction. 
of soils that develop on it. Analyses of a hydrol-humic latosol from Hawaii and a lithosol from the high rainfall area (90-240 inches per year) of Kipapa Stream basin are given to indicate the nature of the end product of basalt weathering under heavy rainfall and warm temperature. Although the soils in the wet part of Kipapa Stream basin are mapped as lithosols by Cline (1955), they are probably closely akin to the hydrol-humic latosols. An analysis of a low-humic latosol is included to illustrate the manner of leaching in regions of lower rainfall. In the drier regions the natural waters contain a greater quantity of dissolved constituents than in heavy-rainfall areas because of less dilution. Virtually all the components leached from the rock during weathering are transported in ground water.

Table 6 also gives the average composition of basalt of the Waianae Volcanic Series (composite of all three members) and of the Honolulu Volcanic Series. The soils that develop on these rocks are comparable to those that form on the Koolau Volcanic Series under similar climatic conditions.

\section{COMPOSITION OF UNCONTAMTNATED WATER}

Uncontaminated water as used here refers to the ground water and the surface water whose composition has not been affected by mixing with intruded sea water or by the addition of irrigation or other water affected by the activity of man. The principal occurrences of uncontaminated ground water are in dike compartments, in perched water bodies in mountain areas, and in the uppermost part of the fresh basal lens near the main area of mountain recharge. Uncontaminated stream water occurs in mountain areas free of agricultura? and urban activities.

\section{EXPRESSION OF COMPOSITION}

A sufficient number of water analyses from southern Oahu are available so that the composition of the water can be treated by statistical methods. In this study more than 500 complete analyses (those including analyses of the major ions and silica) and many incomplete analyses, in addition to a very great number of single chloride determinations, have been collected. Such a large quantity of chemical data has made it possible to reduce to a minimum the misleading conclusions that would be derived from a few or a single analysis. Most of the analytical work was done in the following laboratories: the U.S. Geological Survey; the Board of Water Supply, City and County of Honolulu; Public Works Department, 14th Naval District; and the Hawaii State Board of Health. The analyses: were made in the period from about 1900 to 1959 , but most of them were made since about 1940 . 
In this section of the report, where the chemical analyses given are representative of specific types of water, the results listed are modal values, unless polymodal distribution occurs or the number of available analyses is small. If unimodal distribution is lacking but the number of analyses is 10 or more, then the median value is used. Where less than 10 analyses are available, the mean is used, but occasionally a single value must be employed. Values other than the mode are indicated in the tables of analyses.

The mode, or most frequently occurring value in a group of data, is the preferred choice for representative analyses. Use of the mode eliminates the distorting effects of extreme values, which are not uncommon in water analyses because of improper sampling, the collection of unrepresentative samples, and occasional errors in analysis. The mean value reflects the extremes and therefore may not always be reliable. The median gives the middle value above which half the values lie and below which the remaining half lie. The median could justifiably have been the preferred value, but the mode was selected because it is typical of the representative composition. Table 7 indicates the relations between the mode, median, and mean of the major constituents of water in dike compartments in the Koolau Volcanic Series. In the table the differences between values are not large, but for waters having greater concentrations of dissolved solids, significant differences may occur.

TABLE 7.-Comparison of the mode, median, and mean of chemical constituents of water in dike compartments in the Koolau Range

[Constituents in parts per million. Analytical data by U.S. Geol. Survey; Honolulu Board of Water Supply; Hawail State Board of Health; and U.S. Navy]

\begin{tabular}{|c|c|c|c|c|}
\hline Constituent & $\begin{array}{l}\text { Number of } \\
\text { values }\end{array}$ & Mode & Median & Mean \\
\hline 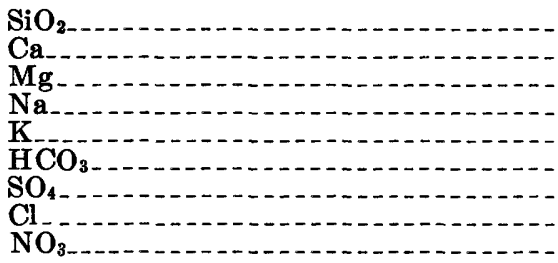 & $\begin{array}{r}19 \\
13 \\
13 \\
11 \\
8 \\
16 \\
13 \\
19 \\
17\end{array}$ & $\begin{aligned} & 15 \\
& 7.0 \\
& 5.0 \\
& 13 \\
& 1.0 \\
&(1) \\
& 3.0 \\
& 16.50\end{aligned}$ & $\begin{aligned} & 15 \\
& 7.2 \\
& 4.6 \\
& 11 \\
& 1.4 \\
& 50 \\
& 3.5 \\
& 16 \\
& \quad .55\end{aligned}$ & $\begin{aligned} 14.6 \\
7.0 \\
4.2 \\
11 . \\
1.3 \\
\text { 51. } 1 \\
3.4 \\
16.62\end{aligned}$ \\
\hline
\end{tabular}

1 Polymodal. Minimum modal value, $39 \mathrm{ppm}$; maximum modal value, $61 \mathrm{ppm}$.

STREAM WATER

The streams of Oahu whose beds are above the regional water table receive their base flow from ground water impounded by dikes, from bank storage, and from perched water bodies. In the Honolulu area the base flows are dominated by dike water, but west of the Kalihi 
Valley bank storage is the principal source. Perched water is of minor importance in both areas. Throughout the island all streams respond quickly to rainfall.

Many chemical analyses have been made of water from streams in the Honolulu area, but only one is known from a stream in the Pearl Harbor area. The streams in Honolulu are dike fed, and the analyses are of a composite chiefly of dike water, water from bank storage, and perhaps a small amount of direct runoff. Table 8 lists an analysis (No. 1) representative of these streams. An analysis was made of a sample collected from Waiawa Stream in the Pearl Harbor area during a dry period when it was fed only from bank storage and perched water. It is similar to the representative analysis of the Honolulu streams. Streams in both the Honolulu and Pearl Harbor areas head in the high rainfall area of the Koolau Range, and during periods when storm runoff provides the largest part of the flow, the quantity of dissolved solids is considerably reduced.

TABLE 8.-Chemical composition of uncontaminated natural water from various sources in southern Oahu

[All values are modal unless otherwise noted. Asterisk indicates mean value. Analytical data by Honolulu Board of Water Supply and U.S. Navy]

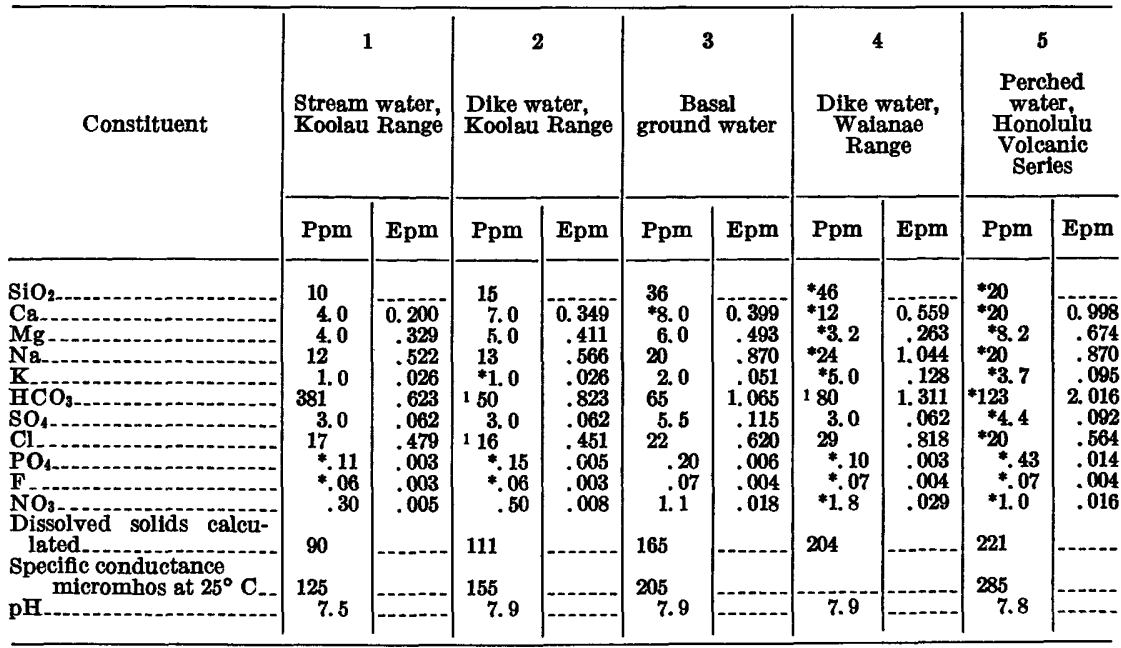

1. Streams fiowing from Koolau Range in Honolulu area. Composite of dike water, bank storage, and direct runoff. Based on analyses by the Honolulu Board of Water Supply.

2. Tunnels penetrating dikes in Koolau Range in Honolulu area. Based on analyses by the Honolulu Board of Water Supply.

3. Wells and shaft on southeast slope of Koolau Range. Based on analyses by the Honolulu Board of Water Supply.

4. Lualualei tunnei, Waianae Range. Based on analyses by Public Works Office, 14th Naval District.

5. Makiki and Booth Springs fiowing from rock of the Honolulu Volcanic Series in the Honolulu area. Based on analyses by the Honolulu Board of Water Supply.

1 Median value. 
DIKE WATER

The statistical data in table 7 indicate the composition of ground water in dike compartments in the Koolau Volcanic Series. The samples for analysis were obtained from tunnels penetrating dikes in the mountains behind Honolulu. The sources of the dissolved constituents in this water are rainfall, the mantle of vegetation and soil, basalt of the Koolau Volcanic Series, and sea spray blown onto the land. The statistical data indicate the composition of ground water percolating into the aquifer in regions of high rainfall (100-150 inches per year) in the Koolau Range. The recharge water in areas having higher rainfall than the Honolulu area is somewhat lower in total dissolved solids. For example, dike water from the Waiahole Tunnel, which is an area having 150-200 inches of rain, has a chloride content of about $12 \mathrm{ppm}$ and a specific conductance of 121 micromhos, as compared with the modal values of $16 \mathrm{ppm}$ and 155 micromhos for dike water in the Honolulu area. The smaller concentration of dissolved constituents in the Waiahole Tunnel water is the result of higher dilution and lower evapotranspiration. On the other hand, water in dike compartments in the Waimanalo area of Oahu at the southeast end of the Koolau Range, where the annual rainfall is 100 inches or less, has a mean chloride content of $18.5 \mathrm{ppm}$. This effect of increasing dissolved solids with decreasing rainfall is even more pronounced in the dike water of the Waianae Range.

Table 8 lists average and modal values of major chemical constituents in water from a tunnel in Lualualei Valley, which penetrates dike compartments in the Waianae Range where the annual rainfall in the area of recharge is no more than 50 inches. The high content of dissolved solids compared with that of dike water in the Koolau Range shows the effect of low dilution (low recharge) and high evapotranspiration rates that are typical of regions of low rainfall.

BASAL WATER IN THE KOOLAU VOLCANIC SERIES

Careful selection of water sources is required in determining a representative analysis of uncontaminated basal water. The fresh basal lens grades through the transition zone into the saline water intruded from the sea, and irrigated fields from which recharge occurs overlie much of the area of its occurrence. In addition, because of the wide extent of the basal water, there are local anomalies in the composition of uncontaminated water, such as those produced by dry climate and changes in the soil and vegetation mantle. Analyses used were those made by the Honolulu Board of Water Supply of samples from Shaft 12 (Halawa Shaft), well 196-1 (Waimano Home), and from several wells outside the irrigated areas. All these sources draw from the upper part of the lens and are probably free of appreciable mixture 
with sea water. Analysis 3 in table 8 probably represents water in about the center of the basal-water region of the Pearl Harbor area outside the irrigated section. Because of the smaller dissolved-solids content of the rain, the lower evapotranspiration rates, and the higher dilution rates, water nearer the mountains contains a slightly smaller quantity of dissolved solids. Toward the shore the reverse is true.

\section{PERCHED WATER IN THE HONOLULU VOLCANIC SERIES}

A composite analysis of water from Makiki and Booth Springs given in table 8 shows the composition of ground water in rocks of the Honolulu Volcanic Series (analysis 5). The springs flow from basalt and pyroclastic deposits in an area receiving about 100 inches of rain per year. Water represented by the analysis differs significantly in many respects from uncontaminated water in basalt of the Koolau Volcanic Series because of the differences in the composition of the rocks of the Koolau and Honolulu Volcanic Series. Minor peculiarities that occur in the composition of the uncontaminated water of the Koolau aquifer in artesian areas 1 and 2 can be attributed to water that percolates through the Honolulu Volcanic Series into the main body of basal water in the basalt of the Koolau Volcanic Series.

Figure 36 is a trilinear diagram illustrating the relationship between the various types of uncontaminated water in southern Oahu. Sea water and rainwater are included for comparison.

\section{SOLUTION FROM THE TERRESTRIAL ENVIROMAEENT}

In water uncontaminated by sea-water intrusion or activity by man, the amount of each constituent derived from the terrestrial environment can be estimated by assuming that the chloride originates only in the rainfall and by calculating the proportion of each constituent associated with the chloride. Chloride is a constituent of some rocks, particularly in the minerals apatite and plagioclase, but it is a negligible quantity in comparison to other constituents. Only a few analyses of Hawaiian rocks list chloride as a constituent. Shepherd, as reported by Correns (1956, p. 187), found a chloride content of 100 ppm in a 1926 basalt flow from Mauna Loa. Analyses, by K. T. Mau ${ }^{2}$ gave chloride values of 150,210 , and $180 \mathrm{ppm}$ for fresh basalt from Kilauea and 150,90, and $120 \mathrm{ppm}$ for aa from the 1935 flow of Mauna Loa. L. T. Bryson (1951, unpublished data, Honolulu Board of Water Supply) reported a chloride content of $30 \mathrm{ppm}$ in cinder of the Honolulu Volcanic Series.

2 Mau, K. T., 1940, A study of the chemical decomposition of rocks at Kilauea: Unpublished manuscript thesis on file with University of Hawail, Honolulu, Hawail. 


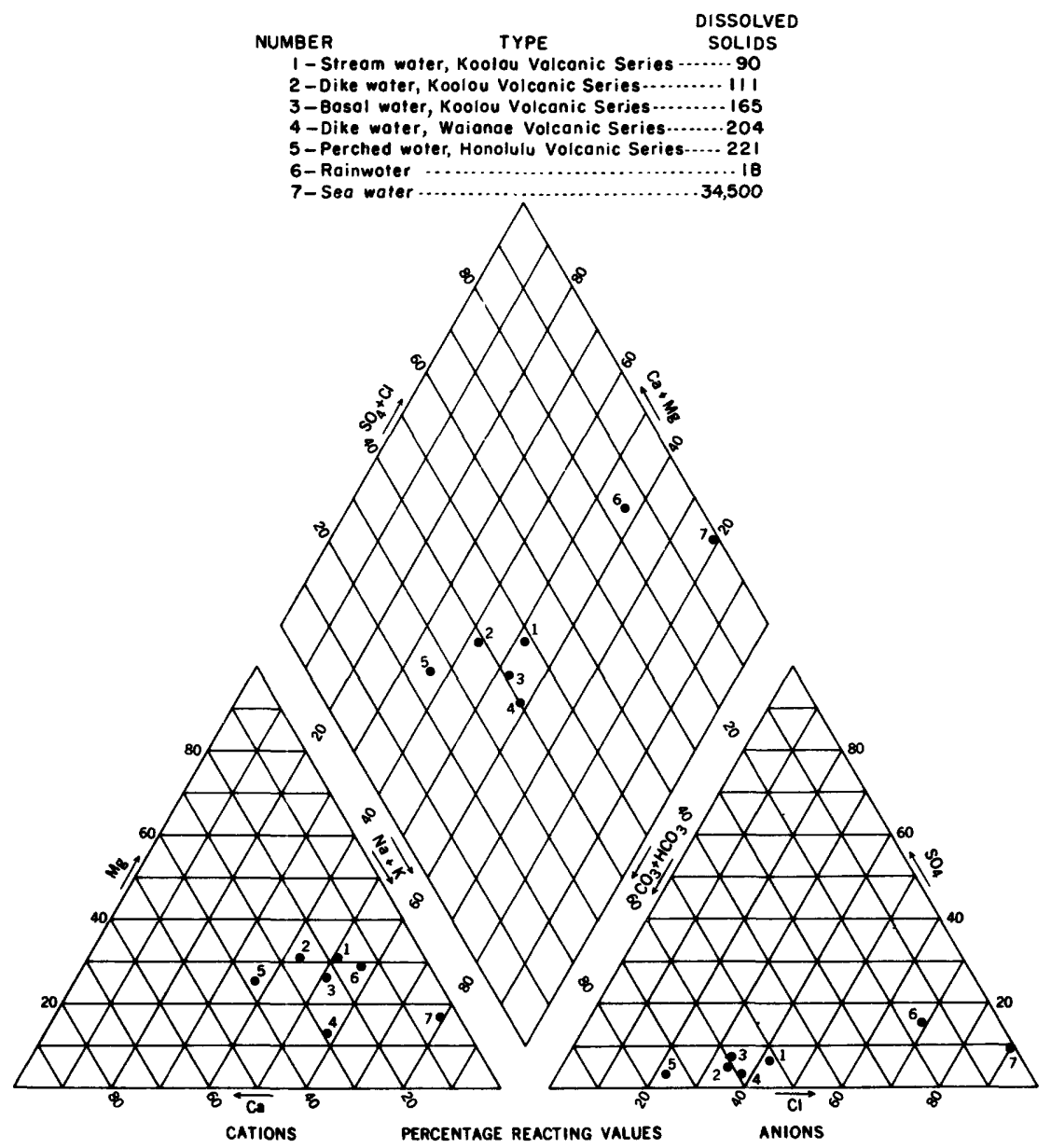

Figdre 36.-Comparison of the chemical compositlons of sea water and ground water, stream water, and rainwater in southern Oahu.

The average chloride content of world-wide basalts, according to Rankama and Sahama $(1950$, p. 756$)$, is about $260 \mathrm{ppm}$. Kuroda and Sandell $(1953$, p. 879$)$ reported that the average basalt and diabase contains $140 \mathrm{ppm}$ of chloride. Thus, basalts in general, including those of southern Oahu, can be expected to contain very little chloride. If the chloride in Oahu rock were easily leached, the great quantity of water moving through the rock would remove all of it by solution in a relatively short time. A simple calculation shows that in a geologically short time (about 100,000 years) all the chloride would be leached from a rock having a chloride content of $100 \mathrm{ppm}$ in an area of 125 square miles and a depth of 1,000 feet if $1 \mathrm{ppm}$ were carried 
away in 300 million gallons of water each day. On the other hand, if the chloride in the rock resisted leaching, then only a minute amount would concentrate in the ground water.

Most of the chloride in basalt of the Koolau Volcanic Series is probably intimately associated with fluoride and phosphate in the mineral apatite, in which the chloride ion can replace the fluoride ion. The concentration of both fluoride and phosphate in ground water, however, is much less than $1 \mathrm{ppm}$, and because the chloride content of apatite is only a fraction of either the fluoride or phosphate contents, an even smaller quantity of it can be expected to dissolve in the ground water. Therefore, the soil and rock may be reasonably ignored as sources of chloride.

Table 9 gives the calculated concentrations of chemical constituents dissolved in streams, dike water, and basal water in contact with basalt of the Koolau Volcanic Series. Sulfate is not included because apparently more sulfate falls with rain than can be accounted for in the water. The deficit of sulfate may be due to reducing conditions in the vegetative mantle or to its use by plants. Nitrate is not included because all nitrate not present in the rain is assumed to be derived from organic processes. Bicarbonate is not listed because it also does not represent material removed from the rock.

Table 9 also indicates the relative mobility of each of the most abundant constituents in the rock and in the water. The relative mobility is a measure of the ease with which the elements go into

TABLE 9.-Calculated quantities of chemical constituents dissolved from basalt of the Koolau Volcanic Series in water from various sources and relative mobility of the most abundant constituents

[Analytical data by Honolulu Board of Water Supply; U.S. Geol. Survey; Hawaii State Board of Health; and U.S. Navy]

\begin{tabular}{|c|c|c|c|c|c|c|}
\hline \multirow{3}{*}{ Constituent } & \multicolumn{6}{|c|}{ Water source } \\
\hline & \multicolumn{2}{|c|}{ Stream } & \multicolumn{2}{|c|}{ Dike compartments } & \multicolumn{2}{|c|}{ Basal aquifer } \\
\hline & Ppm & $\begin{array}{l}\text { Relative } \\
\text { mobilitity }\end{array}$ & Ppm & $\begin{array}{l}\text { Relative } \\
\text { mobility }\end{array}$ & Ppm & $\begin{array}{l}\text { Relative } \\
\text { mobility }\end{array}$ \\
\hline $\begin{array}{l}\mathrm{SiO}_{2} \\
\mathrm{Ca}_{2} \\
\mathrm{Mg} \\
\mathrm{Na} \\
\mathrm{K} \\
\mathrm{Cl} \\
\mathrm{P} \\
\mathrm{PO}\end{array}$ & $\begin{array}{l}10 \\
1.9 \\
1.5 \\
3.2 \\
.40 \\
0.11 \\
.06\end{array}$ & $\begin{array}{r}\text { 8. } 75 \\
\text { 1. } 09 \\
\text { 1. } 22 \\
\text { 5. } 74 \\
\text { 5. } 22 \\
\\
\end{array}$ & $\begin{array}{r}15 \\
5.0 \\
2.7 \\
4.7 \\
.44 \\
.15 \\
.06\end{array}$ & $\begin{array}{l}\text { 0. } 68 \\
\text { 1. } 76 \\
\text { 1. } 34 \\
\text { 5. } 15 \\
\text { 3. } 51 \\
\end{array}$ & $\begin{array}{r}36 \\
5.2 \\
2.8 \\
8.6 \\
1.2 \\
.20 \\
.07\end{array}$ & $\begin{array}{r}0.85 \\
.94 \\
.72 \\
4.87 \\
5.07 \\
\\
\end{array}$ \\
\hline Total & 17. 17 & $\ldots \ldots$ & 27. 84 & 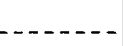 & 54. 07 & 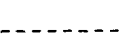 \\
\hline
\end{tabular}


solution and are carried away in the water. It is obtained in the following manner :

$$
\text { Relative mobility }=\frac{\text { percent constituent in water }}{\text { percent constituent in rock }} \text {, }
$$

where the initial percentages of the constituents in the rock and in water are recalculated to 100 percent. The relative mobility as calculated, however, may be more apparent than real because of ion exchange. The calcium and magnesium tend to fill the unsatisfied exchange positions in the weathered rock being continually formed, and the sodium and potassium are forced to stay in solution. Thus, although the calcium and magnesium may dissolve actually more easily than the univalent cations, the tendency of the weathered material to retain the calcium and magnesium results in a comparatively greater concentration of sodium and potassium in solution. This tendency is especially true for the water that percolates along the circuitous route to the basal aquifer. Soils, as shown in table 6, are almost completely free of sodium, potassium, calcium, and magnesium, which suggests that all the bases are highly mobile. The silica is free of exchange effects.

The values given for water in the basal aquifer of the Koolau Volcanic Series (table 9) are generally those for water in the entire aquifer. Approximately $54 \mathrm{ppm}$ of the dissolved constituents in water in the basal aquifer are derived from the basalt by solution. In southern Oahu about $300 \mathrm{mgd}$ is discharged from the basalt aquifers. This amounts to $2,500 \times 10^{6}$ pounds of water in which $135 \times 10^{3}$ pounds of mineral matter are dissolved from the basalt. The density of basalt is about 2.8 , which is equal to nearly 175 pounds per cubic foot. Thus, approximately 770 cubic feet of basalt are dissolved each day in this region.

\section{SEA-WATER INTRUSTON}

Saline water underlying the fresh-water lens in the permeable basalt of the island differs appreciably in chemical composition from the water of the open sea, where it originated. The principal differences are in the concentrations of the cations calcium, magnesium, sodium, and potassium and of the anion sulfate. The differences in cation concentration can be traced to ion-exchange processes; the difference in the concentration of the sulfate anion is probably caused by sulfate reduction. Mast of the other dissolved constituents in the saline water also show deviations in concentration from sea water, but the magnitude of the differences is subordinate to that of the cations and sulfate. The chloride content is not affected by the conditions that cause changes in the other constituents; consequently, the chloride is used as an index for determining variations in quantities among the 
other dissolved constituents and as a measure of the ratio of intruded saline water to fresh recharge water in the transition zone.

Before entering the basaltic rock of the island, sea water must pass first through the layer of sediment and sedimentary rock that lies on the ocean bottom around the island. Near the shore and to a depth of several thousand feet below sea level, the sedimentary rock consists of caprock, and the sediments, of globigerina ooze. The caprock is composed of marine calcareous deposits and terrestrially derived clays high in concentration of calcium and magnesium. The globigerina ooze consists chiefly of minute calcareous skeletons.

The caprock is several miles wide off southern Oahu and extends to a depth of at least 1,200 feet below sea level. According to Hamilton $(1957$, p. 1018) the sea bottom between 1,800 feet and 12,600 feet consists of globigerina ooze containing 34-78 percent calcium carbonate (13.6-31.2 percent calcium) by weight. An analysis of a globigerina ooze taken from a depth of 9,930 feet about 26 miles off Oahu gave a calcium content of 23.9 percent, a magnesium content of 1.6 percent, a sodium content of 1.5 percent, and a potassium content of 0.71 percent (Goldberg and Arrhenius, 1958, p. 170).

As the caprock and associated sea bottom sediments contain much clay, they undoubtedly have a high ion-exchange capacity and could be expected to be saturated chiefly with calcium and magnesium before sea water moves through them. The concentration of sodium in sea water, however, is so great in comparison with calcium and magnesium concentrations that as the sea water passes through the sediments, the ion-exchange positions become saturated with sodium. Thus, the intruding water is enriched in calcium and magnesium and depleted in sodium. Potassium acts similarly to the sodium. The exchange process involves neither a loss nor gain in total equivalents of cations in solution. The exchange can be stated by the generalized equation

$$
(\mathrm{Ca}, \mathrm{Mg}) \text { clay }+2\left(\mathrm{Na}^{+}, \mathrm{K}^{+}\right) \rightleftharpoons 2(\mathrm{Na}, \mathrm{K}) \text { clay }+\left(\mathrm{Ca}^{++}, \mathrm{Mg}^{++}\right) \text {. }
$$

After passing through the sediments into the basalt of the island, the intruded saline water generally no longer undergoes extensive exchange reactions. Although the basalt is not completely without exchange capacity, the magnitude of its capacity is negligible in comparison with that of sea-bottom sediments. A small amount of solution-probably comparable with that taking place in the fresh-water lens-occurs, but the quantity of dissolved constituents added to the intruded water is insignificant in comparison with the dissolved burden it already contains. Cores from test holes and wells drilled deep into the zone of mixture do not show that the rocks are any more affected by the saline water than by the fresh water. 
The smaller quantity of sulfate in intruded saline water in comparison with that in sea water is due to the reduction of sulfate in the sea-bottom sediments by the action of organic matter and anaerobic bacteria. The products of the reaction are commonly bicarbonate and hydrogen sulfide. This chemical transformation can be described by the following general reaction:

$$
\begin{gathered}
\mathrm{RSO}_{4}+2 \mathrm{C}^{\text {Organic }} \rightleftharpoons \mathrm{RS}+2 \mathrm{CO}_{2}, \\
\mathrm{RS}+2 \mathrm{CO}_{2}+2 \mathrm{H}_{2} \mathrm{O} \rightleftharpoons \mathrm{R}\left(\mathrm{HCO}_{3}\right)_{2}+\mathrm{HS},
\end{gathered}
$$

where $R$ represents a cation.

The interaction of hydrogen sulfide with metallic ions can lead to metallic sulfides. Keith and Degens $(1959$, p. 41, 51) showed that the sulfur content of marine muds from the sea bottom of Oahu is more than five times greater than that of fresh-water muds. Marine muds contain 1.5-3.2 percent sulfur compared to 0.3 percent in fresh-water muds. Solution of sulfate from the basalt aquifer is negligible in the fresh-water lens and apparently also in the rock intruded by saline water.

COMPOSITION OF THE INTRUDED WATER AND ITS EFFECT IN THE ZONE OF MIXTURE

In southern Oahu only two chemical analyses have been made of well water whose chloride content (about $17,500 \mathrm{ppm}$ ) approaches that of sea water. Aside from these analyses, our knowledge of the composition of the intruded water must be obtained through analyses of water from the zone of mixture. A sufficient number of analyses of water containing as much as $10,000 \mathrm{ppm}$ of chloride are available to indicate the composition of the saline water below the lens.

The mixing of the intruded saline water with fresh ground water results in a mixture in which only the chloride content can be assumed to be that of a simple sea water-fresh water mixture. If it is assumed that the chloride of sea water is inert to change during the intrusion process and that the chloride content of the intruded water is equal to that of sea water, the chloride content of water in the zone of mixture will vary linearly with the amount of intruded water in the mixture. For chloride concentrations of more than about $500 \mathrm{ppm}$, the chloride contributed by fresh ground water will be small and can be disregarded, and all the chloride can be assumed to have been derived from the intruded water. Similarly, the quantities of calcium, magnesium, sodium, potassium, and sulfate contributed by the fresh water in the zone of mixture are negligible in comparison with that contributed by the intruded water, and at concentrations greater than about 500 ppm, each of these ions can be assumed to have originated with the 
intruded water. By plotting the concentration of the dissolved ions as a function of chloride content, the nature of the intruded water can be deduced, provided that a determinable relationship can be established among the variables. Also, such a relation will indicate whether the mixing is simple or is complicated by ion exchange or other chemical reactions within the aquifer.

Analyses of well-water samples having a wide range of chloride contents are available for areas 2 and 6 in southern Oahu. In area 2 the analyses show a chloride content ranging from $36 \mathrm{ppm}(1.015 \mathrm{epm})$ to $7,430 \mathrm{ppm}(209.95 \mathrm{epm})$, which is equal to about 39 percent of that of sea water. In area 6 chloride contents range from $31 \mathrm{ppm}(0.874 \mathrm{epm})$

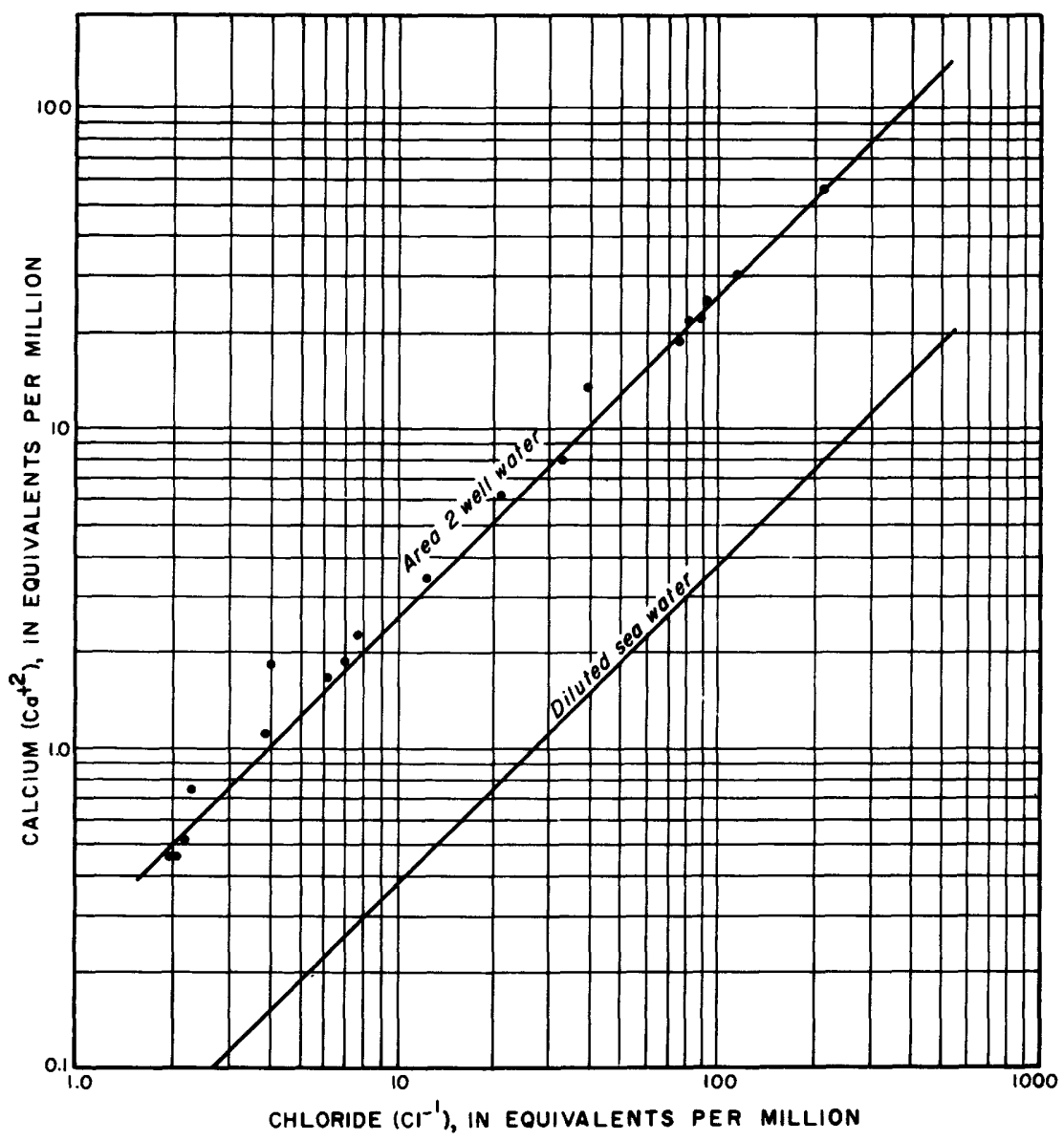

Figdre 37.-Comparison of the calcium content of well water from the basaltic aquifer in area 2 of Honolulu, as a function of chloride content, with that of sea water diluted to the chloride content of the well water. The well water represents a mixture of intruded sea water and fresh water. 
to $17,700 \mathrm{ppm}$ (499.14 epm), which is equal to about 93 percent of that of sea water.

Figures 37-39 compare the variation in equivalents per million of calcium, magnesium, and sodium and potassium with chloride content in mixtures of fresh water and sea water in area 2. The curves indicate that the enrichment of calcium and magnesium in the zone of mixture occurs at the expense of sodium and potassium.

Figure 39 shows that the total cation equivalents in the zone of mixture are very nearly equal to the total in diluted sea water of the same chloride content and, therefore, that neither solution nor precipitation of the cations is appreciable within the aquifer. The graphs also indicate that the zone of mixture is a simple mixture of the fresh and intruded waters.

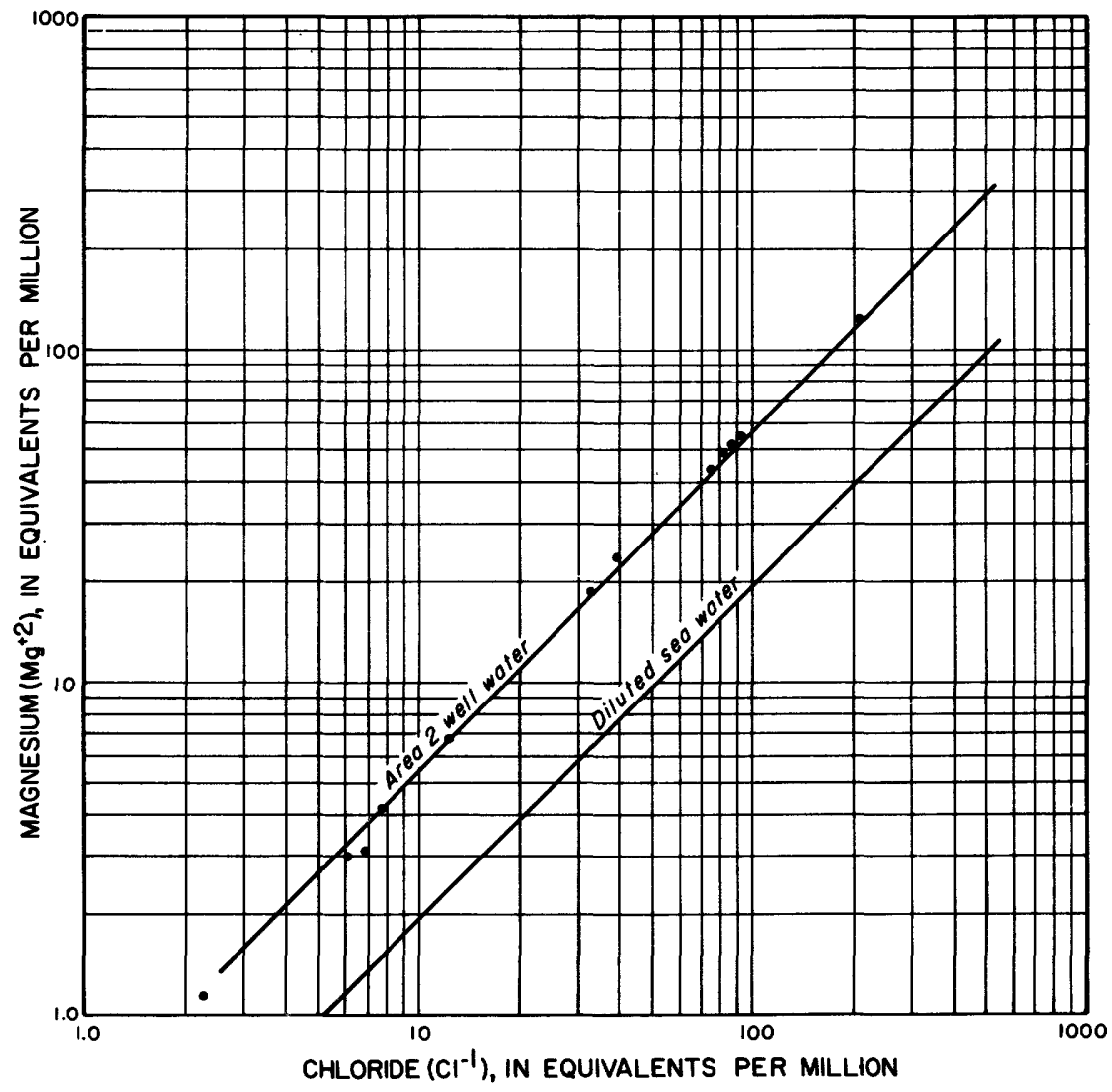

Figdre 38.-Comparison of the magnesium content of well water from the basaltic aquifer in area 2 of Honolulu, as a function of chloride content, with that ot sea water diluted to the chloride content of the well water. The well water represents a mixture of intruded sea water and fresh water. 


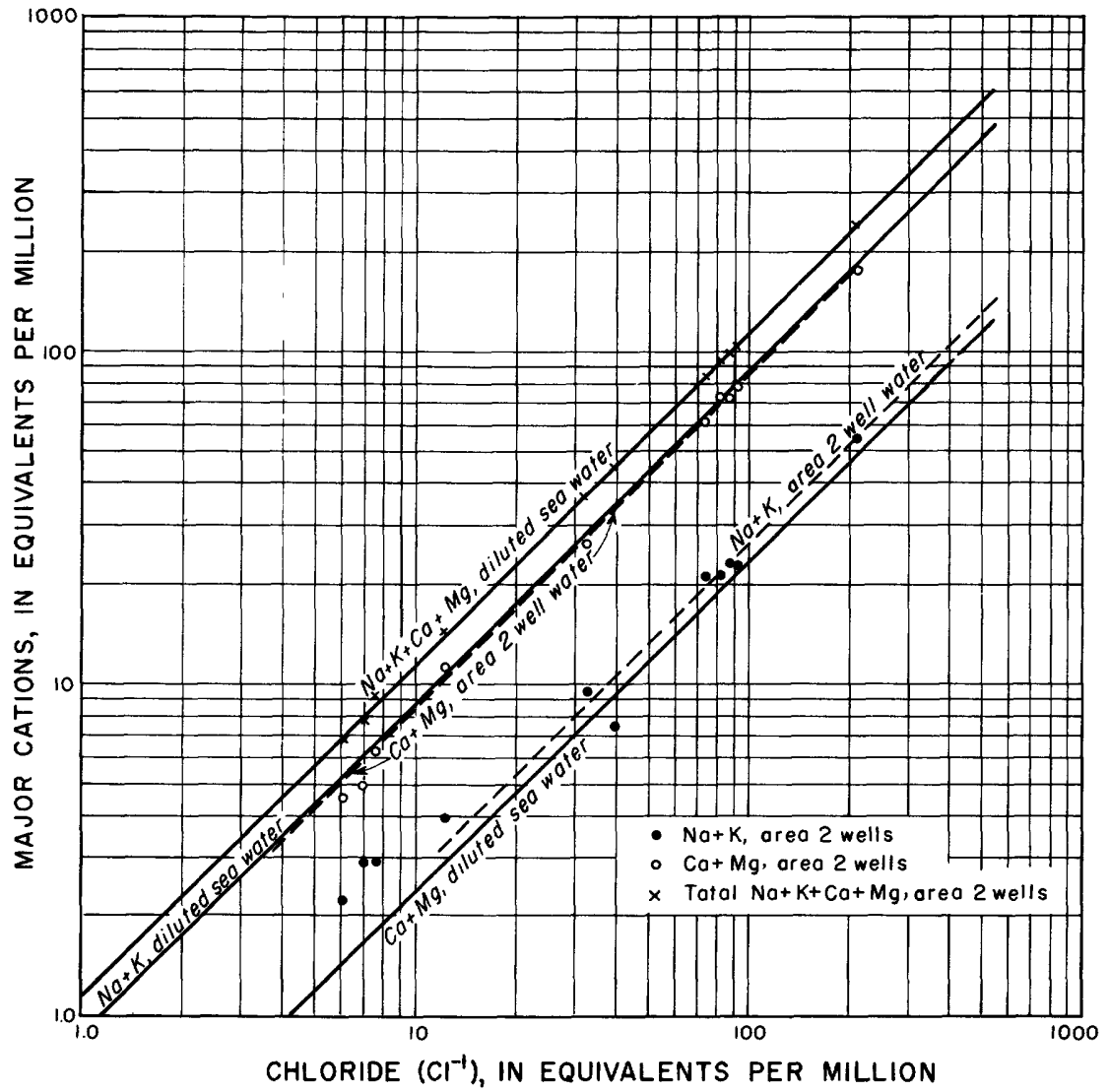

FIGURE 39.-Comparison of the total major cation content of well water from the basaltic aquifer in area 2 of Honolulu, as a function of chloride content, with that of sea water diluted to the chloride content of the well water. The well water represents a mixture of intruded sea water and fresh water.

Figure 40 indicates the variation of sulfate with respect to chloride in area 2. It shows that the intruded water is lower in sulfate than sea water and that neither gain nor loss of sulfate takes place within the zone of mixture.

The highest chloride content in area 2 indicates that the water contains only about 40 percent intruded saline water, but the linear relationship between the various dissolved constituents and chloride indicates that the graph for the chloride content extrapolates to the chloride content of sea water $(535.3 \mathrm{epm})$. The cation and the sulfate concentrations of the saline water underlying the lens, as determined by this extrapolation, and the manner in which the water differs from sea water are indicated in table 10. 
TABLE 10.-Comparison of major cation and sulfate concentrations of saline water intruded into the basaltic aquifer with those of sea water

[Analytical data by U.S. Geol. Survey]

\begin{tabular}{|c|c|c|c|c|}
\hline \multirow{2}{*}{ Constituent } & \multirow{2}{*}{$\begin{array}{l}\text { Intruded } \\
\text { saline water } \\
\text { (epm) }\end{array}$} & \multirow{2}{*}{$\begin{array}{c}\text { Sea water } \\
\text { (epm) }\end{array}$} & \multicolumn{2}{|c|}{ Difference } \\
\hline & & & Epm & Ppm \\
\hline $\begin{array}{l}\text { Calcium } \\
\text { Magnesium } \\
\text { Sodium } \\
\text { Potassium } \\
\text { Sulfate. }\end{array}$ & $\begin{array}{r}145 \\
305 \\
131 \\
5 . \\
43\end{array}$ & $\begin{array}{c}20 \\
105 \\
459 \\
9.7 \\
55\end{array}$ & $\begin{array}{l}+125 \\
+200 \\
-328 \\
-4.7 \\
-12\end{array}$ & $\begin{array}{r}+2,505 \\
+2,433 \\
-7,540 \\
-183 \\
-577\end{array}$ \\
\hline
\end{tabular}

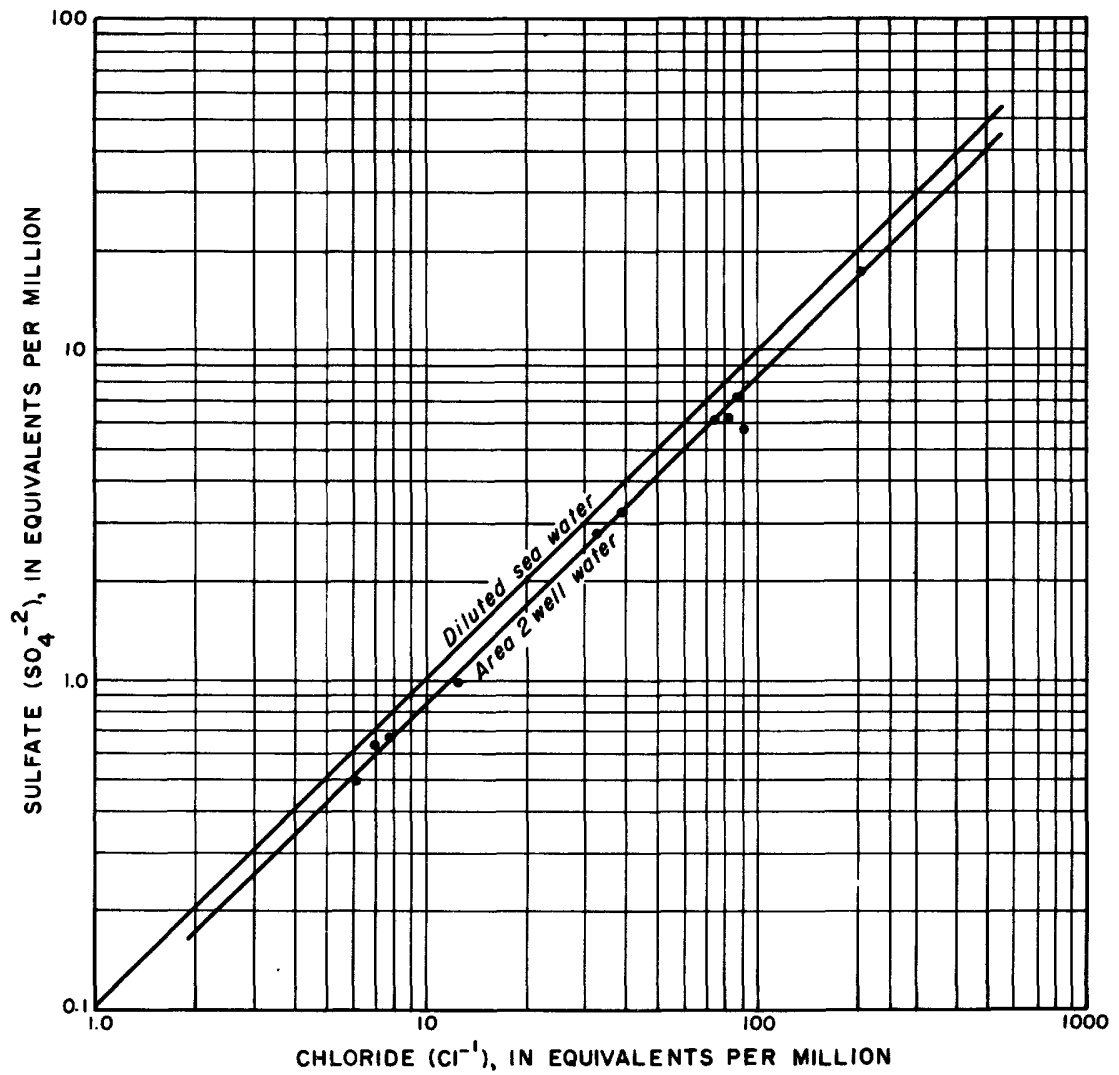

Figure 40.-Comparison of the sulfate content of well water from the basaltic aquifer in area 2 of Honolulu, as a function of chloride content, with that of sea water diluted to the chloride content of the well water. The well water represents a mixture of intruded sea water and fresh water. 


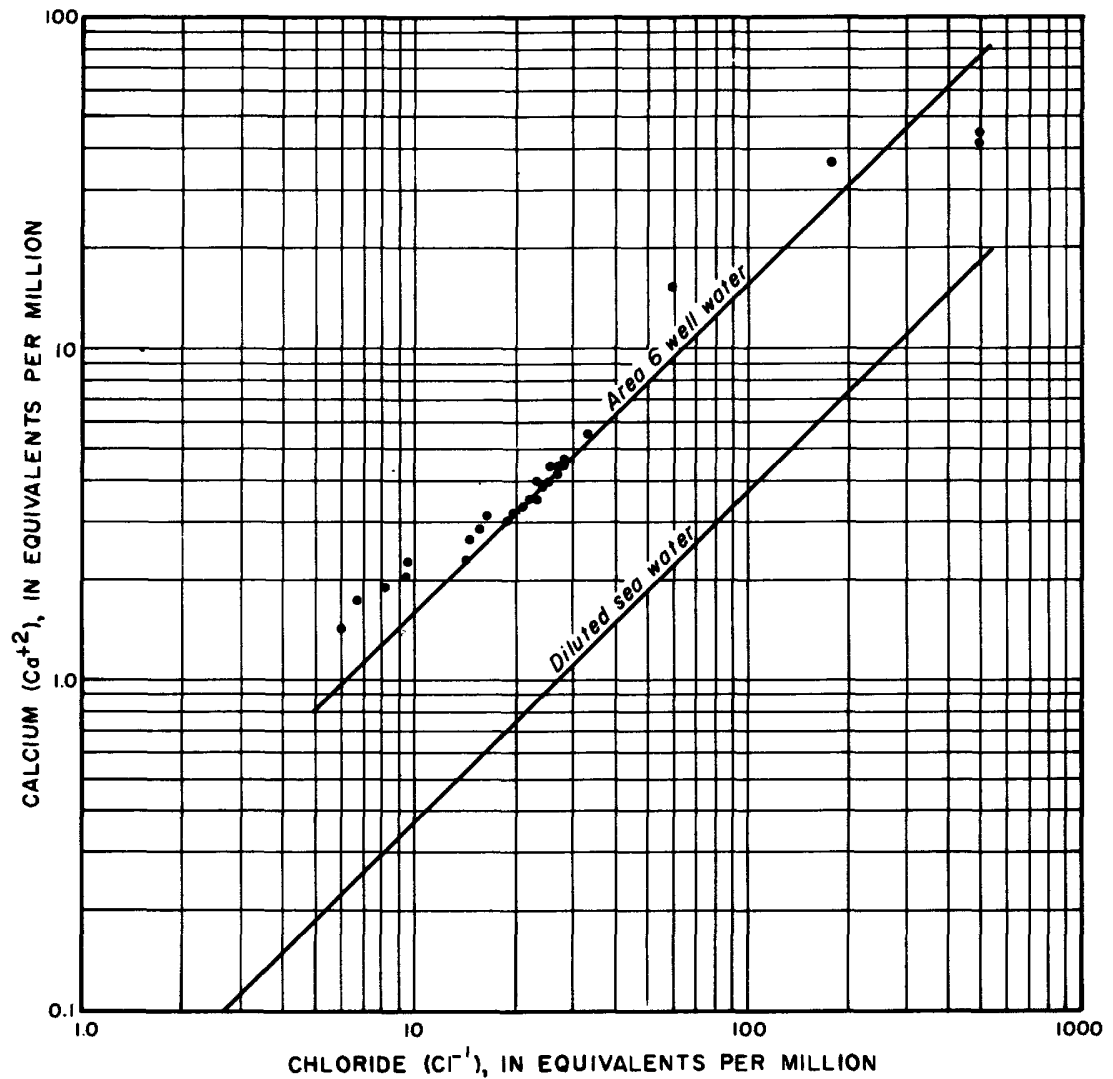

Figdre 41.-Comparison of the calcium content of well water from the basaltic aquifer in area 6, Pearl Harbor area, as a function of chloride content, with that of sea water diluted to the chloride content of the well water.

Examples of relationships in area 6 are given in figures 41-43. In this area water in test hole $\mathbf{T}-67$ has the highest chloride content. Test hole T-67 was drilled through the fresh-water lens to a depth of 1,300 feet below sea level in an attempt to reach undiluted intruded saline water.

The test hole is in an artesian area where the average head is about 20 feet above sea level and where, under static conditions of the Ghyben-Herzberg ratio, the interface between fresh and sea water should be at about 800 feet below sea level. However, the chloridedepth curve in figure 16 shows that the chloride content of the water at 800 feet below sea level was only about $8,000 \mathrm{ppm}$. The highest chloride concentration was $17,700 \mathrm{ppm}$ near the bottom of the hole, and sea water has a chloride content of $18,980 \mathrm{ppm}$. During drilling of the hole many samples of water were taken for chloride and specific 


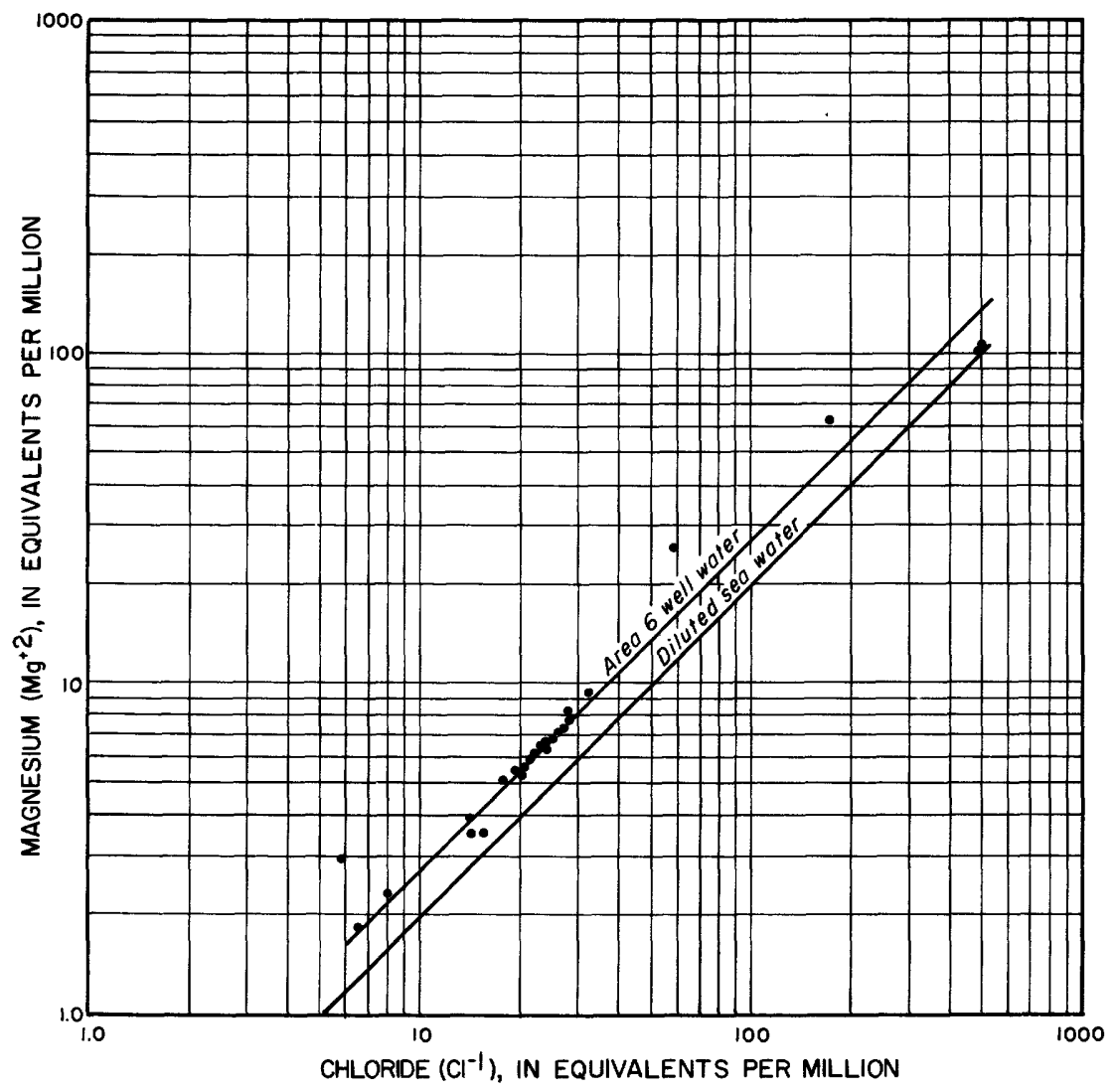

F'igURa 42.-Comparison of the magnesium content of well water from the basaltic aquifer in area 6, Pearl Harbor area, as a function of chloride content, with that of sea water diluted to the chloride content of the well water.

conductivity determinations, and after the completion of drilling, samples for analyses were taken at depths of 388 feet, 740 feet, 1,140 feet, and 1,300 feet below sea level. The samples were obtained by sealing off short sections of the well at various depths, thereby permitting free artesian flow or pumping from the selected depth only.

Table 11 gives the analyses of water samples from various depths in test hole $\mathbf{T}-67$. The hypothetical compositions of sea water diluted to the chloride content of the well water and the difference between the two sets of values are also included. The composition of diluted sea water was determined on the basis of sea-water composition reported by Sverdrup and others $(1946$, p. 176). It should be noted that the calcium and the magnesium contents of the well water do not vary as uniformly with chloride content as they do in well water of area 2. This deviation from linearity is probably due to local 


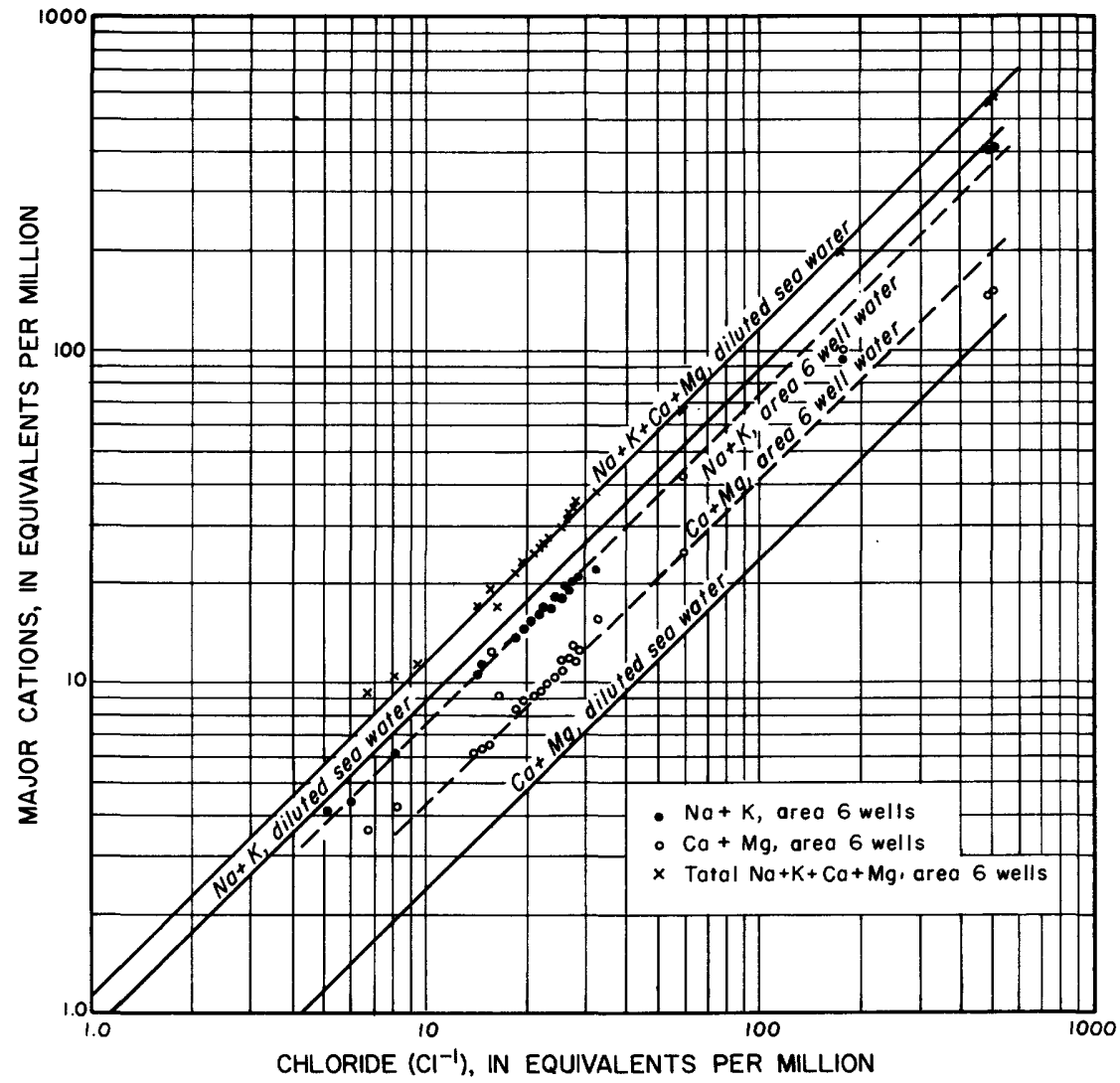

Figure 43.-Comparison of the major cation content of well water from the basaltic aquifer of area 6, Pearl Harbor area, with that of sea water diluted to the chloride content of the well water.

ion exchange in weathered basalt near the test hole. The character of the cuttings produced during drilling suggests that several weathered zones occur in the lower part of the hole. The small differences betwen the cation content of the well water and that of sea water diluted to the same chloride content indicate that chemical reactions other than ion exchange were not responsible for the deviations.

The changes in composition in the zone of mixture are illustrated by figures $41-43$, which are graphs of analyses of samples of water from several wells other than T-67. As shown for water from area 2, the graphs show that both calcium and magnesium are in excess and are matched by an equivalent deficiency in sodium and potassium. The loss of sulfate in water from area 6 is not so marked as it is in that from area 2. The sulfate content in water from area 6 is influenced by an additional sulfate burden contributed by return irrigation 
TABLE 11.-Comparison of dissolved constituents in water from depths of 388,740, 1,140, and 1,300 feet below sea level in test hole T-67 with those in sea water

[Concentrations are given in parts per million. Sea-water concentrations are for sea water diluted to the same chloride concentrations as those of the test-hole water; they were determmed on the basis of ratios calculated from sea-water composition given by Sverdrup and others (i946). Tr, trace.]

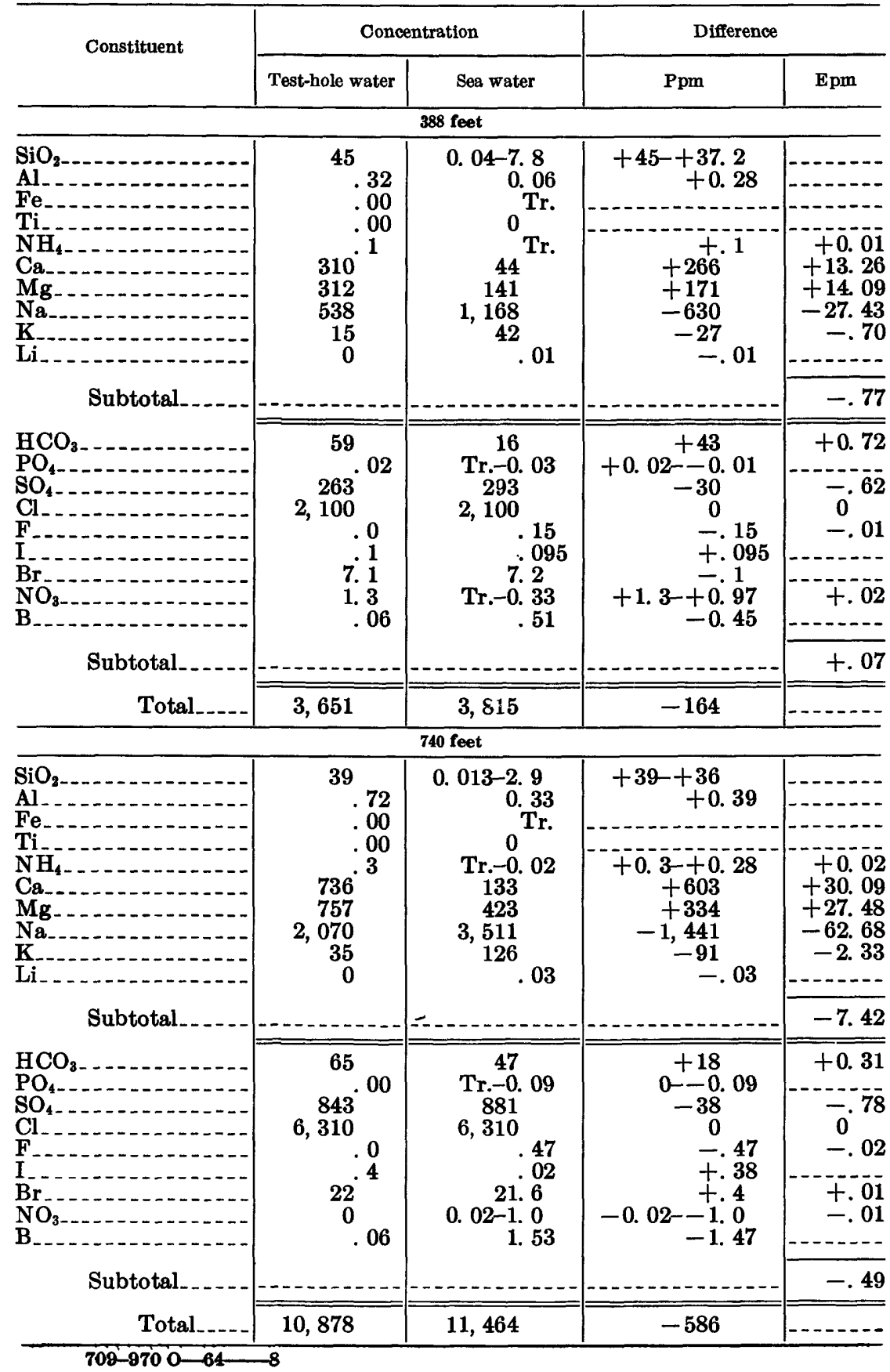


TABLE 11.-Comparison of dissolved constituents $2 n$ water from depths of 388,740 , 1,140 , and 1,300 feet below sea level in test hole $T-67$ with those in sea water-Con.

[Concentrations are given in parts per million. Sea-water concentrations are for sea water diluted to the same chloride concentrations as those of the test-hole water; they were determined on the basis of ratios calculated from sea-water composition given by Sverdrup and others (1946). Tr, trace.]

\begin{tabular}{|c|c|c|c|c|}
\hline & \multicolumn{2}{|c|}{ Concentration } & \multicolumn{2}{|l|}{ Difference } \\
\hline & Test-hole water & Sea water & Ppm & Epm \\
\hline \multicolumn{5}{|c|}{1,140 feet } \\
\hline 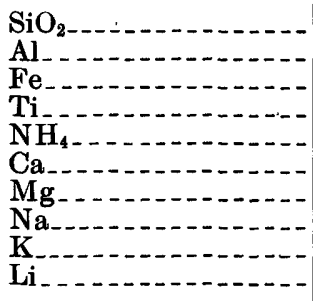 & \multirow[t]{2}{*}{$\begin{array}{r}24 \\
1.0 \\
.00 \\
.02 \\
862 \\
.3 \\
270 \\
110 \\
175 \\
0\end{array}$} & \multirow[t]{2}{*}{$\begin{array}{c}0.04-8.0 \\
0.47 \\
\operatorname{Tr}-0.02 \\
0 \\
\operatorname{Tr}-0.05 \\
373 \\
1,186 \\
9,849 \\
354 \\
.03\end{array}$} & \multirow[t]{2}{*}{$\begin{array}{r}+24-16 \\
+0.53 \\
0--0.02 \\
+.02 \\
+0.3-+0.25 \\
+489 \\
+84 \\
-739 \\
-179 \\
-.03\end{array}$} & $\begin{array}{r}+0.02 \\
+24.40 \\
+6.89 \\
-32.13 \\
-4.58\end{array}$ \\
\hline Sub & & & & -5.40 \\
\hline $\begin{array}{l}\mathrm{HCO}_{3} \\
\mathrm{PO}_{4} \\
\mathrm{SO}_{4} \\
\mathrm{Cl}_{4}\end{array}$ & \multirow[t]{2}{*}{$\begin{array}{rl}2,410^{84} & \\
17,700 & \\
.0 & 00 \\
63 & .4 \\
0.51 & \end{array}$} & \multirow[t]{2}{*}{$\begin{array}{c}131 \\
\operatorname{Tr}-0.3 \\
2,470 \\
17,700 \\
1.3 \\
61.05 \\
\begin{array}{c}61 \\
05-3.0 \\
4.3\end{array}\end{array}$} & \multirow[t]{2}{*}{$\begin{array}{c}-47 \\
0--0.3 \\
-60 \\
0 \\
-1.3 \\
+.35 \\
+2 \\
-0.05--3.0 \\
-3.79\end{array}$} & $\begin{array}{r}-0.76 \\
-1.25 \\
0 \\
-.07 \\
+.03 \\
-.03 \\
\end{array}$ \\
\hline Subtotal & & & & -2.08 \\
\hline Total. & 31,700 & 32,157 & -457 & $----n$ \\
\hline \multicolumn{5}{|c|}{1,300 feet } \\
\hline 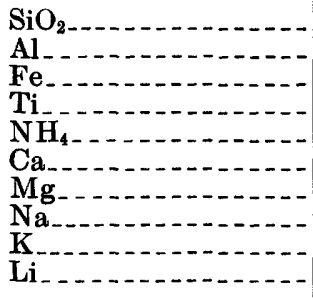 & \multirow[t]{2}{*}{$\begin{array}{r}32.98 \\
.00 \\
.02 \\
.0 \\
906 \\
320 \\
110 \\
171 \\
.0\end{array}$} & \multirow[t]{2}{*}{$\begin{array}{c}0.04-7.9 \\
0.46 \\
\operatorname{Tr}-0.02 \\
0 \\
\operatorname{Tr}-0.05 \\
369 \\
1,173 \\
9,737 \\
350 \\
.03\end{array}$} & \multirow[t]{2}{*}{$\begin{array}{c}+32-+24 \\
+0.52 \\
0--0.02 \\
+0.02 \\
0--0.05 \\
+537 \\
+147 \\
-627 \\
-179 \\
-.03\end{array}$} & $\begin{array}{r}- \\
-26.81 \\
+12.11 \\
-27.29 \\
-4.59\end{array}$ \\
\hline Subt & & & & +7.04 \\
\hline $\begin{array}{l}\mathrm{H}^{\mathrm{H}^{2} \mathrm{O}_{3}} \\
\mathrm{PO}_{4} \\
\mathrm{SO}_{4} \\
\mathrm{CO}_{4} \\
\mathrm{~F} \\
\mathrm{~F}\end{array}$ & \multirow[t]{2}{*}{$\begin{array}{c}106 \\
17,380^{.04} \\
{ }^{2,00} .6 \\
{ }^{63} . \\
.46\end{array}$} & \multirow[t]{2}{*}{$\begin{array}{c}129 \\
\operatorname{Tr}-0.3 \\
2,442 \\
17,500 \\
1.3 \\
.05 \\
60 \\
0.05-3.0 \\
4.3\end{array}$} & \multirow[t]{2}{*}{$\begin{array}{c}-23 \\
+0.04-0.26 \\
-62 \\
0 \\
-.7 \\
+.25 \\
+3 \\
-0.05-3.0 \\
-0.04\end{array}$} & $\begin{array}{r}-0.37 \\
-1.29 \\
0.03 \\
-.03 \\
\hdashline .04 \\
-.03 \\
\hdashline-0\end{array}$ \\
\hline Subtotal__.... & & & & -1.68 \\
\hline Total_..... & 31,590 & 31,792 & -202 & $-\ldots$ \\
\hline
\end{tabular}


water. Irrigated sugarcane is grown extensively in area 6, but no irrigation is practiced in area 2. The sugarcane is heavily fertilized with sulfate salts, which are leached by the heavy application of irrigation water.

VARTATTON IN CONTENT OF ELEMENTS OF LOW CONCENTRATION

Intruded saline water and sea water also have differences in concentration of dissolved constituents other than the alkalis, alkaline earths and sulfate. The largest of these differences occurs in concentrations of silica and bicarbonate, and several other elements vary significantly. These differences can be seen by comparing the water near the bottom of the test hole T-67 with sea water of comparable chloride content (table 11).

The greater amount of silica in the intruded water compared with that in sea water is due to solution, probably both in the sea-bottom sediments and in the basalts of the island, and to enrichment of deep sea water by the solution of siliceous skeletons of organisms. The very close correspondence between the amount of dissolved silica in the intruded water and in fresh basal ground water suggests that this amount (about $35 \mathrm{ppm}$ ) represents the equilibrium value for dissolved silica in the basalt environment of the Koolau Volcanic Series. This suggestion is supported by Krauskopf (1956, p. 1-26), who found that the solution of silica at equilibrium in the sea wateramorphous silica system at $22^{\circ}-27^{\circ} \mathrm{C}$ is nearly the same as it is in the distilled water-amorphous silica system at $25^{\circ} \mathrm{C}$ (115-120 ppm of $\mathrm{SiO}_{2}$ and $102 \mathrm{ppm}$ of $\mathrm{SiO}_{2}$, respectively). About 4 months are required to reach equilibrium (White and others, 1956, p. 27-59). The temperature of the ground water of southern Oahu ranges generally from $20^{\circ}$ to $25^{\circ} \mathrm{C}$, and the normal residence time of water in basalt probably is much longer than 4 months. Thus a meaningful parallel can be drawn between the intruded saline water-fresh water system of southern Oahu and laboratory experiments.

The loss of bicarbonate in the intruded water seems to be anomalous, because the tendency would be toward a higher concentration in intruded water than in sea water because of sulfate reduction. The reason for the decrease probably involves the decrease of pressure on the deep water as it moves upward in the well. The reduction in pressure would permit free carbon dioxide to escape and would therefore cause the equilibrium in the system

$$
\mathrm{H}_{2} \mathrm{O}+\mathrm{CO}_{2} \rightleftarrows \mathrm{H}_{2} \mathrm{CO}_{3} \rightleftarrows \mathrm{HCO}_{3}^{-}+\mathrm{H}^{+} \rightleftarrows \mathrm{CO}_{3}^{-2}+2 \mathrm{H}^{+}
$$

to shift to the left and to precipitate calcium carbonate.

The excess of ammonium in the intruded water is probably due to reducing conditions in the sea bottom sediments. 
The deficiency of fluoride in the intruded water may be caused by its fixation in the authigenic minerals, such as illite, on the sea floor.

The relatively high concentration of iodide in the intruded water as compared to that in sea water is due to a pickup of iodide from sea-bottom sediments. Iodine is an important trace-element nutrient for certain marine-life forms, which accumulate as organic debris on the sea floor. Vinogradov and Dzens-Litovsky (in White, 1957, p. 1,668 ) stated that fine-grained carbonaceous ocean sediments are very rich in iodine.

The nearly equal bromide content of the two waters suggests that the bromide content, like the chloride content, of the sea water is unaffected by the environment through which it moves.

The total lack of nitrate in the intruded water is probably the result of reducing conditions in the sea-floor sediments.

The deficiency of boron may be the result of the formation of relatively insoluble calcium borates (White, 1957, p. 1671). Keith and Degens $(1959$, p. 45) pointed out that marine muds from Oahu have a consistently higher boron content than fresh-water muds. This difference suggests that boron is lost from sea water before it passes into the rocks of the island.

The deficiency of lithium in the intruded saline water as compared with that in sea water is due to the same conditions that affect boron (Keith and Degens, 1959, p. 46).

EFFECT OF IRRIGATION WATER ON THE CHEMISTRY OF BASAL GROUND WATER

A large part of the irrigation water percolates into the basal aquifer from irrigated fields. During application, the water undergoes changes in chemical composition and, in effect, becomes a source of contamination in the basal water. The magnitude of contamination, however, is much less than that caused by the intruded saline water and has not proved detrimental to the quality of the basal water for domestic, agricultural, or industrial uses. On the other hand, the changes in the chemistry of the basal water as a result of the contamination are determinable, and the character of the changes provides qualitative proof that a large volume of irrigation water moves into the basal aquifer.

Water used for irrigation is pumped from the basal aquifer at shafts and drilled wells in the Pearl Harbor area and at springs on the shore of Pearl Harbor; it is transported also to southern Oahu through the Waiahole Tunnel system from streams of windward Oahu and dike compartments in the Koolau Range. The factors causing chemical changes in the water during irrigation are chiefly evapotranspiration, contact with soluble fertilizer salts, reaction in the 
mantle of soil and with vegetation, and, to a small degree, exposure to the atmosphere. The quantities and proportions of each of the major constituents are probably affected, but the changes in nitrate, sulfate, silica, and bicarbonate are the most readily explained. These constituents are not affected greatly by adsorption in the soil, and their changes in concentration are easily recognized. An increase in concentration that takes place in each of them is commonly measurable in the basal water that mixes with return irrigation water. Chloride also is unaffected by adsorptive reactions, but when it is introduced by the intrusion of saline water, the increase in chloride is commonly so great that it masks any changes in concentration that are caused by irrigation water. The cations are subject to ion-exchange reactions and are therefore poor indices of changes caused by irrigation water.

Nitrate is especially well suited as an index because its concentration in uncontaminated waters is well known and its occurrence in intruded saline water is negligible. Silica is also a good index because its background concentration is known, but the difference between its concentrations in uncontaminated water and in intruded saline water is negligible. Corrections must be made for the amount of sulfate and bicarbonate, respectively, contributed by intruded saline water because both sulfate and bicarbonate concentrations vary with chloride concentration. However, the increases in quantities of sulfate and bicarbonate resulting solely from irrigation are large and easily measured, and they can also be used effectively as reliable indicators of chemical changes.

\section{CONTAMINATION FROM FERTILIZERS}

Fertilizer salts applied to cane fields account for all the increase in nitrate and sulfate concentrations beyond those caused by evapotranspiration. Part of the increase in bicarbonate may also result from fertilizers. Only an insignificant part of the silica increase can be attributed to fertilizers.

Fortilizing is necessary to the profitable growing of sugarcane, and it is practiced on a large scale in southern Oahu. The chief nutrients applied are nitrogen, phosphorus, and potassium. As much as 300 pounds of nitrogen, 200 pounds of phosphorus, and 350 pounds of potassium per acre per crop (about 2 years of growth) are considered essential to a healthy crop. Pineapple, which is grown over much of the higher parts of the Pearl Harbor area, is also fertilized heavily, and although pineapple fields are generally not irrigated, a part of the fertilizer salts probably move to the aquifer in percolating rainwater.

Nitrogen is applied on sugarcane fields principally as aqua ammonia, a solution of water and ammonium that contains approximately 
20 percent nitrogen. A second important carrier is ammonium sulfate, $\left(\mathrm{NH}_{4}\right)_{2} \mathrm{SO}_{4}$. Before 1953 most nitrogen was distributed in the sulfate form, but since then the trend has been toward the use of water-ammonium solution. Ammophos, an ammonium phosphate compound containing generally 11 percent nitrogen and 21 percent phosphorus and urea, $\mathrm{CO}\left(\mathrm{NH}_{2}\right)_{2}$, are also used to some extent. Urea and ammonium sulfate are used ordinarily on pineapple fields.

Nitrogen fertilizer applied as ammonia $\left(\mathrm{NH}_{3}\right)$ or the ammonium ion $\left(\mathrm{NH}_{4}{ }^{+1}\right)$ must be converted to nitrate $\left(\mathrm{NO}_{3}{ }^{-1}\right)$ before it can be utilized by plants. The generalized equation for this change is

$$
\begin{gathered}
\text { Bacteria } \\
\mathrm{NH}_{4}^{+1} \rightleftarrows \mathrm{NO}_{2}^{-1} \rightleftarrows \mathrm{NO}_{3}{ }^{-1},
\end{gathered}
$$

in which the conversion is caused by nitrifying bacteria. A fraction of the ammonium ion probably escapes conversion and is either fixed or adsorbed in the soil complex. Agriculturalists have estimated that only 50 percent of the nitrogen in fertilizers is consumed by the sugarcane (Ayres, 1955, p. 69). The remainder, except for the unconverted ammonium, is eventually leached by percolating water and carried to the water table. Its presence in basal water is apparent, because the natural background concentration of nitrate is about $1 \mathrm{ppm}$ whereas many times this concentration is common in the ground water in the irrigated areas.

Although sulfur is esential to plant growth, it is added to croplands generally only as an incidental component of commercial fertilizerfor example, as sulfate in ammonium and potassium sulfate. Large quantities of sulfur (as sulfate) are added to cropped areas each year. For example, every pound of nitrogen applied as ammonium sulfate carries with it 3.45 pounds of sulfate. Some of the sulfur is consumed by plants-about $10-40$ pounds of sulfur, equivalent to $30^{-}-120$ pounds of sulfate per acre (Jordan and Reisenauer, 1957, p. 107) - but it represents only a small part of the total applied. The remainder is eventually carried in solution into the ground-water body, where it is measured as the excess concentration after corrections are made for the natural concentration in uncontaminated water and for the part brought in by intruded saline water.

Because of the large amounts of phosphate and potassium fertilizers applied to fields each year, these constituents would seem to be good indicators of contamination, particularly because they occur in very low concentrations in uncontaminated water. However, neither constituent is a reliable indicator. The phosphate is fixed quickly in most Hawaiian soils, probably as insoluble iron, aluminum, and calcium phosphates, and none moves beyond the soil profile. No evidence of 
phosphate enrichment has been found in any water of southern Oahu. Potassium is subject to ion-exchange reactions, and its unconsumed fraction tends to remain in the soil layer.

\section{CONTAMINATION FROM REACTION IN THE SOIL PROFILE}

The occurrence of silica in basal water of irrigated areas in amounts considerably greater than that in uncontaminated ground water and in intruded saline water strongly suggests that the increase is related to agricultural activity. A reasonable explanation for the increase, besides that due to evapotranspiration, is the reactivity in the soil profile. Over muck of the cultivated areas, humic latosols are the principal soil types. The latosols have a kaolinite base and represent an intermediate stage of laterization that results from relatively low rainfall ( 60 inches per year or less). However, the application of irrigation water on these soils is equivalent to about 120 inches of rain per year, which when added to the normal rainfall gives a total of about 150 inches per year. In regions of high rainfall (more than 60 inches per year) laterization is comparatively rapid. The application of large quantities of irrigation water to fields in normally dry areas simulates high rainfall conditions, which can be expected to accelerate the laterization process. The silica is mobilized during laterization and moves from the soil to the basal water body.

Bicarbonate also is increased because of reaction occurring in the soil and vegetative mantle. Bicarbonate is one product of the aerobic decomposition of organic matter formed when water is present. A small amount of bicarbonate may also form from the absorption of carbon dioxide from the atmosphere. During irrigation the water is again in contact with the atmosphere and again moves through the surface mantle; these are the main areas of bicarbonate uptake.

\section{CHANGES IN BASAL WATER}

Data in table 12 indicate the changes that take place in the composition of basal water as a result of its mixing with return irrigation water. The table lists sources of water samples collected at locations both within and remote from irrigated areas and representative concentrations of uncontaminated basal water in basalt of the Koolau Volcanic Series, as given in table 8. The column on the far right in each table gives, for each source, the ratio of the constituent to that in the representative uncontaminated basal water in order to indicate the magnitude of the differences caused by return irrigation water. Figure 44 shows graphically the increase of nitrate, sulfate, and silica in water in irrigated areas as compared with that in nonirrigated areas. 
TABLE 12.-Representative concentrations of silica, bicarbonate, sulfate, and nitrate in water from various sources in southern Oahu

[Analytical data by Honolulu Board of Water Supply, U.S. Geol. Survey, Hawaii State Board of Health, and U.S. Navy. Modal values given except where otherwise indicated. Analyses are of water from basalt aquifer, Koolau Volcanic Series, except for water from area 11, which is from basalt aquifer, Waianao Volcanic Series; representative uncontaminated basal water is from basalt aquifer, Koolau Volcanic Series. Ratio: constituent concentration in sample to concentration in uncontaminated water]

\begin{tabular}{|c|c|c|c|c|c|c|c|c|c|c|c|c|}
\hline \multirow[b]{2}{*}{ Source } & \multicolumn{3}{|c|}{ Silica $\left(\mathrm{SiO}_{2}\right)$} & \multicolumn{3}{|c|}{$\begin{array}{c}\text { Bicarbonate } \\
\left(\mathrm{HCO}_{3}\right)\end{array}$} & \multicolumn{3}{|c|}{ Sulfate $\left(\mathrm{SO}_{4}\right)$} & \multicolumn{3}{|c|}{ Nitrate $\left(\mathrm{NO}_{3}\right)$} \\
\hline & 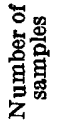 & 层 & 急 & 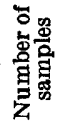 & 层 & 营 & 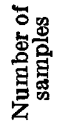 & 萠 & 焉 & 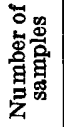 & 层 & 害 \\
\hline $\begin{array}{l}\text { Area } 1 \text { wells } \\
2 \text { wells } \\
3 \text { wells } \\
4 \text { wells and shafts } \\
5 \text { well } 1-B \\
\text { shaft } 7 \\
6 \text { shaft 12- } \\
\text { well } 201 \\
\text { shaft } 3 \\
\text { wells } 257,259,263\end{array}$ & $\begin{array}{r}55 \\
72 \\
\mathbf{4 1} \\
\mathbf{4 7} \\
10 \\
22 \\
15 \\
27 \\
2 \\
\mathbf{3}\end{array}$ & $\begin{array}{r}35 \\
36 \\
33 \\
35 \\
236 \\
338 \\
33 \\
40 \\
43 \\
264 \\
262\end{array}$ & $\begin{array}{r}0.97 \\
1.00 \\
.92 \\
.97 \\
1.00 \\
1.06 \\
1.11 \\
1.20 \\
1.78 \\
1.72\end{array}$ & $\begin{array}{r}37 \\
24 \\
23 \\
33 \\
8 \\
21 \\
15 \\
27 \\
2\end{array}$ & $\begin{array}{r}78 \\
76 \\
69 \\
67 \\
282 \\
86 \\
66 \\
66 \\
51 \\
293\end{array}$ & $\begin{array}{l}1.20 \\
1.17 \\
1.06 \\
1.03 \\
1.26 \\
1.32 \\
1.01 \\
.79 \\
1.43\end{array}$ & $\begin{array}{r}50 \\
41 \\
28 \\
17 \\
10 \\
22 \\
15 \\
27 \\
1\end{array}$ & $\begin{array}{r}1.0 \\
(1) \\
1.5 \\
2.7 \\
21.0 \\
1.5 \\
1.0 \\
5.0 \\
24\end{array}$ & $\begin{array}{r}0.40 \\
.60 \\
1.08 \\
.40 \\
.60 \\
.40 \\
2.00 \\
9.60\end{array}$ & $\begin{array}{r}42 \\
34 \\
32 \\
39 \\
10 \\
6 \\
15 \\
27 \\
2\end{array}$ & 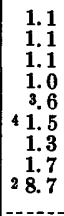 & $\begin{array}{r}1.00 \\
1.00 \\
1.00 \\
.91 \\
.55 \\
1.35 \\
1.18 \\
1.55 \\
7.90\end{array}$ \\
\hline $\begin{array}{l}\text { Kalauao Springs: } \\
\text { Inland orifice } \\
\text { Composite } \\
\text { Waiau Springs, composite- } \\
\text { Waiawa Springs: }\end{array}$ & $\begin{array}{r}19 \\
9 \\
27\end{array}$ & $\begin{array}{r}52 \\
2 \quad 52 \\
50\end{array}$ & $\begin{array}{l}1.45 \\
1.45 \\
1.39\end{array}$ & $\begin{array}{r}18 \\
9 \\
26\end{array}$ & $\begin{array}{r}397 \\
387 \\
85\end{array}$ & $\begin{array}{l}1.49 \\
1.34 \\
1.31\end{array}$ & $\begin{array}{r}19 \\
9 \\
27\end{array}$ & $\begin{array}{r}8.4 \\
27.8 \\
6.0\end{array}$ & $\begin{array}{l}3.36 \\
3.12 \\
2.40\end{array}$ & $\begin{array}{r}18 \\
9 \\
25\end{array}$ & $\begin{array}{r}2.7 \\
32.5 \\
32.4\end{array}$ & $\begin{array}{l}2.45 \\
2.27 \\
2.18\end{array}$ \\
\hline $\begin{array}{l}\text { Inland orifice. } \\
\text { Composite } \\
\text { Area } 11 \text { shaft 14. } \\
\text { wells }\end{array}$ & $\begin{array}{r}18 \\
\mathbf{9} \\
\mathbf{3} \\
7\end{array}$ & $\begin{array}{l}64 \\
260 \\
266 \\
261\end{array}$ & $\begin{array}{l}1.78 \\
1.67 \\
1.83 \\
1.70\end{array}$ & $\begin{array}{r}18 \\
9 \\
31 \\
6\end{array}$ & $\begin{array}{r}71 \\
266 \\
200 \\
2153\end{array}$ & $\begin{array}{l}1.09 \\
1.01 \\
\text { 3. } 08\end{array}$ & $\begin{array}{r}18 \\
9 \\
16\end{array}$ & $\begin{array}{l}12 \\
25.8 \\
16\end{array}$ & $\begin{array}{l}4.80 \\
2.32 \\
6.40\end{array}$ & $\begin{array}{r}\mathbf{1 8} \\
\mathbf{9} \\
\mathbf{3} \\
\mathbf{5}\end{array}$ & $\begin{array}{r}5.7 \\
23.4 \\
27.5 \\
28.4\end{array}$ & $\begin{array}{l}5.18 \\
3.09 \\
6.81 \\
7.63\end{array}$ \\
\hline $\begin{array}{l}\text { Representative uncon- } \\
\text { taminated basal water.- }\end{array}$ & & 36 & 1.00 & & 65 & 1.00 & & 2.5 & 1.00 & & 1.1 & 1.00 \\
\hline
\end{tabular}

1 Sulfate concentration less than in sea water of comparable chloride content.

2 Mean value.

3 Median value.

4 For period 1943-50. Nitrate increases after 1950 nitrate, possibly because of urbanization near shaft.

The wells and shafts in areas 1,2,3,4 and 5 are outside of and up the hydraulic gradient from the irrigated region. Shaft 12 in area 6 is near the eastern edge of Pearl Harbor area but is upgradient from the irrigated part, and its water, therefore, is similar to that of water from uncontaminated sources. Well 201 in area 6 lies below irrigated fields of Oahu Sugar Co.; it does not show marked effects from irrigation because it penetrates deep into the lens, where the return irrigation water does not have an opportunity to affect the mixture of intruded saline water and fresh water. On the other hand, water from shaft 3 in area 6, which is in the interior part of the Pearl Harbor area, clearly shows contamination. Shaft 3 is remote from the region of primary recharge and develops water immediately down the gradient from heavily irrigated fields. The water in the lens at shaft 3 is probably a mixture of return irrigation water, water from primary recharge, and intruded saline water. The shaft draws some water from the top part of the lens, where the effect of return irrigation water is greatest. 


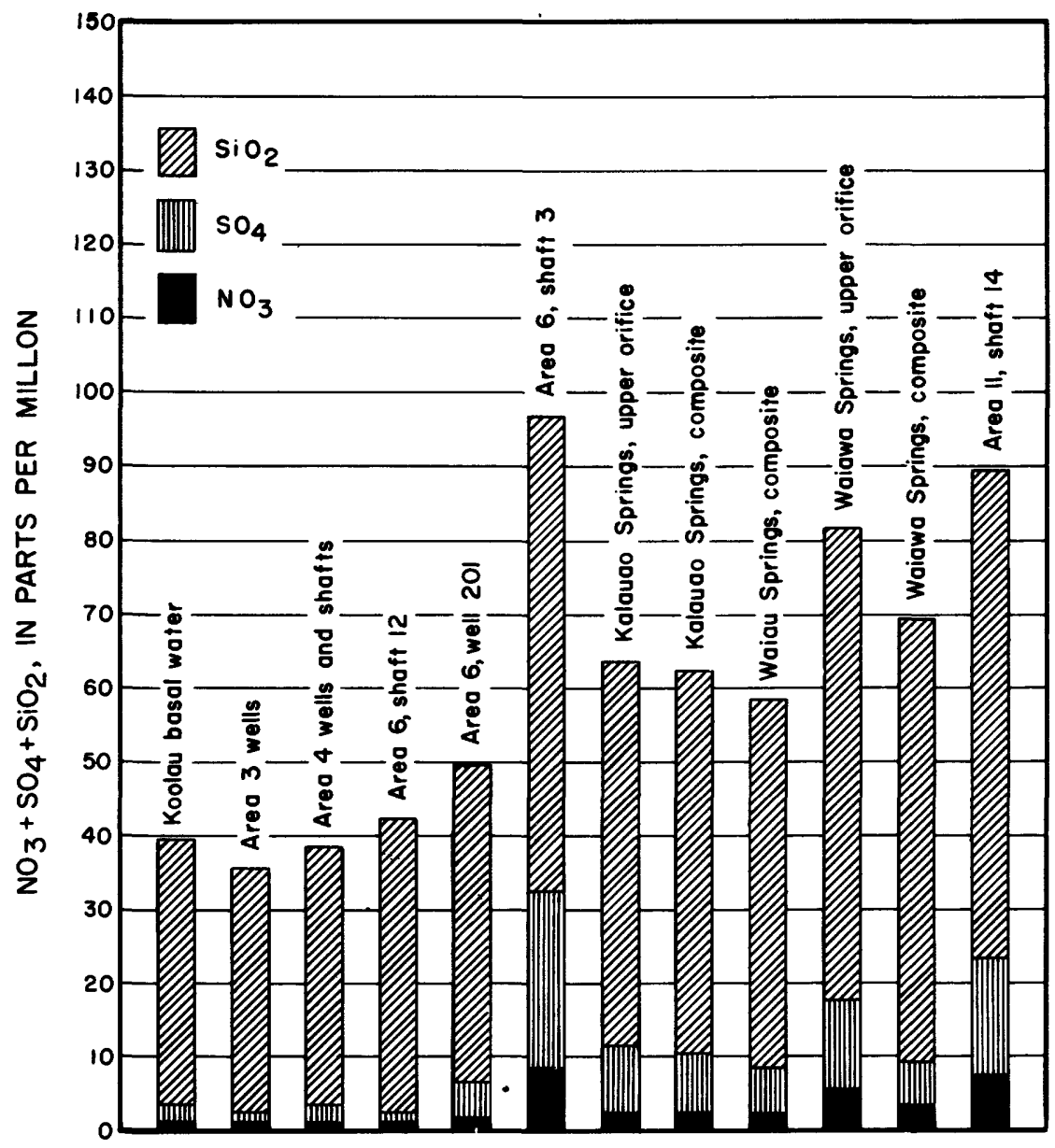

Figure 44.-Concentrations of nitrate, sulfate, and silica in water from various sources in southern Oahu. The five bars on the left of the graph showing relatively low concentrations are representative of sources having no return irrigation water. The bars showing higher concentrations are for sources affected by return irrigation water.

All the sampling points at springs are near the shore of Pearl Harbor below the irrigated fields of the Oahu Sugar Co. The springs discharge water that comes from all parts of the lens; the orifices farthest inland discharge water from near the top of the lens, and those nearer the shore discharge water from progressively deeper parts of the lens. The inland orifices listed in table 12 refer to the points of discharge farthest from the shore, and the composite sources refer to a mixture of all the water from the particular spring area. The inland orifices show the greatest effect from return irrigation water. 
Area 11, which is underlain by basaltic lava flows of both the Waianae and Koolau Volcanic Series, is represented in the tables by shaft 14 and several wells. The water in the Waianae aquifer consists largely of water moving across the boundary from the Koolau Volcanic Series and of irrigation water applied on the fields overlying the Waianae Volcanic Series. The shaft and wells lie down the hydraulic gradient from much of the irrigated area overlying both the Koolau and Waianae aquifers. As a result the water that they produce shows the effects of irrigation.

Nitrate.-Nitrate is an excellent indicator of the changes in basal water caused by irrigation water. In rain and uncontaminated stream water, it amounts to less than $0.5 \mathrm{ppm}$, and in uncontaminated basal water, it is analysed to be $1.1 \mathrm{ppm}$. Sea water and intruded saline water contains only small amounts of nitrate. Concentrations shown in table 12 indicate the manner in which percolating water from irrigated fields in the agricultural areas raises the nitrate content in the basal water. For example, shaft 3 in area 6 and shaft 14 and wells in area 11, which are in irrigated areas, indicate an increase of concentration of six to eight times that of uncontaminated water. The springs also show an increase. The sources outside the irrigated area show a close agreement with the nitrate content of the representative uncontaminated basal water.

Sulfate.-In table 12 the amount of sulfate that is added by irrigation water is calculated as that in excess of the amount brought in with intruded saline water. This calculation is based on the assumption that the composition of the intruded water is identical to that of sea water; however, the assumption is not necessarily correct, as is pointed out in the discussion of the geochemistry of intruded water (p. 97). However, since the intruded water contains less sulfate than sea water of comparable chloride content, the assumption results in a smaller sulfate content being computed than may actually be contributed by return irrigation. The relative increase in sulfate resembles that of nitrate and is of about the same magnitude for each of the sources in the irrigated area.

Silica.-The silica content of uncontaminated basal water is about $36 \mathrm{ppm}$. Greater concentrations are attributed to contamination from irrigation, because intruded saline water contains about the same quantity of silica as does the uncontaminated water.

The increase of silica follows the pattern of that of nitrate and sulfate, but the magnitude of the increase is considerably greater (fig. 44). The increases are rather uniform in all the irrigated areas.

Bicarbonate.-The bicarbonate content of uneontaminated water is $65 \mathrm{ppm}$, but significant increases in content occur in areas 1, 2, and 
5, which are not irrigated. The increases are probably related to the occurrence of the basalt and pyroclastic rock of the Honolulu Volcanic Series overlying the Koolau Volcanic Series in these areas. In area 6 , in which no rock of the Honolulu Volcanic Series occurs, the bicarbonate content of uncontaminated basal water is about $65 \mathrm{ppm}$, and concentrations greater than this suggest the effect of return irrigation water. The quantity of bicarbonate in uncontaminated water does not differ greatly from that in sea water and intruded saline water having a comparable chloride content. The most significant increases in bicarbonate follow the general pattern of those of nitrate, sulfate, and silica. The water from sources in area 11 is especially high in bicarbonate. The water from springs also shows a considerable increase over uncontaminated water, but well 201, which also is on the shore of Pearl Harbor, has a bicarbonate content less than that of uncontaminated water. The low bicarbonate content of water from well 201 suggests that the well is drawing water from a deep part of the lens that is not affected by return irrigation water.

\section{CAPROCK WATMGR}

Water in the caprock occurs in substantial quantities where fossil reefs are present. The permeability of the alluvium and marine muds, which with reef deposits make up most of the caprock, is low, but the reef rock is generally permeable and is locally extensive enough for the formation of Ghyben-Herzberg lenses. Fresh water in the lenses accumulates from rainfall, return irrigation, and leakage upward from the artesian part of the basaltic aquifer. The leakage may account for most of the unmeasured escape of water from the basaltic aquifers, and, as such, it may amount to large quantities of water.

Where reef deposits occur along the shore and extend below sea level, sea water commonly moves readily into the caprock. The ease of movement through the reef rock is indicated by high efficiency in transmitting tidal fluctuations. The discontinuous character of sediments within the caprock prevents the formation of continuous freshwater lenses over extensive areas, and intermittent poorly defined lenses are the rule.

A large quantity of fresh to brackish water occurs in the caprock, but because of its generally poor quality, it is used only for agricultural and industrial purposes. The chief area of development is on the Ewa plain, where for many years large amounts have been pumped for irrigation and where such industrial activities as steel fabrication, oil refining, and cement manufacture are developing additional supplies. In Honolulu small quantities of caprock water have been developed for air conditioning. 
Only a few chemical analyses of caprock water are available. Many chloride determinations are available, but these indicate merely the useability of the water. The few chemical data indicate certain characteristics that distinguish the caprock water from other types of water. The most pronounced of these characteristics are the high concentrations of carbon dioxide, bicarbonate, and calcium. The unusually large quantities of these constituents result from solution of the reef limestone and associated calcareous sediments in which the water occurs.

Table 13 indicates the carbon dioxide, bicarbonate, and chloride contents and the $\mathrm{pH}$ of caprock water from several sources and compares them with basal water from the basaltic aquifers in the same areas and with sea water. Calcium is not included in this table because its concentration is largely a function of chloride content, whereas the other constituents are essentially independent of the chloride. The data illustrate that equilibria in the system $\mathrm{CO}_{2}-\mathrm{H}_{2} \mathrm{O}-\mathrm{CaCO}_{3}$ can be employed to distinguish caprock water from other natural water.

Table 14 indicates constituents whose concentrations vary with chloride content. The table gives analyses of caprock water, water from basaltic aquifers that has about the same chloride content as the cap-

TABLE 13.-Comparison of $p H$ and concentrations, in parts per million, of carbon dioxide, bicarbonate, and chloride in caprock water, basalt aquifer water, and sea water

[A nalyses of water from area 1 by Honolulu Board of Water Supply; area 11 (Ewa) by Hawaii State Board of Health; and area 11 (shaft 14) by U.S. Navy]

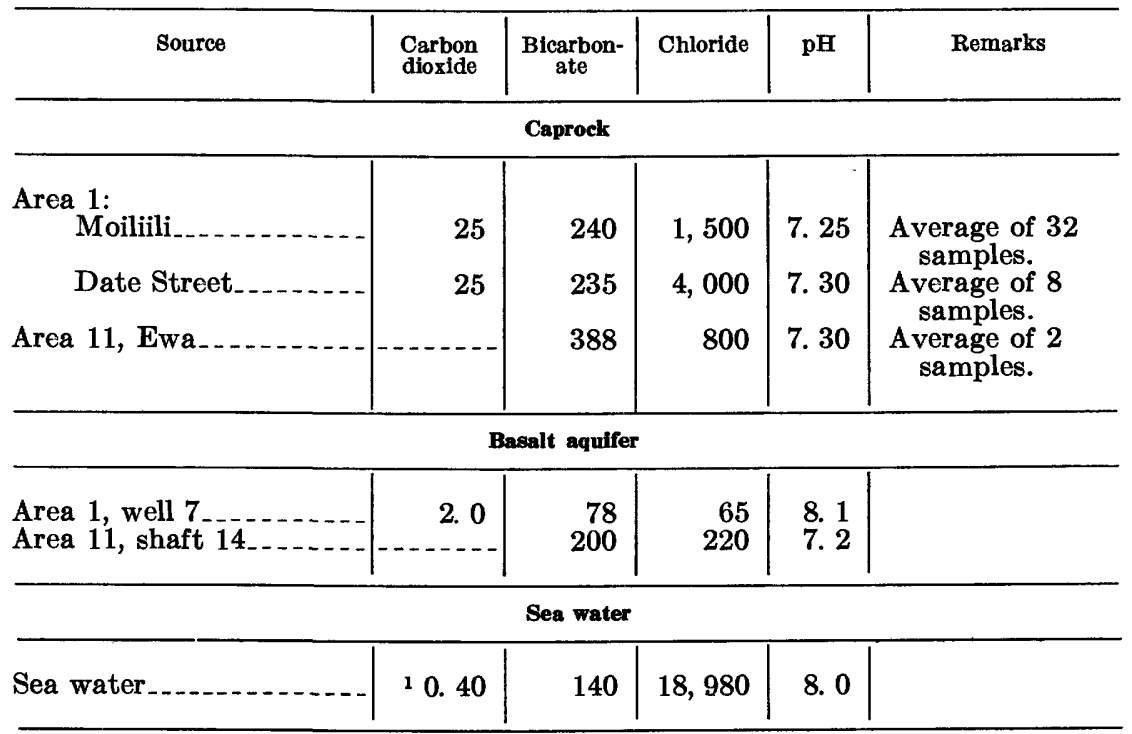

1 Calculated by assuming that the carbon dioxide in the atmosphere is in equilibrium with the sea. 
TABLE 14.-Comparison of concentrations, in equivalents per million, of constituents that vary with chloride concentration in water in the caprock and the basalt aquifer and in sea water

[Ratio: constituent concentration to chloride concentration for each source]

\begin{tabular}{|c|c|c|c|c|c|c|c|c|c|c|}
\hline \multirow[t]{2}{*}{ Source } & \multirow{2}{*}{$\begin{array}{l}\text { Chlo- } \\
\text { ride }\end{array}$} & \multicolumn{2}{|c|}{ Calcium } & \multicolumn{2}{|c|}{ Magnesium } & \multicolumn{2}{|c|}{$\begin{array}{c}\text { Sodium } \\
+ \\
\text { Potassium }\end{array}$} & \multirow{2}{*}{$\begin{array}{c}\text { Cations/CI } \\
\text { ratio }\end{array}$} & \multicolumn{2}{|c|}{ Sulfate } \\
\hline & & Epm & Ratio & Epm & Ratio & Epm & Ratio & & Epm & Ratio \\
\hline \multirow{2}{*}{$\begin{array}{l}\text { 1. Caprock. } \\
\text { 2. Basalt. } \\
\text { 3. Caprock. } \\
\text { 4. Basalt } \\
\text { 5. Caprock } \\
\text { 6. Sea water..... }\end{array}$} & \multirow{2}{*}{$\begin{array}{c}44.0 \\
45.0 \\
525 \\
210 \\
5.64 \\
535\end{array}$} & \multirow{2}{*}{$\begin{array}{l}6.99 \\
5.14 \\
83.7 \\
55.8 \\
1.48 \\
20.0\end{array}$} & \multirow{2}{*}{$\begin{array}{r}0.159 \\
.114 \\
.159 \\
.266 \\
.262 \\
.037\end{array}$} & \multirow{2}{*}{$\begin{array}{l}9.70 \\
11.5 \\
34.5 \\
121 \\
3.10 \\
105\end{array}$} & \multirow{2}{*}{$\begin{array}{r}0.220 \\
.256 \\
.066 \\
.576 \\
.550 \\
.196\end{array}$} & $\begin{array}{l}35.7 \\
34.8\end{array}$ & $\begin{array}{r}0.811 \\
.773\end{array}$ & $\begin{array}{l}1.19 \\
1.14\end{array}$ & $\begin{array}{l}4.75 \\
5.52\end{array}$ & $\begin{array}{r}0.108 \\
.123\end{array}$ \\
\hline & & & & & & $\begin{array}{r}54.0 \\
4.00 \\
469\end{array}$ & $\begin{array}{l}.257 \\
.709 \\
.877\end{array}$ & $\begin{array}{l}1.10 \\
1.52 \\
1.11\end{array}$ & $\begin{array}{l}17.0 \\
55.66\end{array}$ & $\begin{array}{l}.081 \\
.117 \\
.103\end{array}$ \\
\hline
\end{tabular}

1. Moiliili, area 1. Analyses by Honolulu Board of Water Supply.

2. Well 25, area 1. Analyses by Honolulu Board of Water Supply.

3. Well 90-7, area 2. Analyses by Hawaiian Sugar Planters' Experiment Station.

4. Well 101, area 2. Analyses by Honolulu Board of Water Supply.

5. Waianae area. Analyses by Hawail State Board of Health.

rock water, and sea water. Ratios of the concentration of each constituent to that of chloride are given to indicate whether significant differences exist between the waters. Concentrations are given in equivalents per million in order to show the variation caused by ion exchange and to show whether significant solution of material in the caprock has taken place. The amount of cations contributed by solution in the caprock is indicated by the increase in the ratio of the total cations to chloride of each sample over that of sea water. Positive deviations occur, but they are slight and indicate that solution in the caprock is not a major contributor to the dissolved-solids content.

The sample from the Moiliili caprock, in area 1, has a considerably higher ratio of calcium to chloride than either the water in basalt from the same area or sea water, but the total cation to chloride ratio approximates that of sea water. This approximation indicates that the excess calcium is obtained by cation exchange in the sediments within the caprock. The chloride content of water from well 90-7, in area 2, is almost equal to the chloride content of sea water, but the water is enriched by calcium, probably by the same means as in the Moiliili sample. Well $90-7$ is less than 800 feet from the shore. The ratio of magnesium to chloride in the Moiliili water indicates a slight magnesium enrichment as compared to sea water, but that in water of well 90-7 shows a deficit. The complexities of cation exchange apparently favor the release of calcium from the exchange positions.

Water from the caprock in the Waianae Valley has marked increases in both calcium and magnesium compared with those in sea water having a comparable chloride content and has a higher ratio of total cations to chloride. The calculated amount of solution, however, is 
small, and as in the Moiliili and well 90-7 water samples, cation exchange in the caprock accounts for most of the increases of the calcium and magnesium in the water.

The sulfate content of caprock water does not vary greatly from that of sea water having comparable chloride content. Not enough analyses are available to generalize, but the available data suggest that sulfate reduction is not important within the caprock. It should be noted, however, that the two sulfate values for caprock water are for samples taken at a shallow depth in the caprock. At greater depths sulfate reduction may occur, as it does in intruded saline water in the basalt.

\section{TEMPHRATURE OF THE WATHR}

The temperature of the ground water of southern Oahu varies within narrow limits in both time and in place. The principal influence on the temperature of the fresh water is the atmosphere, where the water in the form of rain reaches the temperature that dominates through the hydrologic cycle. The temperature of the rain is generally the lowest ever reached by the water; thereafter, every change ieads to. higher temperatures. The temperature is affected also by solar heating of the earth's surface, the geothermal gradient, and frictional heating as the water flows through the aquifer to the sea. A less widespread effect is the temperature of return irrigation water.

The magnitude of the various effects other than that of the atmosphere cannot be assessed accurately, but the most important effect is probably that of the heat absorbed by the water as it passes through the soil and vegetative layer. This occurrence is especially true at lower altitudes where the ground surface is exposed to the sun for long periods. The effect of the geothermal gradient on the temperature of the fresh water is probably small. Information from deep test hole T-67 indicates a virtual absence of a geothermal gradient in the fresh-water lens. Frictional heating of the water during its passage to the sea may cause a small increase in temperature. If all potential energy were converted to heat by the time the water enters the sea, the increase in temperature would be somewhat more than $1^{\circ} \mathrm{F}$.

The increase in the temperature of the basal water that is caused by return irrigation water may be noticeable locally. Irrigation water is exposed to the heating effect of sunshine at low altitudes in open reservoirs and in ditches to the fields, and it also may be warmed by contact with the soil. As a result, the part that percolates to the aquifer may have a considerably higher temperature than the basal water with which it mixes. 
In Honolulu near sea level the average temperature is $75.2^{\circ} \mathrm{F}$, and the difference between the averages of the coldest and warmest months is only $6.5^{\circ} \mathrm{F}$. At an altitude of 1,400 feet in the hills behind Honolulu, the average is $69.2^{\circ} \mathrm{F}$, and the seasonal difference is $5.0^{\circ} \mathbf{F}$. Computed on the basis of the temperatures at these localities, the average change in temperature with altitude is $4.3^{\circ} \mathrm{F}$ per thousand feet. No long-term records are available for altitudes higher than 1,400 feet, but data collected over a period of several months by Hosaka ${ }^{3}$ in the Kipapa Stream basin give a weighted average gradient of $5.1^{\circ} \mathrm{F}$ per thousand feet, the gradient diminishing in magnitude at higher altitudes. Irregular readings taken in the same area during several years as part of the present investigation give an average gradient of $5.9^{\circ} \mathrm{F}$ per thousand feet and agree with those of Hosaka in a decrease in the gradient at higher altitudes. The fact that the gradient in the Kipapa Stream area is higher than that in the Honolulu area is probably caused by the more extensive cloud cover in the central Koolau Range. The cloud cover also would have the effect of decreasing the gradient at higher altitudes.

Computed on the basis of the gradient of $5.1^{\circ} \mathrm{F}$ in the Kipapa Stream basin, the average annual temperature on the highest place in the Koolau Range would be $59.9^{\circ} \mathrm{F}$ and in the Waianae Range, $54.8^{\circ}$ F. These temperatures would be the averages for the coldest rain striking the ground, provided the surface atmosphere and the rainfall were in equilibrium with respect to temperature. Only small areas lie at such extreme altitudes, however, and the amount of rain that falls on them is very small compared to the total rainfall in the principal zone of recharge. If the average altitude of the zone of recharge is assumed to be 1,500 feet, the temperature of the rainfall there would be $67.5^{\circ} \mathrm{F}$.

The temperature of the rainfall at the time it hits the ground may be lower than the atmospheric temperature at the ground surface. Most of the rainfall in the mountain region is from orographic showers that fall from clouds lying below the inversion layer. The top of the clouds lies near the base of the inversion layer at about 6,000 feet, and the bottom is at an altitude of 2,000-3,000 feet. The middle of the clouds is probably at about 4,000 feet, and, therefore, if the free atmospheric lapse rate applies, the average temperature of the rain as it falls from the cloud would be $55.2^{\circ} \mathrm{F}$. The temperature probably rises as the rain descends but perhaps not at a rate

\footnotetext{
3 Hosaka, E. Y., 1935, Floristic and ecological studies in Kipapa Gulch, Oahu : Unpublished thesis on file with the University of Hawail, Honolulu.
} 
great enough to reach equilibrium with the atmosphere at the ground surface. However, information on soil and ground-water temperatures in the mountains suggests that the temperature of the rain as it strikes the ground is nearer that of the atmosphere at the ground surface than that of the orographic cloud.

\section{TEMPERATURE OF RECHARGE WATER}

The foregoing discussion suggests that the average temperature of the rainfall in the middle of the main recharge area in the Koolau Range is about $67^{\circ} \mathrm{F}$. Information on soil temperatures collected by Hosaka ${ }^{4}$ is probably a better indicator of the actual temperature of the water as it passes through the soil mantle into the rocks below. Hosaka's data, which are summazired in table 15, were collected from the Kipapa Stream basin at various altitudes during the period from March through November 1933. Between the altitudes of 250 feet and 2,200 feet, the gradient at a depth of 90 centimeters - the deepest point of the profile-is $7.6^{\circ} \mathrm{F}$ per thousand feet, which is probably a somewhat high determination as a result of anomalous heating at the 250-foot station. Between stations at 750 feet and 2,200 feet, the gradient at 90 centimeters below the ground surface is $4.9^{\circ} \mathrm{F}$ per thousand feet, which corresponds well with the average atmospheric gradient of 5.1 $\mathrm{F}$ used for Kipapa Stream area and with the free atmosphere lapse rate.

The lowest temperature shown in table 15 is $65.4^{\circ} \mathrm{F}$ at the 90 -centimeter depth at 2,200 feet, and the highest is $80.2^{\circ} \mathrm{F}$ at 90 centimeters at 250 feet. Since only a small part of the total recharge to the aquifer originates at the low altitude, however, it would be more appropriate to use the temperature at the 750 -foot station, $72.5^{\circ} \mathrm{F}$, to indicate the higher limit of the temperature of primary recharge. If the midpoint

TABLE 15.-Soil temperatures, in degrees Fahrenheit, at various depths below ground surface in the Kipapa Stream basin

[After Hosaka, E. Y., 1935, Floristic and ecological studies in Kipapa Gulch, Oahu: Hawaii Univ., unpub. thesis]

\begin{tabular}{|c|c|c|c|c|}
\hline \multirow{2}{*}{ Altitude (feet) } & \multicolumn{4}{|c|}{ Temperature at depth (centimeters) indicated- } \\
\hline & 15 & 30 & 60 & 90 \\
\hline $\begin{array}{l}250 \\
\mathbf{7}, 000 \\
1,500 \\
1,600 \\
2,200\end{array}$ & $\begin{array}{l}87 \\
75.1 \\
73.2 \\
\text { 70. } 3 \\
67.9 \\
65.8\end{array}$ & $\begin{array}{l}\text { 82. } 3 \\
72.9 \\
71.6 \\
69.3 \\
67.2 \\
65.9\end{array}$ & $\begin{array}{l}\text { 81. } 1 \\
72.7 \\
71.3 \\
69.1 \\
67.4 \\
65.8\end{array}$ & $\begin{array}{l}\text { 80. } 2 \\
72.5 \\
70.8 \\
67.8 \\
67.1 \\
65.4\end{array}$ \\
\hline
\end{tabular}

1 Values obtained by interpolation between values for 750 and for $2,200 \mathrm{ft}$.

4 See footnote 3, page 119. 
of recharge is at 1,500 feet, the interpolated average temperature of the soil at 90 centimeters, and therefore of ground water infiltrating in the mountain area, is $67.8^{\circ} \mathrm{F}$. The combined evidence from soil and atmospheric temperatures indicates that the average temperature of the infiltrating ground water is between $65^{\circ} \mathrm{F}$ and $70^{\circ} \mathrm{F}$. The midpoint between these values, $67.5^{\circ} \mathrm{F}$, is a reasonable value to use in the central Koolau Range.

Other information on the temperature of the ground water in the main areas of recharge is available from measurements made in tunnels driven to develop water in dike compartments. The tunnels penetrate beneath the higher parts of the Koolau and Waianae Ranges and collect water that has traveled distances of a few tens of feet to several hundred feet below the land surface. Table 16 gives the averages of temperatures taken at different times of the year in several tunnels in the Koolau Range. The individual measurements characteristically indicate no seasonal variation. The table lists also the altitudes of the tunnels and the altitude of the highest ground surface above the tunnels. The tunnels are listed in order of decreasing altitude of the overlying surface. The figures indicate only roughly the altitudes at which the water originated from rainfall.

Data for several high-level springs in the mountains behind Honolulu also give information on the temperature of water during infiltration. At Kahuauai Spring ( $618 \mathrm{ft}$ above sea level), four measurements made at different times of the year gave an average of $68.4^{\circ}$ F. Several measurements at Booth Spring (709 ft) also gave an average of $68.4^{\circ} \mathrm{F}$. A single measurement at Herring Spring $(970 \mathrm{ft})$ gave $68.0^{\circ} \mathrm{F}$, and one at Makiki Spring $\left(976 \mathrm{ft}\right.$ ) gave $67.0^{\circ} \mathrm{F}$. The data from tunnels and springs indicate a decrease in water temperature with altitude and suggest that the average intake temperature of water in the mountains is about $67.5^{\circ} \mathrm{F}$.

TABLE 16.-Average ground-water temperatures in tunnels in the Koolau Range

\begin{tabular}{|c|c|c|c|}
\hline Tunnel & $\begin{array}{l}\text { Altitude of } \\
\text { portal } \\
\text { (feet) }\end{array}$ & $\begin{array}{l}\text { Altitude of max- } \\
\text { imum overlying } \\
\text { surface } \\
\text { (feet) }\end{array}$ & $\begin{array}{c}\text { Average tem- } \\
\text { perature } \\
\left({ }^{\circ} \mathrm{F}\right)\end{array}$ \\
\hline $\begin{array}{l}\text { Uwau. } \\
\text { Waikane No. } 1 \\
\text { Waiahole (Main) } \\
\text { Kahana } \\
\text { Palolo }{ }^{1} \\
\text { Nuuanu } 4 \bar{B}^{1}{ }^{1} \\
\text { Manoa } 3{ }^{1} \\
\text { Nuuanu } 3{ }^{1} \\
\text { Manoa } 1{ }^{1} \\
\text { Manoa } 2 \text { }\end{array}$ & $\begin{array}{l}800 \\
800 \\
790 \\
800 \\
995 \\
968 \\
760 \\
810 \\
550 \\
550\end{array}$ & $\begin{array}{r}2,500 \\
2,400 \\
2,300 \\
2,200 \\
1,150 \\
1,000 \\
850 \\
850 \\
650 \\
550\end{array}$ & $\begin{array}{l}\text { 65. } 0 \\
65.0 \\
65.0 \\
65.0 \\
65.7 \\
67.6 \\
66.2 \\
69.0 \\
68.0 \\
68.3\end{array}$ \\
\hline
\end{tabular}

1 Data from Honolulu Board of Water Supply. 
In the high parts of the Waianae Range, the few temperature measurements that have been obtained in tunnels indicate that the ground water is several degrees colder than that in the Koolau Range. A series of readings made at tunnel 19 , on the west slope of Kaala, which penetrates 1,100 feet into the mountain at an altitude of 1,515 feet, gave an average water temperature of $62.8^{\circ} \mathrm{F}$; individual readings varied very little. The temperature of the water in the Waianae tunnel of the Honolulu Board of Water Supply is $70.2^{\circ} \mathrm{F}$ at the portal; but the, portal is only 418 feet above sea level, and the altitude of the ground surface over the first half of its 10,340-foot length is less than 1,000 feet. The flow from the tunnel is only about a mgd; the long distance traveled by the water in the warm surroundings of low altitude and the fraction of water contributed at low altitude are probably the causes of the relatively high temperature of water at the portal.

\section{TEMPERATURE OF THE BASAL AQUIFER}

Water discharging from the basal aquifer, either naturally or at wells and shafts, is measurably warmer than water in the mountain recharge area. During the present investigation, extensive temperature records were obtained on flowing artesian wells and springs in the central part of the Pearl Harbor basin. Records of temperature of water in wells and shafts in the Honolulu area have been obtained by the Honolulu Board of Water Supply for many years.

Differences between the temperatures of water infiltrating in the mountains and water discharging near the coast amount to several degrees. Small variations in the amount of change occur among different areas, but their significance is questionable. Average temperatures of water in the different isopiestic areas of the Honolulu region are shown in table 17. The temperatures are the averages of three carefully taken readings at each station in June, September, and December of 1938 (Honolulu Board of Water Supply, 1939, p. 155).

In the central Pearl Harbor area 23 readings at flowing artesian wells gave an average water temperature of $69.4^{\circ} \mathrm{F}$ and a range of

TABLE 17.-Temperatures of ground water from wells and shafts in the Honolulu area

\begin{tabular}{|c|c|c|c|}
\hline \multirow{2}{*}{ Area } & \multirow{2}{*}{ Source } & \multicolumn{2}{|c|}{ Temperature $\left({ }^{\circ} \mathrm{F}\right)$} \\
\hline & & A verage & Range \\
\hline $\begin{array}{l}1 \\
4_{2}\end{array}$ & $\begin{array}{r}\text { Well } 77 \\
88 \\
128 \\
\text { Shaft } 6 \\
7\end{array}$ & $\begin{array}{l}\text { 70. } 5 \\
\text { 71. } 6 \\
\text { 69. } 7 \\
\text { 70. } 7 \\
\text { 71. } 0\end{array}$ & $\begin{array}{l}\text { 70. } 4-70.5 \\
\text { 71. } 6-71.6 \\
\text { 69. } 7-69.7 \\
\text { 70. } 7-70.9 \\
\text { 70. 9-71. }\end{array}$ \\
\hline
\end{tabular}


$68.5^{\circ}-71.4^{\circ} \mathrm{F}$. The lower average temperature of the ground water in the Pearl Harbor area suggests that a greater proportion of the water enters the aquifer at higher altitudes than it does in the Honolulu area and perhaps that it remains in the aquifer for a shorter time. Return irrigation water apparently does not significantly affect the temperature of the Pearl Harbor well water, probably because much of the water flowing from wells comes from deep in the lens. If $67.5^{\circ} \mathrm{F}$ is the average temperature of the recharge water in the central Koolau Range, then the rise in temperature of the water along its path from recharge to discharge is only about $2^{\circ} \mathrm{F}$.

The warming effect of return irrigation water is noticeable in springs on the shore of Pearl Harbor at the orifices in basalt along the inland margins of spring zones. The inland orifices discharge water from the top part of the lens, where return irrigation water tends to be concentrated. In general, temperature readings taken at orifices in alluvium near the discharge points in basalt are anomalous, probably because the low permeability of the alluvial sediments slows the escape of water and allows it to be affected by solar heating.

Table 18 gives the average and range of temperatures of water at springs on the shore of Pearl Harbor. All measurements were made in water flowing freely from orifices in basalt in a volume that was probably great enough to preclude the effects of solar warming. , The data were collected at different times of the year, during which no significant seasonal effects were noted. The average water temperatures among the spring areas are in close agreement. The average of water temperatures at all the springs is $70.5^{\circ} \mathrm{F}$, and the range is $69.3^{\circ}-$ $72.0^{\circ} \mathrm{F}$. In drilled wells in the same general area, the average temperature of the water is $69.4^{\circ} \mathrm{F}$, and the range is $68.5^{\circ}-71.4^{\circ} \mathrm{F}$. The difference between the averages, $1.1^{\circ} \mathrm{F}$, can be attributed principally to the effect of mixing of warmed return irrigation water with the basal water. This conclusion is supported by the fact that water discharging from deep in the lens at the seaward edge of spring areas has lower temperatures than the water flowing from inland orifices.

TABLE 18.-Temperatures of water flowing from the Pearl Harbor springs

\begin{tabular}{|c|c|c|c|}
\hline \multirow{2}{*}{ Spring } & \multirow{2}{*}{$\begin{array}{c}\text { Number of } \\
\text { measurements }\end{array}$} & \multicolumn{2}{|c|}{ Temperature $\left({ }^{\circ} \mathrm{F}\right)$} \\
\hline & & Average & Range \\
\hline $\begin{array}{l}\text { Kalauao } \\
\text { Waiau } \\
\text { Waimano } \\
\text { Waiawa } \\
\text { Waikele }\end{array}$ & $\begin{array}{r}17 \\
11 \\
9 \\
8 \\
4\end{array}$ & $\begin{array}{l}\text { 70. } 8 \\
\text { 70. } 1 \\
\text { 70. } 6 \\
\text { 70. } 4 \\
\text { 70. } 2\end{array}$ & $\begin{array}{l}\text { 70. } 3-71.2 \\
69.8-72.0 \\
69.3-71.7 \\
69.6-71.4 \\
70.2-70.2\end{array}$ \\
\hline
\end{tabular}


At Kalauao Springs the average temperature of the water that flows freely through orifices in alluvium about 800 feet seaward from the inland margin of the springs is $69.8^{\circ} \mathrm{F}$; this temperature is $1^{\circ}$ cooler than the average of the water flowing at the inland margin and $0.5^{\circ}$ cooler than the coldest temperature recorded in water at the inland margin. The chloride content of the water at the seaward orifices is about $560 \mathrm{ppm}$ compared with about $100 \mathrm{ppm}$ at the inland orifices. At Waimano Springs water discharging from alluvium about 850 feet seaward of the inland margin has an average temperature of $69.8^{\circ} \mathrm{F}$, and the average water temperature at the inland edge is $70.6^{\circ} \mathrm{F}$.

In summary, in the Pearl Harbor area the increase in temperature of ground water between recharge and discharge as a result of effects other than return irrigation water is about $2^{\circ} \mathrm{F}$. Where return irrigation water mixes with basal water, the increase is about $3^{\circ} \mathrm{F}$, or a net increase due to irrigation of about $1^{\circ} \mathrm{F}$. In the artesian part of the Honolulu area, the water is about $1^{\circ} \mathrm{F}$ warmer than in the Pearl Harbor area. This difference is probably due to significant recharge at low altitudes.

\section{TEMPERATURE OF INTRUDED SALINE WATER}

Measured temperatures of water discharging from the GhybenHerzberg lens at wells in the Honolulu area and at wells and springs in the Pearl Harbor area seem to be independent of the chloride content, except where the effects of return irrigation water are significant. This fact suggests that the temperature does not vary with depth. The maximum chloride content in water for which temperature measurements were made was $3,000 \mathrm{ppm}$, and the temperature data, therefore, would apply strictly only to the fresher part of the lens. However, the question as to whether a uniform temperature prevails throughout the entire depth of the lens was resolved by measurements made in test hole $\mathrm{T}-67$, which penetrates through the lens into the underlying intruded saline water. The measurements indicate that the temperature is independent of both chloride content and depth at chloride concentrations less than $13,000 \mathrm{ppm}$ (about 69 percent sea water) and perhaps less than $16,900 \mathrm{ppm}$ (about 90 percent sea water). At some point between these two concentrations, the temperature probably begins to rise; it then rises several degrees as the chloride content approaches that of sea water. The maximum chloride content in water for which a temperature was obtained was $17,500 \mathrm{ppm}$ (92 percent sea water), and the most saline water underlying the lens may possibly have a temperature somewhat higher than the warmest recorded in the test hole. 
Table 19. lists the recorded temperature of water in test hole $\mathbf{T}-67$ at specific depths and the temperature of composite flow from the well. Water samples for determination of chloride content were obtained from the various depths by plugging the hole above and below a selected depth and then by allowing free artesian flow or by pumping at a rate of about $10 \mathrm{gpm}$. The measurements on composite samples were made on free artesian flow of water from throughout the depth of the hole. The chloride content of the free flow suggests that most of the water originated in the upper part of the lens. Measurements of temperature were made in the water as it discharged at the surface.

The temperatures of the fresh-water lens and the intruded saline water reflect the difference in the nature of their equilibrium states. In the lens a dynamic situation prevails that is characterized by relatively rapid changes in response to variations in recharge and discharge. A comparatively static situation exists beneath the lens, but an intermediate condition probably exists where the lens merges with the intruded saline water. The relatively static condition of the water under the lens is a result of the caprock barrier that retards

TABLE 19.-Temperature, in degrees Fahrenheit, and chloride concentration, in parts per million, of water at various depths below sea level in test hole T-67

[Single measurements unless otherwise indicated. Composite determinations are on free artesian flow from hole]

\begin{tabular}{|c|c|c|c|}
\hline Depth (feet) & Date & Chloride & Temperature 1 \\
\hline $\begin{array}{l}\mathbf{6} \\
\mathbf{6} 13\end{array}$ & $\begin{array}{c}1958 \\
\text { Feb. } 11 \\
\text { do. } \\
\text { do. do. } \\
\text { do. do. } \\
\text { Feb. } 10 \\
\text { Jan. } 29 \\
\text { Feb. } 27 \\
\text { do. } \\
\text { Mar. } 18 \\
20 \\
\text { Apr. } 10 \\
\text { Aug. } 14 \\
1959 \\
\text { Jan. } 6 \\
1958 \\
\text { Feb. } 27\end{array}$ & $\begin{array}{r}2,080 \\
2,530 \\
5,005 \\
5,130 \\
6,310 \\
9,435 \\
13,280 \\
16,875 \\
17,500 \\
1,631 \\
1,600 \\
1,600 \\
1,620 \\
1,565 \\
\\
1,515\end{array}$ & $\begin{array}{r}71.0 \\
71.0 \\
71.0 \\
71.0 \\
71.0 \\
71.0 \\
71.0 \\
71.0 \\
74.5 \\
273.94 \\
370.97 \\
470.52 \\
470.07 \\
470.52 \\
470.61\end{array}$ \\
\hline
\end{tabular}

\footnotetext{
1 Measurements with thermometer calibrated to $1.0^{\circ} \mathrm{F}$, unless stated otherw ise.

2 Measurements with thermometer calibrated to $0.1^{\circ} \mathrm{C}$. A verage of 8 readings with range from $73.58^{\circ}$ to 74.08 $\mathrm{F}$.

${ }^{3}$ Measurements with thermometer calibrated to $0.1^{\circ} \mathrm{C}$. Average of 5 readings with range from $70.88^{\circ}$ to $71.28^{\circ} \mathrm{F}$.

4 Measurements with thermometer calibrated to $0.1^{\circ}$.C.
} 
the easy movement of sea water in and out of the island. Because of its relative immobility, the water under the lens is warmed by the heat flow in the earth along the geothermal gradient. On the other hand, no evidence of the geothermal gradient is apparent in the lens, probably because very large quantities of water pass through it in time intervals that are small in comparison with the length of time necessary for establishment of thermal equilibrium.

If the caprock were absent, the temperature of the saline water below the lens would possibly be as low as or lower than that of water in the lens. In the open sea the temperature decreases rapidly with depth, and a similar relationship would be expected to occur in the rocks of the island if there were substantial movement of sea water in them. Results of temperature surveys in deep holes on the Pacific islands of Eniwetok and Bikini, which are small coral atolls uncomplicated by caprock, indicate that the water temperature there decreases with depth to a minimum of $43.5^{\circ} \mathrm{F}$ at $3,180-3,380$ feet below sea level before reversing and increasing with depth (Swartz, 1958). The decrease in temperature with depth parallels a similar decrease in the surrounding ocean water. Below the depth of minimum temperature, the increase with depth is approximately $0.011^{\circ} \mathrm{F}$ per foot, which is near the average terrestrial gradient of $0.018^{\circ} \mathrm{F}$ per foot.

Because the saline water below the lens in Oahu originated in the surrounding sea, its original temperature must have been the same as that of the water found at the depth at which it entered the permeable basalts. The toe of the caprock off Pearl Harbor is about 1,300 feet below sea level, which is also the depth of test hole T-67. At this depth the temperature of the water in the surrounding open sea is $47.3^{\circ} \mathrm{F}$, according to data obtained by the Pacific Oceanic Fishery Investigations (Seckel, 1955). Thus, water intruding from this depth increased in temperature from $47.3^{\circ} \mathrm{F}$ to $74.0^{\circ} \mathrm{F}$ during its movement and residence in the basalt. Some sea water possibly enters the island from depths less than 1,300 feet, but even at 650 feet below sea level, the temperature of the sea water is $63^{\circ} \mathrm{F}$ (Seckel, 1955), which is considerably cooler than that of the saline water under the lens. Appreciable warming of the intruded saline water, therefore, does occur.

\section{SUMMARY}

The basal ground water in southern Oahu is in a virtually continuous but compartmented aquifer that has a generally high permeability and in which the fresh-water supply floats on sea water. The slightly greater density of the sea water and the flow of fresh water through the aquifer toward the sea tend to keep the fresh water and salt water 
separate. The balance between the fresh and salt water is delicate, however, and a well may produce water of high or increasing salinity if it is too deep, too close to the shore, too heavily pumped, or pumped intermittently or if a well farther inland is pumped too heavily, especially if that pumping is intermittent.

Under conditions of equilibrium established by long-term patterns of development, use, and draft of basal water, no overall deterioration in water quality has occurred; but local increases in salinity have occurred, and some wells have been abandoned because of increasing salinity.

The recharge of water from irrigated sugarcane fields overlying the basal aquifer-including the recharge from high-level water diverted from windward Oahu and water pumped from the Pearl Harbor springs - is an important component of the basal ground-water system in the Pearl Harbor area.

The only additional water available for development in the Pearl Harbor area is the water flowing from the Pearl Harbor springs and nearshore wells into Pearl Harbor. During a period of minimum flow and maximum demand in 1953 and 1954, about $44 \mathrm{mgd}$ of basal water of good chemical quality flowed into the harbor from the springs and nearshore wells. The most direct approach to development of the additional water would be to collect the water downstream from the sites of industrial use and wetland irrigation and to pump it to areas of need.

An increase in the net draft on the aquifer by pumping from wells inland from the Pearl Harbor springs would recover some of the water now flowing into the sea, but it would also upset the equilibrium established under the present pattern of development, draft, and use. Development of the water now flowing from the Pearl Harbor springs and nearshore wells by means of wells established inland from the springs would decrease the flow of the springs and wells and cause an increase in salinity of the water flowing from them. It also would cause higher salinities at existing pumping stations that have wells extending into the transition zone.

Additional water may be developed in areas 1 and 2 (pl. 1). The amount can be determined best by gradually increasing the pumpage and observing the effects on the heads and the salinity of the water. Increased pumpage in the areas would cause a thinning of the lens and salt-water encroachment, but the effect of any given increase on the salinity of water in wells cannot be predicted at this time. Areas 3 and 4 probably are largely tributary to the Pearl Harbor springs and hence cannot be treated separately from the Pearl Harbor area (area 6$)$. 
The fresh basal water is suitable for domestic and agricultural use. Deterioration in quality occurs mainly in areas of sea-water intrusion where a mixture that has the approximate chemical character of diluted sea water is produced in the zone of transition between salt water and fresh water. Some chemical contamination occurs also at the basal water table underlying cultivated areas because of the deep infiltration of irrigation water pumped from wells penetrating the transition zone and of water carrying fertilizer salts in solution.

\section{REFERENCES}

Ayres, A. S., 1955, Forms of fertilizer material in relation to efficiency of utilization : Hawaiian Planters' Rec., v. 55, no. 1, p. 65-75.

Badon Ghyben, W., 1889, Nota in verband met de voorgenomen put boring nabij Amsterdam : K. inst. ing. Tijdschr., 1888-89, The Hague, p. 21.

Cline, M. G., 1955, Soil survey of the Territory of Hawaii : U.S. Dept. Agriculture, Soil Survey Ser. 1939, no. 25, 644 p.

Cooper, H. H., Jr., 1959, A hypothesis concerning the dynamic balance of fresh water and salt water in a coastal aquifer: Jour. Geophys. Research, v. 64, p. 461-467.

Correns, C. W., 1956, The geochemistry of the halogens, in V1 of Ahrens, L. H. and others, eds., Physics and Chemistry of the Earth: New York, McGrawHill, p. 181-233.

Cox, D. C., 1954, Shape of the mixing curve in a Ghyben-Herzberg lens : Hawaiian Acad. Sci. Proc., 29th ann. mtg., p. 9-10.

Dietz, R. S., and Menard, H. W., 1953, Hawaiian swell, deep and arch, and subsidence of the Hawaiian Islands ; Jour. Geology, v. 61, p. 99-113.

Eriksson, Erik, 1957, The chemical composition of Hawaiian rainfall : Tellus, v. 9, p. 509-520.

Glover, R. E., 1959, The pattern of fresh-water flow in a coastal aquifer: Jour. Geophys. Research, v. 64, p. 457-459.

Goldberg, E. D., and Arrhenius, G. O. S., 1958, Chemistry of Pacific pelagic sediments : Geochim. et Cosmochim, Acta; v. 13, p. 158-212.

Hamilton, E. L., 1957, Marine geology of the southern Hawailan Ridge: Geol. Soc. America Bull, v. 68, p. 1011-1026.

Herzberg, Alexander, 1901, die Wasserversorgung einiger Nordeebäder: Jour. f. Gasbelechlung U. Wasserversorgung, Jarg. 44, Munich.

Honolulu Board of Water Supply, 1939, Seventh Biennial Report, 1937-1938: Honolulu Board of Water Supply, $226 \mathrm{p}$.

Hubbert, M. K., 1940, The theory of ground-water motion: Jour. Geology, v. 48, p. 785-944.

Jordan, H. V., and Reisenauer, H. M., 1957, Sulfur and soil fertility, in Soil, the Yearbook of Agriculture, 1957: U.S. Dept. of Agriculture, p. 107-111.

Keith, M. L., and Degens, E. T., 1959, Geochemical indicators of marine and fresh-water sediments, in Abelson, P.H., ed., Researches in Geochemistry : New York, John Wiley and Sons, p. 38-61.

Krauskopf, K. B., 1956, Dissolution and precipitation of silica at low temperatures : Geochim. et Cosmochim, Acta, v. 10, p. 1-26.

Kuroda, P. K., and Sandell, E. B., 1953, Chlorine in igneous rocks: Geol. Soc. America Bull., v. 64, p. 879-896. 
Mink, J. F., 1960, Distribution pattern of rainfall in the leeward Koolau Mountains, Oahu, Hawaii: Jour. Geophys. Research, v. 65, no. 9, p. 2869-2876.

Palmer, H. S., 1927, The geology of the Honolulu artesian system: Honolulu Sewer and Water Comm. Rept., Supp., 68 p.

1955, Geomorphic contrasts within the Koolau Range of Oahu, Hawaii : Pacific Sci., v. 9, p. 304-317.

- 1957, Origin and diffusion of the Herzberg principle with especial reference to Hawaii : Pacific Sci., v. 11, p. 181-189.

Perlmutter, N. M., Geraghty, J. J., and Upson, J. E., 1959, The relation between fresh and salty ground water in southern Nassau and southeastern Queens, Long Island, New York: Econ. Geology, v. 54, p. 416-435.

Rankama, Kalervo, and Sakama, T. G., 1950, Geochemistry: Chicago Univ. Press, 912 p.

Schuyler, J. D., and Allardt, G. F., 1889, Report on the water supply for irrigation of the Honouliuli and Kahuku Ranches: Oakland, Calif., Jordan and Arnold Printers, $32 \mathrm{p}$.

Seckel, G. R., 1955, Hawaiian offshore waters Sept. 1952-Aug. 1953, Part 7 of Mid-Pacific oceanography: U.S. Fish and Wildlife Service, Special Sci. Rept., Fisheries, no. 164, 195 p.

Stearns, H. T., 1939, Geologic map and guide of Oahu, Hawaii : Hawaii Div. Hzdrography Bull. 2, 75 p.

Stearns, H. T., and Vaksvik, K. N., 1935, Geology and ground-water resources of the island of Oahu, Hawali : Hawaii Div. Hydrography, Bull. 1, 479 p.

1938, Records of the drilled wells of Oahu, Hawaii : Hawaii Div. Hydrography Bull. 4, 213 p.

Stearns, H. T., and Macdonald, G. A., 1940, Supplement to the geology and ground-water resources of the island of Oahu, Hawaii : Hawaii Div. Hydrography Bull. 5, $164 \mathrm{p}$.

1942, Geology and ground-water resources of the island of Maui, Hawaii : Hawaii Div. Hydrography Bull. 7, 344 p.

Sverdrup, H. V., Johnson, M. W., and Fleming, R. H., 1946, The oceans, their physics, chemistry and general biology : New York, Prentice-Hall, $1087 \mathrm{p}$.

Swartz, J.H., 1940, Resistivity survey of Schofield plateau : Hawaii Div. Hydrography Bull. 5, p. 57-59.

1958, Geothermal measurements on Eniwetok and Bikini Atolls: U.S. Geol. Survey Prof. Paper 260-U, p. 711-741.

Theis, C. V., 1935, The relation between lowering of the piezometric surface and the rate and duration of discharge of a well using ground-water storage: Am. Geophys. Union Trans., 16 Ann. Mtg., pt. 2, p. 519-524.

U.S. Public Health Service, 1962, Drinking water standards : Federal Register, Mar. 6, p. 2152-2155.

U.S. Salinity Laboratory Staff, 1954, Diagnosis and improvement of saline and alkali soils : U.S. Dept. Agriculture Handb. no. 60, 160 p.

Visher, F. N., and Mink, J. F., 1960, Summary of preliminary findings in groundwater studies of southern Oahu, Hawaii : U.S. Geol. Survey Circ. 435, 16 p.

Wentworth, C. K., 1926, Pyroclastic geology of Oahu: Bernice P. Bishop Mus. Bull. 30, $121 \mathrm{p}$.

1947, Factors in the behavior of ground water in a Ghyben-Herzberg system : Paciflc Sci., v. 1, p. 172-184.

1948, Growth of the Ghyben-Herzberg transition zone under a rinsing hypothesis : Am. Geophys. Union Trans., v. 29, p. 97-98. 
1951, Geology and ground-water resources of the Honolulu-Pearl Harbor area, Oahu, Hawaii : Honolulu Board of Water Supply, $111 \mathrm{p}$.

Wentworth, C. K., and Winchell, Horace, 1947, Koolau basalt series, Oahu, Hawaii : Geol. Soc. America Bull., v. 58, p. 49-78.

Wentworth, C. K., and Macdonald, G. A., 1953, Structure and forms of basaltic rocks in Hawaii : U.S. Geol. Survey Bull. 994, 98 p.

Wentworth, C. K., Mason, A. C., and Davis, D. A., 1955, Salt-water encroachment as induced by sea-level excavation on Angaur Island: Econ. Geology, v. 50, p. 669-680.

White, D. E., 1957, Magmatic, connate and metamorphic waters: Geol. Soc. America Bull., v. 68, p. 1659-1682.

White, D. E., Brannock, W. W., and Murata, K. J., 1956, Silica in hot springs waters: Geochim, et Cosmochim. Acta, v. 10, p. 27-59.

Woodcock, A. H., and Blanchard, D. C., 1955, Tests of salt nuclei hypothesis of rain formation: Tellus, v. 7, p. $437-447$.

Yeh, T. C., Wallen, C. C., and Carson, J. E., 1951, A study of rainfall over Oahu, in On the rainfall of Oahu: Am. Meteorol. Soc., Meteorol. Mon., v. 1, no. 3, p. 34-46. 


\section{INDEX}

[Major references are in italic]

A

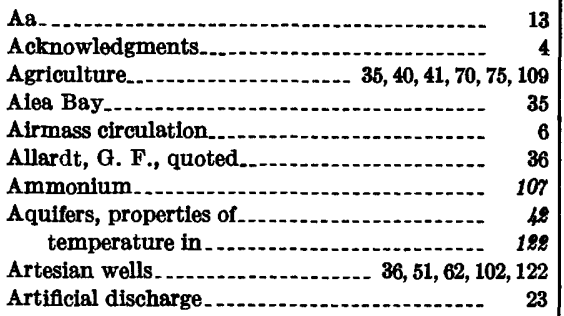

B

Basal aquifer, history of ground-water development.

Basal ground water, general discuasion

Basal tunnels

Basalts, chloride content in

Bibliography

Bicarbonate.

Booth Spring

Boron.

Bromide.

C

Caprock

Chemical composition, expression of

Chloride content, concentration with depth. in basalts

in precipitation

potability defined by

pumping affecting.

Climate

transition zone affected by

Clinker beds

Coastal plain

Coefficient of storage, defined

Cyclonic circulation

\section{D}

Deltas

Dike water, chemical composition of

Dikes

Dissolved solids, analyses of

origins of

sources of.

Drainage

\section{$\mathbf{E}$}

Economic development

Ewa
F

Page

Fertilizers

Flood water, artiflcial recharge of........... 72

Fluoride. . .

Fresh-water lens............................... 18

G

Geochemical cycle.......- 78

Geography .............

Geology

Geothermal gradient ....................... 118, 126

Ground water, basal........................ 19

changes in

composition of............................... 88

development of

fertllizer salts affecting. ...................... 73

fluctuations in levels...................... 44

general discussion. ....................... 17

high-level................................... 18

in caprock

modes of occurrence..................... 18

movement of............................ \$4

perched........................... 18, 88, 90,92

quality of...................................... 74

quantity available......................... 70

source of......... 32

temperature of...................................... 118

utilization of ........................... 69,74

Ground-water development, general discussion............................. 28

Ground-water discharge, general discussion... $\$ \$ 4$

Halawa shaft_...

Halawa Stream ..........

Head, effect of lowering......................

factors influencing......................... 32

maximum regional....................... 49

Herz berg lens, formula for................. 18

Herring Springs............................. 121

Hilo

Historical geology ......................... 11

37 Honolulu ........................................ 46

91 Honolulu Plantation Co. shaft $\ldots . . . . . . . . . . . . .63$

Honolulu Volcanic Beries............... 13, 15, 86, 92

Honouliuli Stream.............................. 35

81 Hydrologic cycle $\ldots . . . . . . .61,118$

Interface, pumping affecting $\ldots$

Intruded sea water, composition of.......... temperature of 


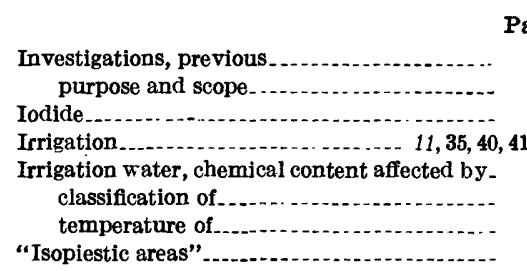

\section{$\mathbf{K}$}

Kaala

Kahuauai Springs

Kaimuki pump

Kalauao Springs

Kalauoopu Springs.

Kalihi shaft

Kalihi Stream.

Ralihi Valley

Kamehameha Highway

Kaukonahua Stream

Kipapa Stream

Koolau Range

$81,83,88,110$

$3,5,12,81,83,119,12$

Koolau Volcanic Series.... 18, 32, 74, 86, 89, 91, 94, 114

Koolau Volcano

\section{L}

Laterization

Lava fiows.

Lava tubes

Lithium

Location, of area.

Lokokukona Springs.

Lualualei Valley

$\mathbf{M}$

Makiki Springs 92,121

Marine muds

Maut

Mauna Kea

Moanalua Stream

Manoa Stream

Moiliili caprock

........

\section{1}

Py

Population .................................. 11

Potassium ................................... 110

Precipitation ................... 7, 32, 44, 79, 119

Pumping, effects of

history of

Puukapu Springs............................ 41

Pyroclastic rocks .............

Rainfall, See Precipitation.

Rainwater, terrestrial environment affecting.-

Recharge, from irrigation water............ 51 sources of ............................... 32

Recharge, temperature of

Recommendations......................... $r_{1}$

Relative humidity ....................... 6

Relative mobility, defined................. 94

\section{S}

chofield plateau........................ 3, 5,18

Schuyler, J. D., quoted.................. 36

Sea water, general discussion................ $\quad 85$

intrusion of............................... 95

temperature gradient in ................ $\quad 126$

See also Intruded sea water.

Sedimentary deposits...................... 15

Sedimentation

Sewage, effect on ground water............ 73

Shield volcanoes........................... 12

Silica_._.

Sodium-absorption-ratio, formula for ....... 76

Soils......................... 17, 76, 77, 87, 111, 120

Specific conductance, defined................ 74

Springs, description of ................. 40

head affecting fiow from.................. 38

saline content of ...................... 56

temperatures of ........................... 123

See also particular spring.

Standard aquifer-test procedure .............. 49

Stream water, chemical composition of....... $\quad 89$

Sugarcane, use of water by . . . . .

Sulfate

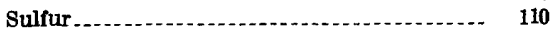

Summary . . . .

Nitrate-........... 108,114

Nitrogen . ................................... 109

Nuuanu Stream.

urface water, composition of

Swamps.............. 41,71

Orographic rainfall.

0

9,119

$\mathbf{P}$

Pahoehoe

Palolo Stream

Pauoa Stream.

Pearl City Peninsula.

Pearl Harbor

Pearl Harbor springs, discharge from ...... 38, 69, 70

history of use............................ 35

transition zone at

See also particular spring.

Perched ground water $18,88,90,92$

Permeability, ground-water movement affected by

Phosphate.

Temperature, atmospheric................. 6,119

basal aquifer........................... 122

intruded saline water................... 124

Temperatures, recharge water ............. 120

Terrestrial environment, solution from...... 92

Tides, transition zone affected by ........... 48

Transition zone, behavior of evolution of................................ 48

general discussion ........................ 20,45

Transmissibility, defined...................... 48

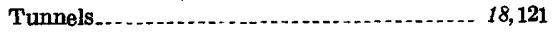

\section{V}




\section{W}

Page

32, 56, 70, 108

Waiahole Ditch Tunnel.

Waianae Range.

Waianae tunnel.

Waianae Valley.

$3,6,119,122$

Waianae Volcanic Series

Waianae volcano

Waiau Springs.

Waiaw a shaft.

Waiawa Springs

Waikele Springs
Waikele Stream

Page

-... 35, 41

Waimano Springs........ 35, 38, 40, 59, 60, 62, 63, 124

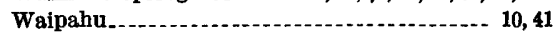

Wells, general discussion.................. 29 history of ......................... 48

Wind speed, mean ........................... 6 